DANY MICHELL ANDRADE CENTENO

\title{
ANÁLISE MICROESTRUTURAL DE JUNTA BRASADA DE AÇO INOXIDÁVEL DUPLEX UNS S32101, UNS S32304, UNS S32750 E UNS S32707 COM METAL DE ADIÇÃO A BASE DE NÍQUEL.
}

\author{
Dissertação apresentada à Escola \\ Politécnica da Universidade de São \\ Paulo, para obtenção do Título de \\ Mestre em Ciências.
}

São Paulo 
DANY MICHELL ANDRADE CENTENO

\section{ANÁLISE MICROESTRUTURAL DE JUNTA BRASADA DE AÇO INOXIDÁVEL DUPLEX UNS S32101, UNS S32304, UNS S32750 E UNS S32707 COM METAL DE ADIÇÃO A BASE DE NÍQUEL.}

Dissertação apresentada à Escola Politécnica da Universidade de São Paulo, para obtenção do Título de Mestre em Ciências.

Área de concentração:

Engenharia Metalúrgica e de Materiais.

Orientador:

Prof. Dr. Sérgio Duarte Brandi. 
Este exemplar foi revisado e corrigido em relação à versão original, sob responsabilidade única do autor e com a anuência de seu orientador.

São Paulo, de novembro de 2013.

Assinatura do autor

Assinatura do orientador

FICHA CATALOGRÁFICA

Centeno, Dany Michell Andrade

Análise microestrutural de junta brasada de aço inoxidável duplex UNS S32101, UNS S32304, UNS S32750 e UNS S32707 com metal de adição a base de níquel / D.M.A. Centeno. -- versão corr. -- São Paulo, 2013.

128p.

Dissertação (Mestrado) - Escola Politécnica da Universidade de São Paulo. Departamento de Engenharia Metalúrgica e de Materiais.

1.Soldagem 2.Brasagem 3.Aço inoxidável duplex I.Universidade de São Paulo. Escola Politécnica. Departamento de Engenharia Metalúrgica e de Materiais II. t. 
"A ciência é composta de erros que, por sua vez, são passos em direção à verdade".

Júlio Verne 


\section{Dedicatória}

A meu anjo amado, que me deslumbrou a cada ínfimo momento com tanto amor; sempre irradiando minha senda de imensurável alegria, minha avó Nelly (IN MEMORIAM).

A minha mãe Laura, sem ela desvaneço. 


\section{Agradecimentos}

A Deus por fortalecer e guiar cada passo que dou.

Ao meu orientador, prof. Dr. Sérgio Duarte Brandi, pela generosidade, paciência e constante ajuda oferecida durante todo este tempo.

A minha adorada mãe, Laura Centeno Calderón, que sempre me mostrou que nossa maior fortaleza vem dos nossos sacrifícios e conquistas.

Aos meus queridos irmãos, Sheyla e Erik, por nunca deixar de acreditar em mim, pois sua confiança me enche de coragem a cada dia.

A meu avô, Augusto Centeno Paredes, por segurar minha mão durante tanto tempo.

Aos meus tios, Jilmar e Vladimiro Centeno, por me ensinar a enfrentar qualquer dificuldade sem temor de fracasso.

A Clelia Rodrigues pela compreensão, amor e companheirismo.

Aos meus amigos Erick Vargas, Erick Portugal, Dennis Roldan, Ligia Cateriano, Gerby Rondan, Maritza Chirinos, Marvin Chambi, por compartilhar tantos momentos de alegria.

Aos meus amigos do departamento, Alan Barros, Adriano Almeida, Anderson Ariza, Luis Varela, Luis Espitia, Mario Gonzales, Rafael Rocha por me fazer sentir como em casa.

Ao Vinicius Freire pelo enorme apoio na realização das análises e treinamento desinteressado que me ofereceu.

Aos meus colegas do laboratório, André, Anderson, Jaime e Luis pela colaboração na realização do meu trabalho.

À Coordenação de Aperfeiçoamento de Pessoal de Nível Superior (CAPES), pela concessão de bolsa de estudo.

À empresa BTM Brasagem e Tratamentos em metal, em especial a Clovis Carvalho Jr., pela disposição e comprometimento na realização da parte experimental deste trabalho. 
A todos aqueles que estiveram direitamente ou indiretamente envolvidos na correta execução deste trabalho. 


\section{CURRICULUM VITAE}

\section{DANY MICHELL ANDRADE CENTENO}

\section{Formação}

Universidade Nacional de São Agustín de Arequipa-Perú

Engenheiro de Materiais (Junho do 2008)

\section{Trabalhos completos publicados em anais de congressos}

CENTENO, D. M. A.; BRANDI, S. D. Análise microestrurural de junta brasada de aço inoxidável duplex UNS S32101. In: XXXVI Congresso Nacional de Soldagem (CONSOLDA); Associação Brasileira de Soldagem (ABS), 2010, Recife, PB. XXXVI Congresso Nacional de Soldagem (CONSOLDA); Associação Brasileira de Soldagem (ABS), 2010. p. CT-52.

CENTENO, D. M. A.; CLOVIS, C. J.; BRANDI, S. D. Caracterização metalográfica de junta brasada de aço inoxidável duplex UNS S32304 In: 66o. Congresso Anual da ABM, 2011, São Paulo. 66o. Congresso Anual da ABM. São Paulo : Associação Brasileira de Metalurgia e Materiais, 2011.

CENTENO, D. M. A. ; CARVALHO JR, C. ; BRANDI, S.D. . Brazeability of UNS S 32101 and UNS S2304 lean duplex stainless steels. In: Trends in Welding Research 2012, 2013, Chicago. Trends in Welding Research 2012: Proceedings of the 9th International Conference. Miami: ASM International, 2012. p. 814-822.

CENTENO, D. M. A.; BRANDI, S. D. Comportamiento microestructural de juntas soldadas por soldadura fuerte de acero inoxidable dúplex de baja aleación usando ni-p como metal de aporte. In: II Simposium de aceros inoxidables, 2012, Arequipa, Perú.

Centeno, D. M. A. ; BRANDI, S. D. . Comparação de técnicas de identificação em junta brasada de aço de inoxidável duplex UNS S32101. In: 680 Congresso Anual da ABM, 2013, Belo Horizonte, MG. 68o Congresso Anual da ABM. São Paulo : Associação Brasileira de Metalurgia e Materiais, 2013. v. único. p. 4073-408 


\section{SUMÁRIO}

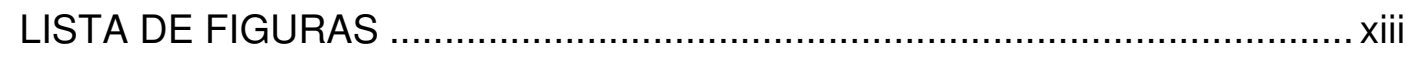

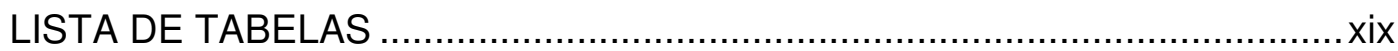

LISTA DE SÍMBOLOS E ABREVIATURAS .......................................... xxii

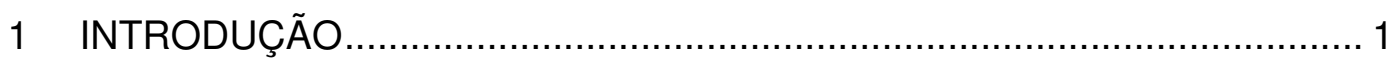

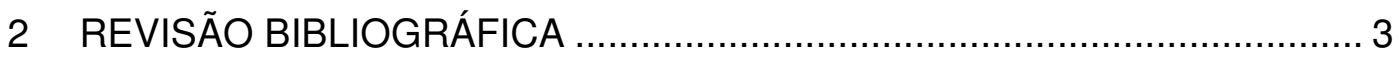

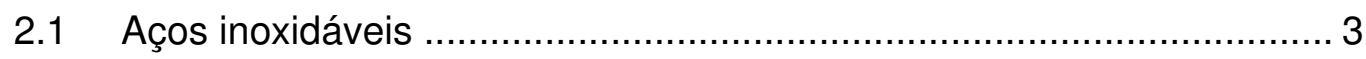

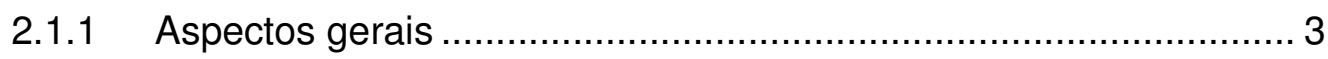

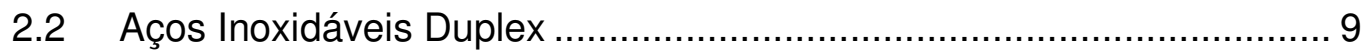

2.2.1 Aspectos gerais dos aços inoxidáveis duplex......................... 10

2.2.2 Tipos de aços inoxidáveis duplex ..................................... 11

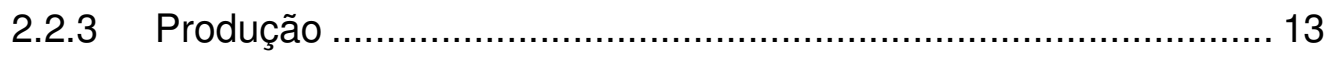

2.2.4 Propriedades mecânicas dos aços inoxidáveis duplex ................ 14

2.2.5 Propriedades físicas dos aços inoxidáveis duplex ..................... 15

2.2.6 Resistência à corrosão dos aços inoxidáveis duplex ................... 16

2.2.7 Soldabilidade dos aços inoxidáveis duplex............................ 17

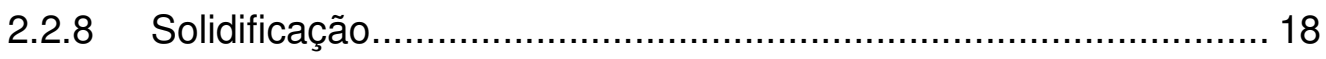

2.2.9 Precipitação de fases nos aços inoxidáveis duplex ..................... 18

2.3 Processo de junção............................................................. 24

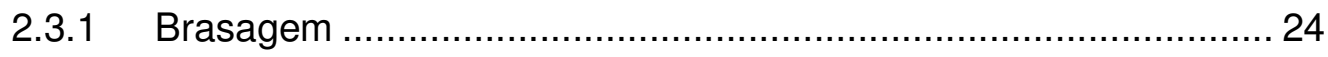

2.3.2 Principais métodos de brasagem...................................... 25

2.3.2.1 Brasagem por chama ............................................... 26

2.3.2.2 Brasagem por indução .............................................. 26

2.3.2.3 Brasagem em forno ............................................... 27

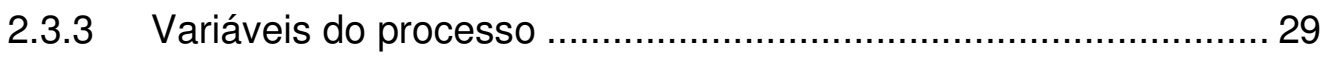

2.3.3.1 Tensões superficiais e ângulo de contato .............................29

2.3.3.2 Espalhamento ..................................................... 33 
2.3.3.3 Capilaridade 33

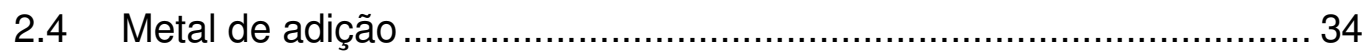

2.4.1 Metais de adição a base de níquel ............................................. 35

2.4.1.1 Efeito dos elementos de liga nas adições à base de níquel para

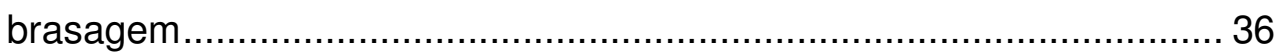

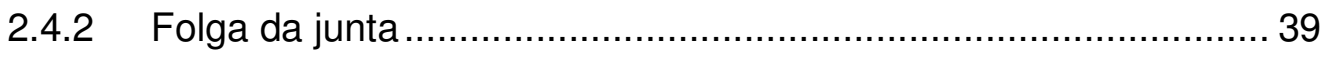

2.4.3 Atmosferas para brasagem ...................................................... 41

2.5 Microestrutura de junta brasada .................................................... 43

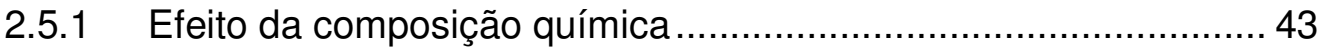

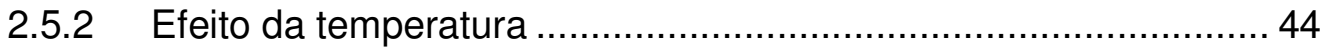

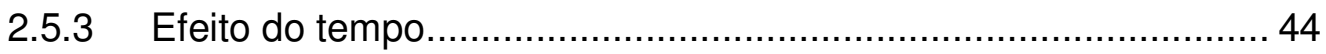

2.5.4 Efeito da folga da junta .............................................................. 45

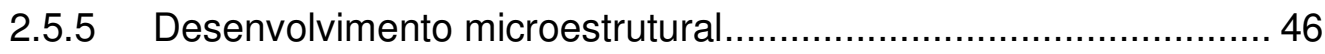

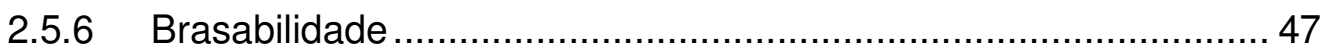

3 OBJETIVOS

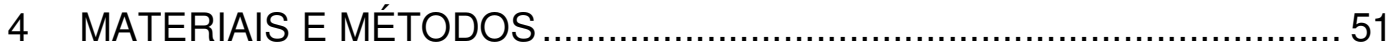

4.1 Metal base

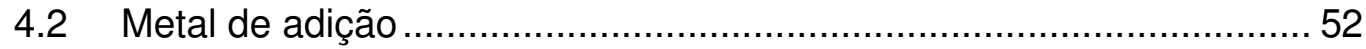

4.3 Equipamento para brasagem ...................................................... 52

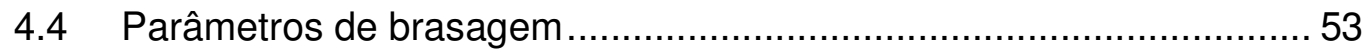

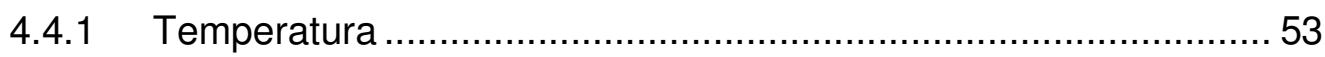

4.4.2 Velocidade de esteira ............................................................. 54

4.4.2.1 Condições de processo ………................................................. 54

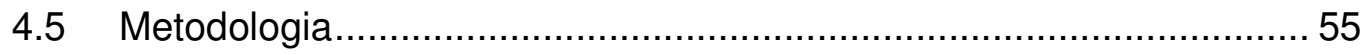

4.5.1 Preparação dos corpos de prova .................................................. 55

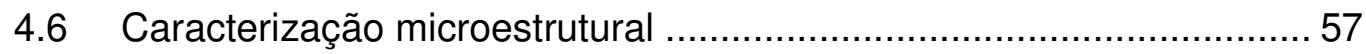

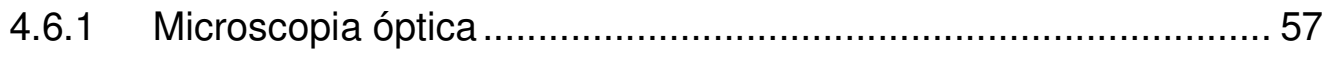


4.6.2 Microscopia eletrônica ............................................................. 58

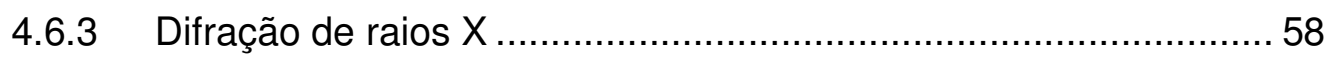

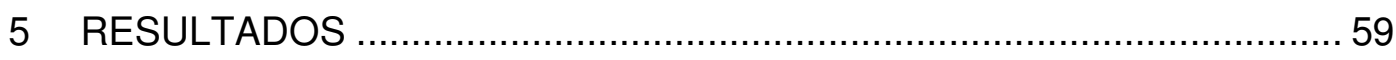

5.1 Análise Microestrutural.................................................................. 59

5.1.1 Microscopia Óptica .............................................................. 59

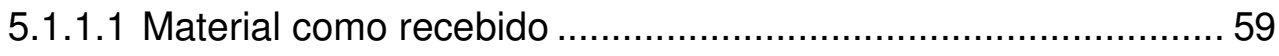

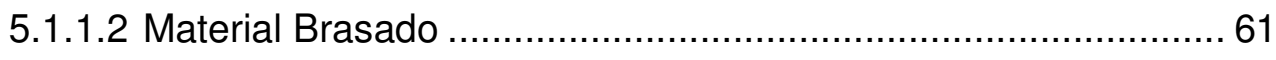

5.1.2 Microscopia Eletrônica de Varredura (MEV) ............................... 77

5.1.2.1 Condição 1: tempo de $32 \mathrm{~min}$ e $0,5 \mathrm{~mm}$ de folga ....................... 77

5.1.2.2 Condição 2: tempo de $32 \mathrm{~min}$ e $0,3 \mathrm{~mm}$ de folga ...................... 80

5.1.2.3 Condição 3: tempo de $32 \mathrm{~min}$ e $0,0 \mathrm{~mm}$ de folga ...................... 83

5.1.2.4 Condição 4: tempo de $12 \mathrm{~min}$ e $0,5 \mathrm{~mm}$ de folga ....................... 86

5.1.2.5 Condição 5: tempo de $12 \mathrm{~min}$ e $0,3 \mathrm{~mm}$ de folga ...................... 90

5.1.2.6 Condição 6: tempo de $12 \mathrm{~min}$ e $0,0 \mathrm{~mm}$ de folga ....................... 92

5.1.3 Caracterização microestrutural da junta brasada por difração de

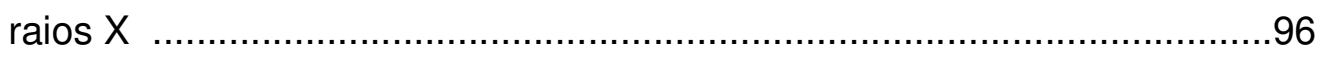

5.2 Medida da folga ideal nos corpos-de-prova estudados..................... 103

5.3 Determinação da composição química da junta brasada................... 105

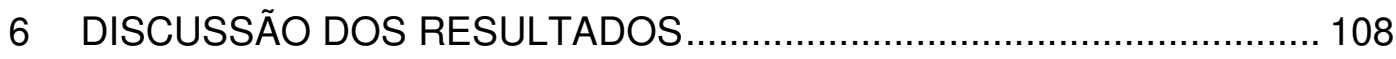

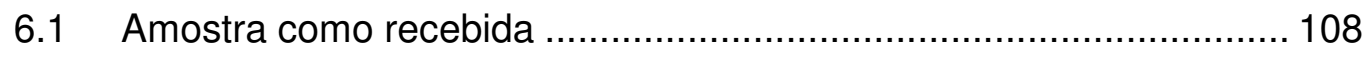

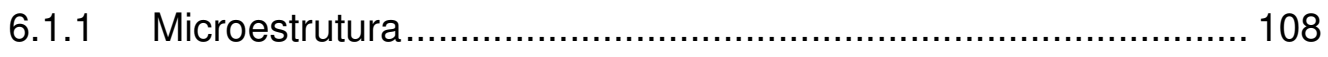

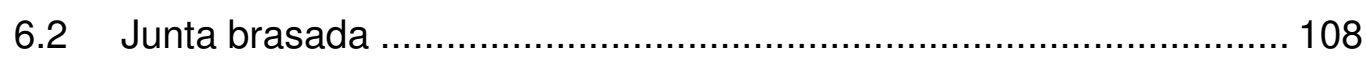

6.2.1 Caracterização microestrutural ............................................... 108

6.2.1.1 Efeito do tipo de AID no desenvolvimento da microestrutura da

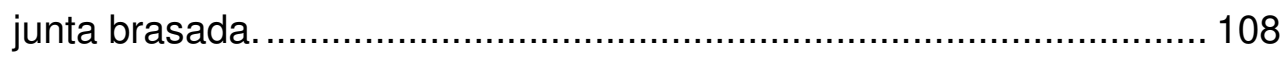

6.2.1.2 Efeito da folga no desenvolvimento da microestrutura da junta brasada... 
6.2.1.3 Efeito do tempo no desenvolvimento da microestrutura da junta

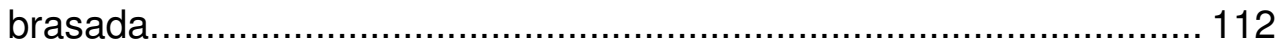

6.2.1.4 Identificação das fases por EDS e Difração de Raios X........... 113

6.2.1.5 Brasabilidade dos aços inoxidáveis duplex ............................ 118

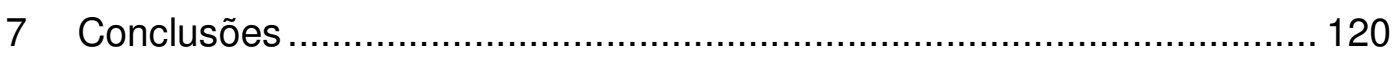

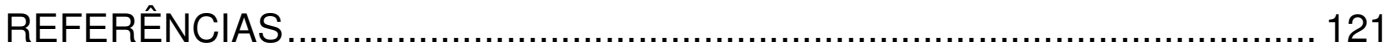




\section{LISTA DE FIGURAS}

Figura 2.1 - Efeito do teor de cromo sobre o campo austenítico[5] .................. 4

Figura 2.2 - Classificação dos aços inoxidáveis[6]......................................... 5

Figura 2.3 - Diagrama de fase Fe-Cr [6] ............................................... 6

Figura 2.4 - Análise químico no desenvolvimento dos AID[14]...................... 13

Figura 2.5 - Precipitação de fases secundárias nos aços inoxidáveis duplex [26].

Figura 2.6 - Diagrama de formação de fase sigma nos aços inoxidáveis duplex seguindo uma decomposição eutetóide[27]. 20

Figura 2.7 - Representação esquemática da precipitação e evolução microestrutural dos carbonetos nos aços inoxidáveis duplex [32] .................. 22

Figura 2.8 - Classificação dos Processos de Brasagem[37].......................... 25

Figura 2.9 - Esquema de um forno contínuo para brasagem (Adaptado de [37]) 28

Figura 2.10 - Forças de atração entre partículas da superfície e do interior de um líquido, para uma interface plana líquido-vapor.

Figura 2.11 - Esquema das interfaces presentes em uma gota de um líquido em um substrato sólido circuncidado por um gás com as respectivas tensões superficiais[37]. 30

Figura 2.12 - Ângulo de contato $\theta$ para uma gota líquida sobre um substrato sólido: (a) $>90^{\circ}$, (b) $<90^{\circ}$, e (c) $\theta=90^{\circ}[42]$. 30

Figura 2.13 - Seção de diagrama de fases $\mathrm{Ni}$ - B [51]. 37

Figura 2.14 - Esquema da presença de folga ideal em função de resistência ao cisalhamento da junta[37] 40

Figura 2.15 - Relação entre oxidação e redução de óxido em função do ponto de orvalho e da temperatura [37].

Figura 2.16 - Sequência de desenvolvimento da microestrutura na junta durante a brasagem $[55,60]$. 47

Figura 2.17 - Relação entre os diferentes fatores que definem a brasabilidade [69].

Figura 2.18 - relação entre a folga da junta e resistência mecânica segundo o estado ideal e fora do ideal [66].

Figura 4.1 - Detalhe do painel de controle do forno durante a brasagem. 
Figura 4.2 - Esquema de desenvolvimento das condições de brasagem........ 55

Figura 4.3 - Esquema da montagem dos corpos de prova............................. 56

Figura 4.4 - Vistas isométricas do corpo de prova , a) montado b) cortado c) seção de análise. 56

Figura 5.1 - Micrografias 3D dos AID's no estado como-recebido. a) UNS S32101, b) UNS S32304, c) UNS S32750 e d) UNS S32707. 60

Figura 5.2 - Microestrutura da junta brasada obtida por microscopia óptica do AID. UNS S32101 para um tamanho de folga de $0,5 \mathrm{~mm}$. 62

Figura 5.3 - Microestrutura da junta brasada obtida por microscopia óptica do AID. UNS S32304 para um tamanho de folga de $0,5 \mathrm{~mm}$. 62

Figura 5.4 - Microestrutura da junta brasada obtida por microscopia óptica do AID. UNS S32750 para um tamanho de folga de $0,5 \mathrm{~mm}$. 63

Figura 5.5 - Microestrutura da junta brasada obtida por microscopia óptica do AID. UNS S32707 para um tamanho de folga de $0,5 \mathrm{~mm}$. 63

Figura 5.6 - Microestrutura da junta brasada obtida por microscopia óptica do AID. UNS S32101 para um tamanho de folga de $0,3 \mathrm{~mm}$. 65

Figura 5.7 - Microestrutura da junta brasada obtida por microscopia óptica do AID. UNS S32304 para um tamanho de folga de $0,3 \mathrm{~mm}$. 65

Figura 5.8 - Microestrutura da junta brasada obtida por microscopia óptica do AID. UNS S32750 para um tamanho de folga de $0,3 \mathrm{~mm}$. 66

Figura 5.9 - Microestrutura da junta brasada obtida por microscopia óptica do AID. UNS S32707 para um tamanho de folga de $0,3 \mathrm{~mm}$. 66

Figura 5.10 - Microestrutura da junta brasada obtida por microscopia óptica do AID. UNS S32101 para um tamanho de folga de $0,0 \mathrm{~mm}$. 67

Figura 5.11 - Microestrutura da junta brasada obtida por microscopia óptica do AID. UNS S32304 para um tamanho de folga de $0,0 \mathrm{~mm}$. 68

Figura 5.12 - Microestrutura da junta brasada obtida por microscopia óptica do AID. UNS S32750 para um tamanho de folga de $0,0 \mathrm{~mm}$. 68

Figura 5.13 - Microestrutura da junta brasada obtida por microscopia óptica do AID. UNS S32707 para um tamanho de folga de $0,0 \mathrm{~mm}$. 69

Figura 5.14 - Microestrutura da junta brasada obtida por microscopia óptica do AID. UNS S32101 para um tamanho de folga de $0,5 \mathrm{~mm}$. 70

Figura 5.15 - Microestrutura da junta brasada obtida por microscopia óptica do AID. UNS S32304 para um tamanho de folga de $0,5 \mathrm{~mm}$ 70 
Figura 5.16 - Microestrutura da junta brasada obtida por microscopia óptica do AID. UNS S32750 para um tamanho de folga de $0,5 \mathrm{~mm}$. 71

Figura 5.17 - Microestrutura da junta brasada obtida por microscopia óptica do AID. UNS S32707 para um tamanho de folga de 0,5 $\mathrm{mm}$. 71

Figura 5.18 - Microestrutura da junta brasada obtida por microscopia óptica do AID. UNS S32101 para um tamanho de folga de 0,3 $\mathrm{mm}$. 72

Figura 5.19 - Microestrutura da junta brasada obtida por microscopia óptica do AID. UNS S32304 para um tamanho de folga de 0,3 $\mathrm{mm}$. 73

Figura 5.20 - Microestrutura da junta brasada obtida por microscopia óptica do AID. UNS S32750 para um tamanho de folga de 0,3 $\mathrm{mm}$. 73

Figura 5.21 - Microestrutura da junta brasada obtida por microscopia óptica do AID. UNS S3707 74

Figura 5.22 - Microestrutura da junta brasada obtida por microscopia óptica do AID. UNS S32101 para um tamanho de folga de $0,0 \mathrm{~mm}$ 75

Figura 5.23 - Microestrutura da junta brasada obtida por microscopia óptica do AID. UNS S32304 para um tamanho de folga de 0,0 $\mathrm{mm}$. 75

Figura 5.24 - Microestrutura da junta brasada obtida por microscopia óptica do AID. UNS S32750 para um tamanho de folga de $0,0 \mathrm{~mm}$........................... 76 Figura 5.25 - Microestrutura da junta brasada obtida por microscopia óptica do AID. UNS S32707 para um tamanho de folga de 0,0 $\mathrm{mm}$. 76

Figura 5.26 - Micrografias por MEV da região da junta brasada do AID UNS S32101. Em a) vista geral e b) ampliação região interna. 78

Figura 5.27 - Micrografias por MEV da região da junta brasada do AID UNS S32304. Em a) vista geral e b) ampliação região interna. 79

Figura 5.28 - Micrografias por MEV da região da junta brasada do AID UNS S32750. Em a) vista geral e b) ampliação região interna. 79

Figura 5.29 - Micrografias por MEV da região da junta brasada do AID UNS S32707. Em a) vista geral e b) ampliação região interna. 80

Figura 5.30 - Micrografias por MEV da região da junta brasada do AID UNS S32101. Em a) vista geral e b) ampliação região interna.

Figura 5.31 - Micrografias por MEV da região da junta brasada do AID UNS S32304. Em a) vista geral e b) ampliação região interna. 82

Figura 5.32 - Micrografias por MEV da região da junta brasada do AID UNS S32750. Em a) vista geral e b) ampliação região interna. 82 
Figura 5.33 - Micrografias por MEV da região da junta brasada do AID UNS S32707. Em a) vista geral e b) ampliação região interna. 83

Figura 5.34 - Micrografias por MEV da região da junta brasada do AID UNS S32101. Em a) vista geral e b) ampliação região interna. 84

Figura 5.35 - Micrografias por MEV da região da junta brasada do AID UNS S32304. Em a) vista geral e b) ampliação região interna. 85

Figura 5.36 - Micrografias por MEV da região da junta brasada do AID UNS S32750. Em a) vista geral e b) ampliação região interna. 85

Figura 5.37 - Micrografias por MEV da região da junta brasada do AID UNS S32707. Em a) vista geral e b) ampliação região interna. 86

Figura 5.38 - Micrografias por MEV da região da junta brasada do AID UNS S32101. Em a) vista geral e b) ampliação região interna. 87

Figura 5.39 - Micrografias por MEV da região da junta brasada do AID UNS S32304. Em a) vista geral e b) ampliação região interna. 88

Figura 5.40 - Micrografias por MEV da região da junta brasada do AID UNS S32750. Em a) vista geral e b) ampliação região interna. 88

Figura 5.41 - Micrografias por MEV da região da junta brasada do AID UNS S32707. Em a) vista geral e b) ampliação região interna. 89

Figura 5.42 - Micrografias por MEV da região da junta brasada do AID UNS S32101. Em a) vista geral e b) ampliação região interna. 90

Figura 5.43 - Micrografias por MEV da região da junta brasada do AID UNS S32304. Em a) vista geral e b) ampliação região interna.

Figura 5.44 - Micrografias por MEV da região da junta brasada do AID UNS S32750. Em a) vista geral e b) ampliação região interna. 91

Figura 5.45 - Micrografias por MEV da região da junta brasada do AID UNS S32707. Em a) vista geral e b) ampliação região interna. 92

Figura 5.46 - Micrografias por MEV da região da junta brasada do AID UNS S32101. Em a) vista geral e b) ampliação região interna. 93

Figura 5.47 - Micrografias por MEV da região da junta brasada do AID UNS S32304. Em a) vista geral e b) ampliação região interna. 93

Figura 5.48 - Micrografias por MEV da região da junta brasada do AID UNS S32750. Em a) vista geral e b) ampliação região interna. 94

Figura 5.49 - Micrografias por MEV da região da junta brasada do AID UNS S32707. Em a) vista e geral e b) ampliação região interna. 95 
Figura 5.50 - Identificação de fases na junta brasada com suporte do programa X'Pert High Score Plus. 96

Figura 5.51 - Difratograma da junta brasada do AID UNS S32101 ............... 97

Figura 5.52 - Difratograma da junta brasada do AID UNS S32304 ................ 98

Figura 5.53 - Difratograma da junta brasada do AID UNS S32750 ................ 99

Figura 5.54 - Difratograma da junta brasada do AID UNS S32707.............. 100

Figura 5.55 - Medida da folga ideal no ensaio da cunha para o AID UNS S32101 nos tempos de brasagem de 12 e 32 min..................................... 103

Figura 5.56 - Medida da folga ideal no ensaio da cunha para o AID UNS S32304 nos tempos de brasagem de 12 e 32 min...................................... 104

Figura 5.57 - Medida da folga ideal no ensaio da cunha para o AID UNS S32750 nos tempos de brasagem de 12 e 32 min...................................... 104

Figura 5.58 - Medida da folga ideal no ensaio da cunha para o AID UNS S32707 nos tempos de brasagem de 12 e 32 min...................................... 104

Figura 5.59 - Áreas de análise química via EDS nos AID, (a) aertura de 0,3 mm

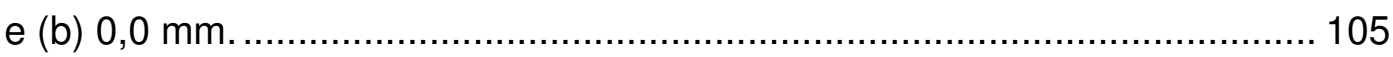

Figura 5.60 - Variação dos elementos de liga após brasagem para o AID UNS

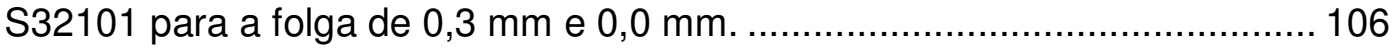

Figura 5.61 - Variação dos elementos de liga após brasagem para o AID UNS S32101 para a folga de 0,3 mm e 0,0 mm. ........................................... 106

Figura 6.1 - Gráfico comparativo entre a porcentagem de $\mathrm{Ni}$ entre as fases encontradas na junta brasada da condição 1 ........................................... 110

Figura 6.2 - Gráfico comparativo entre a porcentagem de $\mathrm{Ni}$ entre as fases encontradas na junta brasada da condição 2 . 111

Figura 6.3 - Desenvolvimento da microestrutura brasada em função do tamanho de folga para o aço duplex UNS S32101 e tempo de brasagem de 32 min. (a) Folga de 0,5 mm; (b) folga de 0,3 $\mathrm{mm}$ e (c) folga de 0,0 mm.......... 111 Figura 6.4 - Representação do desenvolvimento microestrutural da solução sólida rica em níquel, $\gamma$-Ni, a partir da interface para duas dimensões de folgas

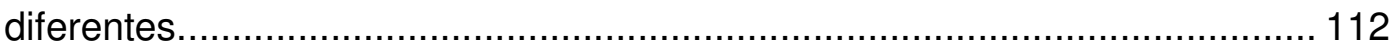

Figura 6.5 - Diagramas de fase. (a) Ni-P e (b) Cr-P. ................................ 114 Figura 6.6 - Microfotografia apresentando fase ternaria $\mathrm{Cr}_{1.2} \mathrm{Ni}_{0.8} \mathrm{P}$ na junta brasada do AID UNS32707................................................................ 116 
Figura 6.7 - Projeção do diagrama ternario Ni-Cr-P via thermocalc para as temperaturas a) $1000^{\circ} \mathrm{C}$;

Figura 6.8 - Desenvolvimento das fases durante o resfriamento................... 118

Figura 6.9 - Micrografias da formação da fase sigma no AID UNS S32707 a) perto da interface da junta e b) no metal base. ........................................ 119 Figura 6.10 - Análise química por EDS da fase identificada da junta brasada para o aço UNS S32750 na interface da junta. 


\section{LISTA DE TABELAS}

Tabela 2.1 - Composição química típica de alguns aços inoxidáveis duplex [8, $10]$. 11

Tabela 2.2 - Propriedades mecânicas dos diferentes aços inoxidáveis duplex segundo a norma ASTM A790[18] 14

Tabela 2.3 - Propriedades físicas dos aços inoxidáveis duplex e outros aços[10].

Tabela 2.4 - Principais fases que podem precipitar nos aços inoxidáveis duplex[24]. 19

Tabela 2.5 - Composição química de metais de adição BNi segundo a norma AWS A5.8-92[49]. 35

Tabela 2.6 - Temperaturas liquidus, solidus e faixa de temperatura recomendada para brasagem de ligas à base de níquel, segundo AWS A5.8-92 [49]. 36

Tabela 2.7 - Efeito dos elementos de liga nas propriedades das adições de níquel para brasagem [50]. 36

Tabela 4.1 - Composição química dos diferentes aços inoxidáveis duplex utilizados. 51

Tabela 4.2 - Composição química do metal de adição. 52

Tabela 4.3 - Distribuição de temperatura no forno durante o ciclo de brasagem.

Tabela 5.1 - Análise química via EDS das fases identificadas na junta brasada do AID UNS S32101. 78

Tabela 5.2 - Análise química via EDS das fases identificadas na junta brasada do AID UNS S32304.

Tabela 5.3 - Análise química via EDS das fases identificadas na junta brasada do AID UNS S32750.

Tabela 5.4 - Análise química via EDS das fases identificadas na junta brasada do AID UNS S32707. 80

Tabela 5.5- Análise química via EDS das fases identificadas na junta brasada do AID UNS S32101.

Tabela 5.6 - Análise química via EDS das fases identificadas na junta brasada do AID UNS S32101. 
Tabela 5.7 - Análise química via EDS das fases identificadas na junta brasada do AID UNS S32750. 83

Tabela 5.8 - Análise química via EDS das fases identificadas na junta brasada do AID UNS S32707. 83

Tabela 5.9 - Análise química via EDS das fases identificadas na junta brasada do AID UNS S32101. 84

Tabela 5.10 - Análise química via EDS das fases identificadas na junta brasada do AID UNS S32101. 85

Tabela 5.11- Análise química via EDS das fases identificadas na junta brasada do AID UNS S32750. 86

Tabela 5.12 - Análise química via EDS das fases identificadas na junta brasada do AID UNS S32707. 86

Tabela 5.13 - Análise química via EDS das fases identificadas na junta

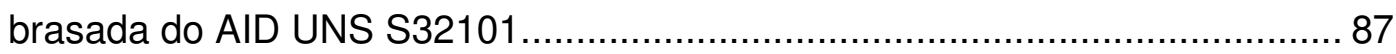

Tabela 5.14 - Análise química via EDS das fases identificadas na junta

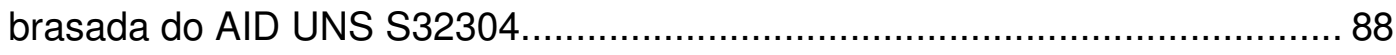

Tabela 5.15 - Análise química via EDS das fases identificadas na junta brasada do AID UNS S32750. 89

Tabela 5.16 - Análise química via EDS das fases identificadas na junta brasada do AID UNS S32707. 89

Tabela 5.17 - Análise química via EDS das fases identificadas na junta brasada do AID UNS S32101. 90

Tabela 5.18 - Análise química via EDS das fases identificadas na junta brasada do AID UNS S32304. 91

Tabela 5.19 - Análise química via EDS das fases identificadas na junta brasada do AID UNS S32750. 92 Tabela 5.20 - Análise química via EDS das fases identificadas na junta brasada do AID UNS S32707. 92

Tabela 5.21- Análise química via EDS das fases identificadas na junta brasada do AID UNS S32101. 93

Tabela 5.22- Análise química via EDS das fases identificadas na junta brasada do AID UNS S32304. 94

Tabela 5.23- Análise química via EDS das fases identificadas na junta brasada do AID UNS S32750. 
Tabela 5.24 - Análise química via EDS das fases identificadas na junta

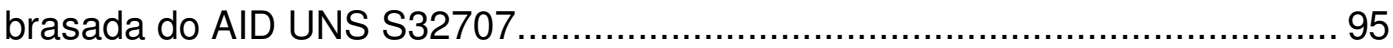

Tabela 5.25 - Identificação das fases presentes na junta brasada do AID UNS S32101.

Tabela 5.26 - Identificação das fases presentes na junta brasada do AID UNS S32304.

Tabela 5.27 - Identificação das fases presentes na junta brasada do AID UNS S32750. 99

Tabela 5.28 - Identificação das fases presentes na junta brasada do AID UNS S32707. 100

Tabela 5.29 - Comparativo entre o parâmetro de rede das fases presentes na junta brasada do AID UNS S32101 e o parâmetro de rede das fichas JCPDS.

Tabela 5.30 - Comparativo entre o parâmetro de rede das fases presentes na junta brasada do AID UNS S32304 e o parâmetro de rede das fichas JCPDS. 101

Tabela 5.31 - Comparativo entre o parâmetro de rede das fases presentes na junta brasada do AID UNS S32750 e o parâmetro de rede das fichas JCPDS. 102

Tabela 5.32 - Comparativo entre o parâmetro de rede das fases presentes na junta brasada do AID UNS S32707 e o parâmetro de rede das fichas JCPDS. 102

Tabela 5.33 - Comparativo da analise química em áreas determinadas da junta brasada para os AID UNS S32101 e UNS S32750................................... 105

Tabela 6.1 - Comparação da relação estequiométrica $[(\mathrm{Ni}+\mathrm{Cr}) / \mathrm{P}]$ e $(\mathrm{Ni} / \mathrm{P})$ das fases formadas na junta brasada para os quatro AID.............................. 115

Tabela 6.2- Fases identificadas via difração de raios $X$ nos quatro AID ........ 115 


\section{LISTA DE SÍMBOLOS E ABREVIATURAS}

\section{DESCRIÇÃO}

a

A

AID

AlHD

AISD

AISI

AOD

ASTM

AWS

BSE

C

$\mathrm{C}_{1}$

CCC

CFC

E

EDS

$\mathrm{F}$

g

$\mathrm{H}$

HB

$\mathrm{HCP}$

Hex

JCPDS

$\mathrm{K}$

MEV

$\mathrm{n}_{1}$
Parâmetro de rede

Área molhada da superfície de contato

Aço inoxidável duplex

Aço inoxidável hiperduplex

Aço inoxidável superduplex

American Iron and steel institute

Argon oxigen decarburization

American Society for Testing and Materials

American Welding Society

"Backscattered electrons" - Elétrons retroespalhados

Parâmetro de rede

Raio de curvatura de uma superfície

Cúbico de corpo centrado

Cúbico de face centrada

Energia interna do sistema

Espectroscopia por dispersão de energia

Energia livre de Helmholtz

Aceleração da gravidade

Entalpia

Dureza Brinell

Hexagonal compacto

Hexagonal

Joint committee on powder diffraction standards

Constante $\approx 0,3$

Adimensional

Microscópio eletrônico de varredura

Número de mol
$\AA$

m

$\mathrm{J} / \mathrm{mol}$

$\mathrm{J} / \mathrm{mol}$

$\mathrm{m} / \mathrm{s}^{2}$

$\mathrm{J} / \mathrm{mol} . \mathrm{K}$
UNIDADE

$\AA$

$\mathrm{m}^{2}$ 
Ort

S

$\mathrm{t}$

$\mathrm{T}$

TCC

Tetr

UNS

V

VOD

$S_{\mathrm{L} / \mathrm{S}}$

ZAC

$\alpha$

$\delta$

$\gamma_{2}$

$\gamma_{S L}$

$\gamma_{s v}$

$\gamma_{L V}$

$\mu$

$\sigma_{\mathrm{y}}$

$\sigma_{\mathrm{r}}$

$\theta$

$\rho$
Ortorrômbico

Entropia do sistema

Tempo

Temperatura

Tetragonal de corpo centrado

Tetragonal

Unified Numbering System

Volume

$\mathrm{m}^{3}$

Vacuum oxigen decarburization

Coeficiente de espalhamento líquido/sólido

Adimensional
$\mathrm{J} / \mathrm{mol} . \mathrm{K}$

S

$\mathrm{K}$

$$
\text { Zona afetada pelo calor }
$$

Ferrita

Ferrita delta

Austenita secundária

Energia de superfície sólido/líquido

$\mathrm{mN} / \mathrm{m}$

Energia de superfície sólido/vapor $\quad \mathrm{mN} / \mathrm{m}$

Energia de superfície líquido/líquido $\mathrm{mN} / \mathrm{m}$

Potencial químico

$\mathrm{J} / \mathrm{mol}$

Tensão limite de escoamento

$\mathrm{MPa}$

Tensão limite de resistência

$\mathrm{MPa}$

Ângulo de contato da gota líquida

Graus

Densidade

$\mathrm{g} / \mathrm{mm}^{3}$ 


\section{Resumo}

Os aços inoxidáveis duplex (AID) caracterizam-se pela sua microestrutura composta por austenita numa matriz ferrítica, com fração volumétrica média de $50 \%$ para cada fase. A combinação destas características confere-lhes excelente resistência mecânica e à corrosão. A soldagem/junção destes aços é frequentemente uma operação crítica, já que, ao sofrer ciclos térmicos, estes aços têm suas propriedades alteradas. Portanto, processos de junção com ausência de gradientes de temperatura, como a brasagem, mostram-se uma solução prática para a junção destes aços. No entanto, o adequado desenvolvimento do processo de brasagem em AID envolve considerações importantes a respeito da escolha dos parâmetros de processamento e metal de adição em conjunto com os ciclos térmicos de aquecimento e resfriamento. O presente estudo pretende avaliar a brasabilidade dos AID UNS S32101 (baixa liga), UNS S32304 (baixa liga), UNS S32507 (superduplex) e UNS S32707(hiperduplex), mediante a caracterização da junta brasada. Estes aços foram brasados em forno continuo com metal de adição BNi-7 (Ni-Cr-P), na temperatura de $1100^{\circ} \mathrm{C}$, por tempos de $32 \mathrm{~min}$ e $12 \mathrm{~min}$, seguidos de resfriamento em forno, utilizando-se folgas de 0,5, 0,3 e 0,0 mm. A junta brasada foi caracterizada utilizando-se microscopia ótica e microscopia eletrônica de varredura (MEV). A identificação microestrutural foi realizada via Microanálise Química de Energia Dispersiva de Raios-X (EDS) e difração de Raios-X. Foi identificada na junta brasada dos diferentes AID a fase rica em níquel, assim como fases prejudiciais compostas por fosfetos de níquel e cromo. A fase rica em níquel, que usualmente é denominada de $\gamma-\mathrm{Ni}$, apresenta-se preferencialmente em toda a região da junta, sem a presença de fase intermetálica contínua no centro da junta. No caso dos aços inoxidáveis super e hiperduplex esses apresentaram a formação de fase sigma na região da interface da junta, do lado do metal de base, devido aos ciclos térmicos de brasagem utilizados. 


\begin{abstract}
The duplex stainless steels (DSS) are characterized by its microstructure consisting of austenite in a ferritic matrix with mean volumetric fraction of $50 \%$ for each phase. The combination of these features gives them excellent mechanical strength and corrosion resistance. The welding / joining of these steels are often considered as a critical operation, since, subjected to thermal cycles, they have their microstructures changed and, consequently, their properties. Therefore, joining processes without temperature gradients, like brazing, are shown as a practical solution for joining these steels. However, the proper development of brazing process of DSS involves important issues concerning the choice of processing parameters and the brazing filler metal together with heating and cooling brazing thermal cycles. This study aims at evaluating the brazeability of DSS UNS S32101 (lean duplex), UNS S32304 (lean duplex), UNS S32507 (superduplex) and UNS S32707 (hyperduplex) by characterizing the brazed joint. These steels were brazed in a furnace with filler metal BNi-7 (Ni-Cr-P) at $1100^{\circ} \mathrm{C}$ for times of $32 \mathrm{~min}$ and $12 \mathrm{~min}$, followed by cooling in a continuous brazing furnace, with joint gaps of $0.5,0.3$ and $0.0 \mathrm{~mm}$. The brazed joint was characterized using optical microscopy and scanning electron microscopy (SEM). The phase identifications were performed by microanalysis using energy dispersive X-ray spectroscopy (EDS) and X-ray diffraction. Results showed, for non-ideal joint gaps, in all duplex used in this work, the $\mathrm{Ni}$ rich solid solution, as well as deleterious phases composed of nickel and chromium phosphides. The ideal gap presented Ni rich solid solution, usually called $\gamma-\mathrm{Ni}$, was found continuously without a continuous intermetallic region in the joint center. In the case of super duplex and hyperduplex brazing, the brazing thermal cycles produced the formation of sigma phase in the region of the joint interface, in the base metal.
\end{abstract}




\section{INTRODUÇÃO}

O desenvolvimento dos aços inoxidáveis duplex (AID) há algumas décadas aumentou seu uso na indústria devido a sua excelente combinação de resistência mecânica e à corrosão. Estas excelentes propriedades são consequência direta da microestrutura bifásica característica dos AID, sendo as fases presentes ferrita e austenita, com frações volumétricas aproximadamente iguais. Os AID são frequentemente utilizados nas indústrias química e petroquímica, de papel e celulose, siderúrgicas, alimentícias e de geração de energia.

Dependendo da temperatura e ambiente de trabalho, as propriedades dos AID podem-se ver alteradas, mais precisamente, quando o material é exposto a ciclos térmicos que envolvem altas temperaturas. Os AID durante o resfriamento, a fase ferrítica pode gerar a precipitação de diferentes fases intermetálicas prejudiciais, como a fase sigma e o nitreto de cromo, dependendo da temperatura máxima atingida.

Processos de soldagem ou junção são necessários para a fabricação de equipamentos ou peças com este tipo de aço inoxidável. Os processos tradicionais de soldagem por fusão são frequentemente usados na união de AID. No entanto, as altas temperaturas atingidas pelos processos de soldagem por fusão comprometem a resistência mecânica ou à corrosão, principalmente devido à alteração na fração volumétrica das fases presentes no metal base na condição como recebido, ou devido à precipitação de fases intermetálicas, como apresentado anteriormente.

Processos alternativos para a união de AID, como a brasagem em forno estão sendo estudados, devido ao melhor controle dos parâmetros de processamento durante a união do aço. Na brasagem dos AID em fornos contínuos assim como em fornos à vácuo, é possível um melhor controle de aquecimento, resfriamento e tempo de homogeneização. A alteração das frações volumétricas das fases presentes não ocorre durante a brasagem, uma vez que a adição é escolhida para ter uma temperatura de brasagem que não afeta a fração volumétrica das fases presentes 
na chapa. A junção durante este processo é feita sem fusão do material base, fundindo somente o metal de adição. O preenchimento da folga é por efeito capilar do metal de adição fundido, que está diretamente relacionado com a concentração de oxigênio na atmosfera do forno.

Um dos principais metais de adição para a brasagem dos aços inoxidáveis são as ligas a base de níquel. Este tipo de metal de adição proporciona juntas com excelente resistência a altas temperaturas e à corrosão. Além disso, estas adições possuem temperatura de brasagem próxima de $1100^{\circ} \mathrm{C}$, que está na faixa de tratamento termomecânico para obter a microestrutura balanceada dos AID. Além do cromo, os elementos de liga presentes no metal de adição, como o fósforo, têm a finalidade de reduzir a temperatura de fusão da liga. Este elemento também influência na fluidez e na capilaridade da adição, gerando comportamentos diversos no preenchimento da junta. Adicionalmente as características da adição para brasagem, propriedades do metal base e junta brasada, existe uma faixa de abertura de junta onde é atingido o máximo da resistência mecânica, nos diferentes tipos de adições. Essa faixa ideal é determinada pelo bom preenchimento, pela quantidade e natureza de fases intermetálicas e pela incidência de microporosidade, devido à contração na solidificação. Geralmente quando se forma um eutético descontínuo no centro da junta, esta distância é o valor máximo de folga admissível. 


\section{REVISÃO BIBLIOGRÁFICA}

\subsection{Aços inoxidáveis}

\subsubsection{Aspectos gerais}

O surgimento dos aços inoxidáveis foi o resultado da procura de materiais com maior resistência à corrosão e oxidação do que os mostrados pelos diferentes aços convencionais. Portanto, desde sua descoberta, por volta de 1913, os aços inoxidáveis se desenvolveram, passando inicialmente das aplicações médicas e alimentícias, para as aplicações atuais que envolvem quase todas as indústrias.

Os aços inoxidáveis são ligas de ferro e cromo, sendo que o teor mínimo de cromo para obter resistência em ambientes corrosivos é 11\% [1-3], o alto teor de cromo concede aos aços inoxidáveis resistência à oxidação, isso faz com que sejam, também utilizados em aplicações onde se requer resistência ao calor e à fluência. Com relação à teoria clássica, nestes tipos de aços o mecanismo de proteção contra a corrosão provocada pelo meio ambiente se dá pela formação de uma fina camada de óxido rica em cromo na superfície do material, resultado do contato com o oxigênio do ar, esta camada apresenta características como: forte aderência, compacta e continua. Tal camada é denominada passiva, pois após se formar, permanece praticamente inalterada mesmo em contato com o ar.

Como se pode perceber o cromo é o elemento mais importante nos aços inoxidáveis, seguido pelo níquel. No entanto, também conta-se com outros elementos frequentemente presentes nos aços inoxidáveis para elevar a resistência à corrosão ou para obter estruturas metalúrgicas que cumpram com outras especificações ou requisitos específicos da aplicação, tais como: vanádio, tungstênio, molibdênio, titânio entre outros. O níquel e o molibdênio são elementos que melhoram as características da camada passiva. Elementos como o titânio e o vanádio são usados para controlar efeitos deletérios que são provocados pela precipitação de carbonetos de cromo, pois tais elementos como titânio e vanádio 
formam carbonetos mais estáveis [4]. Outros elementos podem estar presentes em pequenas quantidades como consequência da fabricação do aço ou de impurezas presentes nas matérias primas [3-4].

Com relação ao cromo, deve-se mencionar que a presença crescente deste elemento, diminui a capacidade da liga ser temperável, devido ao cromo diminuir a região de estabilidade da austenita, portanto aumenta a região de estabilidade da ferrita (elemento alfagênico). A Figura 2.1 mostra de forma mais clara o efeito do cromo na zona austenítica em um diagrama Fe-C, como pode ser observado pela figura, conforme o teor de cromo aumenta, a faixa de estabilidade da austenita diminui até praticamente desaparecer, próximo aos $20 \%$. Portanto, esse fato leva à conclusão de que, a medida que se adiciona cromo, cresce a composição das ligas Fe-C-Cr que permitiram a obtenção de endurecimento total por têmpera, ficando assim, tais ligas, reduzidas a limites cada vez mais estreitos de temperabilidade [5].

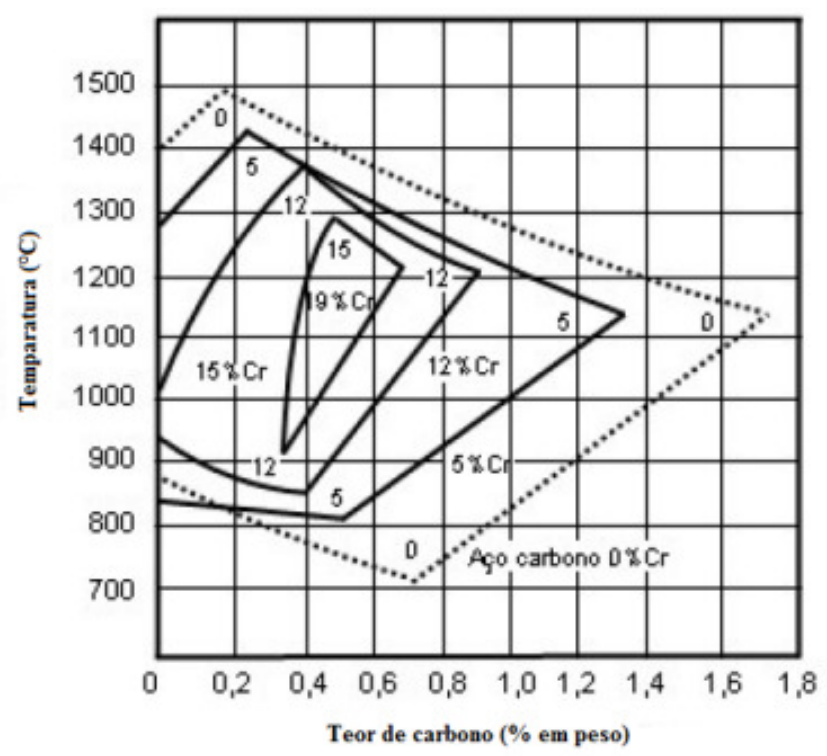

Figura 2.1 - Efeito do teor de cromo sobre o campo austenítico[5]

Em relação ao níquel, como já foi mencionado, este segue o mesmo grau de importância do cromo nos aços inoxidáveis, seu efeito é importante não só pela melhora na resistência à corrosão, mas também no sentido de melhorar suas propriedades mecânicas. De forma contrária ao cromo, o níquel estabiliza a região austenítica (elemento gamagênico), pois à medida que o seu teor é elevado, a região de estabilidade da austenita aumenta a ponto de que com $8 \%$ de níquel, para 
baixos teores de carbono, as ligas apresentam estrutura austenítica mesmo à temperatura ambiente. Aparentemente o níquel exerce uma influência mais decisiva do que o cromo, no que diz respeito às formas alotrópicas do ferro [5].

Considera-se uma forma simples e muito usada para classificar aços inoxidáveis relacionando a composição química e os fatores cristalográficos, os quais estão relacionados com suas propriedades mecânicas e químicas (Erro! Fonte de referência não encontrada.). Os aços inoxidáveis são divididos em cinco famílias com suas próprias características gerais, em termos de propriedades mecânicas e resistência a corrosão. A quarta família obedece mais ao tratamento térmico realizado que as características microestruturais, e elas são[6]:

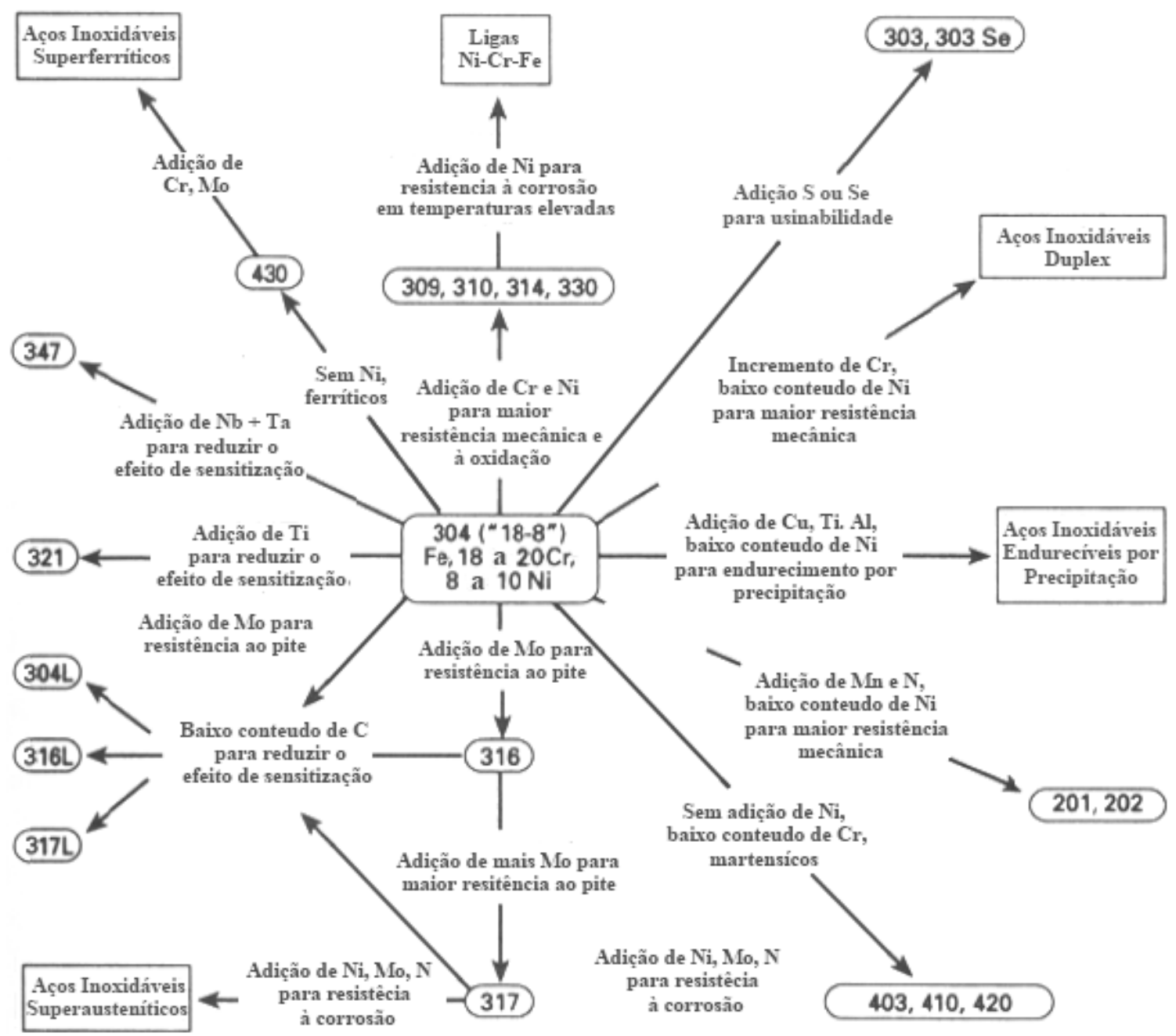

Figura 2.2 - Classificação dos aços inoxidáveis[6]. 
1. Aços inoxidáveis ferríticos, são assim denominados devido a sua estrutura essencialmente ferrítica (CCC), no estado sólido. O teor de cromo nesses tipos de aços está compreendido em uma faixa de 12 a $30 \%$ e possuem um teor de carbono máximo de $0,20 \%$. O cromo que também apresenta estrutura CCC (como a ferrita) amplia a região da fase ferrítica em detrimento da fase austenítica, tendo como consequência uma região pequena de estabilidade da austenita (figura 2.3). Assim os aços ferríticos com teores de cromo acima de $11 \%$ não sofrem transformação de CCC para CFC ao serem resfriados. O baixo teor de carbono nos aços inoxidáveis ferríticos faz com que não sejam endurecíveis por tratamento térmico.

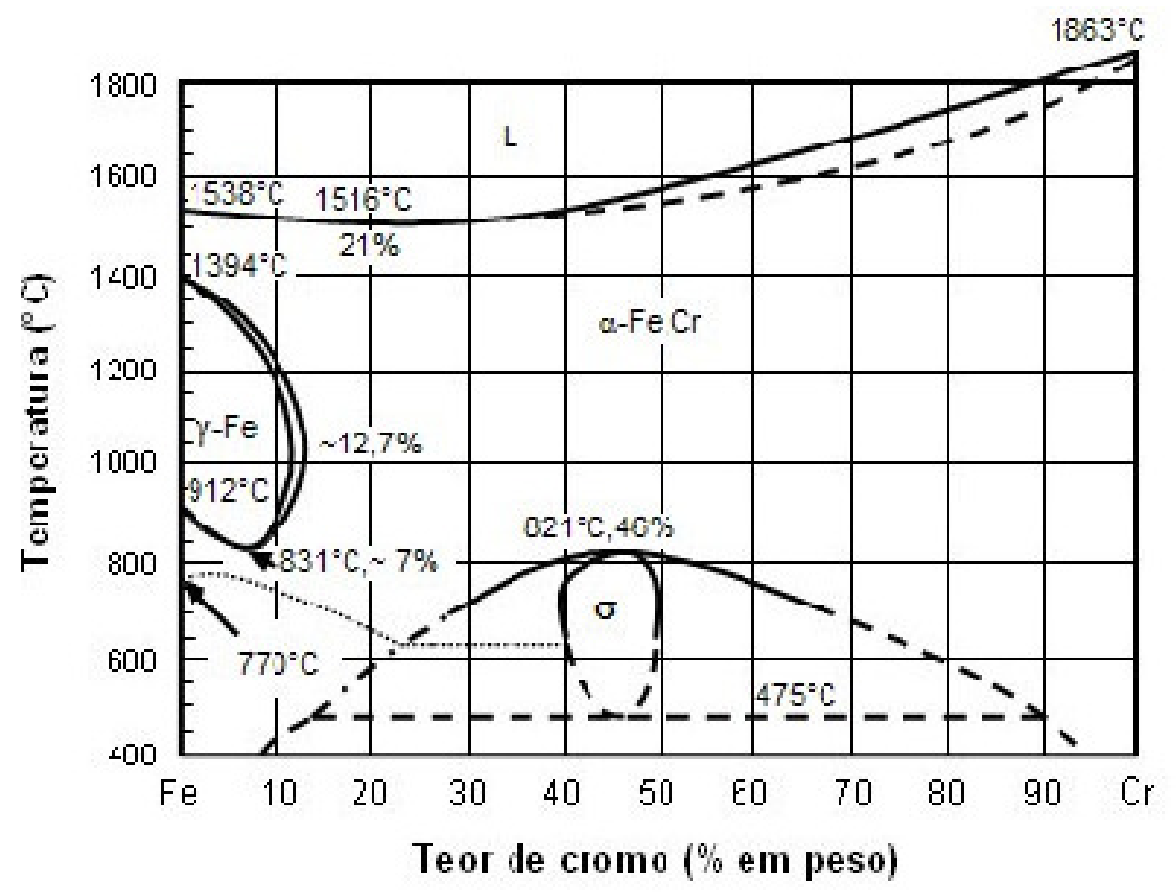

Figura 2.3 - Diagrama de fase Fe-Cr [6].

2. Aços inoxidáveis austeníticos, considerados como os aços inoxidáveis mais resistentes em meios agressivos. A estrutura que possuem é austenítica (CFC), mesmo à temperatura ambiente, o motivo de tal estrutura na temperatura ambiente deve-se à adição do níquel ao ferro. A estrutura CFC do níquel impede que o aço transforme de CFC para CCC durante o resfriamento, permitindo que a estrutura CFC mantenha-se à temperatura ambiente. Esse tipo de aço é considerado uma liga ternária $\mathrm{Fe}-\mathrm{Cr}-\mathrm{Ni}$, com teores de $\mathrm{Cr}$ entre $16 \%$ a $25 \%, 7 \%$ a $20 \%$ de $\mathrm{Ni}$ e baixos teores de carbono. 
Estes aços, como os aços ferríticos, não podem ser endurecidos por tratamento térmico, mas podem ser endurecidos por deformação plástica. Dependendo do teor de níquel, os aços austeníticos respondem ao trabalho a frio com aumento da resistência mecânica, podendo ser utilizados em operações severas de conformação, evitando ruptura prematura e trinca.

Os aços inoxidáveis austeníticos normalmente têm melhor resistência à corrosão que os ferríticos e os martensíticos. No entanto, se essas ligas forem soldadas ou resfriadas lentamente a partir de temperaturas elevadas até 0 intervalo de $870^{\circ} \mathrm{C}$ a $600^{\circ} \mathrm{C}$, elas podem se tornar susceptíveis à corrosão intergranular, devido à precipitação de carbonetos de cromo nos contornos de grão, sensitizando o material. Um dos meios de evitá-la é com a adição de titânio e de nióbio, porque esses elementos fixam o carbono na forma de carbonetos mais estáveis [4-5].

3. Aços inoxidáveis martensíticos, estes aços são constituídos fundamentalmente por uma liga $\mathrm{Fe}-\mathrm{Cr}$, contendo um teor de cromo variando entre 11,5\% e 18\% [5]. Estas ligas são ferro-magnéticas e possuem estrutura tetragonal de corpo centrado (TCC) quando temperadas. Estes aços recebem esta denominação devido ao desenvolvimento de uma estrutura martensítica quando são submetidos a tratamentos de austenitização e têmpera. Após o tratamento térmico de têmpera, a resistência mecânica que o aço pode obter dependerá do teor de carbono, elemento que desempenha um papel importante e permite classificá-los como aços martensíticos de baixo, médio e alto carbono. A adição de um elemento gamagênico como o carbono ou o nitrogênio aumenta o tamanho do campo austenítico, permitindo uma maior adição de cromo. Desse modo, é possível obter uma composição que possibilita a transformação martensítica com alto conteúdo de cromo, que garanta a passividade e ao mesmo tempo uma boa resistência mecânica e dureza. No entanto a resistência à corrosão é relativamente baixa quando comparada aos aços do tipo ferríticos e austeníticos. De tal forma, que a seleção entre um aço ferrítico ou austenítico e um martensítico seja feita em 
função do compromisso entre as propriedades mecânicas e a resistência à corrosão [7].

4. Aços inoxidáveis endurecidos por precipitação, são ligas cromo-níquel, onde o teor de cromo está entre 12 e 18\% e o níquel está entre 3 e 10\%. Caracterizam-se por poderem ter suas propriedades mecânicas melhoradas por tratamento de envelhecimento. Constituem uma alternativa para os aços inoxidáveis austeníticos quando se deseja combinar resistência à corrosão, boas características de trabalhabilidade e elevadas propriedades mecânicas estáticas e dinâmicas [5]. Podem ser austeníticos, semi-austeníticos ou martensíticos, sendo que a classificação é feita de acordo com a sua microestrutura na condição recozida. Para viabilizar a reação de envelhecimento, muitas vezes se utiliza o trabalho a frio e a adição de elementos de liga como alumínio, titânio, nióbio e cobre.

5. Aços inoxidáveis duplex serão mencionados com maior detalhe no item seguinte. 


\subsection{Aços Inoxidáveis Duplex}

A descrição de uma microestrutura duplex foi feita pela primeira vez por Bain e Griffiths em 1927, eles apresentaram diagramas de fase do sistema Fe-Cr-Ni e descreveram ligas com microestrutura austenítica-ferrítica com porcentagens de cromo de $22-30 \%$ e $2-10 \%$ de níquel. Foi essa, talvez, a primeira menção dos aços inoxidáveis duplex [8]. No entanto, a produção comercial dos aços inoxidáveis duplex ficou disponível a partir de 1930, quando em diferentes partes do mundo, mais precisamente na Europa se desenvolveram diversos tipos [8-9].

O primeiro aço inoxidável com microestrutura ferrítica-austenítica continha de 60$70 \%$ de ferrita após recozimento entre $1000-1050{ }^{\circ} \mathrm{C}$ [9]. Esta microestrutura duplex ofereceu melhores propriedades em comparação aos aços austeníticos. A escassez de matérias primas durante a segunda guerra mundial, em especial a de níquel, promoveu o interesse no desenvolvimento dos aços inoxidáveis duplex. Embora o uso destes aços difundiu-se alguns anos depois, por volta de 1950. Contudo, estudos posteriores com relação aos aços duplex foram pouco sucedidos.

Já no final da década de 1960 e começo de 70, obtiveram-se grandes avanços no desenvolvimento do aço inoxidável duplex com a introdução de novas técnicas no processo de fabricação (AOD e VOD), permitindo um controle mais estrito na composição química e presença de elementos residuais como: oxigênio, enxofre, carbono etc., melhorando o balanço das fases ferrita-austenita [9-10]. Além disso, tornou-se possível o controle efetivo dos níveis de nitrogênio, o que permitiu aumentar a resistência à corrosão e a estabilidade da estrutura duplex em altas temperaturas, particularmente devido aos processos de soldagem.

Durante o ano de 1980, aços inoxidáveis duplex altamente ligados foram desenvolvidos com a finalidade de resistir a ambientes altamente agressivos. Chamados de superduplex, o teor dos elementos de liga como cromo, níquel, molibdênio e nitrogênio eram pronunciadamente mais altos do que os outros aços duplex. Outra particularidade deste tipo de aço era a presença de outros elementos de liga como o cobre e tungstênio. Neste mesmo período, foram desenvolvidos os aços inoxidáveis duplex baixa liga (lean duplex stainless steels). Este tipo de aço apresentava teores de cromo e níquel consideravelmente mais baixos, quando 
comparado com os outros tipos de aços inoxidáveis duplex o que significava uma alternativa de produção mais barata [10].

\subsubsection{Aspectos gerais dos aços inoxidáveis duplex}

Os aços inoxidáveis duplex são ligas baseadas no sistema Fe-Cr-Ni-Mo com reduzidos teores de carbono e adições de nitrogênio. Estes aços apresentam uma microestrutura mista composta por uma fase ferrítica (CCC) e outra austenítica (CFC), onde a matriz é a fase ferrítica. Esta estrutura bifásica, característica deste tipo de aço, é determinada, sobretudo, pelos teores de ferro, cromo e níquel. A proporção da fração volumétrica na liga é aproximadamente de $50 \%$ para cada fase, esta característica confere-lhes boa resistência à corrosão sob tensão, alta resistência à corrosão intergranular, excelentes propriedades mecânicas e boa soldabilidade [8, 11]. Estas propriedades são consequência direta do balanço das fases na microestrutura. Assim, se a proporção de austenita aumenta, a resistência à corrosão sob tensão e a resistência mecânica diminuem, e se a proporção de ferrita aumenta a tenacidade à fratura diminui. Devido a essa combinação de propriedades, aços desta classe têm uma ampla aplicação na engenharia.

Para produzir a estrutura bifásica dos aços inoxidáveis é necessário conciliar um equilíbrio entre os elementos estabilizadores da austenita, ou gamagênicos, tais como níquel, carbono, nitrogênio e de elementos estabilizadores da ferrita, ou alfagênicos, cromo, molibdênio e silício. Contudo, as proporções exatas de austenita e ferrita são determinadas pelo tratamento térmico [12].

A faixa de composição dos componentes tem a seguinte distribuição: 18,5 a 27\% de Cr; 4 a 8\% de Ni; 2 a 4\% de Mo; N inferior a 0,3\%; C menor de 0,03\% e também podem conter adição de elementos como cobre, silício e tungstênio em menores proporções. A tabela 2.1 apresenta a composição química típica dos diferentes tipos de AID. 
Tabela 2.1 - Composição química típica de alguns aços inoxidáveis duplex [8, 10].

\begin{tabular}{|c|c|c|c|c|c|c|c|}
\hline $\begin{array}{c}\text { Nome } \\
\text { comercial }\end{array}$ & UNS & Cr & Ni & Mo & N & $\begin{array}{c}\text { Outros } \\
\text { elementos }\end{array}$ & PRE $^{*}$ \\
\hline \multicolumn{7}{|c|}{ Baixa liga } \\
\hline 3RE60 & S31500 & $18,0-19,0$ & $4,25-5,25$ & $2,5-3,0$ & - & $1,4-2,0 \mathrm{Si}$ & 23 \\
\hline SAF 2304 & S32304 & $21,5-24,5$ & $3,0-5,5$ & - & $0,05-0,20$ & $0,05-0,6 \mathrm{Cu}$ & 25 \\
\hline UR50 & S32404 & $20,5-22,5$ & $5,5-8,5$ & $2,0-3,0$ & 0,20 & $1,0-2,0 \mathrm{Cu}$ & 31 \\
\hline \multicolumn{7}{|c|}{ Liga padrão 22\%Cr } \\
\hline 2205 & S31803 & $21,0-23,0$ & $4,5-6,5$ & $2,5-3,5$ & $0,08-0,20$ & - & 34 \\
\hline \multicolumn{7}{|c|}{ Alta liga } \\
\hline S32205 & $22,0-23,0$ & $4,5-6,5$ & $3,0-3,5$ & $0,14-0,20$ & - & 35 \\
\hline 44LN & S31200 & $24,0-26,0$ & $5,5-6,5$ & $1,2-2,0$ & $0,14-0,20$ & - & 38 \\
\hline DP3 & S32160 & $24,0-26,0$ & $5,5-75$ & $2,5-3,5$ & $0,10-0,30$ & $\begin{array}{c}0,2-0,8 \mathrm{Cu} ; \\
0,1-0,5 \mathrm{~W}\end{array}$ & 38 \\
\hline Ferralium & S32550 & $24,0-27,0$ & $4,5-6,5$ & $2,9-3,9$ & $0,10-0,25$ & $1,5-2,5 \mathrm{Cu}$ & 38 \\
\hline 329 & S32900 & $23,0-28,0$ & $2,5-5,0$ & $1,0-2,0$ & - & - & 33 \\
\hline 7-Mo plus & S32950 & $26,0-29,0$ & $3,5-5,2$ & $1,0-2,5$ & $0,15-0,35$ & - & 36 \\
\hline \multicolumn{7}{|c|}{ Superduplex } \\
\hline UR 52N+ & S32520 & $24,0-26,0$ & $5,5-8,0$ & $3,0-5,0$ & $0,20-0,35$ & $0,5-3,0 \mathrm{Cu}$ & 41 \\
\hline 2507 & S32750 & $24,0-26,0$ & $6,0-8,0$ & $3,0-5,0$ & $0,24-0,32$ & $0,5 \mathrm{Cu}$ & 41 \\
\hline Zeron 100 & S32760 & $24,0-26,0$ & $6,0-8,0$ & $3,0-4,0$ & $0,2-0,3$ & $\begin{array}{c}0,5-1,0 \mathrm{Cu} ; \\
0,5-1,0 \mathrm{~W}\end{array}$ & $>40$ \\
\hline & S39226 & $24,0-26,0$ & $5,5-7,5$ & $2,5-3,5$ & $0,1-0,3$ & $\begin{array}{c}0,2-0,8 \mathrm{Cu} ; \\
0,1-0,5 \mathrm{~W}\end{array}$ & $>40$ \\
\hline DP3W & S39274 & $24,0-26,0$ & $6,0-8,0$ & $2,5-3,5$ & $0,24-0,32$ & $\begin{array}{c}0,2-0,8 \mathrm{Cu} ; \\
1,5-2,5 \mathrm{~W}\end{array}$ & 42 \\
\hline AF918 & S39277 & $24,0-26,0$ & $6,5-8,0$ & $3,0-4,0$ & $0,23-0,33$ & $\begin{array}{c}1,2-2,0 \mathrm{Cu} ; \\
0,8-1,2 \mathrm{~W}\end{array}$ & 42 \\
\hline
\end{tabular}

${ }^{*} \mathrm{PRE}=$ Equivalente de Resistência ao Pite

\subsubsection{Tipos de aços inoxidáveis duplex}

Os diferentes tipos de aços inoxidáveis duplex são, usualmente, separados em três grupos, com relação à composição química:

a. Aços inoxidáveis duplex de baixa liga: Considerados os mais econômicos da família dos aços inoxidáveis duplex devido ao menor teor de elementos de liga, apresentam quantidades típicas de $20-24 \%$ de cromo, $1-5 \%$ de níquel, 0,1-0,3\% de molibdênio e $0,10-0,22 \%$ de nitrogênio. Desenvolvidos para competir comercialmente com os aços inoxidáveis austeníticos do tipo AISI 304L e AISI 316L, em razão de exibir maior resistência mecânica, similar resistência à corrosão por pite e maior resistência à corrosão sob tensão em meios contendo cloretos[10]. Este tipo de aço, ao contrário dos outros tipos de AID são ligados 
com baixos teores de molibdênio, significando uma produção mais econômica. Os aços inoxidáveis duplex de baixa liga podem ser restritos àqueles sem teor de molibdênio e teor de níquel inferior a 3\%, sendo um dos mais representativos o tipo UNS S32304. Por outro lado, têm-se aqueles que exibem o teor de níquel pronunciadamente mais baixo como consequência do aumento no teor de nitrogênio e manganês, como o recentemente desenvolvido UNS S32101[13].

b. Aços inoxidáveis duplex estandar: nessa família, enquadram-se os duplex mais utilizados no mercado. Sendo o tipo UNS S31803 o dominante e de maior comercialização. Esta série apresenta resistência à corrosão intermediária entre os inoxidáveis austeníticos comuns e aços inoxidáveis superausteníticos com 5 e $6 \%$ de molibdênio.

c. Aços inoxidáveis duplex de alta liga: comumente designados por aços inoxidáveis superduplex, estes aços apresentam teores de elementos de liga típicos de 24-29\% de cromo, 4,5-8\% de níquel, 2,7-4,5\% de molibdênio, 0,100,35\% de nitrogênio, algumas das classes podem ou não ter adição de cobre e tungstênio. Os aços inoxidáveis superduplex são especialmente projetados para aplicações que requerem alta resistência mecânica e alta resistência à corrosão em ambientes extremamente agressivos. A elevada resistência à corrosão desta família compete com os aços inoxidáveis superausteníticos que possuem entre 5 a $6 \%$ de molibdênio e ligas a base de níquel. A série UNS $\$ 32750$ é considerada a mais representativa desta família. Por outro lado, uma subfamília deste grupo com consideráveis incrementos nos teores de cromo (27-32\%), molibdênio (até $5 \%$, níquel (6-8\%) e nitrogênio $(0,4-0,5 \%)$, estabelece uma nova geração de AID de alta liga [14]. Chamados de Hyperduplex estes aços possuem alta resistência à corrosão e excelentes propriedades mecânicas em ambientes sumamente agressivos a elevadas temperaturas, características que destaca este aço do superduplex. O hyperduplex de maior comercialização é a série UNS S32707. 
O desenvolvimento metalúrgico nas diferentes famílias de AID pode ser descrito mediante a análise química na sua relação cromo - molibdênio e Nitrogênio, assim como apresentado na figura 2.4.

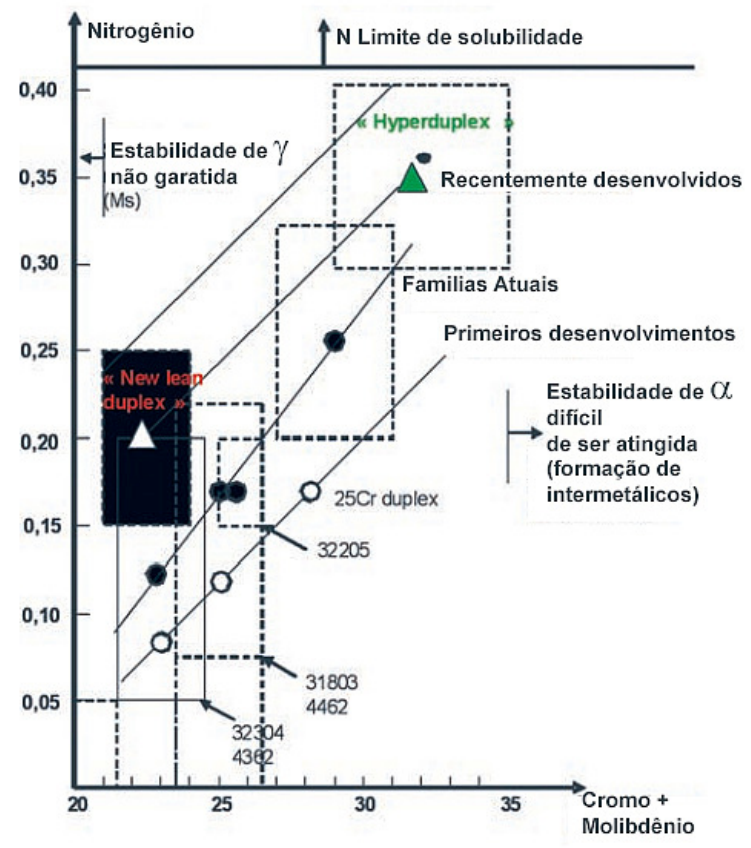

Figura 2.4 - Análise químico no desenvolvimento dos AID[14].

\subsubsection{Produção}

Uma completa microestrutura ferrítica é formada durante a solidificação. Por outro lado a transformação parcial para austenita acontece durante o resfriamento, à medida que a temperatura diminui a matriz ferrítica transforma-se em grãos austeníticos que nucleiam e crescem, primeiramente, nos contornos de grão ferríticos, e depois ao longo de direções cristalográficas preferenciais dentro da ferrita. Os aços inoxidáveis duplex são processados por laminação a frio seguido por um recozimento de recristalização conveniente e têmpera, para obter proporções iguais das duas fases. Durante a laminação a quente e depois com um tratamento de recozimento, a microestrutura conserva-se dentro do campo bifásico do diagrama de fases $\mathrm{Fe}-\mathrm{Ni}-\mathrm{Cr}$, constituindo-se de lamelas alternadas de ferrita e austenita. 


\subsubsection{Propriedades mecânicas dos aços inoxidáveis duplex}

As excelentes propriedades mecânicas que apresentam os aços inoxidáveis duplex estão estreitamente relacionadas com as características de cada fase [11], sendo responsável pelos elevados valores de alongamento a fase austenítica e à fase ferrítica pelo elevado limite de escoamento [11, 15]. Comparados com os aços inoxidáveis austeníticos, o valor do limite de escoamento chega à ordem de duas vezes e é notoriamente superior do que os aços ferríticos [8, 16-17]. Além disso, apresentam um alongamento mínimo em torno de $25 \%$. A resistência ao impacto exibida por estes aços encontra-se em um valor intermediário entre os aços austeníticos e ferríticos [8]. No entanto, a tenacidade está limitada à fração volumétrica e distribuição da ferrita. Com uma fração volumétrica de austenita da ordem de $40 \%$, obtém-se prevenção efetiva ao crescimento de trincas. Desta forma, a orientação e a morfologia da estrutura dos aços duplex são importantes na avaliação da tenacidade.

A tabela 2.2 mostra as principais propriedades mecânicas de várias classes de aços inoxidáveis duplex segundo a norma ASTM A790.

Tabela 2.2 - Propriedades mecânicas dos diferentes aços inoxidáveis duplex segundo a norma ASTM A790[18]

\begin{tabular}{|c|c|c|c|c|}
\hline $\begin{array}{c}\text { Classificação } \\
\text { UNS }\end{array}$ & $\begin{array}{c}\text { Limite de } \\
\text { escoamento }\left(\sigma_{\mathrm{y}}\right) \\
{[\mathrm{MPa}]}\end{array}$ & $\begin{array}{c}\text { Limite de resistência } \\
\text { à tração }\left(\sigma_{\mathrm{r}}\right) \\
{[\mathrm{MPa}]}\end{array}$ & $\begin{array}{c}\text { Alongamento } \\
{[\%]}\end{array}$ & $\begin{array}{c}\text { Dureza } \\
{[\mathrm{HB}]}\end{array}$ \\
\hline S31200 & 450 & 690 & 25 & 280 \\
\hline S31500 & 440 & 630 & 30 & 290 \\
\hline S31803 & 450 & 620 & 25 & 290 \\
\hline S32304 & 400 & 600 & 25 & 290 \\
\hline S32550 & 550 & 760 & 15 & 297 \\
\hline S32750 & 550 & 800 & 15 & 310 \\
\hline S32760 & 550 & 750 & 25 & $200-270$ \\
\hline S32900 & 485 & 620 & 20 & 271 \\
\hline S32950 & 480 & 690 & 20 & 290 \\
\hline
\end{tabular}

O comportamento mecânico dos aços inoxidáveis duplex está fortemente relacionado com a característica de cada fase, por isso o balanceamento entre as 
frações volumétricas de austenita e ferrita deve estar próximo a 50\% para cada uma das fases, a fim de se maximizar as propriedades mecânicas.

\subsubsection{Propriedades físicas dos aços inoxidáveis duplex}

Os aços inoxidáveis duplex exibem baixos coeficientes de expansão térmica, similar aos aços carbono. Além disso, a condutividade térmica é maior do que a dos aços inoxidáveis austeníticos, propriedade física que combinada com a alta resistência mecânica permite reduzir a espessura das paredes de componentes de diversos equipamentos, como por exemplo, trocadores de calor. Por apresentarem $50 \%$ de ferrita na sua estrutura têm um comportamento fortemente magnético, permitindo o uso de fixadores magnéticos durante o processo de usinagem.

A tabela 2.3 apresenta as principais características físicas dos aços inoxidáveis duplex, estabelecendo um comparativo com os dos aços inoxidáveis austeníticos e ferríticos. Observando a tabela 2.3, nota-se que os aços inoxidáveis duplex apresentam comportamento intermediário entre os aços inoxidáveis austeníticos e ferríticos.

Tabela 2.3 - Propriedades físicas dos aços inoxidáveis duplex e outros aços[10].

\begin{tabular}{|c|c|c|c|c|c|c|}
\hline Material & UNS & Temperatura & $\begin{array}{l}\text { Módulo } \\
\text { de } \\
\text { Young } \\
\text { (GPa) }\end{array}$ & $\begin{array}{l}\text { Coeficiente } \\
\text { de } \\
\text { Expansão } \\
\text { Térmica } \\
\left(10^{-6} /{ }^{\circ} \mathrm{K}\right)\end{array}$ & $\begin{array}{c}\text { Calor } \\
\text { Específico } \\
\left(\mathrm{J} / \mathrm{kg}^{\circ} \mathrm{K}\right)\end{array}$ & $\begin{array}{l}\text { Condutibilidade } \\
\text { Térmica } \\
\left(\mathrm{W} / \mathrm{m}^{\circ} \mathrm{K}\right)\end{array}$ \\
\hline \multirow{2}{*}{ Ferrítico } & $\mathrm{S} 43000$ & 20 & 205 & 10 & 480 & 22 \\
\hline & S44700 & 20 & 205 & 10 & 480 & 21 \\
\hline \multirow{2}{*}{ Austenítico } & S30400 & 20 & 205 & 16 & 520 & 16 \\
\hline & N08904 & 20 & 205 & 16 & 544 & 15 \\
\hline \multirow{5}{*}{ Duplex } & \multirow[t]{4}{*}{ S31803 } & 20 & 200 & - & 470 & 14 \\
\hline & & 100 & 190 & 13 & 500 & 15 \\
\hline & & 200 & 180 & 14 & 530 & 17 \\
\hline & & 300 & 170 & 14,5 & 560 & 18 \\
\hline & S32304 & 20 & 200 & 13 & 470 & 16 \\
\hline \multirow{5}{*}{ Superduplex } & S32750 & 20 & 200 & 13 & 470 & 14 \\
\hline & S32760 & 20 & 190 & 12,8 & 482 & 12,9 \\
\hline & \multirow[t]{3}{*}{ S32520 } & 20 & 205 & 13,5 & 450 & 17 \\
\hline & & 100 & 195 & 14 & 500 & 18 \\
\hline & & 200 & 185 & 14,5 & 530 & 19 \\
\hline
\end{tabular}




\subsubsection{Resistência à corrosão dos aços inoxidáveis duplex}

A resistência à corrosão dos aços inoxidáveis duplex, assim como dos diversos aços inoxidáveis depende, principalmente, dos elementos de liga presentes na composição química do aço, embora outros fatores como tamanho de grão, distribuição e morfologia de inclusões, precipitação de fases e qualidade da superfície também exerçam influência.

Elementos de liga como o cromo, molibdênio e nitrogênio são importantes na resistência à corrosão dos aços inoxidáveis duplex [17]. O níquel serve principalmente para estabilizar a fase austenítica. No entanto a distribuição destes elementos não é uniforme nas duas fases, tanto o cromo como o molibdênio permanecem na fase ferrítica, enquanto o níquel e o nitrogênio na fase austenítica. A distribuição não uniforme dos elementos nas fases afeta a homogeneidade da resistência à corrosão determinando o comportamento do material. Nos primeiros aços inoxidáveis duplex, a fase austenítica era preferencialmente atacada, já nos modernos aços inoxidáveis duplex com altos teores de nitrogênio, foi possível conseguir um apurado balanceamento de elementos de liga, equilibrando a resistência à corrosão nas duas fases [10].

O comportamento dos aços inoxidáveis duplex frente às diversas formas de corrosão é considerado similar e até superior comparado com os dos aços inoxidáveis austeníticos. A excelente resistência dos aços inoxidáveis duplex frente à corrosão tornou-os uma boa opção para competir com os aços inoxidáveis austeníticos, pois além de apresentar ótimas propriedades mecânicas são mais econômicos devido ao menor teor de elementos de liga.

A resistência à corrosão localizada nos aços inoxidáveis duplex, a qual é maior do que os aços austeníticos, é função da resistência à corrosão localizada da fase austenita e ferrita. Nestes aços a corrosão localizada ataca frequentemente os contornos de grão ferrita/austenita, devido os contornos de grão serem lugares preferenciais de segregação de impurezas [8]. 


\subsubsection{Soldabilidade dos aços inoxidáveis duplex}

A melhora na soldabilidade dos aços inoxidáveis duplex tem sido uma das principais razões para que sua utilização se expandisse de forma tão destacável. O desenvolvimento metalúrgico do aço levou a uma maior estabilidade microestrutural durante os ciclos térmicos associados aos processos de soldagem, resultando em menores riscos para a precipitação de fases intermetálicas. Os elevados teores de carbono $(0,1-0,2 \%)$ nos primeiros aços inoxidáveis duplex promoviam a perda de resistência à corrosão intergranular provocada pela precipitação de carbonetos [4]. Problema que foi resolvido com o desenvolvimento de aços inoxidáveis duplex com baixos teores de carbono e a adição de nitrogênio [4, 10, 19]. Este fato foi muito importante no caso dos aços inoxidáveis duplex altamente ligados e nos superduplex.

A soldabilidade é boa e muito parecida a dos aços austeníticos. Porém, deve-se tomar cuidados especiais com alguns tipos de fragilizações que podem ocorrer. Estas precipitações estão diretamente relacionadas ao histórico térmico do material soldado, ou a energia de soldagem utilizada.

Os aços inoxidáveis duplex podem ser soldados pela maioria dos processos de soldagem, tais como: TIG, MIG, plasma, eletrodo revestido, arco submerso, resistência elétrica, feixe de elétrons entre outros [20-21]. No entanto o uso de processos com uma fonte de energia elevada tem suas complicações, pois as altas temperaturas atingidas e as elevadas velocidades de resfriamento, comprometendo a formação de austenita e consequentemente o balanço das fases [22].

Para manter uma alta resistência à corrosão e ductilidade a soldadura deve conter uma fração volumétrica de 30 a $70 \%$ de ferrita [23]. Isto implica a necessidade de ter metais de adição que tenham similar composição com o metal de base e assim garantir uma microestrutura balanceada na zona fundida do cordão, utiliza-se consumíveis com basicamente a mesma composição química excetuando o níquel. Pode-se adicionar com o mesmo fim, nitrogênio no gás de proteção tanto no caso de soldagem com metal de adição ou sem ele. 


\subsubsection{Solidificação}

Os aços inoxidáveis com baixo conteúdo de carbono podem solidificar por diversos mecanismos ou modos: ferrítico, ferrítico-austenítico, austenítico-ferrítico e austenítico. Os aços inoxidáveis duplex com baixo teor de carbono solidificam em uma estrutura ferrítica e a austenita forma-se no estado sólido. A temperatura "liquidus" está aproximadamente entre 1445 e $1450^{\circ} \mathrm{C}$ e a temperatura "solidus" está entre 1385 e $1390^{\circ} \mathrm{C}$. No caso de aços inoxidáveis duplex com alto teor de carbono, também é a estrutura ferrítica que solidifica primeiro, o líquido residual enriquecido em elementos estabilizadores da austenita fazem que a estrutura seja formada junto com uma pequena quantidade de carbonetos [24].

\subsubsection{Precipitação de fases nos aços inoxidáveis duplex}

Os AID quando submetidos a tratamentos térmicos, processos de soldagem ou condições de serviço na qual a faixa de temperatura está entre 300-1000 ${ }^{\circ} \mathrm{C}$, tendem a formar diversas fases secundárias que afetam sua resistência mecânica e à corrosão [8, 25]. Das fases secundárias que mais se destacam estão: a fase sigma $(\sigma)$, nitretos de cromo $\left(\mathrm{Cr}_{2} \mathrm{~N}\right)$, austenita secundária $\left(\gamma_{2}\right)$, fase "chi" $(\chi)$, fase $\mathrm{R}$, nitretos $\pi$, carbonetos do tipo $\mathrm{M}_{7} \mathrm{C}_{3}$ e $\mathrm{M}_{23} \mathrm{C}_{6}$ e precipitados ricos em cobre $(\varepsilon)$. A temperatura de precipitação de fases secundárias é separada em duas regiões: uma abaixo dos $600^{\circ} \mathrm{C}$ e a outra entre $600-1000^{\circ} \mathrm{C}$, como é apresentado na figura 2.5 .

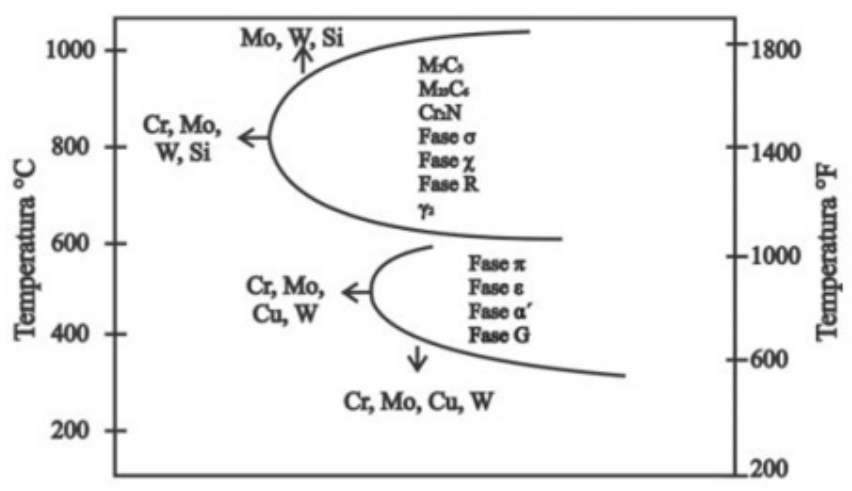

Figura 2.5 - Precipitação de fases secundárias nos aços inoxidáveis duplex [26]. 
A ferrita por apresentar maior quantidade de elementos de liga e um alto coeficiente de difusividade é mais susceptível a formar precipitados do que a austenita. Dos elementos que marcam tal susceptibilidade estão o cromo e o molibdênio.

A tendência de precipitação das fases secundárias vê-se fortemente afetada pelo conteúdo de elementos de liga e, portanto, difere marcadamente para cada classe de aço inoxidável duplex. Sendo por consequência, os aços inoxidáveis superduplex pronunciadamente mais propensos a formar precipitados [25].

A Tabela 2.4 relaciona as principais fases secundárias que podem precipitar nos aços inoxidáveis duplex.

Tabela 2.4 - Principais fases que podem precipitar nos aços inoxidáveis duplex[24].

\begin{tabular}{|c|c|c|c|c|c|}
\hline Fases & $\begin{array}{l}\text { Estrutura } \\
\text { cristalina }\end{array}$ & $\begin{array}{l}\text { Átomos } \\
\text { por celula }\end{array}$ & $\begin{array}{l}\text { Grupo } \\
\text { espacial }\end{array}$ & $\begin{array}{l}\text { Parâmetro de rede } \\
(\mathrm{nm})\end{array}$ & Composição \\
\hline \multicolumn{6}{|c|}{ Fases principais } \\
\hline $\begin{array}{c}\text { Austenita } \\
(\gamma)\end{array}$ & $\mathrm{cfc}$ & 4 & Fm3m & $a=0,358-0,362$ & $(\mathrm{Fe}, \mathrm{Cr}, \mathrm{Ni}, \mathrm{Mo}, \mathrm{N})$ \\
\hline $\begin{array}{l}\text { Ferrita } \\
(\delta \text { ou } \alpha)\end{array}$ & $\operatorname{ccc}$ & 2 & $\operatorname{Im} 3 \mathrm{~m}$ & $a=0,285-0,289$ & (Fe,Cr,Ni,Mo) \\
\hline \multicolumn{6}{|c|}{ Fases intermetálicas } \\
\hline $\begin{array}{l}\text { Sigma } \\
(\sigma)\end{array}$ & tetragonal & 30 & $\mathrm{P} 4_{2} / \mathrm{mnm}$ & $\begin{array}{c}a=0,87-0,92 \\
c=0,45544-0,48\end{array}$ & $(\mathrm{Fe}, \mathrm{Ni})_{\times}(\mathrm{Cr}, \mathrm{Mo})$ \\
\hline $\begin{array}{l}\text { Chi } \\
(\chi)\end{array}$ & $\operatorname{ccc}$ & 58 & $143 m$ & $a=0,881-0,895$ & $\begin{array}{c}\mathrm{Fe}_{36} \mathrm{Cr}_{12} \mathrm{Mo}_{10} \\
(\mathrm{Fe}, \mathrm{Ni})_{36} \mathrm{Cr}_{18} \mathrm{Mo}_{4}\end{array}$ \\
\hline $\begin{array}{l}\text { Laves } \\
(\eta)\end{array}$ & hcp & 12 & $\mathrm{P}_{3} / \mathrm{mmc}$ & $\begin{array}{c}a=0,473-0,483 \\
c=0,772-0,786\end{array}$ & $\begin{array}{c}\mathrm{Fe}_{2} \mathrm{Mo} ; \mathrm{Fe}_{2} \mathrm{Nb} \\
\mathrm{Fe}_{2} \mathrm{Ta} ; \mathrm{Fe}_{2} \mathrm{Ti} ; \mathrm{Fe}_{2} \mathrm{~W}\end{array}$ \\
\hline G & $\operatorname{ccc}$ & 116 & Fd3m & $a=1,115-1,120$ & $\begin{array}{l}\mathrm{Ni}_{16} \mathrm{Nb}_{6} \mathrm{Si}_{7} ; \mathrm{Ni}_{16} \mathrm{Ti}_{6} \mathrm{Si}_{7} \\
(\mathrm{Ni}, \mathrm{Fe}, \mathrm{Cr})_{16}\left(\mathrm{Nb}, \mathrm{Ti}_{6}\right)_{6} \mathrm{Si}_{7}\end{array}$ \\
\hline $\mathrm{R}$ & hcp & $53(159)$ & R3 & $\begin{array}{l}a=1,08-1,10 \\
c=1,92-1,94\end{array}$ & $\begin{array}{c}\mathrm{Fe}_{22} \mathrm{Mo}_{18} \mathrm{r}_{13} \\
(\mathrm{Fe}, \mathrm{Ni})_{10} \mathrm{Cr}_{5} \mathrm{Mo}_{3} \mathrm{Si}_{2}\end{array}$ \\
\hline \multicolumn{6}{|c|}{ Carbonetos } \\
\hline $\mathrm{M}_{23} \mathrm{C}_{6}$ & $\mathrm{cfc}$ & 116 & $\mathrm{Fm} 3 \mathrm{~m}$ & $a=0,1,057-1,068$ & $\begin{array}{c}(\mathrm{Cr}, \mathrm{Fe}, \mathrm{Mo})_{23} \mathrm{C}_{6} \\
\left(\mathrm{Cr}_{16} \mathrm{Fe}_{5} \mathrm{Mo}_{2}\right)_{23} \mathrm{C}_{6}\end{array}$ \\
\hline $\mathrm{M}_{7} \mathrm{C}_{3}$ & Ortorrom. & 40 & Pnma & $\begin{array}{l}a=1,395-1,400 \\
c=0,452-0,453\end{array}$ & $(\mathrm{Cr}, \mathrm{Fe},)_{7} \mathrm{C}_{3}$ \\
\hline \multicolumn{6}{|c|}{ Nitretos } \\
\hline $\mathrm{M}_{2} \mathrm{~N}$ & trigonal & 9 & P31m & $\begin{array}{l}a=0,475-0,480 \\
c=0,443-0,447\end{array}$ & $(\mathrm{Cr}, \mathrm{Fe},)_{2} \mathrm{~N}$ \\
\hline MN & $\mathrm{cfc}$ & 8 & Fm3m & $a=0,4097-0,4577$ & $\mathrm{CrN} ; \mathrm{ZrN} ; \mathrm{TiN} ; \mathrm{Nb} ; \mathrm{VN}$ \\
\hline
\end{tabular}

$>$ Fase sigma $(\sigma)$ : geralmente é considerada a mais importante das fases que podem se formar nos aços inoxidáveis duplex por causa da sua ação prejudicial sobre a tenacidade e resistência à corrosão. A fase $\sigma$ é um composto intermetálico de natureza muito dura e frágil enriquecido em cromo, molibdênio e silício. A faixa de temperatura de precipitação desta fase varia 
entre 600 e $1000^{\circ} \mathrm{C}$ e frequentemente os sítios preferenciais de precipitação são as junções triplas e contornos de grão ferrita/ austenita [8], crescendo para o interior da ferrita.

A formação da fase $\sigma$ é fortemente influenciada pela composição química da liga, principalmente pelo cromo e molibdênio. Tendo em vista que nos AID a ferrita é a fase com maior conteúdo destes elementos, além de apresentar metaestabilidade na faixa de temperatura de precipitação da fase $\sigma$, pode-se deduzir que a precipitação da fase $\sigma$ dá-se principalmente pela decomposição da ferrita. Mais especificamente pela decomposição eutetóide da ferrita em fase $\sigma$ e austenita secundária $\left(\alpha \rightarrow \sigma+\gamma_{2}\right.$ ) como apresentado na figura 2.6.
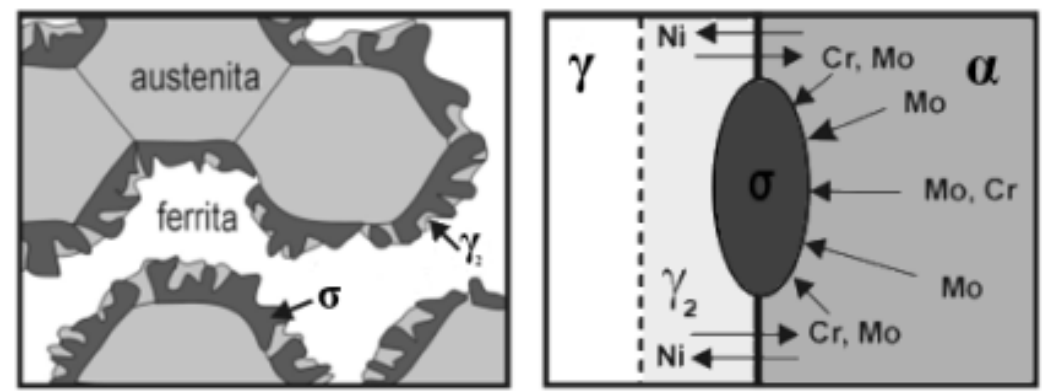

Figura 2.6 - Diagrama de formação de fase sigma nos aços inoxidáveis duplex seguindo uma decomposição eutetóide[27].

Elementos como o tungstênio, que frequentemente são adicionados nos aços inoxidáveis duplex, exercem influência na formação da fase $\sigma$. Sendo reportado [28], como acelerador da cinética de precipitação desta fase. No entanto, também foi relatado que a substituição de molibdênio por tungstênio na liga diminui notavelmente a quantidade de fase $\sigma$ formada [29].

A temperatura de tratamento de solubilização também influencia a precipitação da fase $\sigma$. Precipitando mais rapidamente para temperaturas menores, enquanto à temperaturas maiores a cinética de precipitação é mais lenta, obtendo-se baixas frações volumétricas de sigma [30]. Este fato devese a elementos como o cromo e molibdênio serem mais bem acomodados em solução sólida substitucional em temperaturas maiores, dificultando dessa forma a precipitação de fase $\sigma$ durante o resfriamento rápido.

A presença da fase $\sigma$ na microestrutura dos aços inoxidáveis duplex compromete tanto as propriedades mecânicas como a resistência à corrosão, 
como mencionado anteriormente. É reportado na literatura que a presença de $1 \%$ de fase $\sigma$ leva a uma redução aproximada de $50 \%$ na energia absorvida durante o ensaio de impacto [31]. Em relação a resistência à corrosão, a presença de fase $\sigma$ pode aumentar a velocidade de corrosão em até oito vezes. Diminuindo principalmente a resistência à corrosão localizada.

> Fase Chi $(\chi)$ : proporcional a fase $\sigma$, esta fase é frágil e indesejável nos AID, pois tem um efeito deletério tanto na resistência à corrosão como na tenacidade. A influência desta fase está diretamente ligada à fase sigma, já que na maior parte das vezes essas duas fases coexistem [8]. A temperatura de precipitação da fase $\chi$ nos aços inoxidáveis duplex está na faixa de $700^{\circ} \mathrm{C}$ a $900^{\circ} \mathrm{C}$, usualmente encontra-se em menores quantidades que a fase $\sigma, 0$ que faz comparativamente menos importante, no entanto, seu efeito não pode ser desprezado. A fase $\chi$ é mais instável do que a fase $\sigma$ e pode eventualmente transformar-se em fase $\sigma$ após longos tempos de exposição. Por ser um precipitado rico em molibdênio, sua formação consome grandes quantidades deste elemento, gerando um "empobrecimento" nas zonas adjacentes ao precipitado, portanto, é de se esperar que a resistência à corrosão seja consideravelmente reduzida.

$>$ Carbonetos $\left(\mathbf{M}_{23} \mathbf{C}_{6}\right.$ e $\left.\mathbf{M}_{7} \mathbf{C}_{3}\right)$ : A precipitação desta fase pode apresentar as formas $\mathrm{M}_{7} \mathrm{C}_{3}$ e $\mathrm{M}_{23} \mathrm{C}_{6}$, sendo o segundo mais comum. $A$ temperatura de precipitação está compreendida entre $950^{\circ} \mathrm{C}$ e $1050^{\circ} \mathrm{C}$ para o tipo $\mathrm{M}_{7} \mathrm{C}_{3} \mathrm{e}$ abaixo de $950^{\circ} \mathrm{C}$ para o tipo $\mathrm{M}_{23} \mathrm{C}_{6}$. Ambos os tipos de carbonetos precipitam, predominantemente nas interfaces ferrita/austenita, mas também podem precipitar nos contornos de grão ferrita/ferrita e austenita/austenita [8]. A formação do carboneto $\mathrm{M}_{23} \mathrm{C}_{6}$ segue a reação eutetóide do tipo $\delta \rightarrow \mathrm{M}_{23} \mathrm{C}_{6}+$ $\gamma_{2}$, causando o deslocamento da interface para o lado da ferrita. O crescimento dos carbonetos se dá para o interior da ferrita [32], conforme representado na figura2.7. 


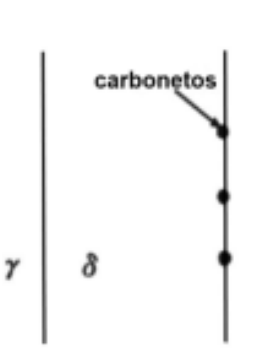

(a) (b)

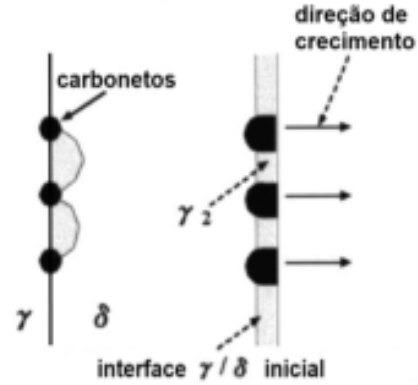

(c)

(d)

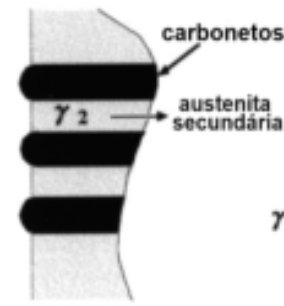

(e)

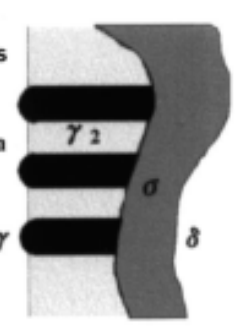

(f)

Figura 2.7 - Representação esquemática da precipitação e evolução microestrutural dos carbonetos nos aços inoxidáveis duplex [32].

Nos aços inoxidáveis duplex e super duplex atuais, a precipitação de carbonetos não têm mais um papel importante, devido ao baixo teor de carbono que apresentam estes aços, normalmente na faixa de 0,01 a 0,02\%.

> Nitretos de cromo $\left(\mathrm{Cr}_{2} \mathrm{~N}\right)$ : A precipitação de $\mathrm{Cr}_{2} \mathrm{~N}$ tornou-se um assunto importante devido ao aumento do teor de nitrogênio como elemento de liga nos atuais aços inoxidáveis duplex. A formação de $\mathrm{Cr}_{2} \mathrm{~N}$ ocorre no intervalo de temperatura entre 700 e $900^{\circ} \mathrm{C}$, causado principalmente devido à supersaturação de nitrogênio na ferrita durante o resfriamento rápido desde temperaturas altas de solubilização [33]. A precipitação dá-se preferencialmente nos contorno de grão ferrita/ferrita, podendo também precipitar intergranularmente com formato de placas finas.

Os $\mathrm{Cr}_{2} \mathrm{~N}$ podem formar-se na ZAC durante o processo de soldagem dos aços inoxidáveis duplex e superduplex. A microestrutura formada consiste em grãos grandes de ferrita com uma quantidade baixa de austenita de widmanstätten e abundante precipitação de nitretos cúbicos do tipo $\mathrm{CrN}$, que também interferem na resistência à corrosão e na tenacidade ao impacto [34]. Razão pela qual a precipitação de nitretos é levada em consideração durante a soldagem.

$>$ Austenita secundária $\left(\gamma_{2}\right)$ : forma-se pela decomposição da ferrita após tratamentos térmicos ou processos de soldagem. Tal decomposição pode ocorrer em diferentes faixas de temperaturas, as quais governam os diferentes mecanismos de precipitação de $\gamma_{2}$. Aparentemente existem três mecanismos de formação [8]: 
○ Pela reação eutetóide: $\delta \rightarrow \sigma+\gamma$.

- Como precipitados de Widmanstätten.

- Por um processo similar ao da martensita.

A reação eutetóide é facilitada pela difusão rápida nas interfaces $\delta / \gamma$, a qual resulta em um típico produto eutetóide, composto por fase $\sigma$ e $\gamma_{2}$ precipitados nos contornos de grão da ferrita pré-existente. A transformação ocorre entre 700 e $900^{\circ} \mathrm{C}$ e é provocada pela precipitação de fase $\sigma$, que gera zonas empobrecidas de cromo e molibdênio, porém ricas em níquel que favorecem o formação de $\gamma_{2}$.

$\mathrm{Na}$ faixa de temperatura de 650 e $800^{\circ} \mathrm{C}$, onde a difusão é mais rápida, a austenita formou-se como precipitados de Widmanstätten com diferentes morfologias. Neste intervalo de temperatura a $\gamma_{2}$ obedece a uma relação de orientação do tipo Kurdjumov-Sachs, e também possui um teor de níquel maior do que a matriz ferrítica, evidenciando que na transformação houve um processo de difusão.

Em temperaturas abaixo de $650^{\circ} \mathrm{C}$, a $\gamma_{2}$ apresenta uma composição muito parecida com a matriz ferrítica, sugerindo que a transformação foi adifusional, similar á transformação martensítica [35].

> Fase R: também conhecida como fase de Laves, precipita em pequenas quantidades na faixa de temperatura de $550^{\circ} \mathrm{C}$ a $700^{\circ} \mathrm{C}$ [8]. É uma fase intermetálica rica em molibdênio, que precipita tanto intragranularmente como intergranularmente. Sua formação compromete a resistência à corrosão por pite, além de diminuir sua tenacidade ao impacto.

Nitretos $\pi$ : descobertos recentemente [36], os nitretos $\pi$ precipitam nos aços inoxidáveis duplex intergranularmente após longos tempos de tratamentos isotérmicos na temperatura de $600^{\circ} \mathrm{C}$. Fase rica em cromo e molibdênio, sua formação contribui à fragilização e diminuição da resistência a corrosão por pite do aço. 


\subsection{Processo de junção}

\subsubsection{Brasagem}

O processo de brasagem é um método importante na união de metais. Na indústria cumpre um rol importante pela sua simplicidade, além de ser um dos mais adequados processos para a união de materiais ferrosos e não ferrosos.

A American Welding Society (AWS) define brasagem como; um grupo de processos de soldagem que produz a coalescência de materiais pelo aquecimento dos mesmos a uma temperatura apropriada, utilizando-se um material de adição com temperatura "liquidus" superior a $450^{\circ} \mathrm{C}$ e inferior à temperatura "solidus" do material de base [3739]. Portanto, deve-se entender que a junção é feita acima dos $450^{\circ} \mathrm{C}$ sem a fusão do metal base.

Neste processo o metal de adição é distribuído na folga da junta através de fenômenos de molhamento, espalhamento e capilaridade generalizados como. Para garantir uma boa qualidade da junta brasada, é necessário o perfeito molhamento das faces a serem unidas pelo metal de adição líquido [37].

No processo as superfícies do material de base que formam a junta interatuam com o metal de adição fundido. Esta interação é controlada pela difusão do metal de adição diretamente nos grãos e contornos de grãos do metal de base pela dissolução da superfície da junta que será brasada. Esta dissolução, quando excessiva, aumenta a abertura da junta, resultando na diminuição da espessura do metal de base, podendo até causar furos, dependendo da espessura do metal base. Este fenômeno é conhecido como erosão. A extensão desta erosão pode ser de proporções microscópicas ou macroscópicas, dependendo basicamente dos elementos ligantes do metal de adição assim como do tempo e temperatura de brasagem. Por exemplo, metais de adição com boro como elemento de liga tem maior poder erosivo do que metais de adição com fósforo, devido principalmente ao menor raio atômico do boro e a sua maior difusividade no níquel. Da mesma maneira, a deformação no metal de base também exerce influência na erosão do 
mesmo, sendo bastante pronunciado o seu aumento para deformações menores que $10 \%$ [40].

\subsubsection{Principais métodos de brasagem}

Costuma-se designar os processos de brasagem segundo as fontes ou métodos de aquecimento. A predominância de processos automatizados governa a indústria, no entanto, processos manuais ainda estão disponíveis. De acordo com a AWS os processos que atualmente têm uma importante significância na indústria são: Brasagem por chama; Brasagem por indução; Brasagem por infravermelho; Brasagem por imersão; Brasagem em forno e Brasagem por resistência elétrica. $A$ figura 2.7 mostra os principais processo de brasagem.

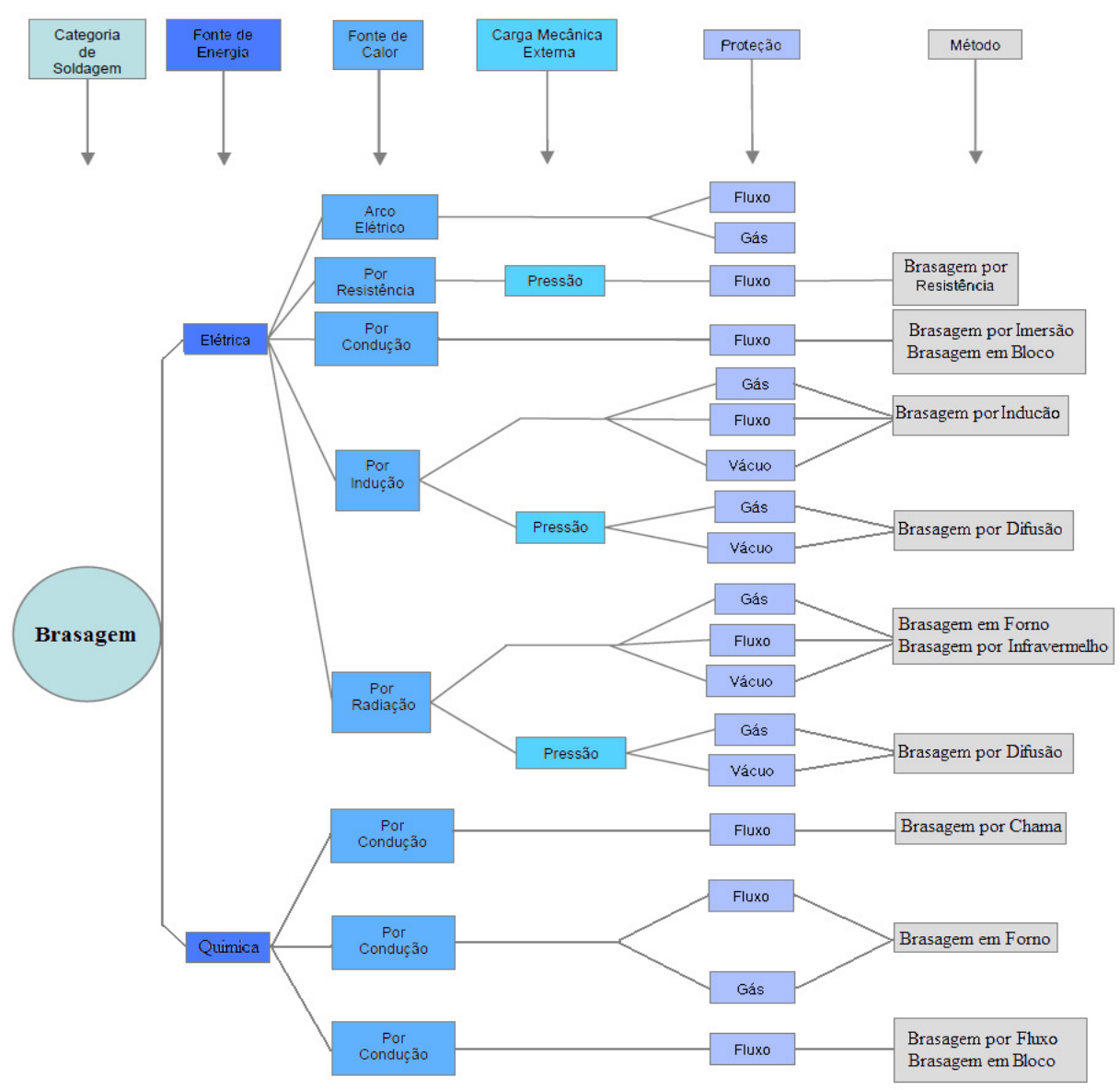

Figura 2.8 - Classificação dos Processos de Brasagem[37]. 
Serão agora detalhados os métodos de brasagem de mais uso para aços inoxidáveis.

\subsubsection{Brasagem por chama}

Processo bastante conhecido e frequentemente utilizado. A fonte de calor é obtida pela utilização de um ou mais maçaricos, que queimam misturas de um gás combustível (acetileno, GLP, propano, gás natural ou hidrogênio) com oxigênio ou raramente com ar. A seleção da mistura depende da quantidade de calor e temperatura necessárias para a operação.

A realização deste processo pode ser feita de forma totalmente manual, parcialmente mecanizada, ou integramente automatizada, sendo esta última utilizada quando a quantidade das peças ou conjuntos a serem soldados, oscila entre 400 a 1400 por hora.

Devido à facilidade de oxidação da superfície, precisa-se da utilização de um fluxo protetor, o qual pode estar na forma de pó, pasta, líquido ou uma mistura de pasta e metal de adição.

\subsubsection{Brasagem por indução}

Este processo consiste na geração de calor por uma corrente induzida através das peças a unir. No interior de uma bobina colocam-se as peças a serem unidas, a resistividade e o fluxo de corrente alternada no metal, provoca correntes parasitas, ou perdas pelo efeito Joule, o que resulta em um aquecimento rápido e concentrado [38].

Considera-se um processo relativamente simples e automático, não precisando de muita habilidade do operador. Assim como o processo por chama, o uso de fluxo e pré-posicionamento do metal de adição são necessários para este processo. Uma 
grande porcentagem dos metais podem ser brasados por este método com exceção do alumínio, magnésio e suas ligas.

\subsubsection{Brasagem em forno}

A alta produtividade e baixo custo de produção fizeram deste método um dos mais empregados na indústria, sendo conveniente para a brasagem de peças de dimensões médias. Problemas de aprisionamento de fluxo dentro da junta brasada motivou o desenvolvimento do processo de brasagem em forno [41].

Neste método, as peças a serem unidas e o metal de adição devem ser préposicionados e fixados antes de serem colocados no forno; o forno é aquecido a gás ou eletricidade, devendo-se ter um controle preciso da temperatura (tipicamente $\pm 6^{\circ} \mathrm{C}$ ) [37], bem como a distribuição do calor no interior do forno. A temperatura de aquecimento é fixada seguindo a natureza do metal base e de adição, podendo atingir até $1100^{\circ} \mathrm{C}$ de temperatura, quando se trata da brasagem de aços com ligas de cobre ou níquel como metal de adição. Considera-se uma temperatura relativamente alta se for comparada com as temperaturas convencionais de brasagem, que estão ao redor de $750^{\circ} \mathrm{C}$.

Para evitar que as peças sofram oxidação ou descarbonetação (no caso dos aços), são utilizadas atmosferas protetoras, sendo adicionado fluxo quando a atmosfera não é suficientemente efetiva. No caso da brasagem de aços inoxidáveis, para garantir que a atmosfera atue de forma protetora e permita que o metal de adição molhe o metal base, ela deve ser de caráter redutor.

Existem vários tipos de fornos usados para a brasagem, os dois básicos de maior uso são:

- Forno contínuo, mostrado esquematicamente na figura 2.9, as peças a serem brasadas são transportadas por meio de esteiras ou soleira de rolos através do forno aberto de três ou mais zonas de aquecimento. Durante a passagem das peças pelas diferentes zonas, uma atmosfera controlada é continuamente introduzida. Uma cortina de chama protege a entrada e saída do equipamento, quando se utiliza hidrogênio puro como atmosfera do forno. As 
peças, inicialmente, passam por uma zona de pré-aquecimento antes de chegar à zona de brasagem. Já na zona de brasagem, as peças são aquecidas até atingir a temperatura de fusão do material de adição e inferior à temperatura de fusão do material base. Por último as peças são resfriadas extraindo o calor por camisas de água mantendo a mesma atmosfera até a saída do forno.

Durante a brasagem neste tipo de forno, os parâmetros controlados para garantir uma união de qualidade são: velocidade de esteira, temperatura e atmosfera protetora.

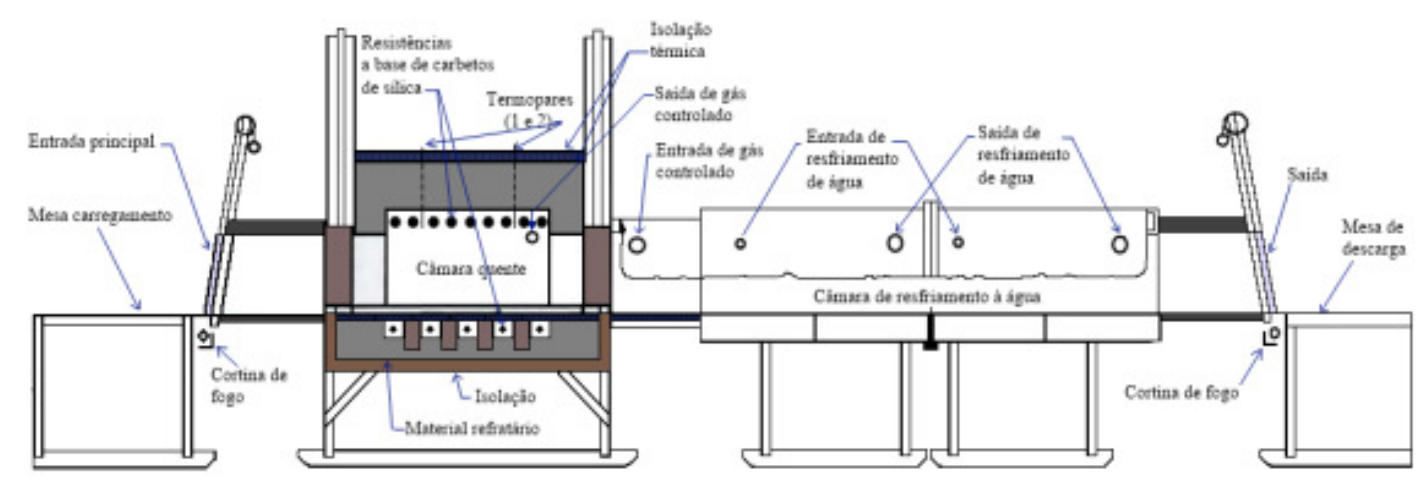

Figura 2.9 - Esquema de um forno contínuo para brasagem (Adaptado de [37]).

- Forno a vácuo, provavelmente um dos equipamentos para brasagem que proporciona um dos mais econômicos e efetivos ambientes disponíveis para a brasagem de materiais, que dificilmente conseguiriam brasar por outros meios. Os fornos a vácuo são invariavelmente aquecidos por eletricidade, seja qual for o tipo de forno. Neste tipo de equipamento as peças a serem brasadas são colocadas em uma câmara, onde posteriormente será produzido o vácuo e temperatura adequados para a realização da brasagem. Normalmente a pressão de vácuo usada na brasagem encontra-se na faixa de $0,13\left(1,3 \cdot 10^{-6}\right.$ bar) a $1,3 \mathrm{~Pa} \mathrm{Hg}\left(1,3 \cdot 10^{-5}\right.$ bar $)$. Um bombeamento contínuo garante a permanência de pressão de vácuo constante dentro da câmara. Existem dois tipos de equipamentos: fornos de parede quente e fornos de parede fria. Os fornos de paredes frias são de utilização mais frequente na indústria devido ao maior controle na taxa de resfriamento e as altas temperaturas de brasagem alcançadas $\left(2200^{\circ} \mathrm{C}\right)$. Nos fornos de parede fria 
os elementos de aquecimento e isolamento se encontram no interior do mesmo, além da câmara ser resfriada por água.

\subsubsection{Variáveis do processo}

\subsubsection{Tensões superficiais e ângulo de contato}

O fenômeno da tensão superficial está diretamente ligado à interação de forças atrativas existentes entre as diferentes partículas de um líquido. Uma partícula no interior do líquido experimenta por parte das partículas vizinhas forças atrativas agindo de igual forma em todas as direções e cuja resultante é praticamente nula. Entretanto, as partículas que se encontram na superfície apenas interagem com as partículas vizinhas do interior do líquido determinando uma resultante dirigida para o centro do líquido. A figura 2.10 apresenta esquematicamente estas definições.
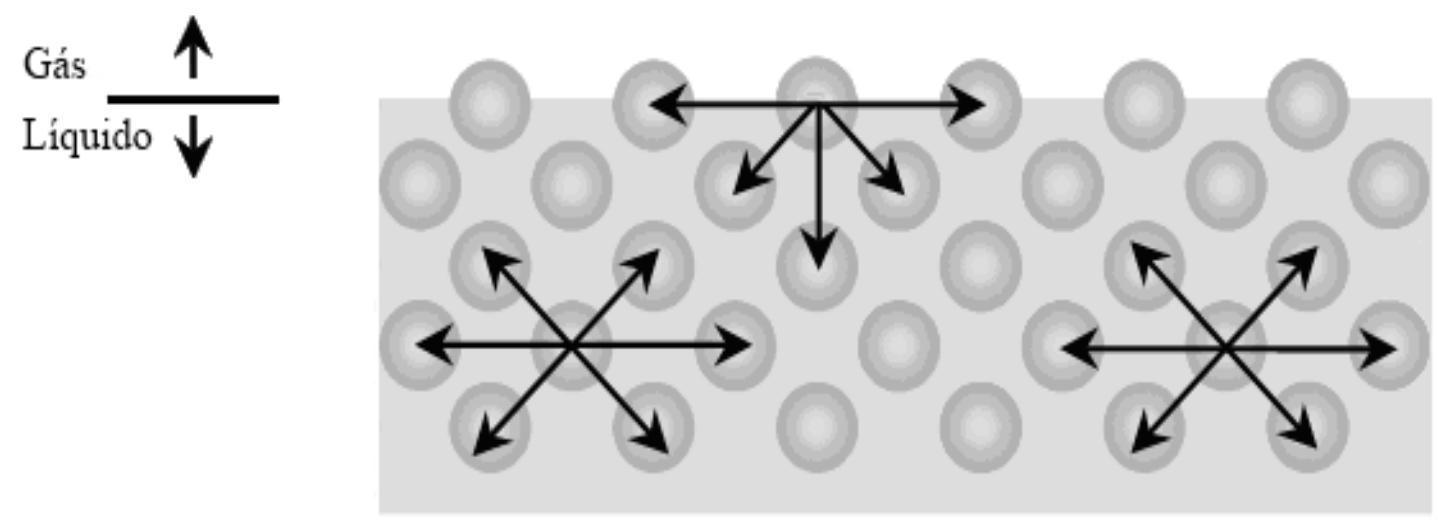

Figura 2.10 - Forças de atração entre partículas da superfície e do interior de um líquido, para uma interface plana líquido-vapor.

São definidas três interfaces no caso de uma gota líquida em equilíbrio molhando um substrato sólido: interface sólido-vapor, interface líquido-vapor, interface sólidolíquido. A linha comum às três interfaces é chamada de linha de contato e o ângulo 
formado entre a interface líquido-vapor e o substrato sólido é chamado de ângulo de contato, conforme mostra esquematicamente a figura 2.11 .

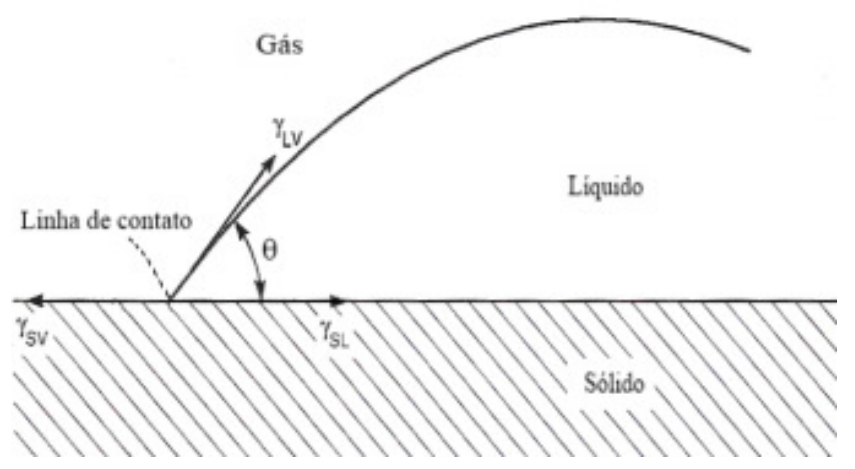

Figura 2.11 - Esquema das interfaces presentes em uma gota de um líquido em um substrato sólido circuncidado por um gás com as respectivas tensões superficiais[37].

O valor do ângulo de contato define o grau de molhabilidade de um líquido sobre um substrato sólido. Desta forma, se o ângulo formado entre a interface líquido-vapor e o substrato for maior do que $90^{\circ}$, se estabelece que não existe "molhamento" por parte do líquido sobre o substrato, no entanto, se o ângulo formado for menor do que $90^{\circ}$, se diz que o líquido molhou o substrato. Quando o ângulo de contato for igual à zero, considera-se a condição de molhamento ideal, em razão ao total espalhamento do líquido sobre o substrato (Figura 2.12).

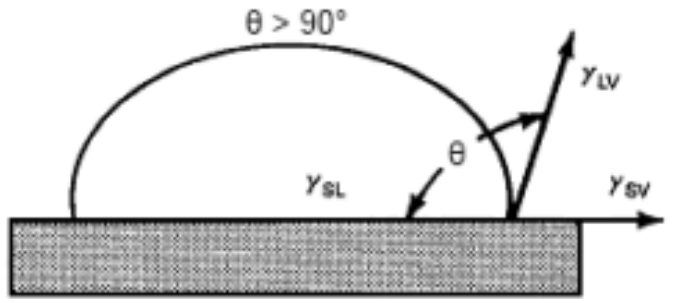

(a)

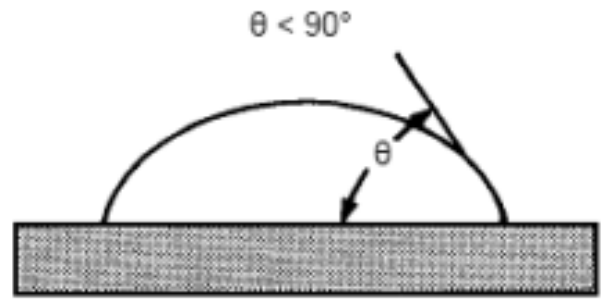

(b)

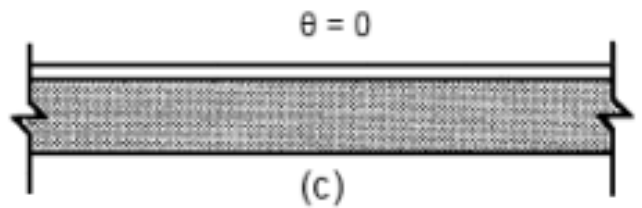

Figura 2.12 - Ângulo de contato $\theta$ para uma gota líquida sobre um substrato sólido: (a) $>90^{\circ},(b)<90^{\circ}$, e (c) $\theta=90^{\circ}$ [42]. 
O ângulo de contato pode ser calculado através da clássica equação de YoungDupré, cuja dedução física obedece ao balanço das tensões superficiais sempre e quando estas tensões sejam assumidas como forças (ver Figura 2.11), portanto:

$$
\gamma_{s v}-\gamma_{s l}=\gamma_{l v} \cos \theta
$$

Também é possível fazer a dedução da equação de Young-Dupré desde o ponto de vista termodinâmico a partir da equação da Energia Livre de Helmholtz (F) [43]. Para isto devem-se levar em conta algumas considerações importantes, como o volume e temperatura devem-se manter constantes [44].

$$
F=E-T * S
$$

Diferenciando a equação (2) transforma-se em:

$$
d F=d E-T * d S-S * d T
$$

Como a temperatura é constante:

$$
d F=d E-T * d S
$$

A energia interna de um sistema aberto pode ser expressa por:

$$
d E=T d S-p_{1} d V_{1}-p_{2} d V_{2}-\rho g d H+\Sigma_{i} \mu_{i} d n_{i}+\Sigma_{i} \gamma_{i} d A_{i}+k_{1} d c_{1}+k_{2} d c_{2}
$$

A expressão da energia livre de Helmholtz torna-se:

$$
d F=-p_{1} d V_{1}-p_{2} d V_{2}-\rho g d H+\Sigma_{i} \mu_{i} d n_{i}+\Sigma_{i} \gamma_{i} d A_{i}+k_{1} d c_{1}+k_{2} d c_{2}
$$

Assumindo que não existe o efeito do campo gravitacional na gota $(\rho g \mathrm{dH}=0)$, o formato da calota da gota sobre o substrato sólido é perfeitamente esférica $\left(\mathrm{d}\left(\mathrm{c}_{1}\right.\right.$ $\left.c_{2}\right)=0$ ) e não existe variação de volume do líquido, a equação da energia livre de Helmholtz transforma-se em:

$$
\begin{aligned}
& d F=\Sigma_{i} \mu_{i} d n_{i}+\Sigma_{i} \gamma_{i} d A_{i}=\mu\left(d n_{l v}+d n_{s v}+d n_{s l}\right)+\mu\left(d n_{s}+d n_{l}+d n_{v}\right)+\gamma_{s v} d A_{s v}+ \\
& \gamma_{s l} d A_{s l}+\gamma_{l v} d A_{l v}
\end{aligned}
$$

Admitindo-se que o número de mols permanece constante:

$$
d n_{l v}+d n_{s v}+d n_{s l}+d n_{s}+d n_{l}+d n_{v}=d n_{T}=0
$$

A equação (7) transforma-se em:

$$
d F=\gamma_{s v} d A_{s v}+\gamma_{s l} d A_{s l}+\gamma_{l v} d A_{l v}
$$

Se o crescimento da área $A_{s v}$ for igual ao consumo da área $A_{s l}$, então:

$$
d A_{s l}=-d A_{s v}
$$

Supondo que a gota tem formato de uma calota esférica: 


$$
d A_{l v}=d A_{s l} \cos \theta
$$

A equação (9) assume a forma:

$$
d F=\left(-\gamma_{s v}+\gamma_{s l}+\gamma_{l v} \cos \theta\right) d A_{s l}
$$

A variação de energia livre de Helmholtz deve ser mínima com relação à variação de área $A_{\mathrm{sl}}$ :

$$
\left(d F / d A_{s l}\right)=-\gamma_{s v}+\gamma_{s l}+\gamma_{l v} \cos \theta=0
$$

Portanto:

$$
\cos \theta=\frac{\gamma_{s v}-\gamma_{s l}}{\gamma_{l v}}
$$

Conforme foi mencionado anteriormente, o grau de molhabilidade de um substrato pode ser quantificado pelo ângulo de contato $\theta$, sendo que, quanto mais próximo de zero estiver $\theta$ melhor será o molhamento do substrato, deste modo, fazendo uma análise da equação (14) a diminuição de $\theta$ pode ser obtida por [45]:

- Aumento de $\gamma_{\mathrm{sv}}$

- Diminuição de $\gamma_{\mathrm{lv}}$

- Diminuição de $\gamma_{\mathrm{sl}}$

O aumento do termo $\gamma_{\mathrm{sv}}$ para um dado substrato pode ser atingido através da limpeza da superfície, por outro lado, o termo $\gamma_{\mathrm{lv}}$ pode variar com a alteração da composição e pressão da atmosfera e o termo $\gamma_{\mathrm{sl}}$ geralmente diminui com o aumento da temperatura [45]. Porém, um adequado controle na atmosfera (seja redutora ou vácuo) e na temperatura, assim como, a eliminação de materiais absorvidos, tais como óxidos, vapor de água e outros tipos de impurezas melhoram o molhamento de um substrato. 


\subsubsection{Espalhamento}

O molhamento é resultado do comportamento cinético que tem certo líquido pousado sobre uma superfície sólida, mais precisamente, trata-se da interação energética existente entre as energias de superfície até que seja atingida uma condição de equilíbrio.

A abordagem deste fenômeno pode ser apresentada termodinamicamente [46-47], como hidrodinamicamente [48]. Desde o ponto de vista termodinâmico o espalhamento acontece com a diminuição da energia livre de Helmholtz. Isso significa que o coeficiente de espalhamento de um líquido na superfície de um sólido é definido como [44]:

$$
S_{l / s}=\gamma_{s v}-\gamma_{s l}-\gamma_{l v}
$$

Assim, a equação (15) mostra que para consumir a interface SV precisa-se o mesmo trabalho que para criar as interfaces SL e LV.

Como no equilíbrio a energia livre de Helmholtz tende a zero, o coeficiente de espalhamento é positivo, mostrando que a soma de $\gamma_{\mathrm{sl}}$ e $\gamma_{\mathrm{lv}}$ será menor que $\gamma_{\mathrm{sv}}$. Já com o coeficiente de espalhamento negativo a soma de $\gamma_{s l}$ e $\gamma_{l_{v}}$ será maior que $\gamma_{s v}$.

Por outro lado, a abordagem hidrodinâmica leva em consideração fluidos de alta viscosidade sobre substratos não metálicos [44].

\subsubsection{Capilaridade}

Considerado um dos princípios físicos mais importantes e que rege o processo de brasagem, a capilaridade define-se como a força que atua sobre um líquido confinado entre duas superfícies sólidas paralelas, separadas por uma distância muito pequena. Estas forças estão diretamente ligadas às tensões superficiais, resultantes da interação entre o líquido e as superfícies sólidas (molhagem do substrato), e também as características físicas como o tamanho do espaçamento de folga. 
A ação das forças capilares vê-se afetada com o espaçamento entre superfícies, existindo um valor limite deste espaçamento para que aconteça o fenômeno de capilaridade. O percurso de um líquido dentro de duas superfícies aumenta com a diminuição da distância entre elas.

\subsection{Metal de adição}

Uns dos aspectos críticos e de alta importância na brasagem de materiais, é a escolha do metal de adição, para garantir uma junta com características adequadas a uma dada aplicação.

Existem diversos tipos de metais de adição comercialmente disponíveis para a brasagem dos aços inoxidáveis. Porém, para fazer uma escolha que atenda os requerimentos de uma determinada aplicação, deve-se considerar os seguintes fatores [42]:

- Possibilidade de interação com o metal de base;

- Condição de serviço que inclui temperatura de trabalho, esforço que será submetido, ambiente de trabalho;

- Processo de brasagem;

- Temperatura de brasagem;

- Exigências de tratamento térmico;

- Custo;

- Precauções especiais, tais como, sensitização dos aços inoxidáveis para determinadas temperaturas.

Considerando as propriedades dos aços inoxidáveis duplex e os fatores acima mencionados, é possível mencionar que as ligas a base de níquel são adequadas para a brasagem destes materiais devido à faixa de temperatura de fusão. 


\subsubsection{Metais de adição a base de níquel}

Os metais de adição a base de níquel são frequentemente utilizados para a brasagem de aços inoxidáveis, visto que, proporcionam juntas com excelente resistência à corrosão e ao calor [37]. Além de possuir elevada resistência em altas temperaturas, também apresentam boas propriedades em ambientes criogênicos onde as temperaturas de serviço são tão baixas quanto à do nitrogênio líquido [38]. Por causa das temperaturas relativamente elevadas necessárias para a brasagem deste tipo de adição, é preciso o uso de atmosferas redutoras para obter juntas com boas qualidades. A realização da brasagem em forno com atmosfera controlada é um dos mais sugeridos. No entanto, a brasagem por métodos sem atmosfera controlada também é possível, desde que seja incorporada a utilização de fluxo.

Estes metais de adição são classificados pela AWS (American Welding Society) com a notação de $\mathrm{BNi}$, seguido de um número que se refere a composição química da adição. As ligas à base de níquel apresentam, geralmente, na sua composição química como principais elementos de liga o cromo, silício, boro e fósforo. A tabela 2.5 apresenta a composição das ligas de níquel para brasagem segundo a norma AWS A5.8-92 [49].

Tabela 2.5 - Composição química de metais de adição BNi segundo a norma AWS A5.8-92[49].

\begin{tabular}{|c|c|c|c|c|c|c|c|c|}
\hline \multirow{2}{*}{$\begin{array}{c}\text { Classificação } \\
\text { AWS }\end{array}$} & \multicolumn{7}{|c|}{ Composição Química } \\
\cline { 2 - 10 } & $\mathbf{C r}$ & $\mathbf{B}$ & $\mathbf{S i}$ & $\mathbf{F e}$ & $\mathbf{C}$ & $\mathbf{P}$ & $\mathbf{M n}$ & W \\
\hline $\mathrm{BNi}-1$ & $13,0-15,0$ & $2,75-3,50$ & $4,0-5,0$ & $4,0-5,0$ & $0,60-0,90$ & 0,02 & - & - \\
\hline $\mathrm{BNi}-1^{\mathrm{a}}$ & $13,0-15,0$ & $2,75-3,50$ & $4,0-5,0$ & $4,0-5,0$ & 0,06 & 0,02 & - & - \\
\hline $\mathrm{BNi}-2$ & $6,0-8,0$ & $2,75-3,50$ & $4,0-5,0$ & $2,5-3,5$ & 0,06 & 0,02 & - & - \\
\hline $\mathrm{BNi}-3$ & - & $2,75-3,50$ & $4,0-5,0$ & 0,5 & 0,06 & 0,02 & - & - \\
\hline $\mathrm{BNi}-4$ & - & $1,50-2,20$ & $3,0-4,0$ & 1,5 & 0,06 & 0,02 & - & - \\
\hline $\mathrm{BNi}-5$ & $18,5-19,5$ & 0,03 & $9,75-10,50$ & - & 0,06 & 0,02 & - & - \\
\hline $\mathrm{BNi}-5^{\mathrm{a}}$ & $18,5-19,5$ & $1,0-1,5$ & $7,0-7,5$ & 0,5 & 0,1 & 0,02 & - & - \\
\hline $\mathrm{BNi}-6$ & - & - & - & - & 0,06 & $10,0-12,0$ & - & - \\
\hline $\mathrm{BNi}-7$ & $13,0-15,0$ & 0,01 & 0,1 & 0,2 & 0,06 & $9,7-10,5$ & - & - \\
\hline $\mathrm{BNi}-8$ & - & - & $6,0-8,0$ & - & 0,06 & 0,02 & $21,5-24,5$ & - \\
\hline $\mathrm{BNi}-9^{*}$ & $13,5-16,5$ & $3,25-4,00$ & - & 1,5 & 0,06 & 0,02 & - & - \\
\hline $\mathrm{BNi}-10$ & $10,0-13,0$ & $2,0-3,0$ & $3,0-4,0$ & $2,5-4,5$ & $0,40-0,55$ & 0,02 & - & $11,5-12,75$ \\
\hline $\mathrm{BNi}-11$ & $9,0-11,75$ & $2,2-3,1$ & $3,35-4,25$ & $2,5-4,0$ & $0,30-0,50$ & 0,02 & - & $3,5-4,5$ \\
\hline
\end{tabular}

$\left({ }^{*}\right) \mathrm{Cu}=4,0$ a 5,0 
A temperatura de brasagem de cada uma destas adições é função da composição química das mesmas. Mostra-se na tabela 2.6 as temperaturas solidus, liquidus e de brasagem para cada uma das adições à base de níquel.

Tabela 2.6 - Temperaturas liquidus, solidus e faixa de temperatura recomendada para brasagem de ligas à base de níquel, segundo AWS A5.8-92 [49].

\begin{tabular}{|c|c|c|c|}
\hline $\begin{array}{c}\text { Classificação } \\
\text { AWS }\end{array}$ & $\begin{array}{c}\text { Solidus } \\
\left(\mathbf{C}^{\circ}\right)\end{array}$ & $\begin{array}{c}\text { Liquidus } \\
\left(\mathbf{C}^{\circ}\right)\end{array}$ & $\begin{array}{c}\text { Intervalo temperatura de brasagem } \\
\left(\mathbf{C}^{\circ}\right)\end{array}$ \\
\hline $\mathrm{BNi}-1$ & 977 & 1038 & $1066-1204$ \\
\hline $\mathrm{BNi}-1^{\mathrm{a}}$ & 977 & 1077 & $1077-1204$ \\
\hline $\mathrm{BNi}-2$ & 971 & 999 & $1010-1177$ \\
\hline $\mathrm{BNi}-3$ & 982 & 1038 & $1010-1177$ \\
\hline $\mathrm{BNi}-4$ & 982 & 1066 & $1010-1177$ \\
\hline $\mathrm{BNi}-5$ & 1079 & 1135 & $1149-1204$ \\
\hline $\mathrm{BNi}-5^{\mathrm{a}}$ & 1065 & 1150 & $1149-1204$ \\
\hline $\mathrm{BNi}-6$ & 877 & 877 & $927-1093$ \\
\hline $\mathrm{BNi}-7$ & 888 & 888 & $927-1093$ \\
\hline $\mathrm{BNi}-8$ & 982 & 1010 & $1010-1093$ \\
\hline $\mathrm{BNi}-9$ & 1055 & 1055 & $1066-1204$ \\
\hline $\mathrm{BNi}-10$ & 970 & 1105 & $1066-1204$ \\
\hline $\mathrm{BNi}-11$ & 970 & 1095 & $1149-1204$ \\
\hline
\end{tabular}

\subsubsection{Efeito dos elementos de liga nas adições à base de níquel para brasagem}

A presença dos elementos de liga nas adições à base de níquel proporciona características adequadas para a brasagem dos aços inoxidáveis.

Tabela 2.7 - Efeito dos elementos de liga nas propriedades das adições de níquel para brasagem [50].

\begin{tabular}{|c|c|}
\hline PROPRIEDADE & METAL \\
\hline Resistência mecânica & $\mathrm{Ni}, \mathrm{Co}, \mathrm{Cr}$ \\
\hline Resistência à oxidação & $\mathrm{Cr}, \mathrm{Co}, \mathrm{Ni}, \mathrm{Pd}, \mathrm{Au}, \mathrm{Si}, \mathrm{W}$ \\
\hline Depressor do ponto de fusão & $\mathrm{B}, \mathrm{Si}, \mathrm{Mn}, \mathrm{C}, \mathrm{P},(\mathrm{Ge}),(\mathrm{Sn})$ \\
\hline Erosividade & $\mathrm{B}, \mathrm{Si}, \mathrm{P}$ \\
\hline
\end{tabular}


$\mathrm{Na}$ continuação serão discutidos os efeitos dos principais elementos de liga nas adições para brasagem:

- Boro, a presença deste elemento nas adições a base de níquel e em outras adições para brasagem, tem como principal função; atuar como depressor da temperatura liquidus da liga. Comparada com a temperatura de fusão do níquel puro $\left(1455^{\circ} \mathrm{C}\right)$, a linha liquidus pode ser reduzida consideravelmente com a adição de boro. $O$ efeito do boro na diminuição da temperatura é que combinado com o níquel tende a formar eutéticos com baixos pontos de fusão (Figura 2.13). Não obstante a permanência destes eutéticos na junta brasada promove pontos de fragilidade e limitação de temperatura máxima de serviço. Outro efeito do boro nas diferentes adições para brasagem é sua habilidade de conceder propriedades auto-fluxantes. A proporção de boro nas adições para brasagem sempre é menor do que $5 \%[37,53]$.

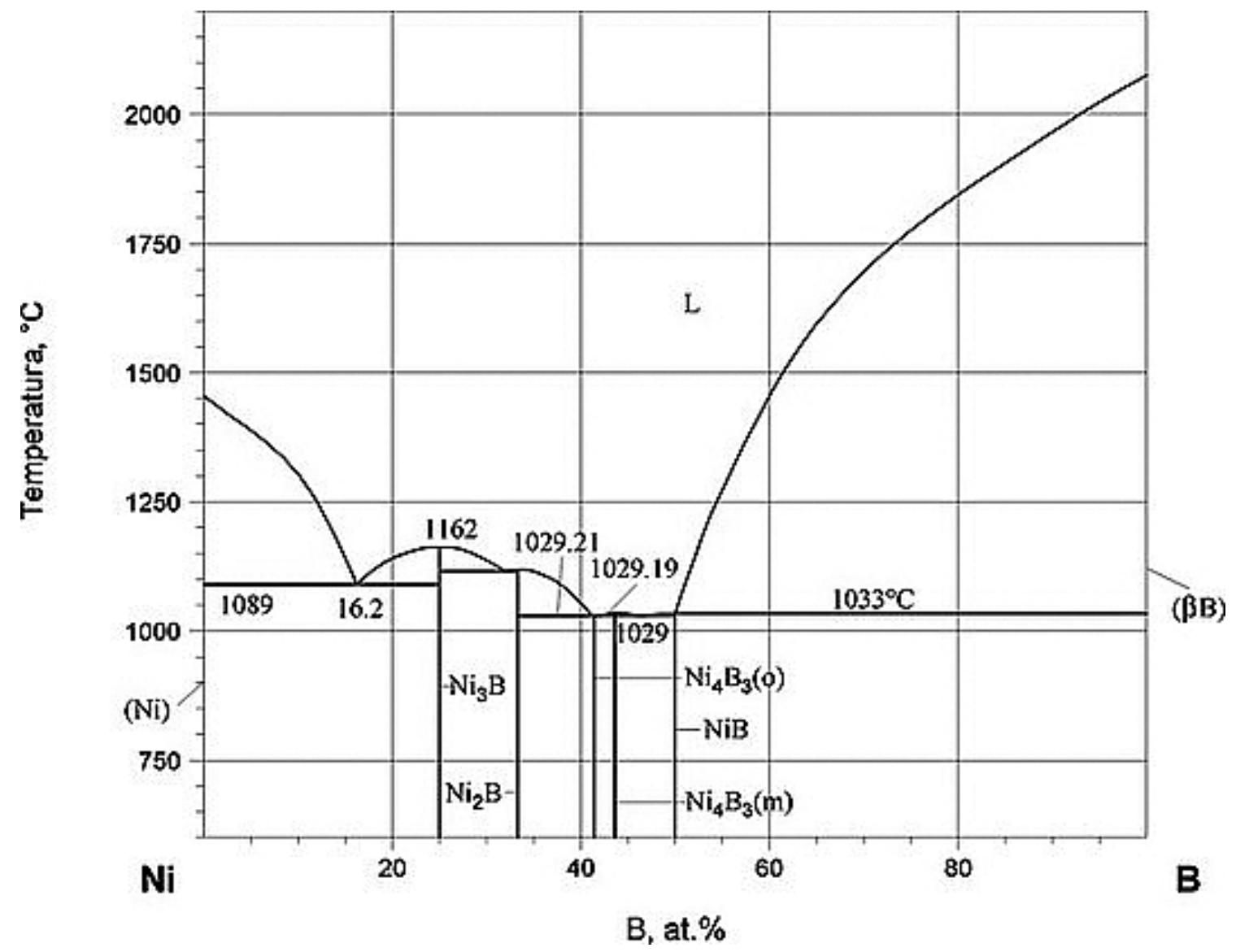

Figura 2.13 - Seção de diagrama de fases $\mathrm{Ni}$ - B [51]. 
- Silício, considerado como um dos mais importantes depressores de temperatura durante o início do desenvolvimento das ligas a base de níquel[52]. O silício também proporciona propriedades auto-fluxantes. Em combinação com o boro formam silicatos, os quais dissolvem óxidos de $\mathrm{Fe} \mathrm{e}$ $\mathrm{Ni}$. Isto se torna importante durante a utilização de ligas à base níquel, já que a escória de B-Si age como fluxo, garantindo uma melhor molhagem da adição sobre o metal base.

Problemas de erosividade também são atribuídos a este elemento, mas são menos acentuados do que o boro. Por apresentar tamanho de átomo maior a difusividade do silício é baixa, típico dos átomos substitucionais. Os compostos formados pelo silício são menos estáveis do que os boretos e não são formados preferencialmente. Em adições para brasagem é usado em associação ao boro, diminuindo a proporção do boro e, portanto os efeitos prejudiciais associados a este elemento.

- Fósforo, considerado como um forte depressor da temperatura liquidus [53]. Este elemento quando combinado com o níquel produz eutéticos com baixos pontos de fusão. De forma geral a presença do fósforo nos metais de adição tem um efeito benéfico na fluidez e, portanto no molhamento [53-54], além de apresentar uma aparência muito boa. Ao contrário do boro e silício, o fósforo produz uma liga com boas propriedades de brasagem ao ser ligado unicamente com o níquel. Entretanto, o fósforo forma com o níquel compostos intermetálicos, que em porcentagens consideráveis, afeta a resistência mecânica da junta, tornando-a frágil e reativa [53-55], não apresentando as propriedades requeridas para aplicações em altas temperaturas. $O$ teor de fósforo em ligas à base níquel encontra-se na faixa de 10 a $12 \%$.

- Cromo, a adição deste elemento nas ligas para brasagem tem como objetivo acrescentar a resistência mecânica e à corrosão, em ligas com níquel ou cobalto forma soluções sólidas bastante dúcteis. Por possuir um ponto de fusão bastante elevado o cromo pode ser adicionado em quantidades de até $20 \%$ às ligas $\mathrm{Ni}$-Si e Ni-Si-B, sem alterar consideravelmente a temperatura de fusão das ligas além dos limites práticos. 
- Manganês, a tenacidade de ligas estruturais vê-se favorecida com a adição deste elemento, concedida principalmente por endurecimento por solução sólida. O manganês também atua como depressor da temperatura de fusão e, tende a baixar a tensão superficial e melhorar a fluidez da liga. Produto das vantagens oferecidas, o manganês vem sendo utilizado em alguns dos metais de adição mais recentes.

- Ferro, geralmente considerado um elemento neutro que é adicionado inadvertidamente às ligas para brasagem, com a adição de boro e/ou silício. O elevado ponto de fusão do ferro promove um leve aumento na temperatura de fusão da liga. A resistência à oxidação também se vê afetada na presença deste elemento. Considerado como uma impureza relativamente sem efeito.

- Carbono, considerado um elemento indesejável na maioria das ligas para brasagem, devido a sua afinidade de formar compostos intermetálicos como carbonetos de cromo, os quais têm efeito negativo na resistência à corrosão da liga. Como o ferro é considerado uma impureza.

\subsubsection{Folga da junta}

Considera-se de grande importância o rol que desempenha a folga da junta nas propriedades mecânicas, assim como a influência que exerce sobre as forças de capilaridade, a qual está diretamente relacionada com o grau de preenchimento da união.

O projeto de uma folga adequada para uma junta brasada depende basicamente de variáveis como: tipo de fluxo, acabamento superficial do conjunto a ser brasado, interação entre o metal de base e metal de adição, metal base, metal de adição e do tipo de processo de brasagem que será usado [37]. 
De forma geral, a resistência da junta brasada vê-se afetada com o tamanho da folga, sendo uma relação inversamente proporcional. Quanto menor o tamanho da folga maior será a resistência da junta. Este fato, explica-se pela melhor distribuição do metal de adição na junta pelas forças capilares em folgas pequenas. Segundo alguns estudiosos, a folga ideal de trabalho para atingir resistência mecânica elevada encontra-se na faixa de 0,05 a 0,13 mm como é mostrado na figura 2.14 [37].

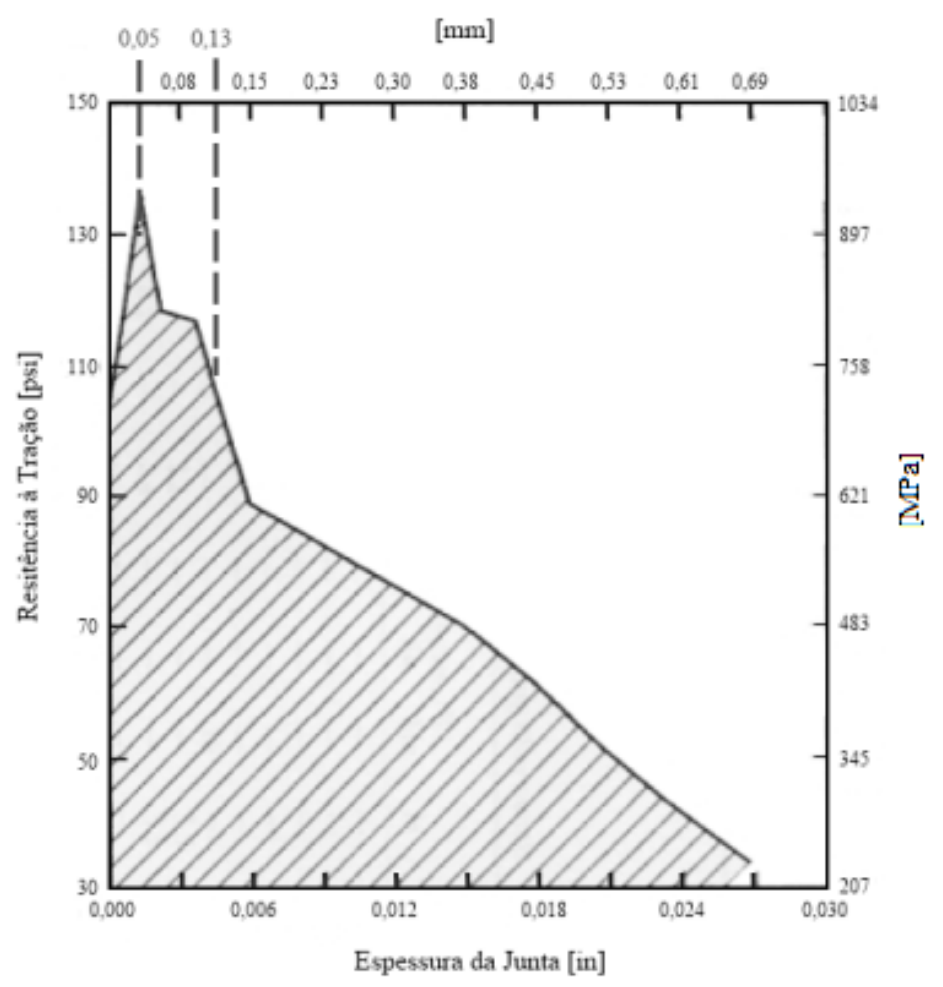

Figura 2.14 - Esquema da presença de folga ideal em função de resistência ao cisalhamento da junta[37].

As diversas variáveis envolvidas na brasagem fazem com que o dimensionamento de folgas de junta apresente certas dificuldades. Sendo as variáveis de importância que afetam no comprimento da folga: tipo de fluxo ou atmosfera usados, interação entre o metal de adição e metal base, fluidez do metal de adição, faixa de temperatura de fusão, tanto do metal de adição como do metal base [38].

Outra consideração importante na hora do dimensionamento da folga é o coeficiente de expansão térmica dos metais de base que serão unidos. Já que a junção de materiais com uma pronunciada diferença provocará uma junta com folga muito 
diferente na temperatura de brasagem, o que induzirá posteriormente a se ter uma junta com tensões residuais [37-38].

Para folgas com dimensões muito pequenas podem-se encontrar problemas de preenchimento devido ao aprisionamento de fluxo, o qual permanece fortemente aderido às superfícies evitando a entrada de metal fundido, interferindo nas propriedades mecânicas por falhas de preenchimento da junta [22-25].

A formação de fases intermetálicas também está em função da dimensão da folga da junta. Estas podem se formar tanto no centro como na interface sólido/líquido do metal de junta. A relação de formação de fases intermetálicas é diretamente proporcional ao tamanho de folga, isto quer dizer que quanto maior a folga, maior a probabilidade de formar fases intermetálicas.

Portanto, o dimensionamento de folgas deve ser respeitado para que, deste modo, deixem as juntas isentas de defeitos como: deficiente espalhamento de metal de adição, formação de intermetálicos ao longo da junta brasada ou a inclusão de fluxo, que posteriormente comprometerão o desempenho da junta.

\subsubsection{Atmosferas para brasagem}

Frequentemente utilizadas na brasagem em altas temperaturas, as atmosferas controladas previnem a formação de compostos simples ou complexos de sulfetos, boretos, fosfetos, mas principalmente evita a formação de camadas de óxidos nas superfícies a serem unidas. Com a remoção das camadas de óxidos o metal de adição fundido escoa e molha com maior facilidade o metal de base.

A temperatura com a qual um óxido é dissociado depende diretamente da pressão parcial do oxigênio na atmosfera, portanto, a compreensão da relação entre o ponto de orvalho da atmosfera e a temperatura de brasagem serve para prever a atmosfera de brasagem necessária para um determinado processo [37-38]. Foram 
desenvolvidas curvas para diversos metais considerando a relação de temperatura e ponto de orvalho da atmosfera, conforme apresenta a figura 2.15.

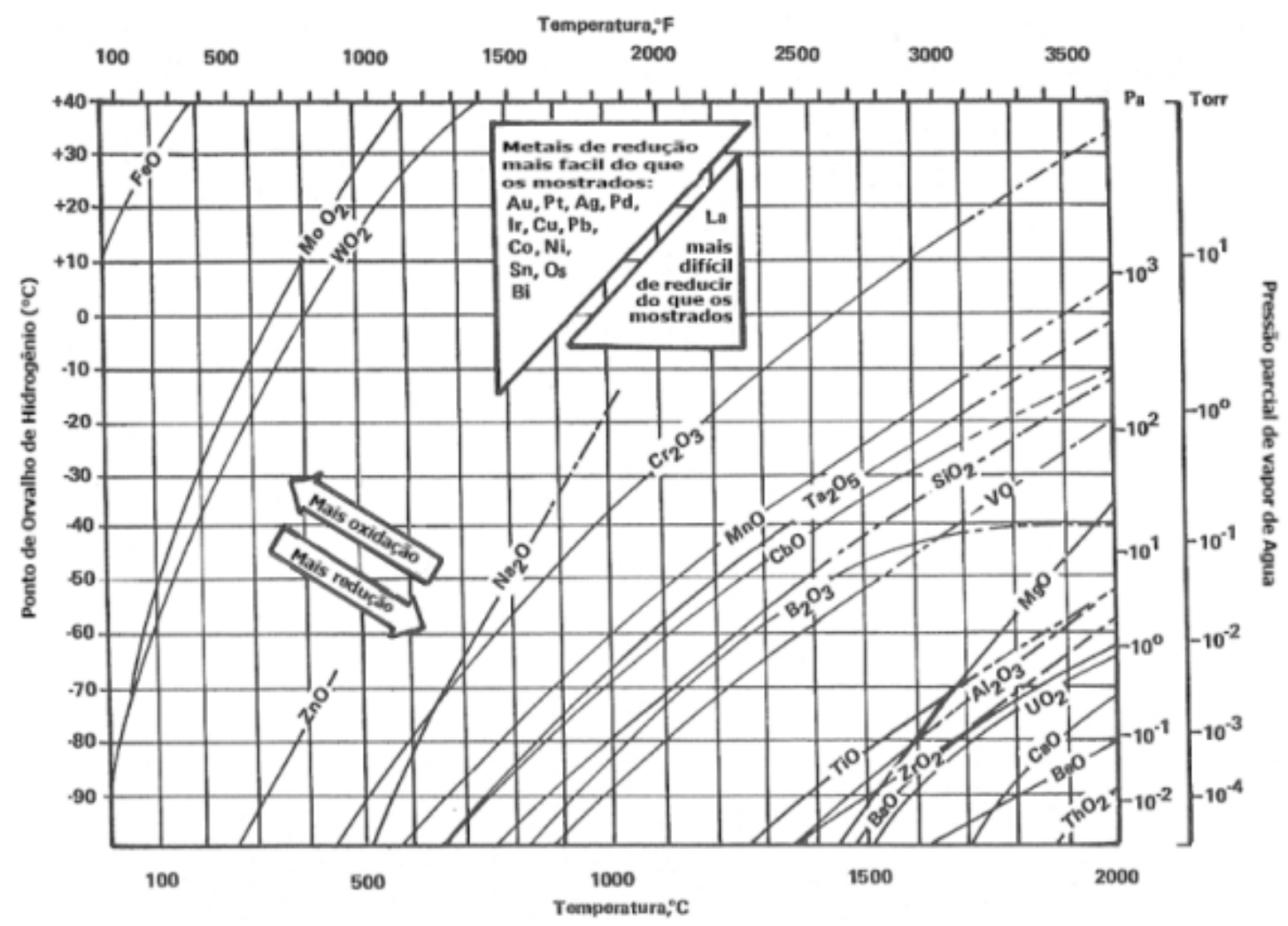

Figura 2.15 - Relação entre oxidação e redução de óxido em função do ponto de orvalho e da temperatura [37].

Pode-se deduzir da figura 2.15 que, a redução de um óxido será obtida quando a combinação de temperatura de brasagem e ponto de orvalho se encontram a direita e embaixo da curva de oxidação do metal.

$\mathrm{Na}$ brasagem de aços inoxidáveis é bastante comum a utilização de atmosferas gasosas redutoras ou a vácuo, sendo as atmosferas de amônio $\left(\mathrm{NH}^{+}\right)$e hidrogênio as mais utilizadas em fornos contínuos. Mostrando-se preferencialmente mais usadas as atmosferas de hidrogênio devido a sua facilidade para reduzir óxidos de cromo. 


\subsection{Microestrutura de junta brasada}

O desenvolvimento de uma junta brasada que apresenta uma qualidade elevada é refletida pelas suas propriedades mecânicas> No caso dos aços inoxidáveis a resistência à corrosão da união deve ser superior ao metal de base. Como as propriedades da junta brasada estão fortemente ligadas a sua microestrutura, e esta por sua vez, é determinada por diversos fatores, dentre os quais se podem mencionar: a composição química do metal de adição, o limite de solubilidade do metal de adição no metal base, o tempo de brasagem e a folga da junta. Existe uma razão entre estes fatores que garante uma microestrutura da junta com o máximo do seu desempenho [56]. Esta microestrutura, de uma maneira geral, é composta basicamente de uma junta composta de uma solução sólida contínua, sem a presença de fases intermetálicas contínuas no centro da junta.

\subsubsection{Efeito da composição química}

A variação de elementos de liga nos metais de adição a base níquel promovem a formação de diferentes compostos intermetálicos tanto na linha central da junta como nas interfaces durante a brasagem. Como foi discutido anteriormente são os elementos depressores de temperatura como: boro, silício e fósforo, os principais formadores de compostos intermetálicos. Estes elementos desenvolvem junto com o níquel e o cromo, compostos intermetálicos e estruturas eutéticas extremamente duras e frágeis. Na microestrutura da junta brasada aparecem como fases frágeis na forma de boretos, silicatos e fosfatos [57]. A formação destes compostos depende da temperatura e tempo de brasagem. 


\subsubsection{Efeito da temperatura}

Dos diferentes fatores que têm um pronunciado efeito no desenvolvimento da microestrutura da junta brasada é talvez a temperatura de brasagem que desempenha um papel importante [58]. A brasagem, assim como outros tantos processos de união de materiais, está regida pelo fenômeno da difusão. A temperatura é um fator que atua diretamente na velocidade de difusão de um dado elemento.

Na brasagem em alta temperatura é comum observar interdifusão de elementos de liga entre o metal de base e o metal de adição fundido, especialmente os elementos depressores da temperatura liquidus [59]. A profundidade de enriquecimento de elementos provenientes do metal de adição fundido, a partir da interface entre o metal de base e o metal de adição em um tempo constante, será consequência direta da temperatura de brasagem. Este fenômeno causa a mudança na composição química do metal de adição, promovendo subsequentemente a solidificação isotérmica da junta [60]. Isto significa, que quanto maior a temperatura de brasagem menor será a formação de estruturas eutéticas promovidas pelos elementos depressores de temperatura [58], desde que, a temperatura esteja na faixa de brasagem da adição.

Outro efeito significativo é a influência da temperatura no aumento do tamanho da folga livre de compostos intermetálicos frágeis, conforme foi documentado no trabalho de Lugscheider [61]. Conforme aumentava-se a temperatura, a de folga isenta de fases frágeis também aumentava.

\subsubsection{Efeito do tempo}

Assim como a temperatura, o tempo é outro fator que atua na interdifusão de elementos entre o metal de adição e o metal de base. Seu efeito está relacionado 
com a precipitação de fases e a dissolução do metal de base durante o ciclo de brasagem. O tempo de permanência na temperatura de brasagem definirá o volume de metal base dissolvido, podendo acontecer uma sobre dissolução do metal de base para tempos muito prolongados, o que leva a problemas de falta de preenchimento por causa do aumento da viscosidade, gerando diminuição na fluidez do metal de adição fundido, promovendo a formação de defeitos na junta brasada, sendo a formação de poros um dos problemas mais comuns [62].

$\mathrm{Na}$ brasagem de aços inoxidáveis com adição de ligas à base de níquel é um aspecto importante o pré-estabelecimento do tempo de brasagem, já que as altas temperaturas atingidas durante a brasagem facilitam a dissolução do metal de base [62-63].

Adicionalmente, assim como a temperatura, o tempo possui grande influência no tamanho da zona de interface da brasagem. Quanto mais tempo se permanece na temperatura de brasagem, a formação de precipitados ganha maior profundidade e, portanto, a espessura da interface aumenta [64-65].

\subsubsection{Efeito da folga da junta}

É a partir de certo tamanho de folga que a microestrutura da junta brasada pode apresentar a formação de fases frágeis que comumente são desenvolvidas na linha central da junta [66-67]. No entanto, o efeito da folga da junta na microestrutura não é um fator que se possa analisar isoladamente, precisa-se mencionar que os outros fatores atuam simultaneamente.

No caso da brasagem em alta temperatura com ligas a base níquel, é a microsegregação dos elementos depressores da temperatura "liquidus" em direção ao centro da junta, pela primeira fase a nuclear, a qual possui baixa solubilidade destes elementos, que define a formação de fases intermetálicas frágeis. 


\subsubsection{Desenvolvimento microestrutural}

Durante o processo de brasagem, uma vez que o metal de adição fundido preencheu a junta, todo o sistema é imediatamente resfriado até a temperatura ambiente, acarretando na formação de fases intermetálicas frágeis ou unicamente a formação de uma solução sólida continua ao longo da junta (no caso da folga ideal). Para diminuir a presença de fases frágeis e aumentar a formação da solução sólida, o sistema tem que ser mantido em alta temperatura por tempo suficiente, de forma que, promova a interdifusão dos elementos depressores, através de um tratamento térmico de solubilização na junta brasada, posterior a brasagem [60, 68]. Este tratamento térmico de solubilização não é recomendado para os aços duplex devido a probabilidade de precipitar fase sigma durante este tratamento térmico. O estágio inicial no desenvolvimento da microestrutura da junta brasada está relacionado à solidificação isotérmica e o tempo de permanência nesta etapa. O tamanho da folga da junta definirá o tempo de permanência nesta etapa, podendo variar de minutos para folgas pequenas até horas para folgas grandes. Uma descrição deste fenômeno pode ser obtida nas referências [55, 60, 68]:

Considera-se o metal base com composição (D) que será brasado por um metal de adição com composição eutética $(\mathrm{A})$ a uma temperatura de brasagem Ts, conforme mostra a figura 2.15. O metal de adição fundido em contato com o metal base promove a dissolução parcial do mesmo, mudando tanto a composição do metal líquido para $(B)$ como a composição da interface para $(C)$, que iniciará a nucleação de uma solução sólida estável, com composição $(X)$, em vários pontos da interface. Subsequentemente, uma rápida dissolução e precipitação prosseguem no processo até o desparecimento de regiões em contato com o metal de base gerando uma camada continua de solução sólida em equilíbrio com o líquido com composição (B), durante esta etapa o crescimento da solução sólida é rápida. Depois de um tempo de permanência na temperatura Ts o crescimento da solução sólida é controlado por difusão no estado solido dos componentes do metal de adição, assim como dos do metal base, sendo considerado um crescimento lento. A partir da formação de fase contínua na interface ocorre a interdifusão de componentes de elementos de liga depressores da temperatura líquidus $\left(\mathrm{J}_{\mathrm{Dp}}\right)$ do metal de adição para o metal base, 
através da camada de solução sólida formada, e de elementos de liga do metal base para o líquido $\left(\mathrm{J}_{\mathrm{el}}\right)$.
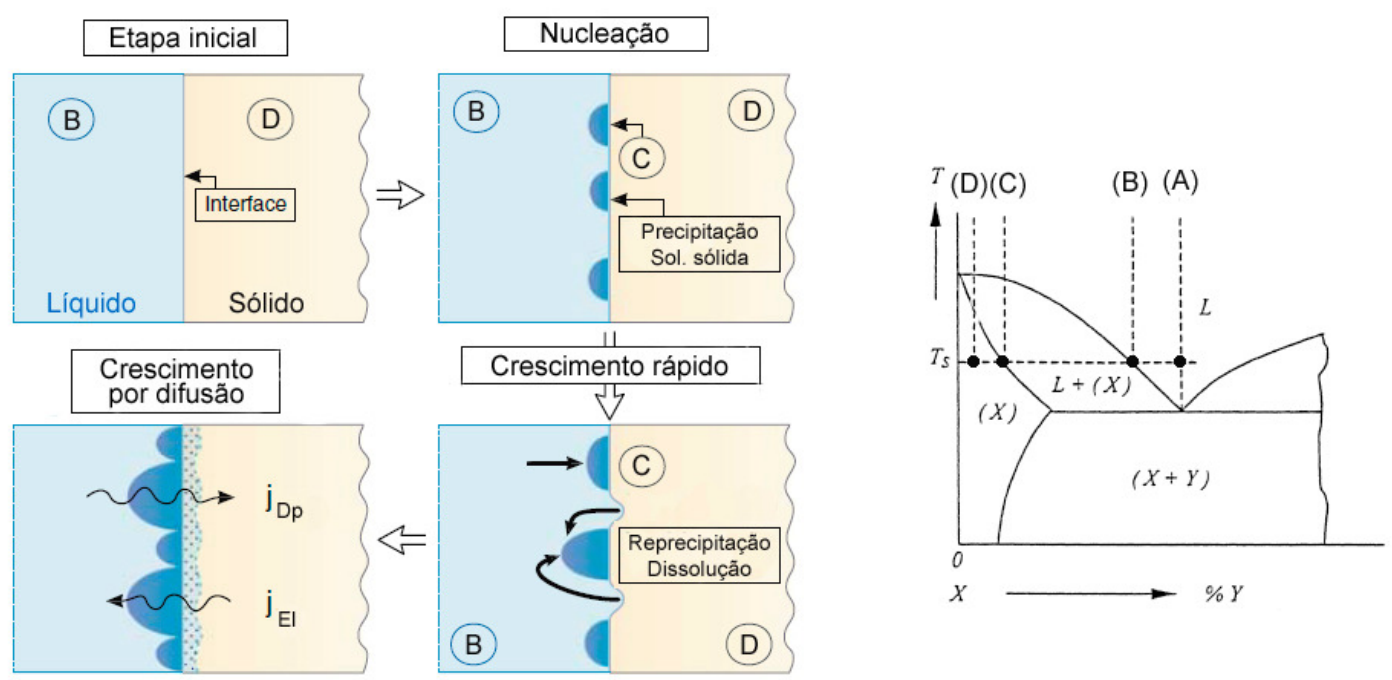

Figura 2.16 - Sequência de desenvolvimento da microestrutura na junta durante a brasagem $[55,60]$.

\subsubsection{Brasabilidade}

Considera-se brasabilidade como 'a capacidade de brasar uma junta de tal maneira que se obtenha o desempenho previsto em um projeto bem executado'[69].

A brasabilidade é uma propriedade que engloba os diferentes aspectos de interação entre os parâmetros de brasagem (folga, temperatura, tempo, atmosfera e ciclos térmicos) com a natureza do metal base e do metal de adição. O resultado da adequada relação entre estes fatores garante o total preenchimento da junta pelo metal de adição, com o mínimo de alteração na microestrutura do metal base, além de se obter uma junta isenta de fases intermetálicas continuas, desde que se utilize a folga ideal. A figura 2.16 apresenta este conceito, esquematicamente. 


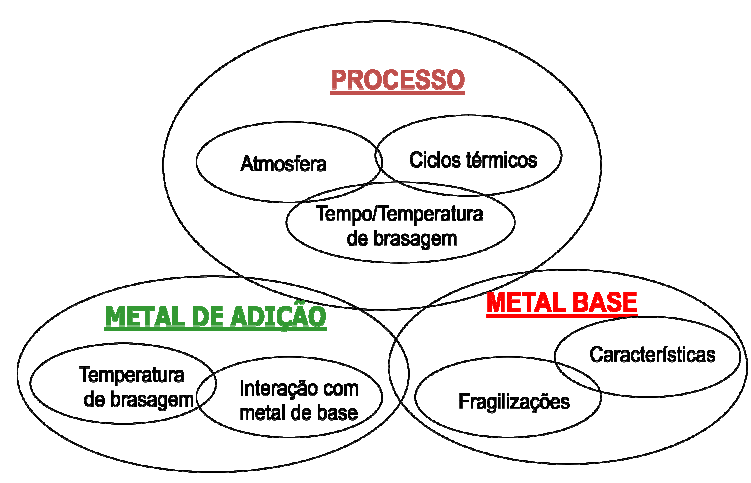

Figura 2.17 - Relação entre os diferentes fatores que definem a brasabilidade [69].

Considera-se que uma junta brasada atingiu o pico da sua brasabilidade quando a relação de resistência mecânica e folga apresenta um valor máximo, como observado na figura 2.17. Nesta figura nota-se a existência de três regiões, duas fora da região de folga ideal (região 1 e 3) e uma com o máximo de resistência mecânica (região 2), que define o intervalo de folga ideal para a brasagem. Na região 1 da figura a queda de resistência mecânica está ligada com defeitos gerados na junta, principalmente pela falta de preenchimento da junta pelo metal de adição líquido. Por outro lado, na região 3 a queda de resistência está associada ao aumento da folga, sendo o fator principal a formação de fases intermetálicas frágeis continuas, como apresentado na figura.

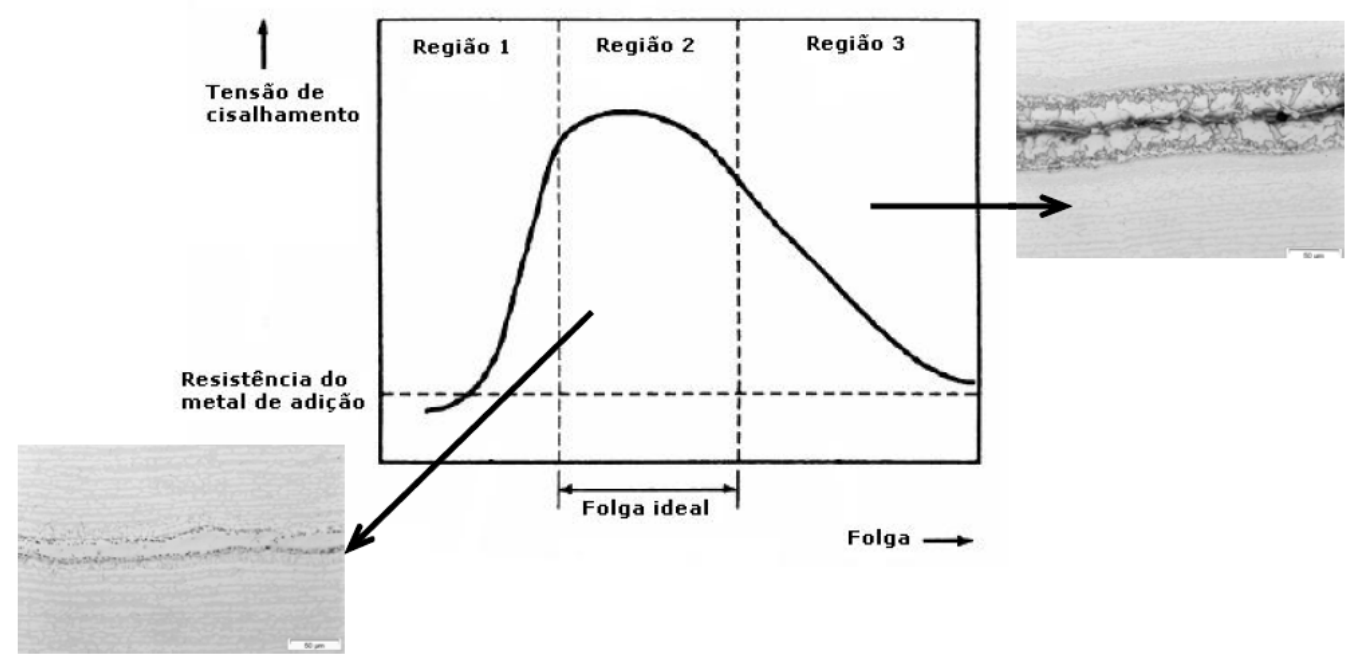

Figura 2.18 - relação entre a folga da junta e resistência mecânica segundo o estado ideal e fora do ideal [66].

A brasabilidade pode ser estudada mediante diversos ensaios que foram desenvolvidos para simular as diversas condições de projeto e de trabalho. Assim, 
os parâmetros para garantir uma junção que otimize as propriedades da junta brasada. Os ensaios de brasabilidade importantes são: ensaio da gota séssil, ensaio de ascensão capilar e ensaio da cunha e suas variantes. Estes ensaios têm como foco principal avaliar a interação do metal de adição líquido sobre o metal base. 


\section{OBJETIVOS}

Os principais objetivos deste trabalho são:

- Estudar a brasabilidade dos aços inoxidáveis duplex UNS S32101, UNS S32304, UNS S32507 e UNS S32707, através da folga ideal, em forno contínuo com atmosfera de hidrogênio utilizando como metal de adição ligas à base de níquel.

- Caracterizar metalograficamente a junta brasada nos diferentes aços inoxidáveis duplex e parâmetros de brasagem (tempo de brasagem e folga da junta). 


\section{MATERIAIS E MÉTODOS}

\subsection{Metal base}

Foram utilizados como material de base quatro tipos diferentes de aços inoxidáveis duplex:

- Aço inoxidável duplex de baixa liga (duplex "lean") UNS S32101

- Aço inoxidável duplex de baixa liga (duplex “lean") UNS S32304

- Aço inoxidável duplex de alta liga (superduplex) UNS S32750

- Aço inoxidável duplex de alta liga (hiperduplex) UNS S32707

A composição química dos diferentes aços está listada na tabela 4.1.

Tabela 4.1 - Composição química dos diferentes aços inoxidáveis duplex utilizados.

\begin{tabular}{|c|c|c|c|c|c|c|c|c|c|c|}
\hline $\begin{array}{c}\text { Designação } \\
\text { UNS }\end{array}$ & \multicolumn{10}{|c|}{ Composição Química (\% em peso) } \\
\cline { 2 - 12 } & $\mathbf{N}$ & $\mathrm{C}$ & $\mathrm{Si}$ & $\mathrm{Mn}$ & $\mathrm{P}$ & $\mathrm{Cu}$ & $\mathrm{Ti}$ & $\mathbf{N i}$ & $\mathbf{C r}$ & $\mathbf{M o}$ \\
\hline S32101 & $\mathbf{0 , 2 2}$ & 0,023 & 0,64 & 4,98 & 0,025 & 0,16 & - & $\mathbf{1 , 6 4}$ & $\mathbf{2 1 , 5 1}$ & $\mathbf{0 , 2}$ \\
\hline S32304 & $\mathbf{0 , 1 2 5}$ & 0,019 & 0,39 & 1,48 & 0,028 & 0,22 & 0,006 & $\mathbf{4 , 8 4}$ & $\mathbf{2 3 , 3 5}$ & $\mathbf{0 , 3 6}$ \\
\hline S32750 & $\mathbf{0 , 3 0}$ & 0,016 & 0,21 & 0,81 & 0,022 & 0,20 & - & $\mathbf{6 , 8 6}$ & $\mathbf{2 5 , 0 8}$ & $\mathbf{3 , 8 2}$ \\
\hline S32707 & $\mathbf{0 , 4 3 8}$ & 0,017 & 0,28 & 0,95 & 0,020 & 0,146 & 0,006 & $\mathbf{6 , 0 1}$ & $\mathbf{2 6 , 5 6}$ & $\mathbf{4 , 3 7}$ \\
\hline
\end{tabular}

Os aços UNS S32101, UNS S32304, UNS S32750 foram fornecidos na forma de chapas com espessuras de $3 \mathrm{~mm}, 3 \mathrm{~mm}$ e $6 \mathrm{~mm}$ respectivamente. Já o aço hiperduplex UNS S32707 estudado foi adquirido no formato de tubo com $20 \mathrm{~mm}$ de diâmetro e 2 mm de espessura. 


\subsection{Metal de adição}

No presente trabalho foi utilizada a liga BNi-7 como metal de adição, por se tratar de uma liga de alta temperatura, de características adequadas para a brasagem de aços inoxidáveis, além de ser amplamente utilizada na literatura. A composição química da liga apresenta-se na tabela 4.3.

Tabela 4.2 - Composição química do metal de adição.

\begin{tabular}{|c|c|c|c|c|c|c|c|c|c|c|c|}
\hline $\begin{array}{c}\text { Designação } \\
\text { AWS }\end{array}$ & \multicolumn{10}{|c|}{ Composição Química (\% em peso) } \\
\cline { 2 - 12 } & $\mathrm{Fe}$ & $\mathrm{C}$ & $\mathrm{Si}$ & $\mathrm{Mn}$ & $\mathbf{P}$ & $\mathrm{S}$ & $\mathrm{Ti}$ & $\mathbf{N i}$ & $\mathbf{C r}$ & $\mathrm{B}$ & $\mathrm{Al}$ \\
\hline BNi-7 & 0,05 & 0,014 & 0,05 & $<0,001$ & 10,14 & 0,008 & $<0,001$ & $\mathrm{Bal}$. & 13,76 & 0,01 & $<0,001$ \\
\hline
\end{tabular}

Pertencente ao sistema Ni-Cr-P, a liga BNi-7 é empregada para a brasagem de estruturas de trocadores de calor, montagem de tubos de paredes finas e outras estruturas que sejam utilizadas em temperaturas elevadas. É recomendada para aplicações nucleares e componentes de paredes finas, onde ligas com presença de boro como elemento nas adições de brasagem não é recomendável pela alta erosividade deste elemento.

\subsection{Equipamento para brasagem}

A brasagem dos corpos de prova foi realizada em um forno continuo de esteira, aquecido eletricamente e utilizando uma atmosfera de hidrogênio e nitrogênio. $A$ configuração do forno está formada basicamente por cinco zonas de aquecimento, seguida de uma zona de resfriamento. As peças a serem brasadas são conduzidas atraves das zonas por meio de uma esteira transportadora. 


\subsection{Parâmetros de brasagem}

\subsubsection{Temperatura}

Como foi discutido anteriormente, a temperatura de brasagem determinará o total ou parcial preenchimento da folga, além das diferentes interações e reações entre o metal de base e o metal de adição, pois sua influência está relacionada com a fusão do metal de adição, ao molhamento e espalhamento do mesmo, à difusão de elementos entre o metal de adição e metal de base (e vice-versa) e a microestrutura resultante da junta durante o ciclo de brasagem.

A distribuição de temperatura dentro do forno esta dividida em três zonas que determinaram o pré-aquecimento e temperatura de brasagem. A leitura da temperatura nas diferentes zonas é feitas por termopares e mostrada no display do equipamento, como está apresentado na figura 4.1.

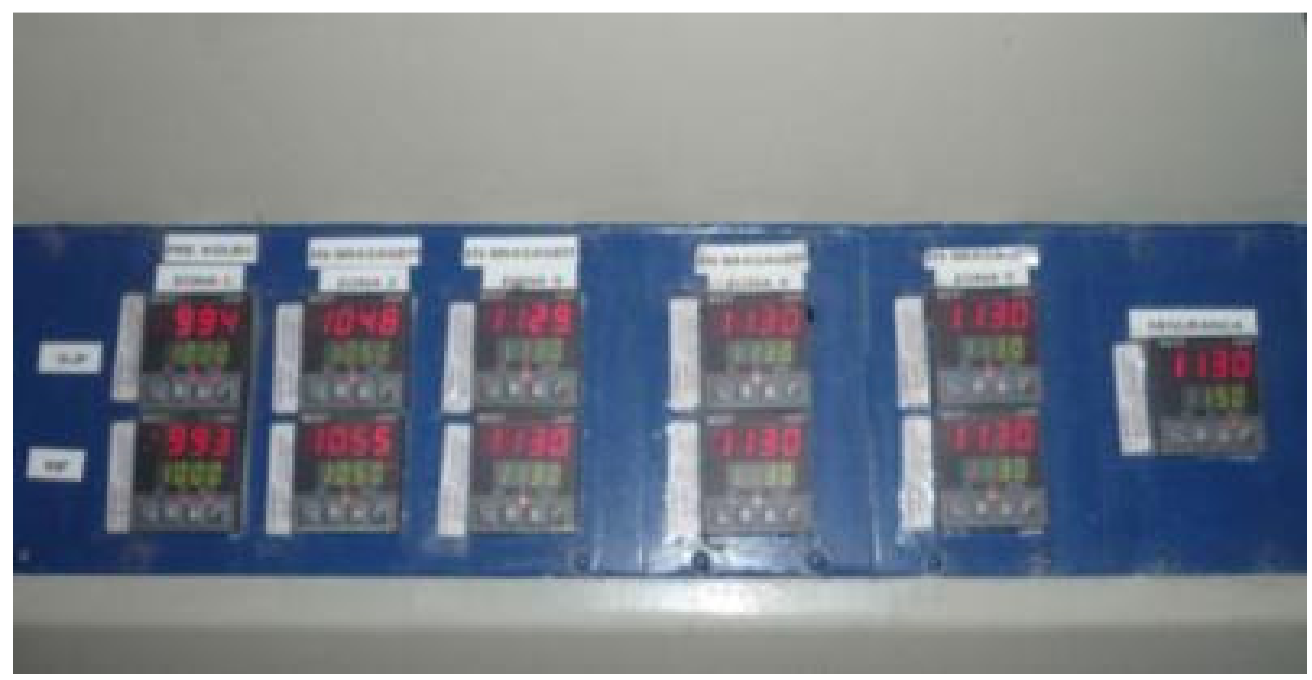

Figura 4.1 - Detalhe do painel de controle do forno durante a brasagem.

As temperaturas das diferentes zonas de aquecimento durante a brasagem das amostras deste trabalho apresentam-se na tabela 4.3. 
Tabela 4.3 - Distribuição de temperatura no forno durante o ciclo de brasagem.

\begin{tabular}{|c|c|c|c|c|c|}
\cline { 2 - 6 } \multicolumn{1}{c|}{} & $\begin{array}{c}\text { Zona 1 } \\
\text { (Pré- } \\
\text { aquecimento) }\end{array}$ & $\begin{array}{c}\text { Zona 2 } \\
\text { (Pré- } \\
\text { aquecimento) }\end{array}$ & $\begin{array}{c}\text { Zona 3 } \\
\text { (Zona de } \\
\text { brasagem) }\end{array}$ & $\begin{array}{c}\text { Zona 4 } \\
\text { (Zona de } \\
\text { brasagem) }\end{array}$ & $\begin{array}{c}\text { Zona 5 } \\
\text { (Zona de } \\
\text { brasagem) }\end{array}$ \\
\hline $\begin{array}{c}\text { Temperatura } \\
\left({ }^{\circ} \mathrm{C}\right)\end{array}$ & 993 & 1050 & 1130 & 1130 & 1130 \\
\hline
\end{tabular}

\subsubsection{Velocidade de esteira}

Através do controle da velocidade de esteira que se determina o tempo de permanência das amostras na temperatura de brasagem em equipamentos como os fornos contínuos.

As velocidades de esteira selecionadas para este trabalho foram duas: 80 e 200 $\mathrm{mm} / \mathrm{min}$. Considerando que o comprimento da zona de brasagem do forno é de $2520 \mathrm{~mm}$, o tempo de brasagem equivalente para estas duas velocidades é de aproximadamente 32 e 12 min respectivamente.

\subsubsection{Condições de processo}

Definiram-se como principais variáveis do processo a temperatura, folga da junta e o tempo. A combinação destas variáveis gerou uma serie de condições de processo, sendo a temperatura a variável que permaneceu constante nos ensaios. Porém, as condições do processo ficaram em função da folga da junta e do tempo de brasagem, tais condições são esquematizadas na figura 4.2. 


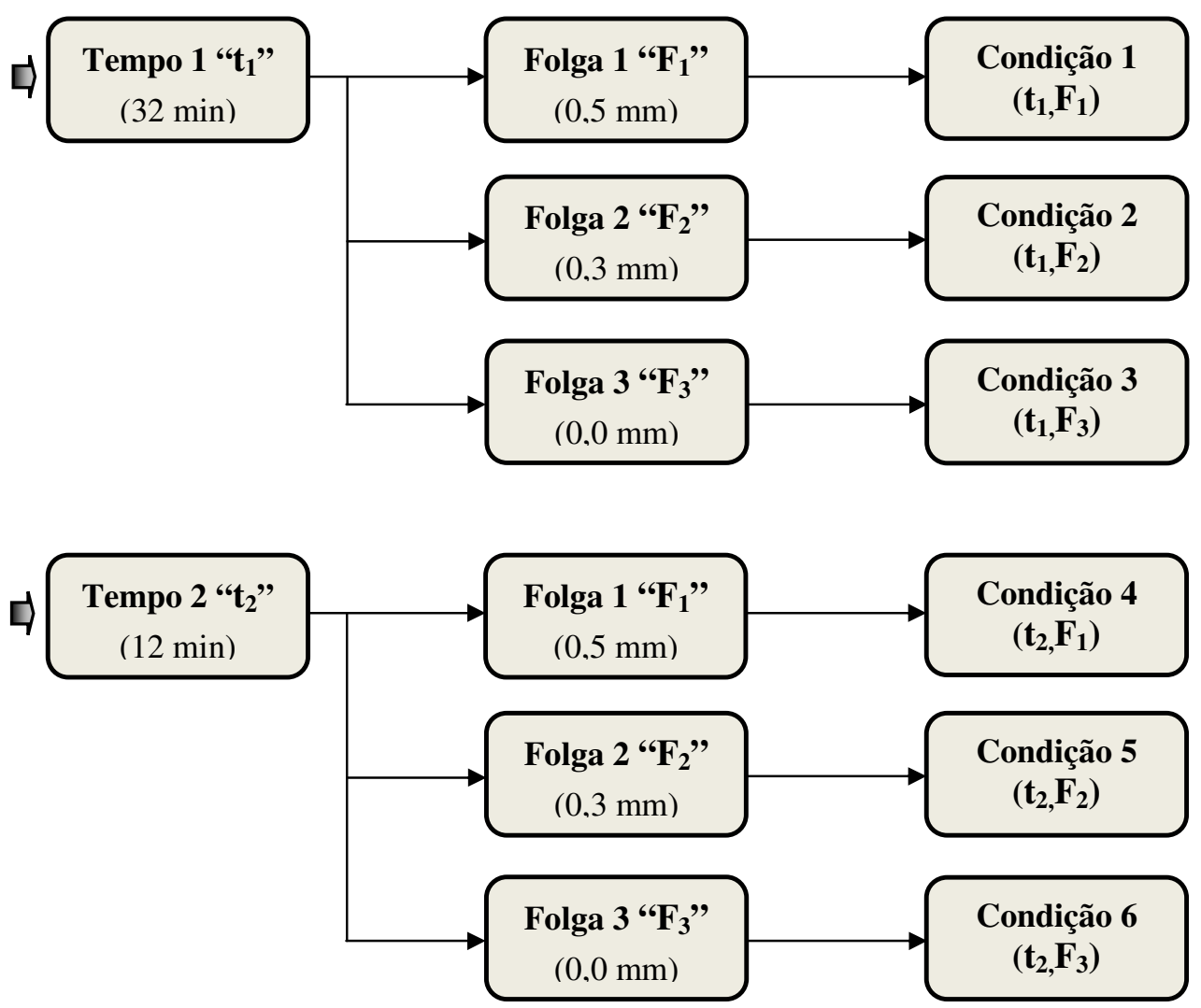

Figura 4.2 - Esquema de desenvolvimento das condições de brasagem.

\subsection{Metodologia}

\subsubsection{Preparação dos corpos de prova}

O formato da junta foi projetado antes do processo de brasagem, visando conseguir uma adequada união dos diferentes aços usados e posteriormente facilitar a análise da mesma. Achou-se por conveniente adotar o formato utilizado no ensaio da cunha, onde foram cortadas pequenas chapas com dimensões de 20x25 mm e 20x20 mm para cada tipo de aço inoxidável duplex, com exceção do aço UNS S32707, que foi cortado em pequenos anéis de $8 \mathrm{~mm}$ de comprimento dada a sua forma tubular. A figura 4.3 ilustra, a disposição dos corpos de prova após sua montagem. 


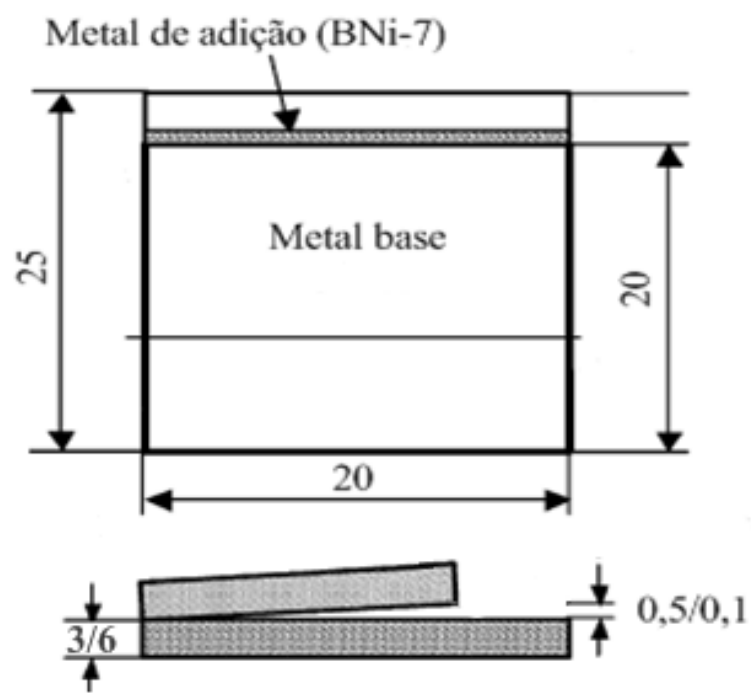

Figura 4.3 - Esquema da montagem dos corpos de prova.

Após o processo de brasagem os corpos de prova foram cortados longitudinalmente (figura 4.4), procurando uma melhor visualização e, portanto, uma adequada análise da junta brasada. O corte foi feito no equipamento "ISOMET" com um disco diamantado, considerando os parâmetros estabelecidos para o corte de aços inoxidáveis.
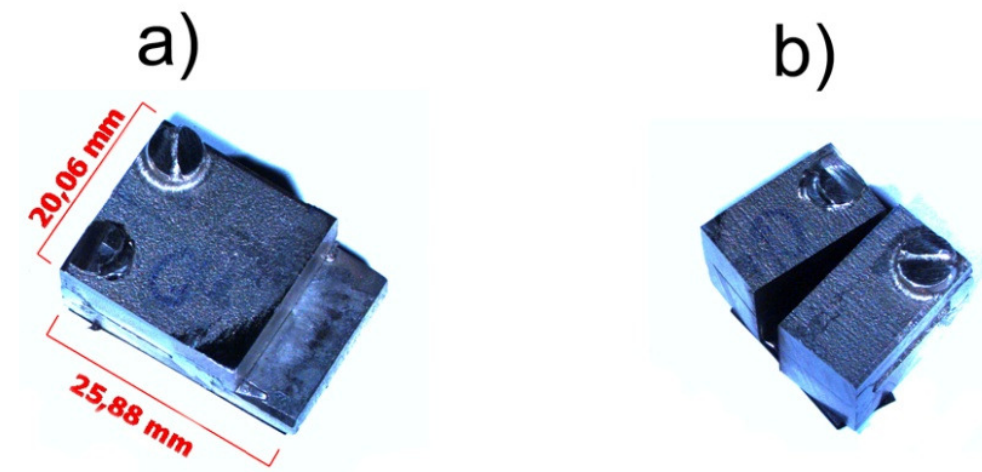

c)

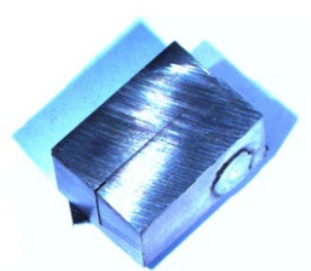

Figura 4.4 - Vistas isométricas do corpo de prova , a) montado b) cortado c) seção de análise. 


\subsection{Caracterização microestrutural}

A caracterização microestrutural foi realizada nos materiais nos estados comorecebido e brasados. Na continuação são descritas as diversas técnicas utilizadas.

\subsubsection{Microscopia óptica}

Iniciou-se a preparação dos corpos de prova com o embutimento a quente em baquelite. Em seguida foram lixados em uma sequência com granulometrias: 180, 220, 320, 400, 600 e 1000 meshes e polidas com pasta de diamante na sequência: 6 , 3 e $1 \mu \mathrm{m}$ de tamanho médio de partícula. Posteriormente, foi realizado um polimento automático usando uma suspensão de sílica coloidal, com tamanho médio de partícula de 0,06 $\mu \mathrm{m}$.

Uma vez obtida a superfície totalmente polida, o material foi submetido a duplo ataque eletrolítico visando obter diferenciação entre a microestrutura da região brasada e a microestrutura do metal de base. Os ataques utilizados foram: Hidróxido de sódio $20 \%(\mathrm{NaOH})$, com tempo aproximado de 120 segundos e ácido crômico $10 \%$ durante 45 segundos, ambos com tensão de 3V. O equipamento utilizado para 0 ataque foi o POLECTROL da struers.

A aquisição de imagens foi feita utilizando a câmera digital Opticam OPT 10000 acoplada no microscópio de marca Olympus BX60M. Foram analisadas as regiões com folgas de $0,0.3$ e $0.5 \mathrm{~mm}$ dos corpos de prova do ensaio de soldabilidade da cunha. Foram também medidas as folgas ideais para cada um dos corpos de prova estudados. A folga ideal é medida quando a junta possui somente a fase $\gamma$-Ni e, se houver a presença de intermetálicos no centro da junta, que ele seja descontinuo e em pequena quantidade. 


\subsubsection{Microscopia eletrônica}

As amostras foram submetidas à análise por microscopia eletrônica de varredura (MEV) após o polimento. Para observação das microestruturas foram utilizadas imagens de elétrons retroespalhados (BSE). Por meio desta técnica é possível identificar e obter informações das fases em relação a sua diferença de contraste. Esta diferença de contraste vem em função do numero atômico dos elementos presentes nas diversas fases. Para análise química dos elementos metálicos das fases foi utilizada a análise por dispersão de energia (EDS), acoplada ao MEV. Utilizou-se o MEV de marca Philips, modelo XL-30, instalado no PMT/USP.

\subsubsection{Difração de raios $X$}

Utilizou-se a análise por difração de raios-X para caracterizar as fases presentes na região da junta brasada dos diferentes AID. Os corpos de prova foram preparados de tal forma que a região de análise foi levada até o polimento final. O equipamento utilizado foi um difratômetro marca PHILIPS X'PERT do Laboratório de Caracterização Tecnológica (LCT) do Departamento de Engenharia de Minas e Petróleo da Escola Politécnica da USP (PMI/EPUSP), operando com radiação de cobre (CuK $\alpha, \lambda=1,542 \AA$ ), com corrente de $40 \mathrm{~mA}$, tensão aplicada de $40 \mathrm{kV}$ e passo de varredura angular de $0,02 \%$, compreendendo uma faixa de ângulo de varredura $(2 \theta)$ entre 20 e $110^{\circ}$.

A análise prévia dos resultados foi realizada utilizando-se as fichas JCDPS com suporte do programa X'Pert High Score Plus. 


\section{RESULTADOS}

\subsection{Análise Microestrutural}

\subsubsection{Microscopia Óptica}

Nesta seção serão apresentados os resultados relacionados com a microestrutura do material brasado nas diferentes condições de processamento após os ataques eletroquímicos realizados nos diferentes AID

\subsubsection{Material como recebido}

A figura 5.1 apresenta as micrografias dos diferentes AID's utilizados neste trabalho. O material foi fornecido pelo fabricante no estado solubilizado. Mostram-se em detalhe as três direções da chapa, ressaltando a direção de laminação, verificandose nitidamente a estrutura lamelar alternada dos grãos de ferrita e austenita. Em todos os casos, a fase escura corresponde à ferrita e a fase clara à austenita, constatando-se desta forma a distribuição das ilhas de austenita na matriz ferrítica, tal como mencionado anteriormente na revisão da literatura.

Ao observar detidamente as micrografias, pode-se notar uma pequena diferença no tamanho de grão do AID UNS S32750 quando comparado com os outros aços, esta leve diferença poder-se-ia atribuir a maior espessura da chapa, sendo esta espessura duas vezes maior do que os outros AID's. Outro fato em consideração, é a distribuição desordenada dos grãos na direção transversal no AID UNS S32707, já que, ao se comparar com o formato dos grãos dos outros AID's nesta mesma direção, existe certa falta de uniformidade. 
a)

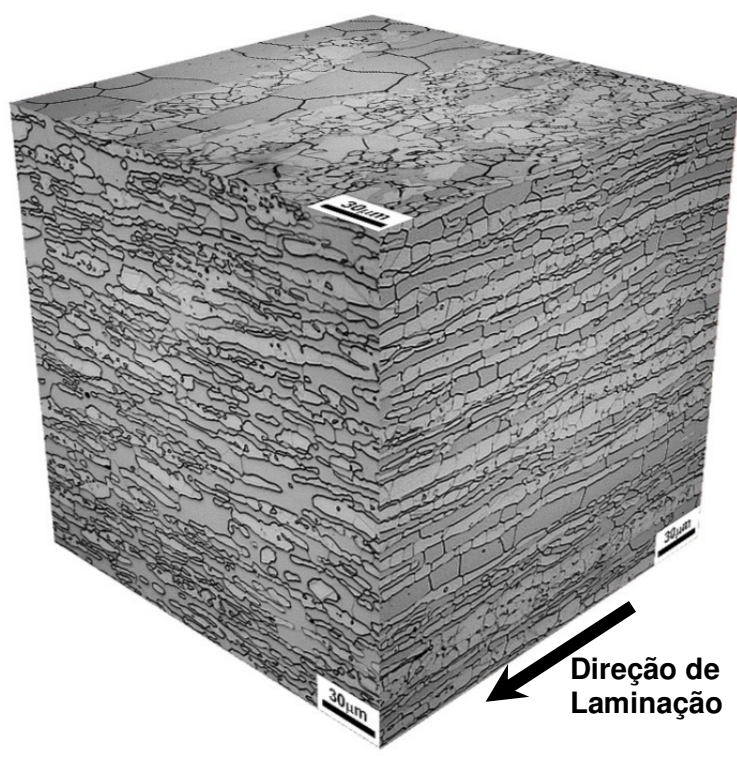

c)

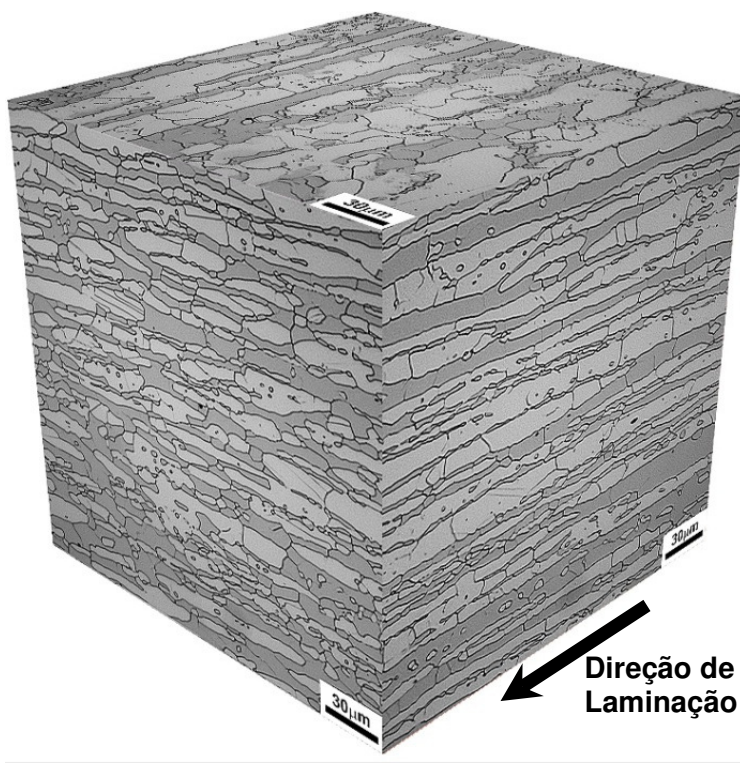

b)

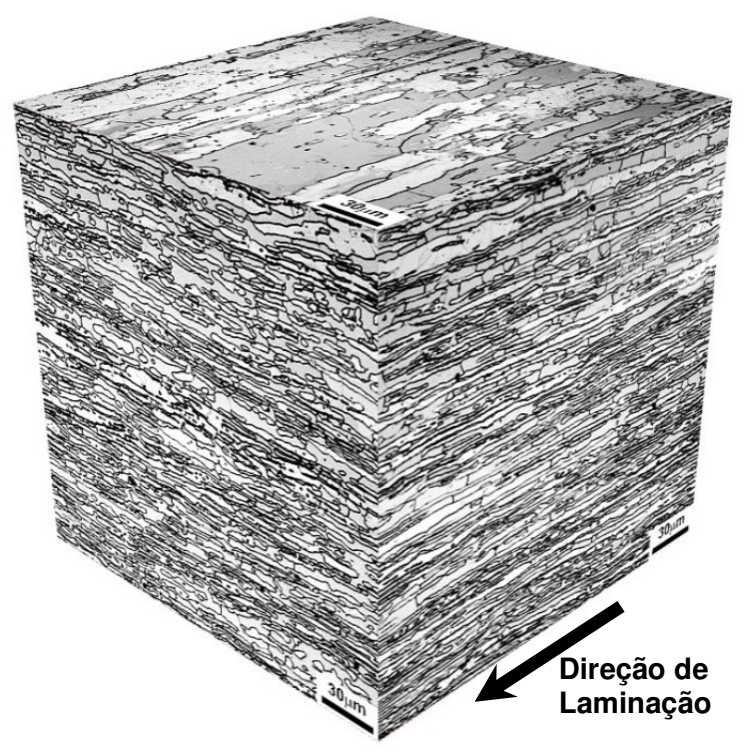

d)

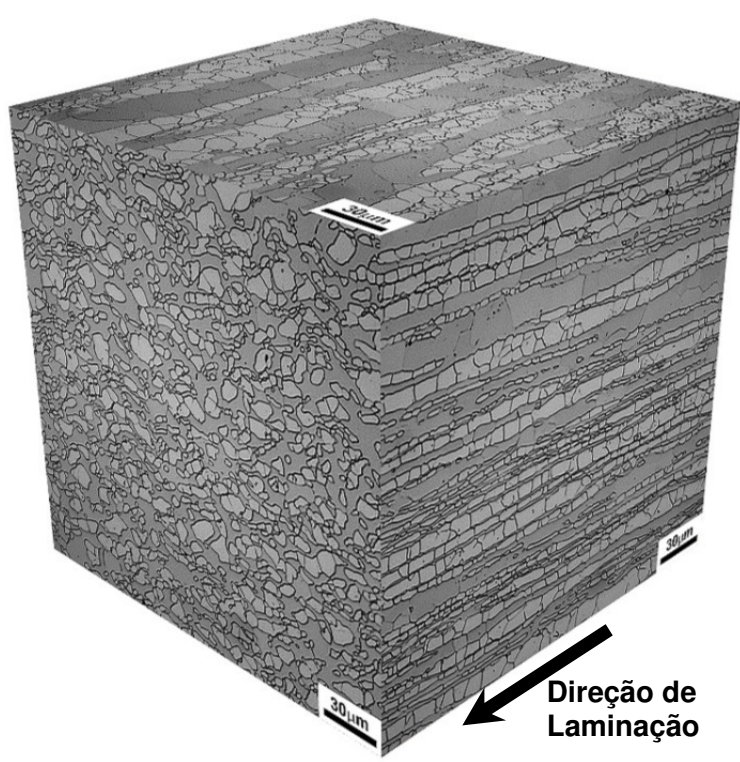

Figura 5.1 - Micrografias 3D dos AID's no estado como-recebido. a) UNS S32101, b) UNS S32304, c) UNS S32750 e d) UNS S32707. 


\subsubsection{Material Brasado}

\section{A. Análise microestrutural condição 1: tempo $32 \mathrm{~min}$ e folga $0,5 \mathrm{~mm}$.}

As figuras 5.2 a 5.5 apresentam a microestrutura da região brasada dos AID's UNS S32101, UNS S32304, UNS S32750 e UNS S32707. Pode-se observar, em todos os casos, a boa molhabilidade entre o metal de adição e o metal de base, já que, a linha de interação entre os mesmos apresenta uma relativa uniformidade e está isenta de grandes defeitos, além de não mostrar uma dissolução do metal de base muito pronunciada. Porém, nota-se uma clara diferença entre a região central e a região da interface na brasagem. A região central apresenta uma microestrutura composta predominantemente por intermetálicos, tal como é mostrada nas figuras 5.2 a 5.5 para todos os casos. Já na região da interface, observa-se uma microestrutura composta essencialmente por uma fase continua de muita similaridade com a austenita dos AID's denominada por diferentes autores como uma solução sólida rica em níquel $\gamma$-Ni [59]. Esta solução sólida além de ter um crescimento a partir da linha de interface também se encontra distribuída por toda a região central da junta brasada, originada por uma reação eutética.

Nota-se que, para os AID's UNS S32101 e UNS S32304 (AIDL) brasados nesta condição, a zona do metal base adjacente à região brasada apresenta a formação de uma camada contínua da fase austenítica, além disso, não se observa a formação de intermetálicos intergranulares nem transgranulares nesta zona. No entanto, uma clara decomposição da microestrutura do metal de base logo em seguida da linha de interface é observada no AID UNS S32750 (figura 5.4) e UNS S32707 (figura 5.5), apresentando-se de forma mais severa neste último. Esta decomposição é dada preferencialmente na fase ferrítica do aço como observado na ampliação das figuras 5.4 e 5.5. Assim, pelas características mostradas, confrontando com a literatura, além da coloração obtida após ataque é possível identificar está fase como a fase sigma. 


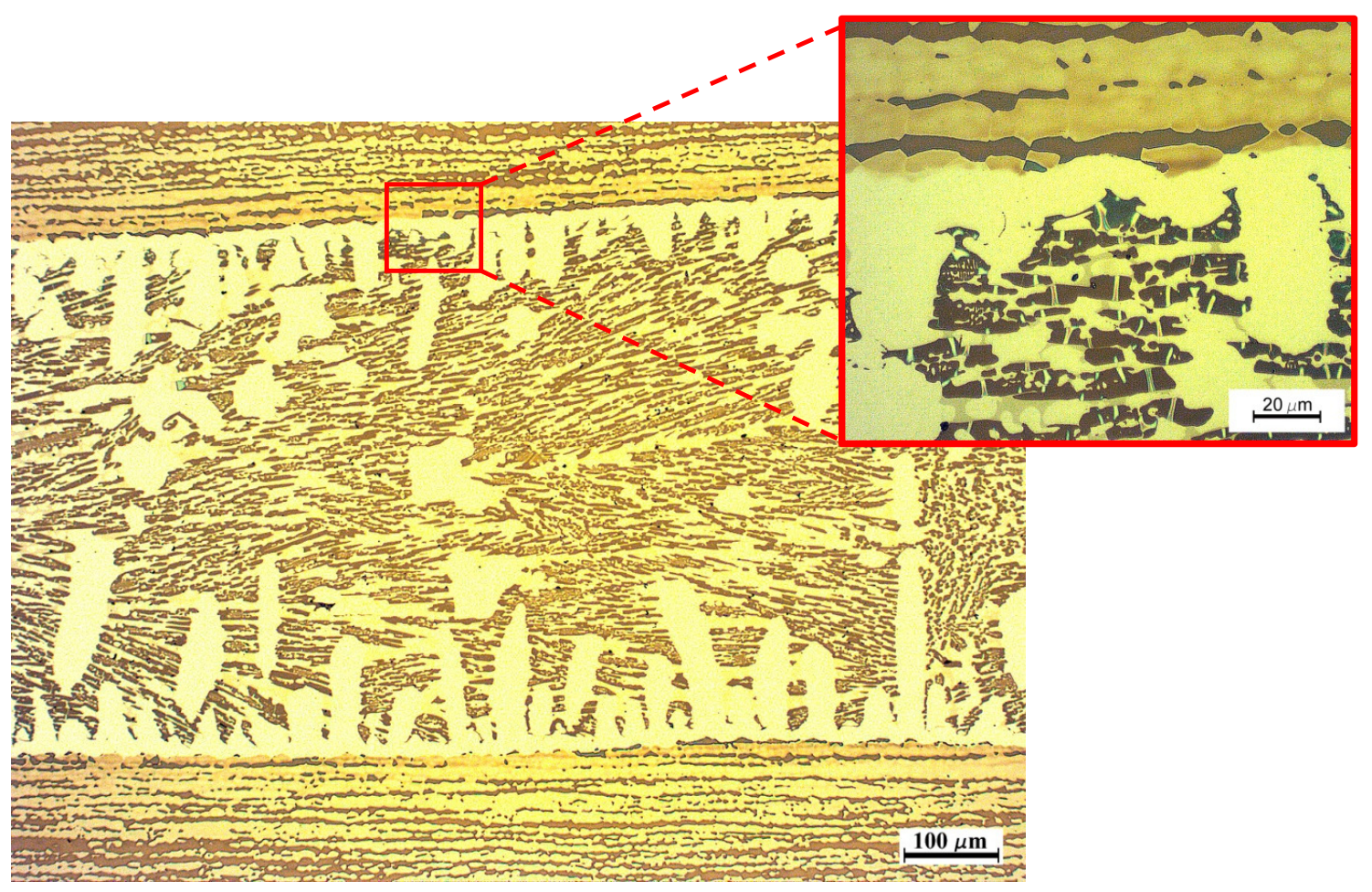

Figura 5.2 - Microestrutura da junta brasada obtida por microscopia óptica do AID. UNS S32101 para um tamanho de folga de $0,5 \mathrm{~mm}$. No detalhe se observa a região da interface da junta.

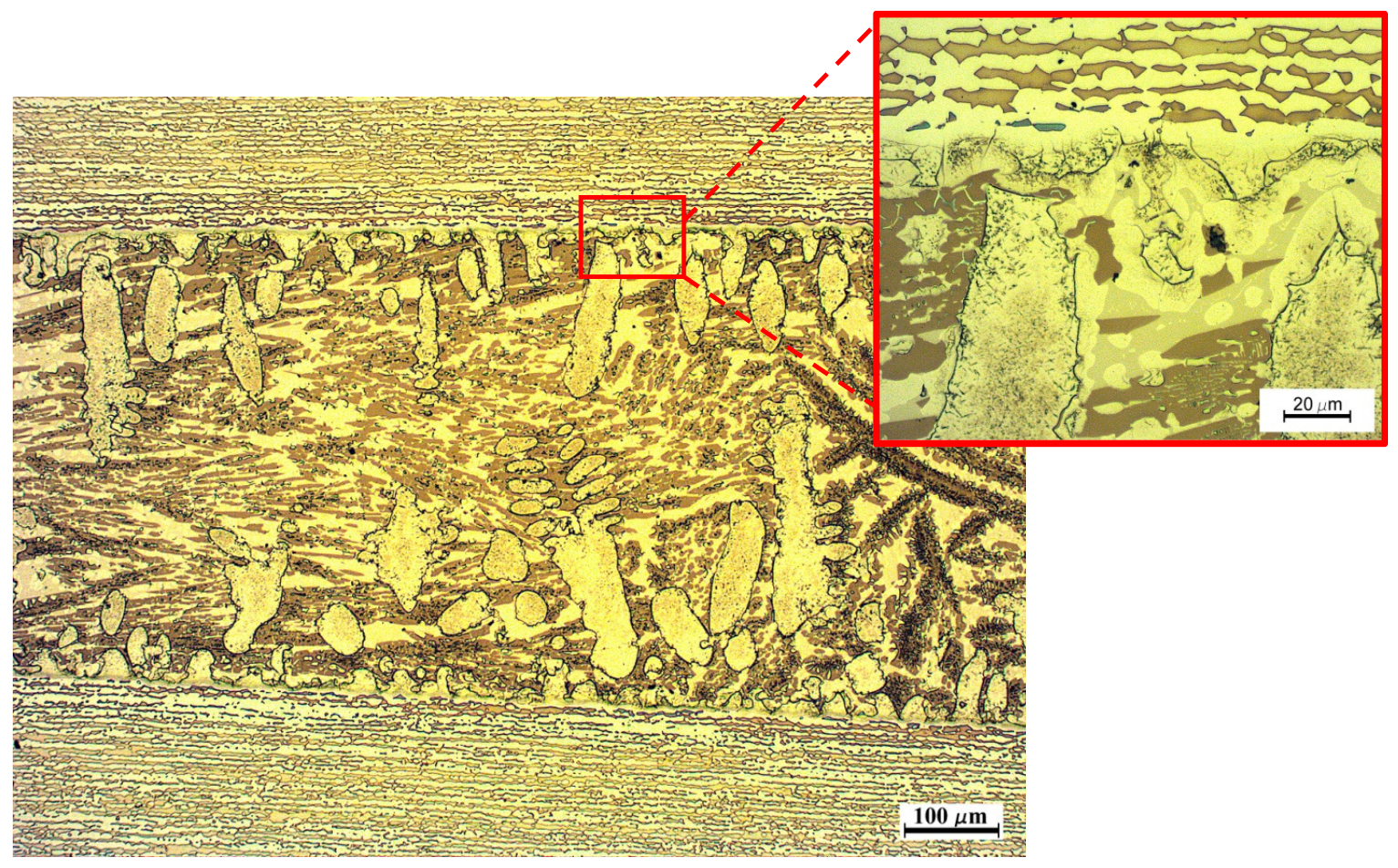

Figura 5.3 - Microestrutura da junta brasada obtida por microscopia óptica do AID. UNS S32304 para um tamanho de folga de $0,5 \mathrm{~mm}$. No detalhe se observa a região da interface da junta. 


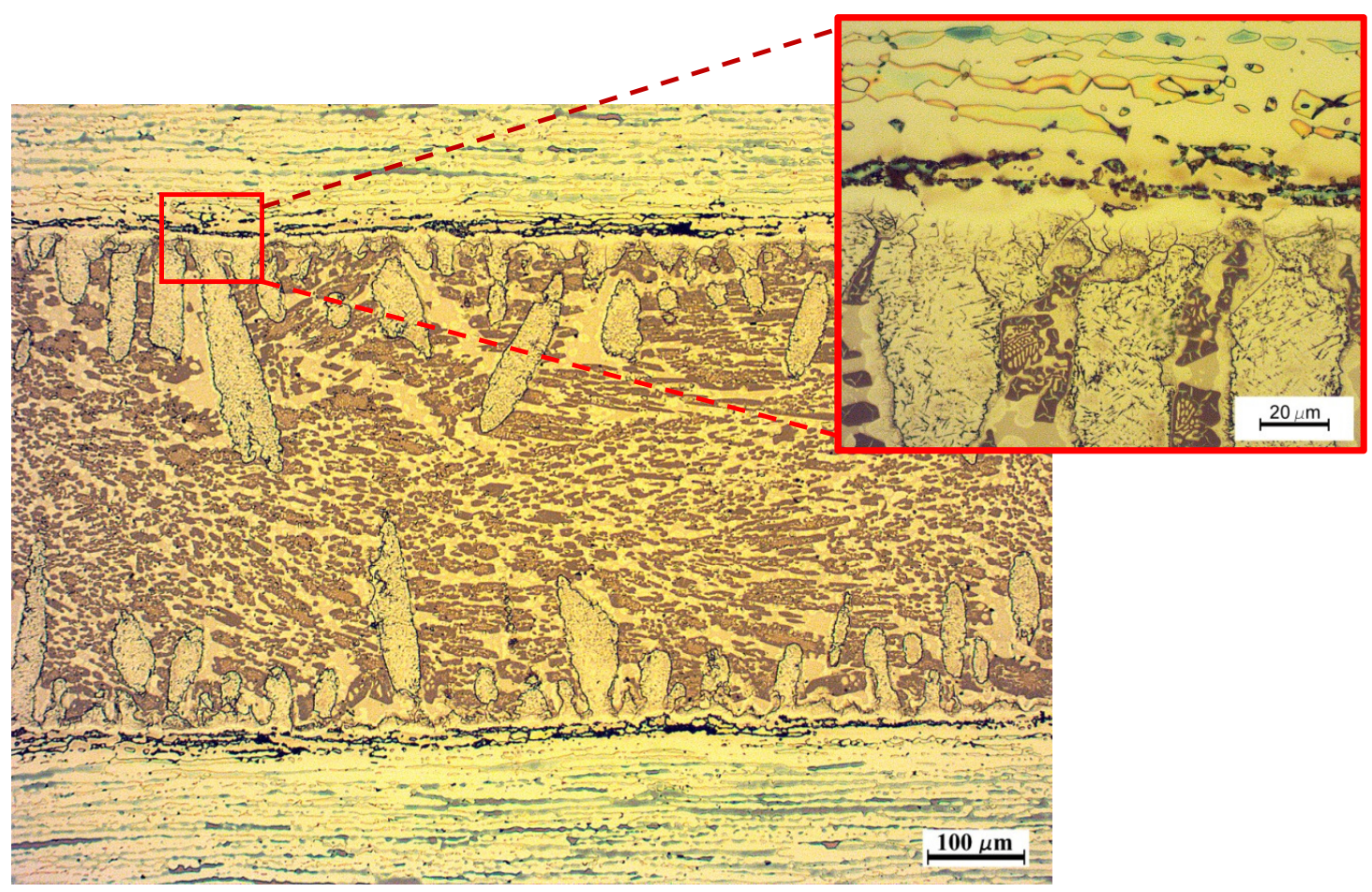

Figura 5.4 - Microestrutura da junta brasada obtida por microscopia óptica do AID. UNS S32750 para um tamanho de folga de $0,5 \mathrm{~mm}$. No detalhe se observa a região da interface da junta.

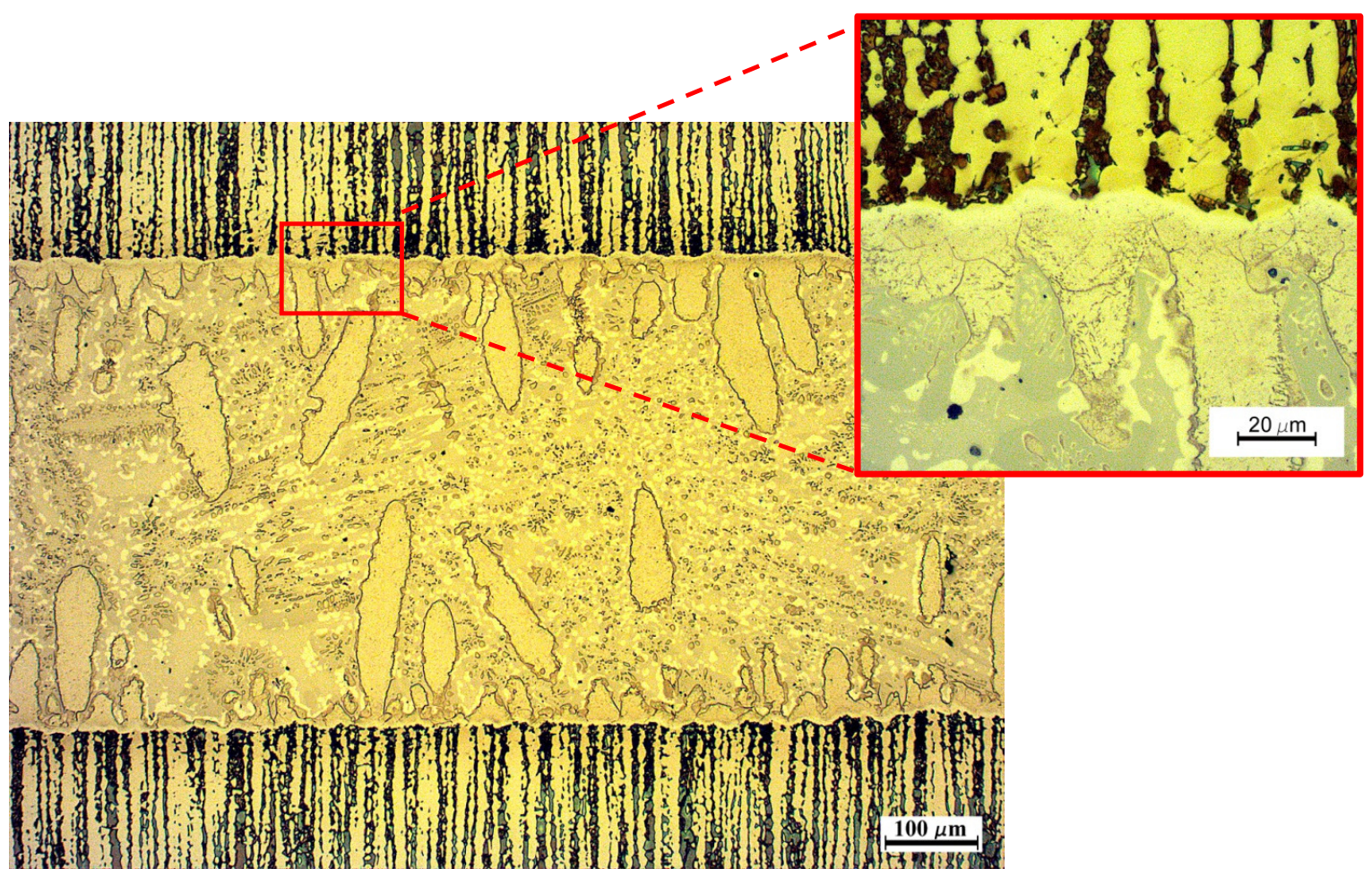

Figura 5.5 - Microestrutura da junta brasada obtida por microscopia óptica do AID. UNS S32707 para um tamanho de folga de $0,5 \mathrm{~mm}$. No detalhe se observa a região da interface da junta. 


\section{B. Análise microestrutural condição 2: tempo $32 \mathrm{~min}$ e folga $0,3 \mathrm{~mm}$}

As figuras 5.6 a 5.9 apresentam a microestrutura da região brasada dos AID's UNS S32101, UNS S32304, UNS S32750 e UNS S32707. A brasagem foi realizada no sentido da laminação para todos os AID's exceto para o aço UNS S32707 (figura 5.9) onde foi orientada no sentido transversal. Nesta condição com a diminuição do tamanho da folga é possível observar de forma geral na microestrutura da junta brasada uma maior formação da solução sólida rica em níquel $(\gamma-\mathrm{Ni})$ para todos os AID's, mostrando-se distribuída tanto na região da interface, como na região central da brasagem. No entanto, o AlHD UNS S32707 (figura 5.9) apresenta uma maior formação da fase continua, quando comparados com a condição 1 no item anterior. Por outro lado, apesar da diminuição do tamanho de folga a linha de interação da junta brasada, para todos os aços, permanece contínua e homogênea sem mostrar zonas de grande diluição.

Conforme mencionado no item anterior (condição 1), verificou-se a formação de uma camada contínua de fase austenítica imediatamente depois da zona da interface, fenômeno que também é possível ser observado para esta condição. Desta forma, o crescimento da solução sólida rica em níquel a partir da interface para o centro da junta pode ser mais bem apreciada nesta condição.

Verifica-se também, assim como na condição anterior, uma forte decomposição da ferrita próxima a região da interface da junta nos AID UNS S32750 (figura 5.8)e UNS S32707 (figura 5.9), corroborando-se uma vez mais que pelas características apresentadas tratar-se-ia da fase sigma, podendo-se distinguir a severidade deste fenômeno estendendo-se em quase todo o material base no AIHD (figura 5.9). Já o AISD (figura 5.8) permanece com uma linha semi continua ao longo da interface da junta. 


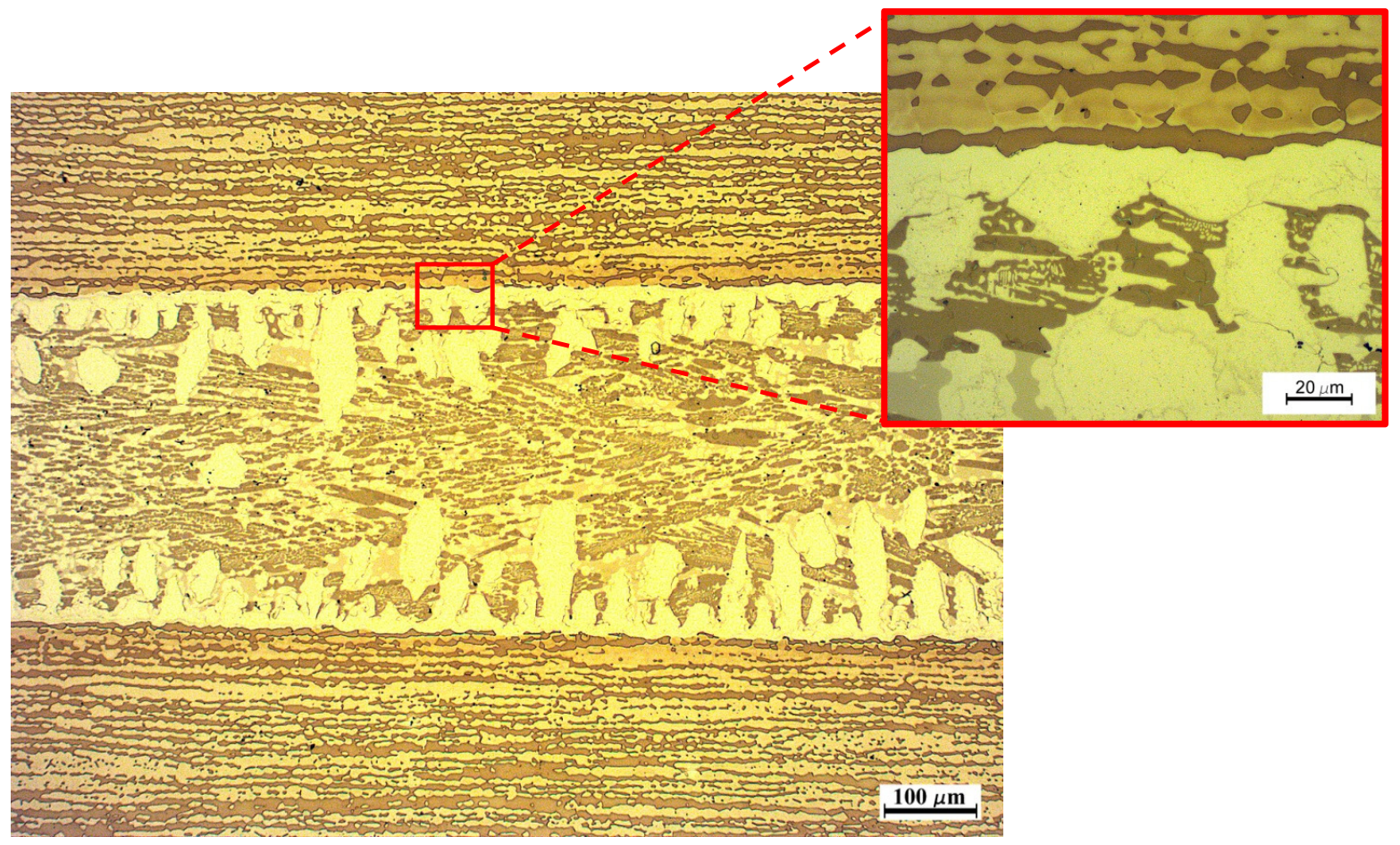

Figura 5.6 - Microestrutura da junta brasada obtida por microscopia óptica do AID. UNS S32101 para um tamanho de folga de $0,3 \mathrm{~mm}$. No detalhe se observa a região da interface da junta.

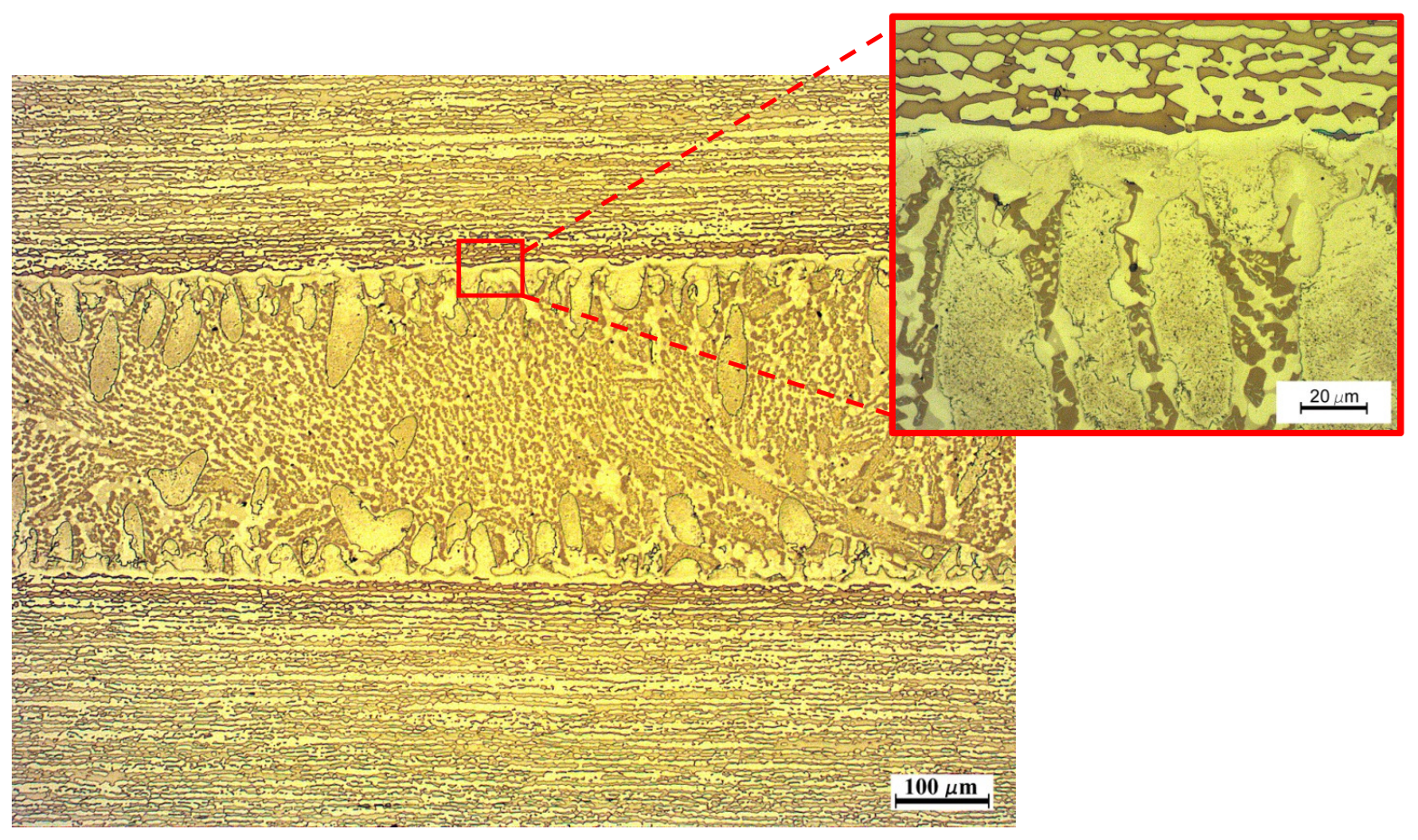

Figura 5.7 - Microestrutura da junta brasada obtida por microscopia óptica do AID. UNS S32304 para um tamanho de folga de $0,3 \mathrm{~mm}$. No detalhe se observa a região da interface da junta. 


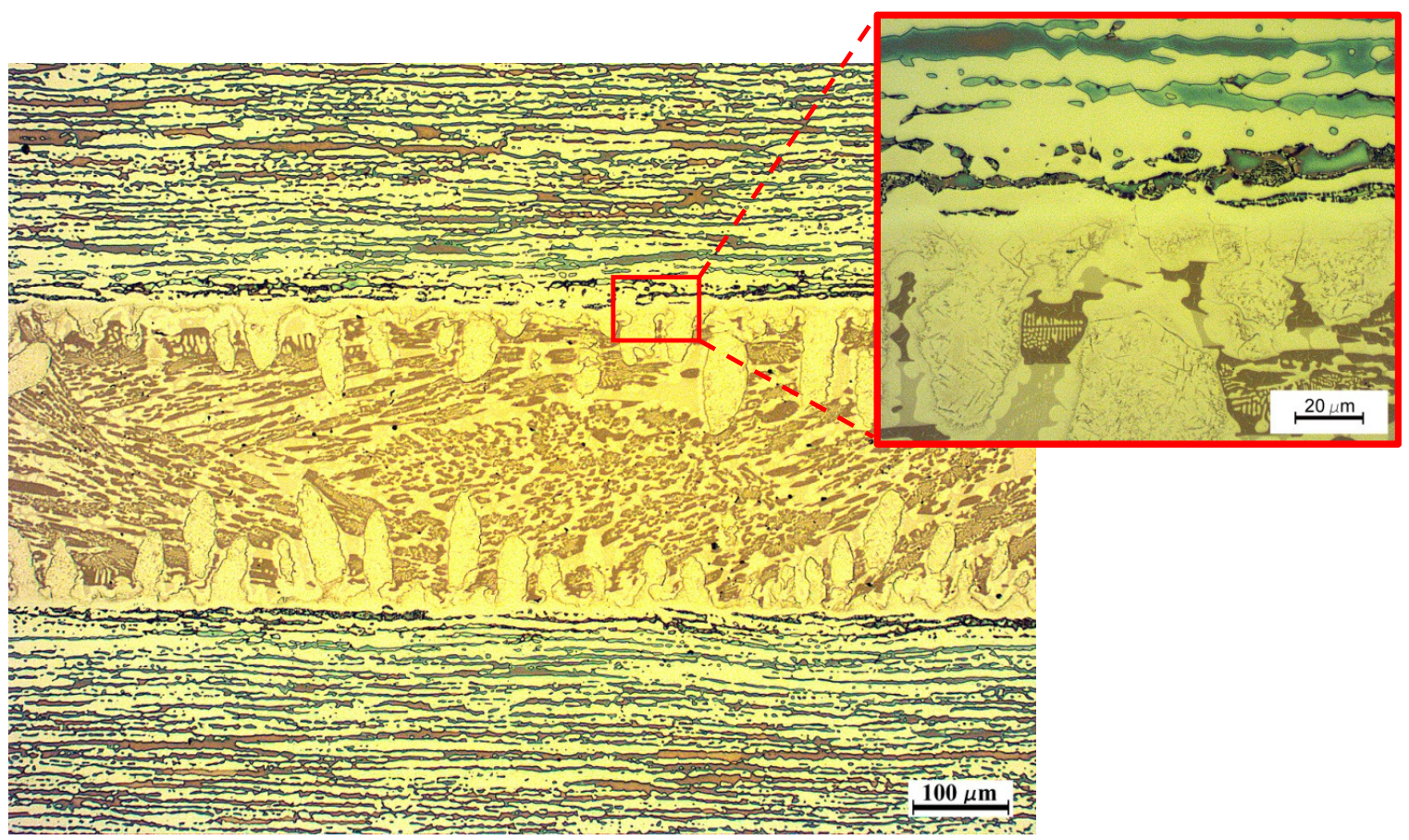

Figura 5.8 - Microestrutura da junta brasada obtida por microscopia óptica do AID. UNS S32750 para um tamanho de folga de $0,3 \mathrm{~mm}$. No detalhe se observa a região da interface da junta.

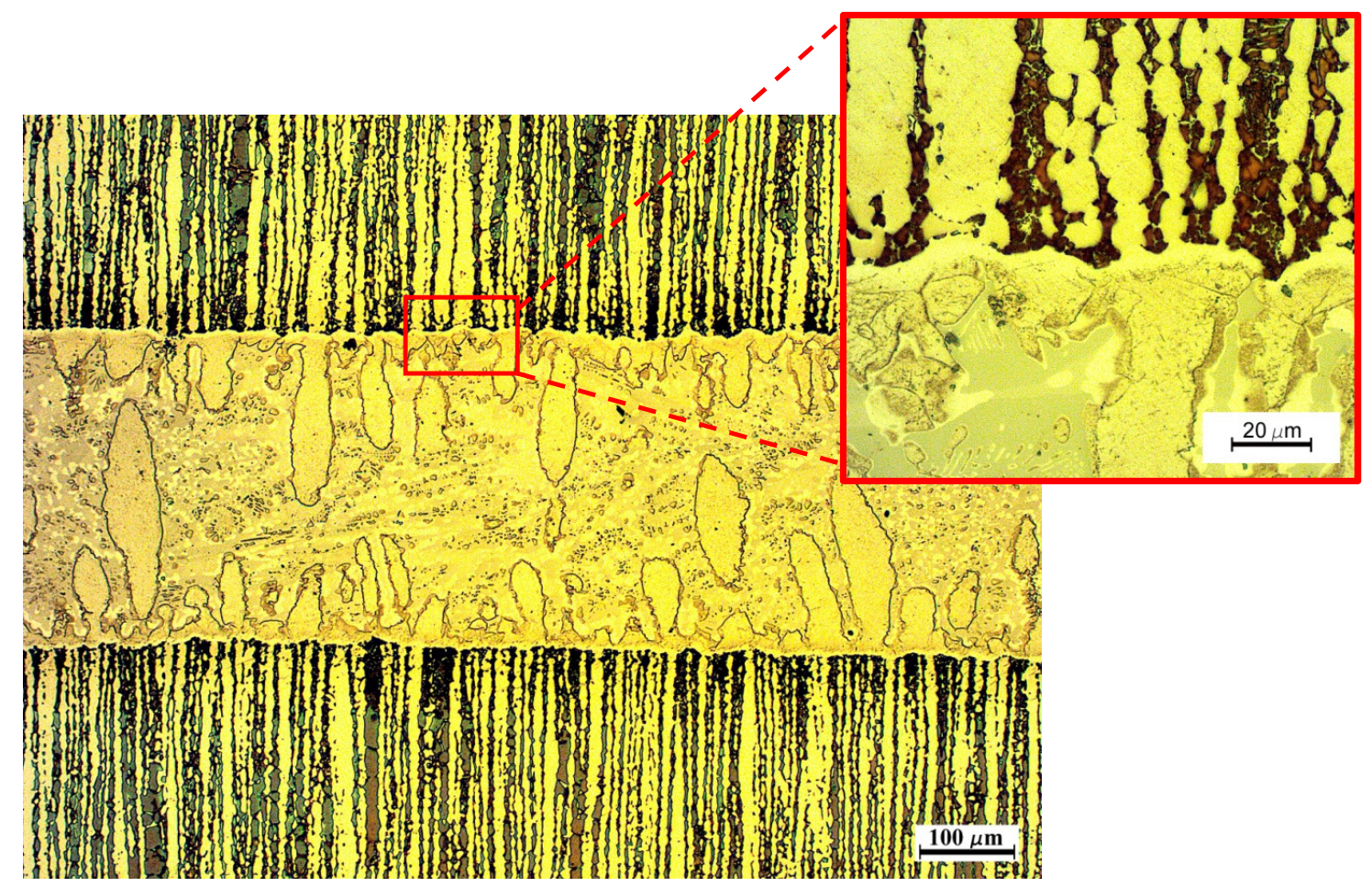

Figura 5.9 - Microestrutura da junta brasada obtida por microscopia óptica do AID. UNS S32707 para um tamanho de folga de $0,3 \mathrm{~mm}$. No detalhe se observa a região da interface da junta. 


\section{Análise microestrutural condição 3 : tempo $32 \mathrm{~min}$ e folga $0,0 \mathrm{~mm}$}

Apresenta-se nas figuras 5.10 a 5.13 , a microestrutura da região brasada dos AID's analisados. Com a diminuição no tamanho da folga a microestrutura da junta apresenta uma morfologia totalmente diferente à verificada nas outras condições com tamanho de folga maior. Observando as figura 5.10 a 5.13 , percebe-se que a região brasada em todos os casos, está principalmente composta pela solução sólida rica em níquel. Contudo, existe a presença de pequenas "ilhas" de intermetálicos, distribuídos no centro da junta brasada.

De igual forma ao observado nas duas condições anteriores, o AISD e AIHD (figura 5.12 e 5.13) apresentam decomposição da fase ferrítica em possível fase sigma na região da interface. No entanto, a extensão desta decomposição ficou notavelmente maior para o AISD UNS S32750 (figura 5.12) quando comparado com as outras duas condições. Em contrapartida o AIHD UNS S32707 (figura 5.13) aparenta uma diminuição na formação desta fase.

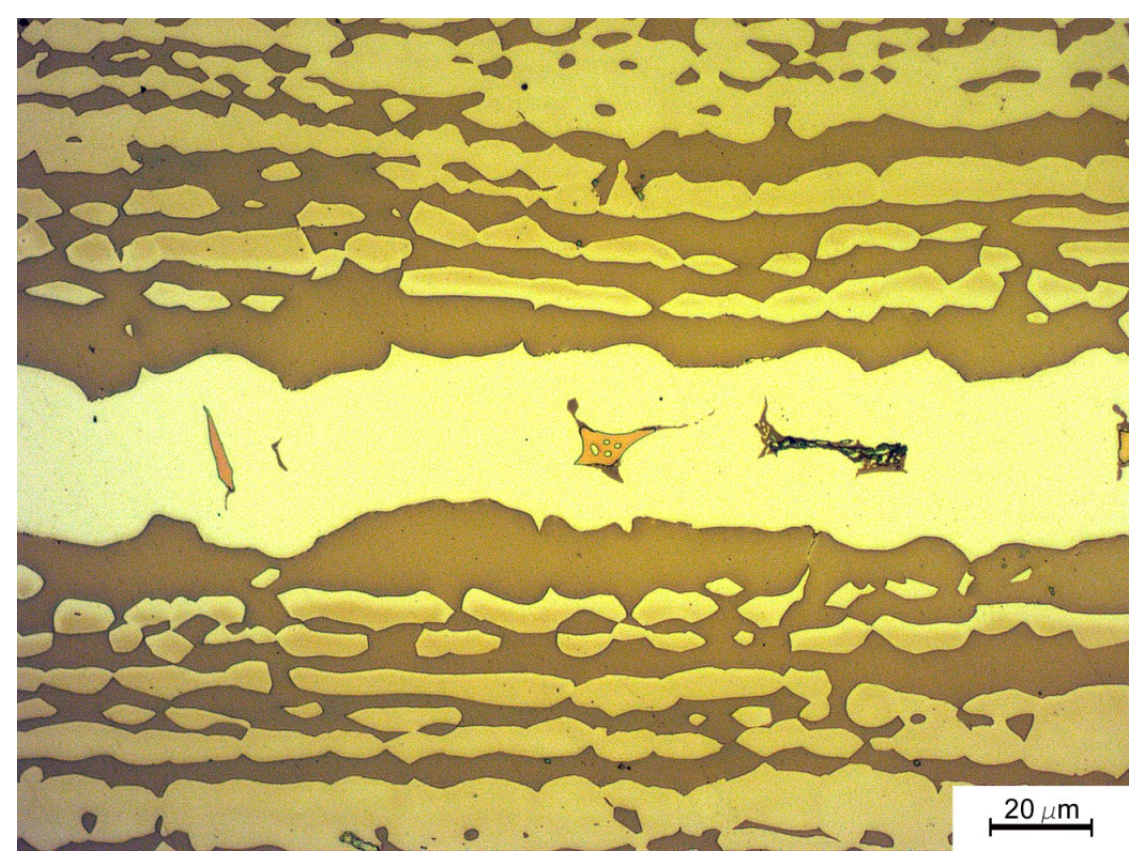

Figura 5.10 - Microestrutura da junta brasada obtida por microscopia óptica do AID. UNS S32101 para um tamanho de folga de $0,0 \mathrm{~mm}$. 


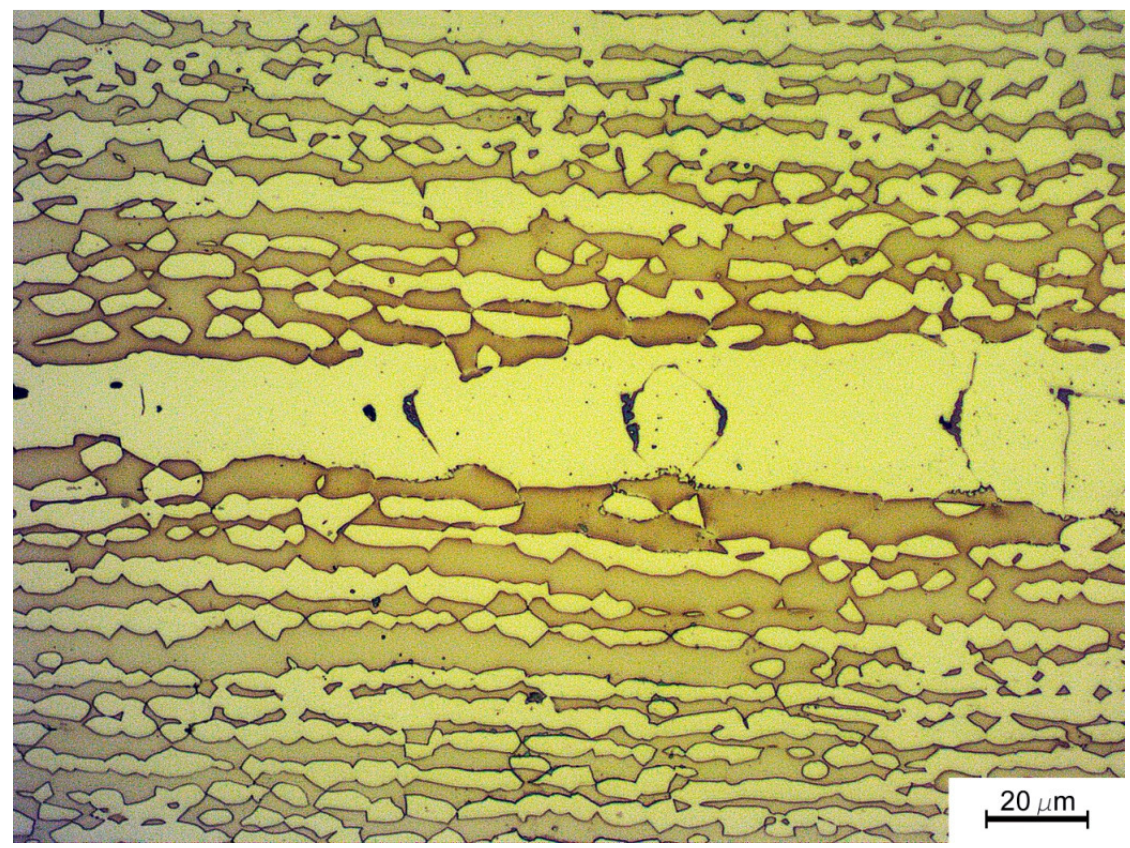

Figura 5.11 - Microestrutura da junta brasada obtida por microscopia óptica do AID. UNS S32304 para um tamanho de folga de $0,0 \mathrm{~mm}$.

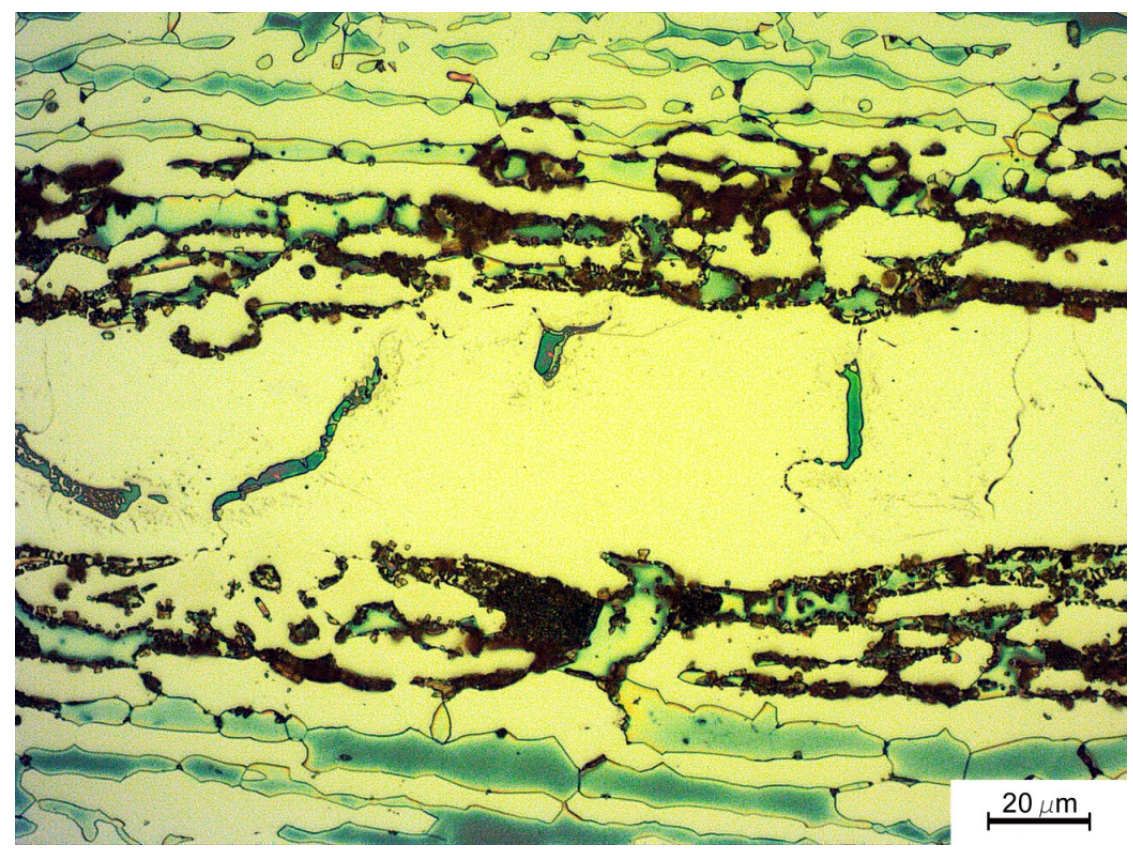

Figura 5.12 - Microestrutura da junta brasada obtida por microscopia óptica do AID. UNS S32750 para um tamanho de folga de $0,0 \mathrm{~mm}$. 


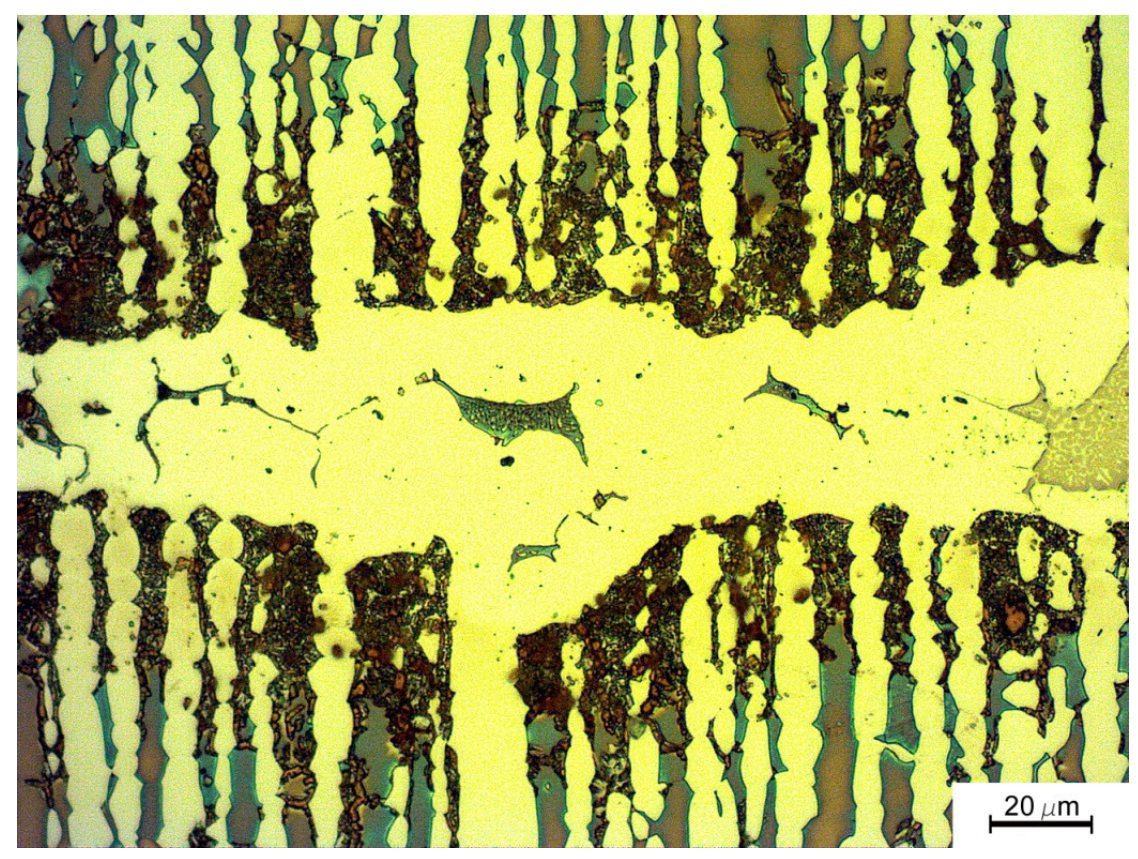

Figura 5.13 - Microestrutura da junta brasada obtida por microscopia óptica do AID. UNS S32707 para um tamanho de folga de $0,0 \mathrm{~mm}$.

\section{Análise microestrutural condição 4: tempo 12 min e folga $0,5 \mathrm{~mm}$}

Mostra-se nas figuras 5.14 a 5.17, a microestrutura da região brasada dos AID's UNS S32101, UNS S32304, UNS S32750 e UNS S32707.

Verifica-se que, assim como nas anteriores condições, apesar da diminuição do tempo de brasagem para 12 min aproximadamente, a interação metal base e metal de adição é boa, visto que, não se observa defeitos pronunciados ao longo da junta para os diferentes AID's brasados, como se pode verificar nas figuras 5.14 a 5.17.

Analisando a região central da junta, percebe-se para todos os casos a formação de uma grande proporção de intermetálicos e fase eutética distribuída na junta brasada. Por outro lado, a solução solida rica em níquel aparece de forma mais discreta nos AID baixa liga UNS S32101 e UNS S32304, já o AISD UNS S32750 e o AIHD e UNS S32707 apresentam claramente uma maior quantidade desta fase.

Para esta condição a camada de fase austenítica formada no metal base próxima à zona de interface é muito mais fina. 


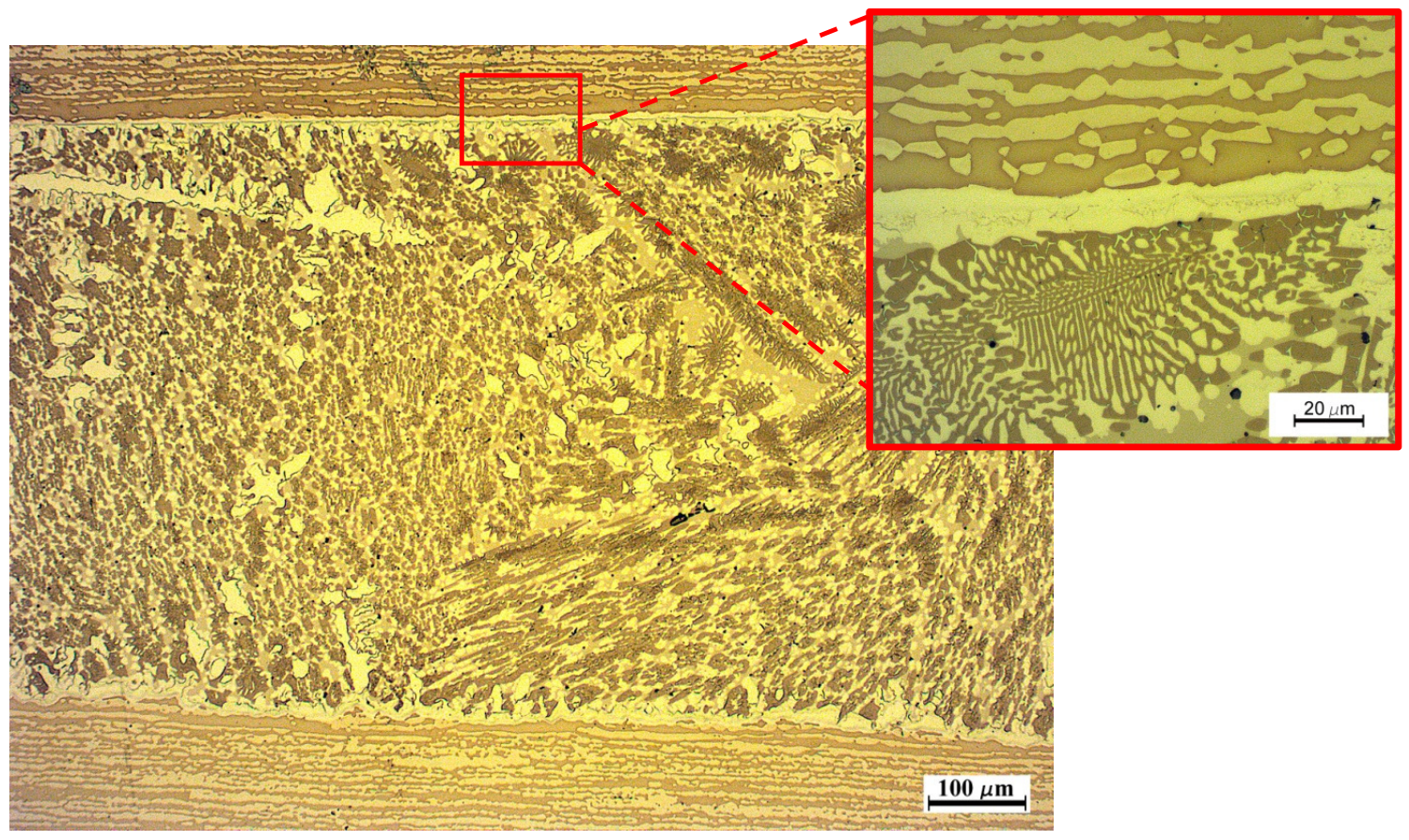

Figura 5.14 - Microestrutura da junta brasada obtida por microscopia óptica do AID. UNS S32101 para um tamanho de folga de $0,5 \mathrm{~mm}$. No detalhe se observa a região da interface da junta.

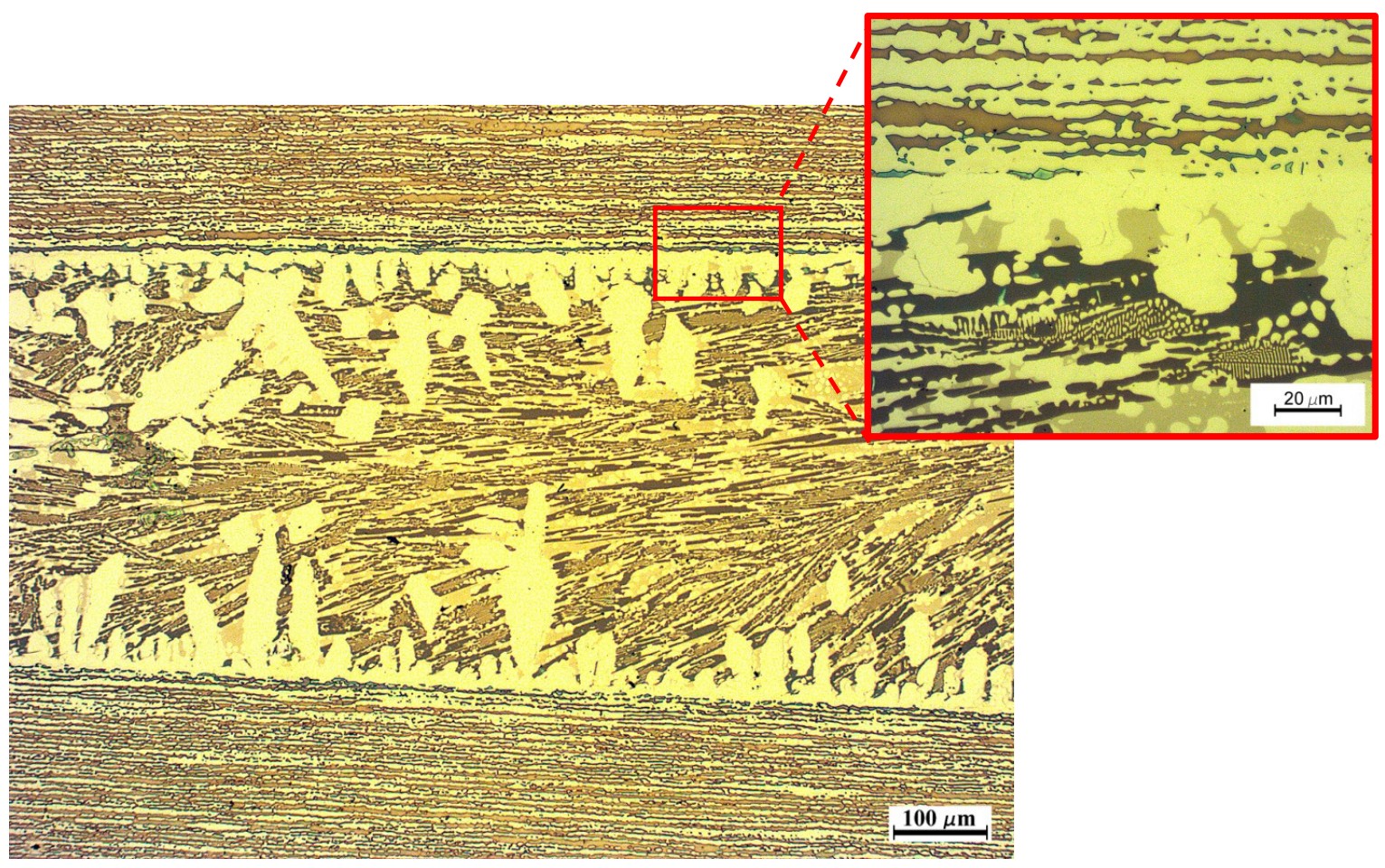

Figura 5.15 - Microestrutura da junta brasada obtida por microscopia óptica do AID. UNS S32304 para um tamanho de folga de $0,5 \mathrm{~mm}$. No detalhe se observa a região da interface da junta. 


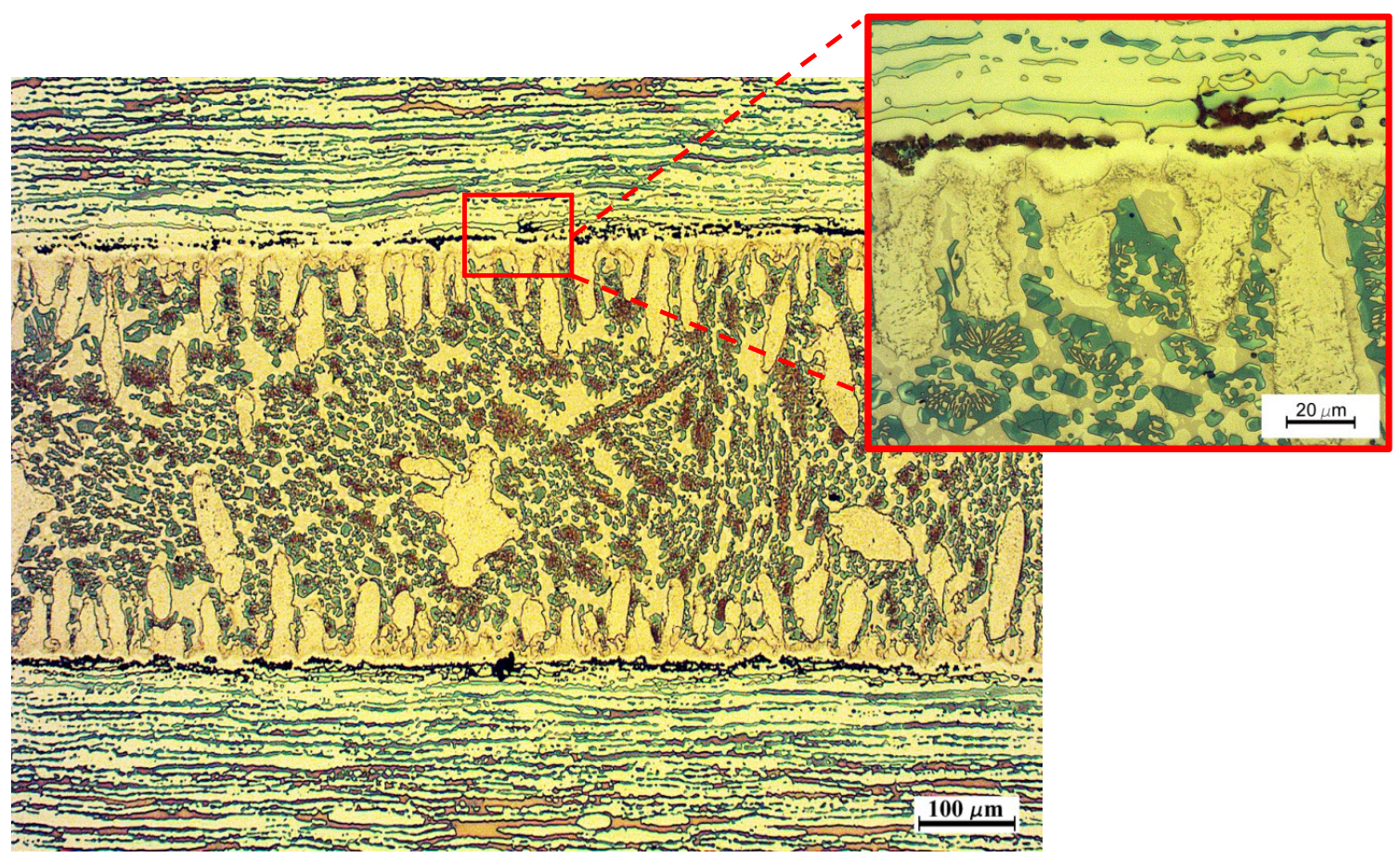

Figura 5.16 - Microestrutura da junta brasada obtida por microscopia óptica do AID. UNS S32750 para um tamanho de folga de $0,5 \mathrm{~mm}$. No detalhe se observa a região da interface da junta.

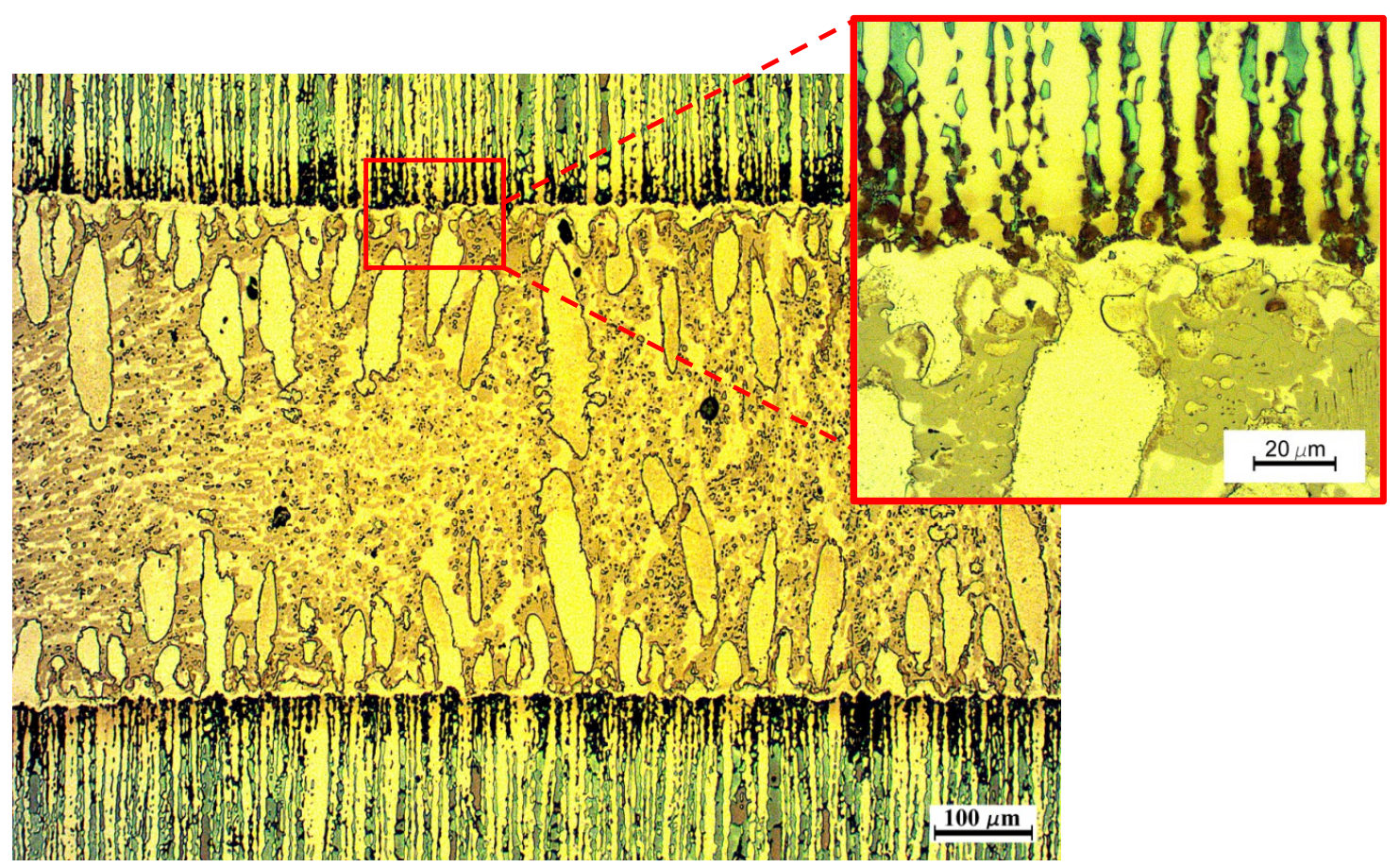

Figura 5.17 - Microestrutura da junta brasada obtida por microscopia óptica do AID. UNS S32707 para um tamanho de folga de $0,5 \mathrm{~mm}$. No detalhe se observa a região da interface da junta. 


\section{E. Análise microestrutural condição 5: tempo $12 \mathrm{~min}$ e folga $0,3 \mathrm{~mm}$}

Apresentam-se nas figuras 5.18 a 5.21 as microfotografias obtidas para esta condição da região brasada dos AID's em estudo.

Com diminuição do tamanho da folga e tempo de brasagem, pode-se verificar de forma geral que para todos os AID's a solução sólida rica em níquel desenvolveu-se em menor proporção quando comparada com a condição anterior. Já o AID UNS S32101 apresenta uma ligeira maior quantidade desta fase, porem mantém a tendência de diminuição comparada com a condição anterior.

Constata-se que apesar da diminuição do tempo de brasagem, persiste a decomposição da ferrita em provável fase sigma no AISD UNS S32750 e AIHD UNS S32707 (figura 5.6c e 5.6d) não se verificando este fenômeno para os AID baixa liga.

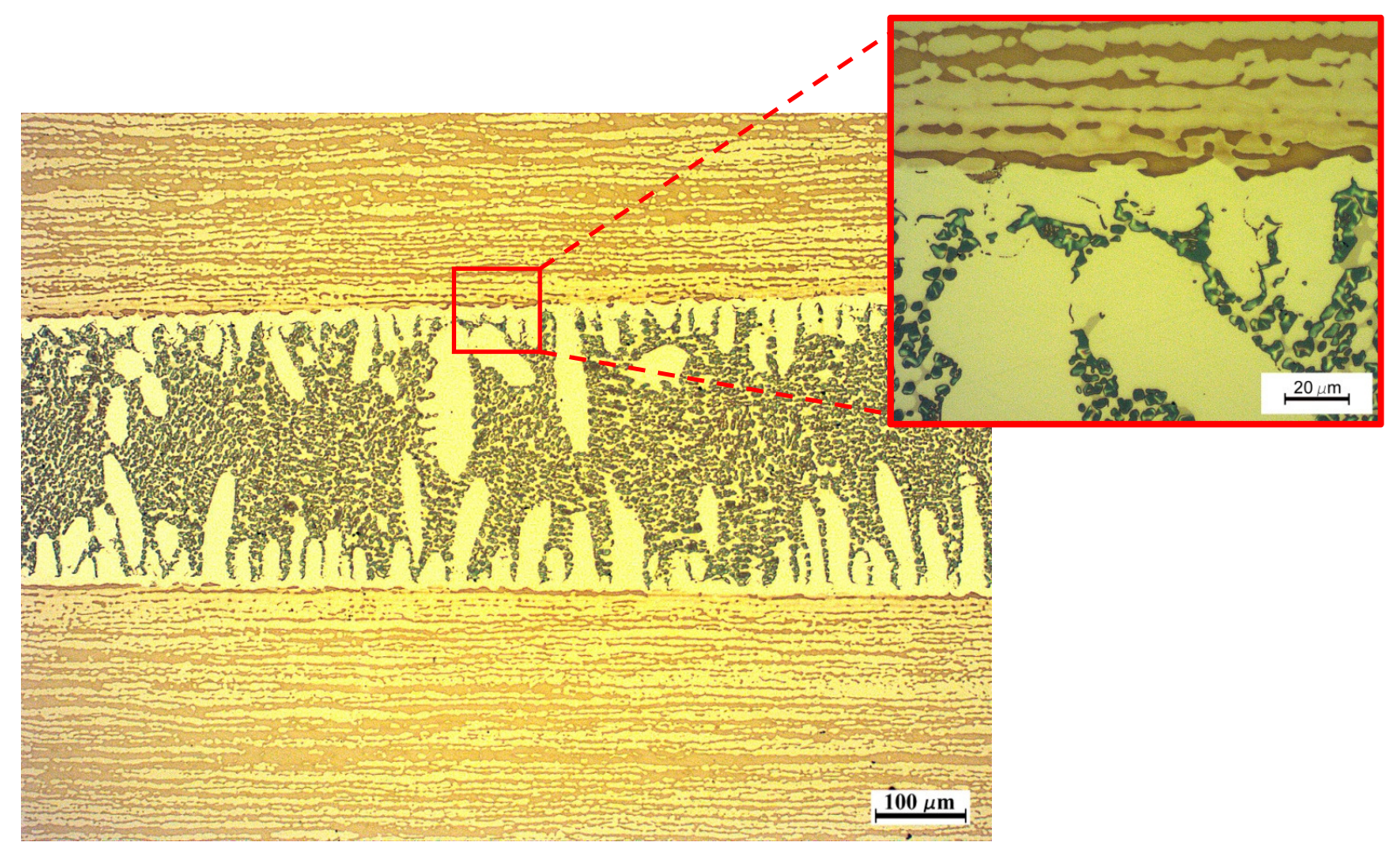

Figura 5.18 - Microestrutura da junta brasada obtida por microscopia óptica do AID. UNS S32101 para um tamanho de folga de $0,3 \mathrm{~mm}$. No detalhe se observa a região da interface da junta. 


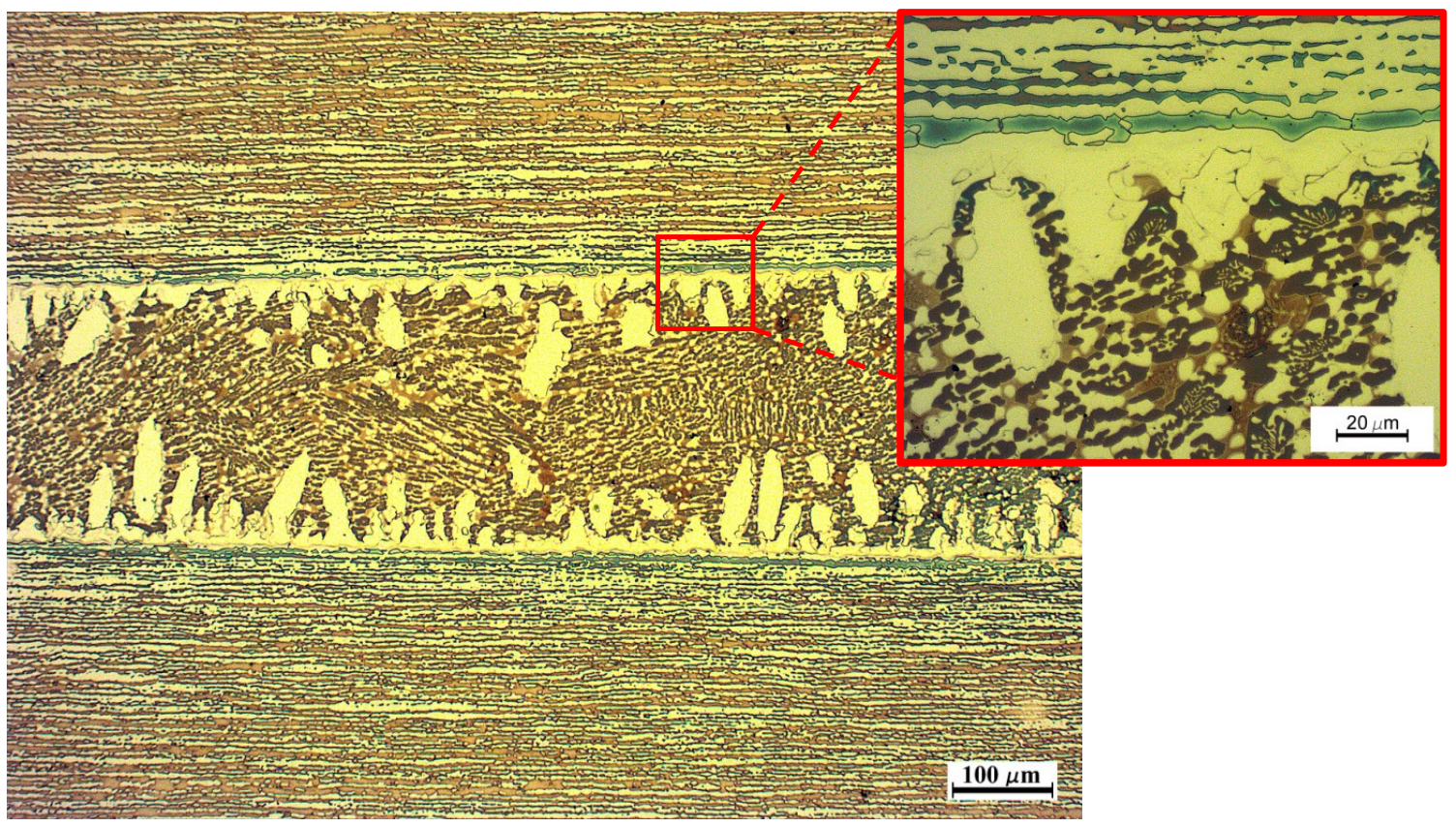

Figura 5.19 - Microestrutura da junta brasada obtida por microscopia óptica do AID. UNS S32304 para um tamanho de folga de $0,3 \mathrm{~mm}$. No detalhe se observa a região da interface da junta.

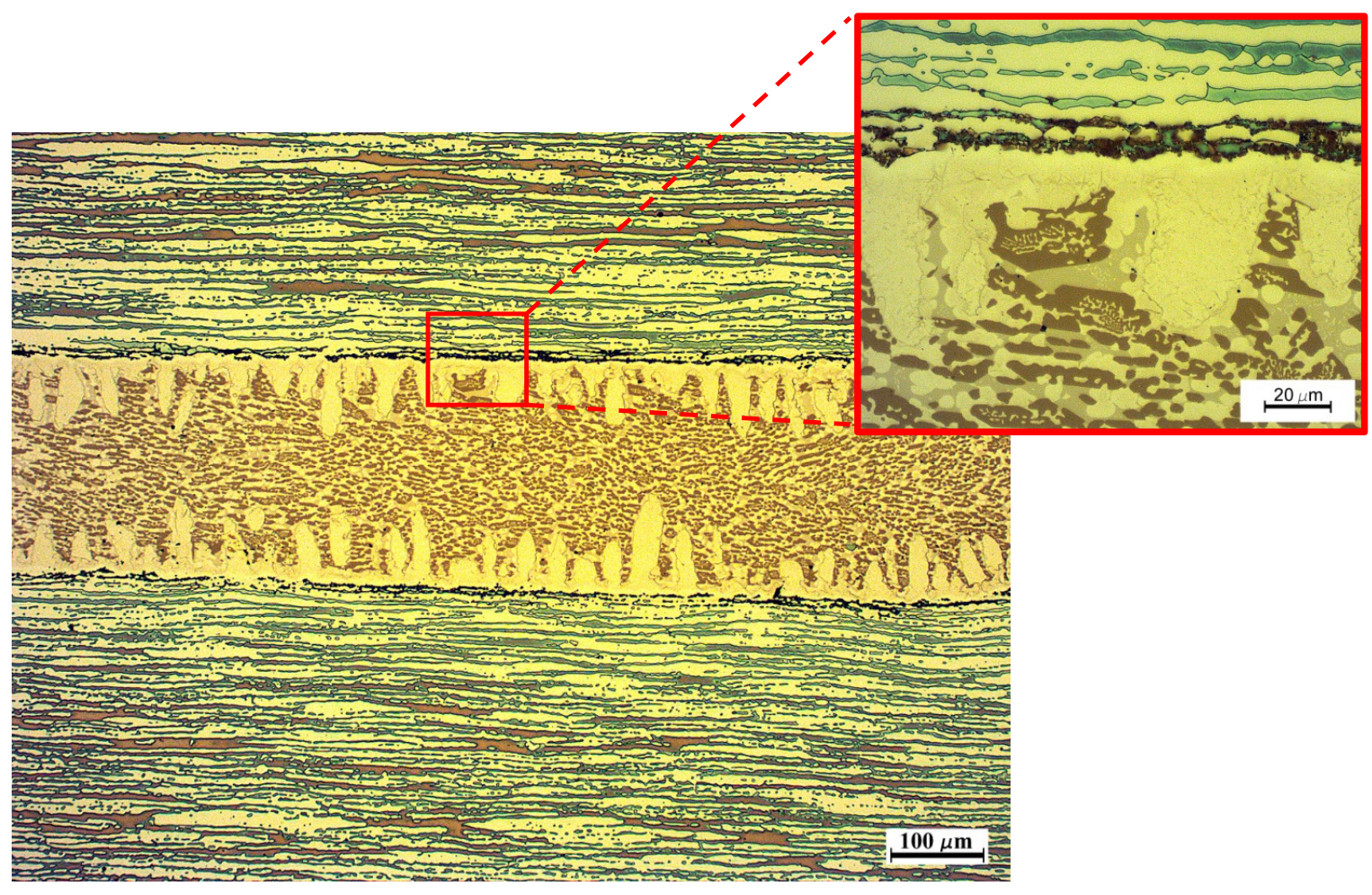

Figura 5.20 - Microestrutura da junta brasada obtida por microscopia óptica do AID. UNS S32750 para um tamanho de folga de $0,3 \mathrm{~mm}$. No detalhe se observa a região da interface da junta. 


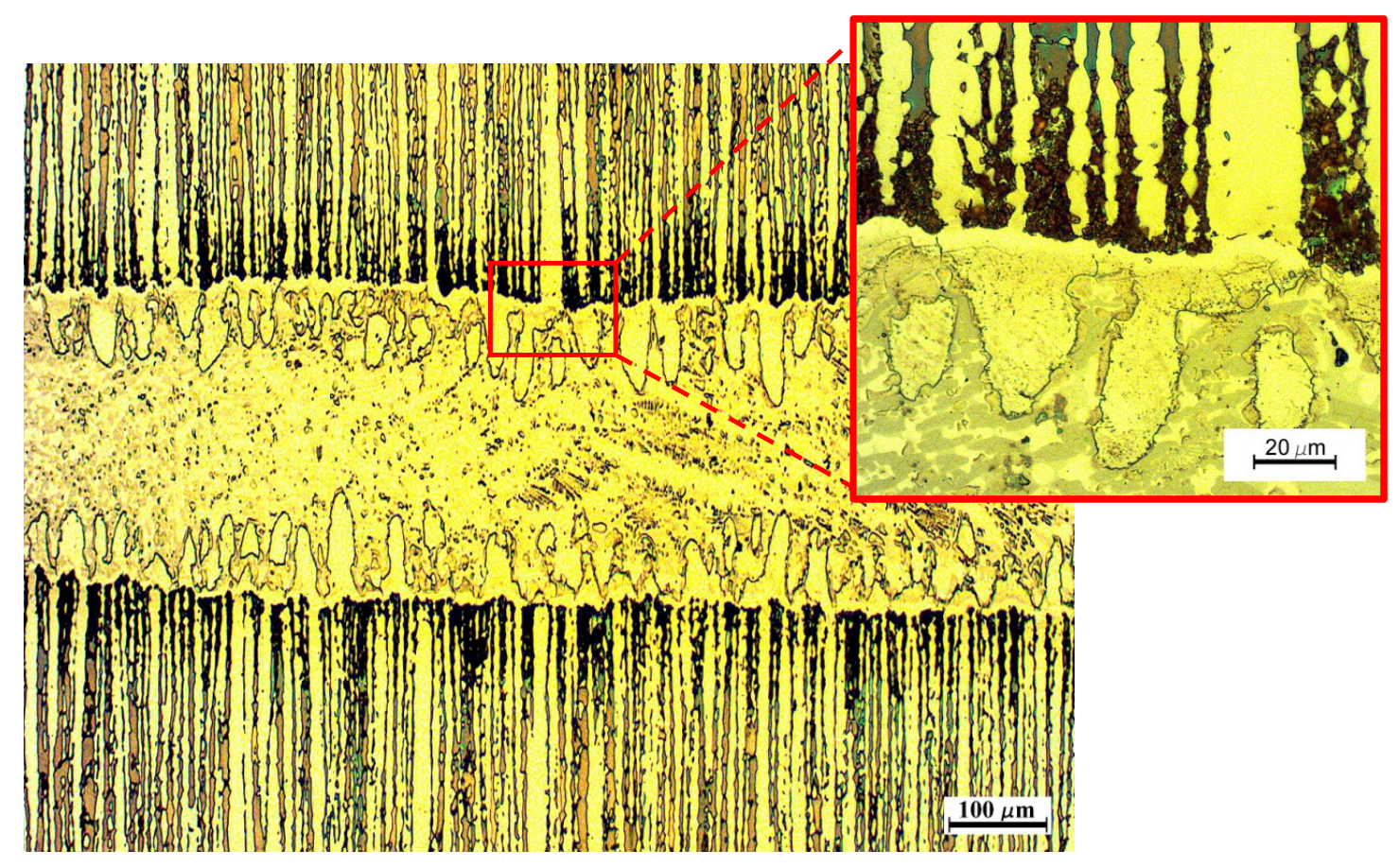

Figura 5.21 - Microestrutura da junta brasada obtida por microscopia óptica do AID. UNS S3707 para um tamanho de folga de $0,3 \mathrm{~mm}$. No detalhe se observa a região da interface da junta.

\section{F. Análise microestrutural condição 6: tempo $12 \mathrm{~min}$ e folga $0,0 \mathrm{~mm}$}

As figuras 5.22 a 5.25 apresentam a microestrutura da região brasada dos AID's UNS S32101, UNS S32304, UNS S32750 e UNS S32707.

Assim como para condição 3 , nesta condição a microestrutura da junta brasada está formada principalmente composta pela solução sólida rica em níquel. Porém, existe uma maior presença de intermetálicos, sendo distribuídos de forma mais contínua na região central da junta. Desta forma, o AISD UNS S32707 mostra a formação acentuada desta linha continua de intermetálicos.

Para esta condição constata-se também que o AISD e AIHD (figura 5.24 e 5.25) apresentam na região próxima à zona brasada, a decomposição da fase ferrítica em uma fase escura que pelas suas características, como foi mencionado anteriormente, poder-se-ia tratar da fase sigma. Esta decomposição, uma vez mais é apreciada no AID UNS S32707, porém em uma maior proporção, estendendo-se em quase todo o metal base. 


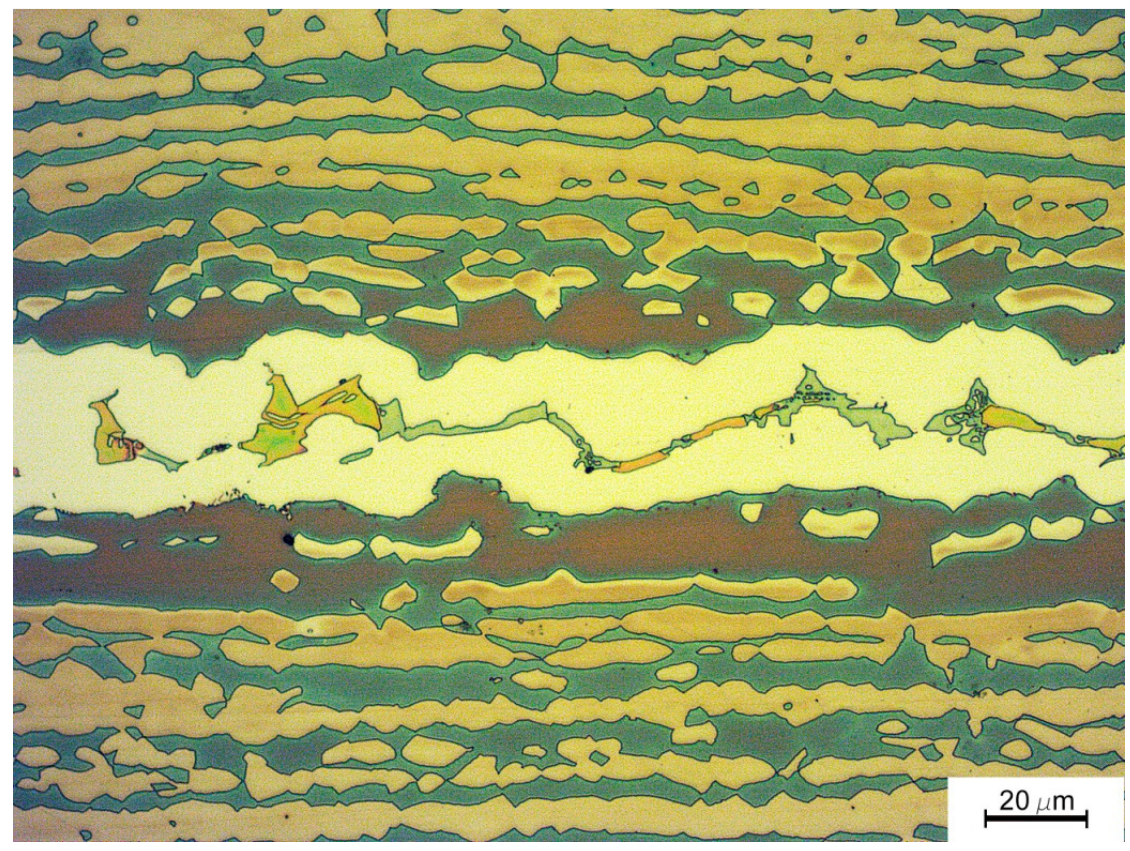

Figura 5.22 - Microestrutura da junta brasada obtida por microscopia óptica do AID. UNS S32101 para um tamanho de folga de $0,0 \mathrm{~mm}$.

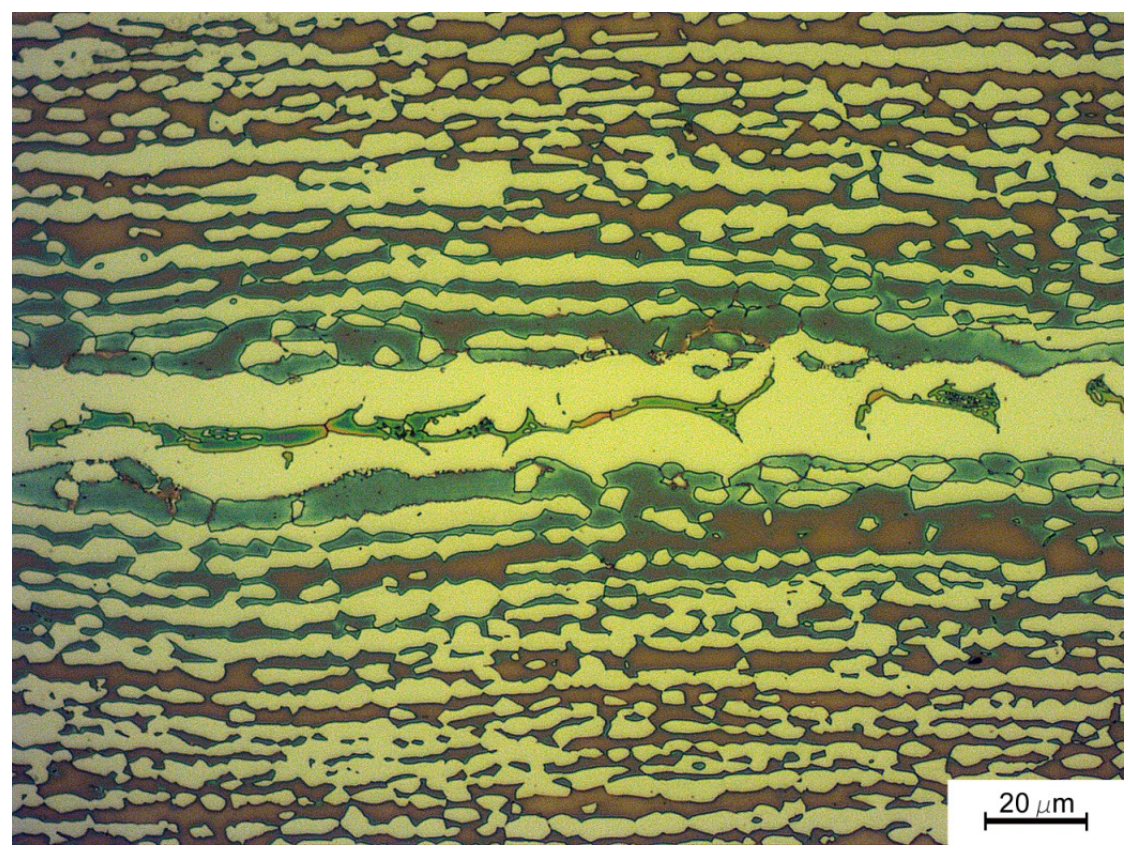

Figura 5.23 - Microestrutura da junta brasada obtida por microscopia óptica do AID. UNS S32304 para um tamanho de folga de $0,0 \mathrm{~mm}$. 


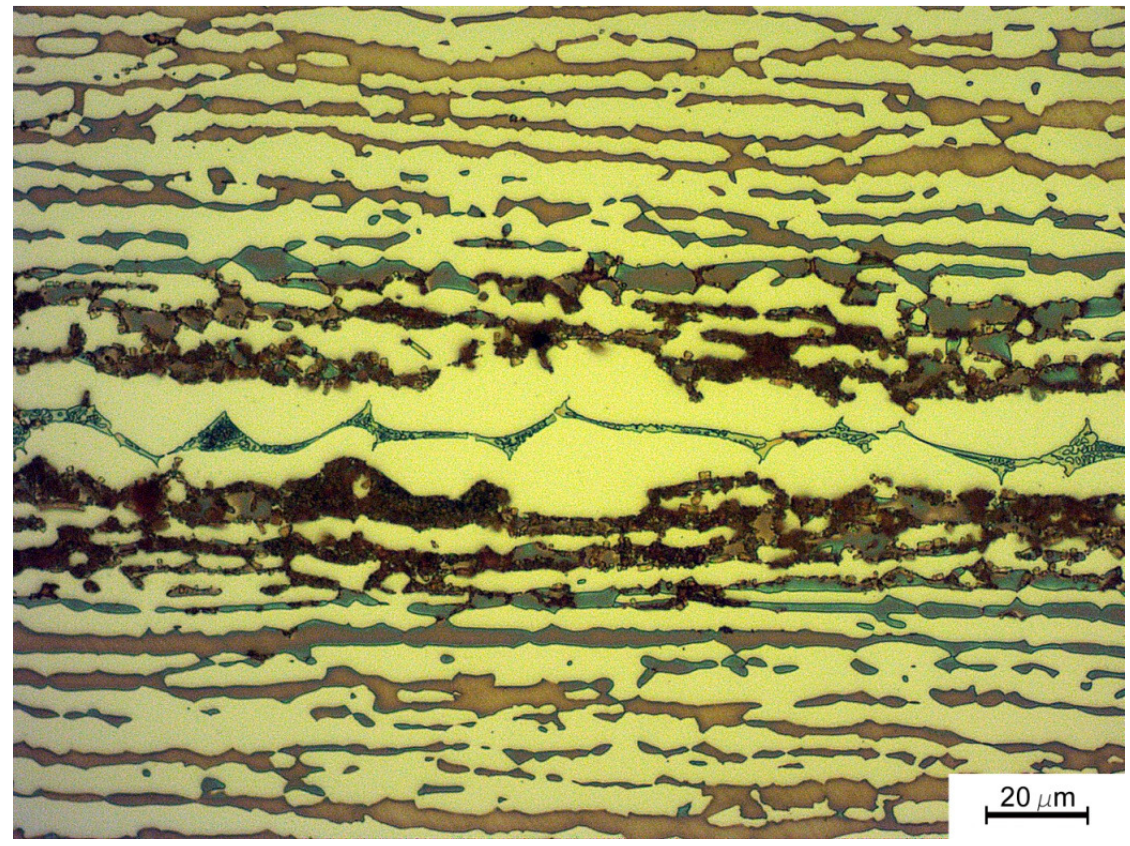

Figura 5.24 - Microestrutura da junta brasada obtida por microscopia óptica do AID. UNS S32750 para um tamanho de folga de $0,0 \mathrm{~mm}$.

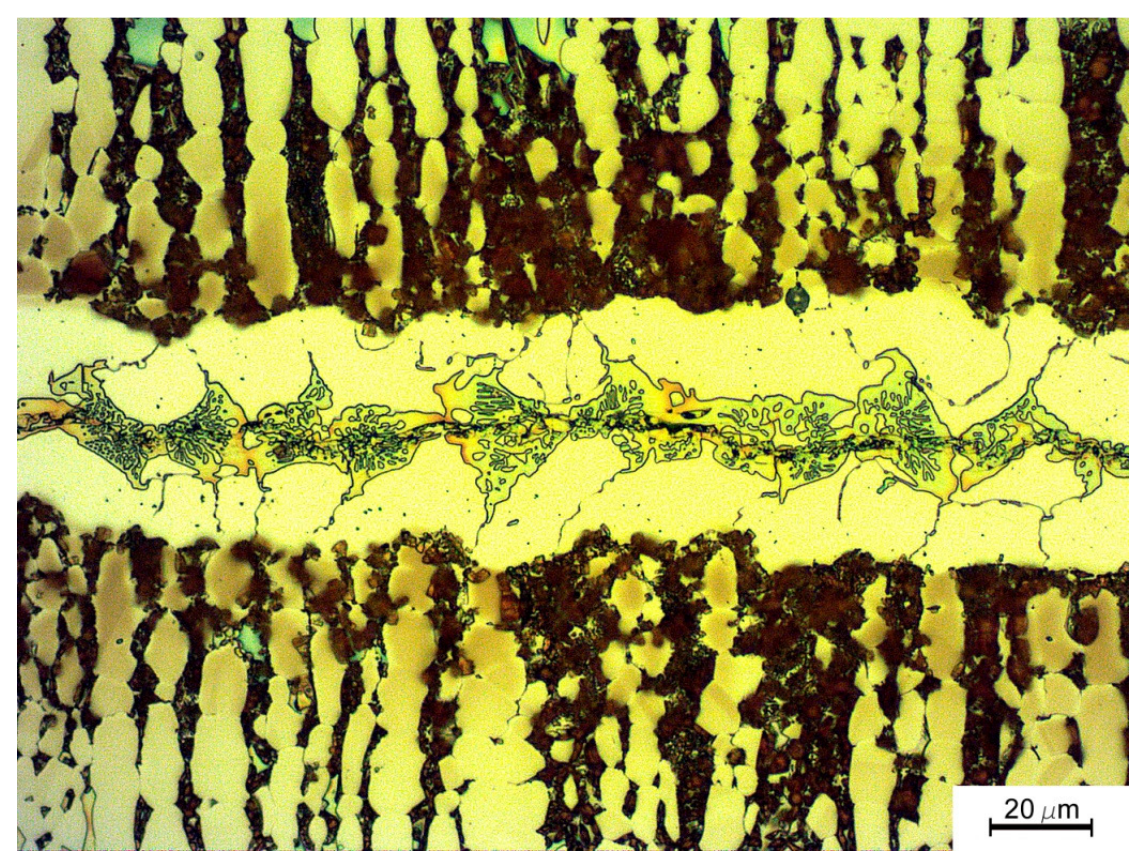

Figura 5.25 - Microestrutura da junta brasada obtida por microscopia óptica do AID. UNS S32707 para um tamanho de folga de $0,0 \mathrm{~mm}$. 


\subsubsection{Microscopia Eletrônica de Varredura (MEV)}

Analisou-se a microestrutura da junta brasada dos diferentes AID's mediante o uso de imagens de elétrons retroespalhados (BSE). Através desta técnica, pode-se observar as diferentes fases quando associadas aos elementos que as formam. Já que, como mencionado no item 4.6.2, a diferença de contraste entre cada fase, corresponde à variação no peso atômico dos elementos que as compõem. Além disso, foi utilizada a técnica de espectroscopia de energia dispersiva de raios $X$ (EDS) para a microanálise química das fases. A coleta de dados para a análise quantitativa foi realizada em cinco pontos diferentes para cada fase observada na região da junta brasada, com folga de 0,5 e 0,3 $\mathrm{mm}$. Entretanto, cabe mencionar que pela morfologia diferenciada da junta com folga de $0,0 \mathrm{~mm}$ foi realizada a análise em três pontos diferentes das fases presentes, como será verificado na continuação.

A presente seção segue o critério de comparação entre os AID's para cada condição de brasagem, tal como foi apresentado no item 5.1.1.2.

\subsubsection{Condição 1: tempo de $32 \mathrm{~min}$ e $0,5 \mathrm{~mm}$ de folga}

Nas figuras 5.26 a 5.29 são apresentadas as micrografias tanto em uma visão geral assim como em uma visão detalhada da junta brasada dos AID em questão. Observa-se que para os quatro materiais foram identificadas três fases notavelmente diferenciadas por sua tonalidade. Sendo, estas fases marcadas como "a", "b" e "c", de tonalidade cinza claro, intermediário e escuro, respectivamente.

Verifica-se em todos os casos que a fase marcada como "a" representa a solução sólida rica em níquel, já a fase "b" e "c" tratam-se de compostos intermetálicos com altos teores de fósforo. A composição química de cada fase é mostrada nas tabelas 5.1 a 5.4 logo em seguida das micrografias para cada material. Nota-se nas micrografias para todos os AID analisados, que a fase com maior presença na 
região da junta é a solução sólida rica em níquel ("a"), seguida da fase escura ("b") e por último a fase intermediária ("c").

Observam-se nos AID UNS S32750 e UNS S32707, figuras 5.28 e 5.29, respectivamente, a presença de um campo "E" formado por fases lamelares da fase rica em níquel "a" contidas dentro da fase cinza escura "c" com morfologia característica de fases eutéticas. Assim, verifica-se uma maior quantidade destes campos no aço UNS S32707 do que no UNS S32750.

Apesar da diferença entre os tipos de AID's pertinente a seus teores de elementos de liga (baixa liga e alta liga), os resultados da relação $[(\mathrm{Ni}+\mathrm{Cr}) / \mathrm{P}]$ e $(\mathrm{Ni} / \mathrm{P})$ das fases "b" e "c" apresentam proximidade de valores, conforme visto nas tabelas 5.1 a 5.4.

- UNS S32101

(a)

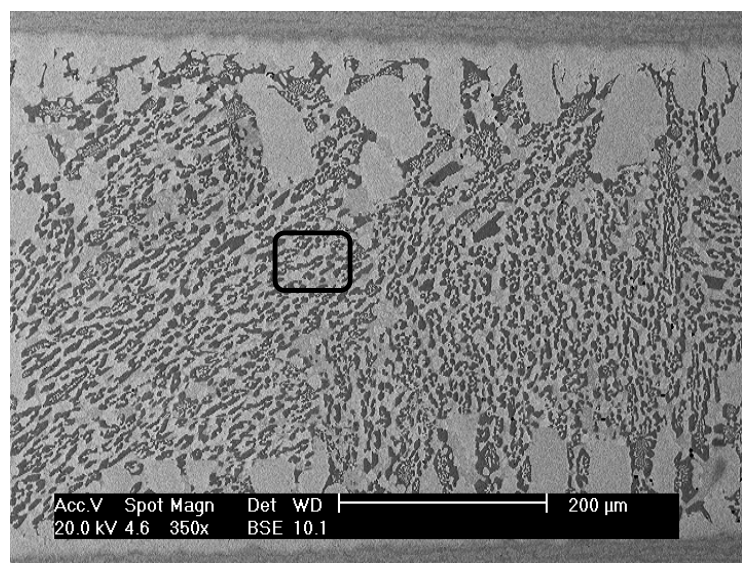

(b)

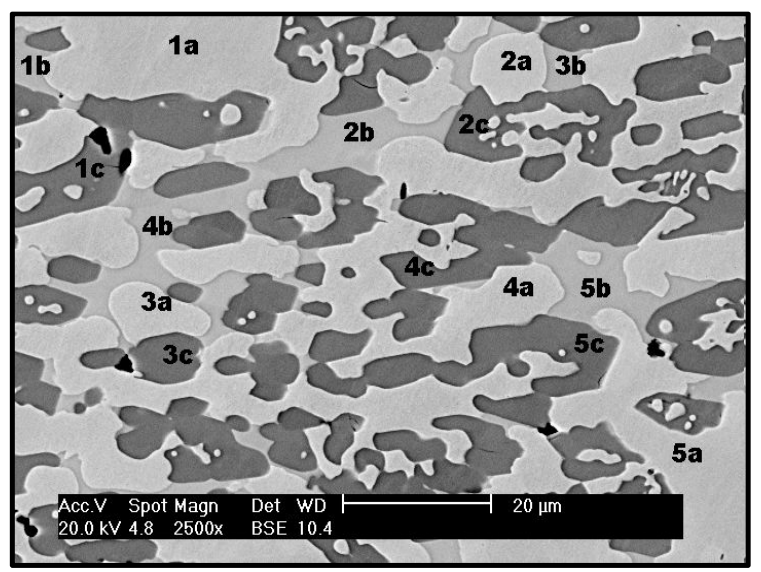

Figura 5.26 - Micrografias por MEV da região da junta brasada do AID UNS S32101. Em a) vista geral e b) ampliação região interna.

Tabela 5.1 - Análise química via EDS das fases identificadas na junta brasada do AID UNS S32101.

\begin{tabular}{cccccccc}
\hline \multirow{2}{*}{ Região } & \multicolumn{6}{c}{ Composição Química (at.\%) } & \multicolumn{2}{c}{ Relação } & Relação \\
\cline { 2 - 7 } & $\mathrm{Ni}$ & $\mathrm{Fe}$ & $\mathrm{Cr}$ & $\mathrm{P}$ & $\mathrm{Si}$ & {$[(\mathrm{Ni}+\mathrm{Cr}) / \mathrm{P}]$} & $(\mathrm{Ni} / \mathrm{P})$ \\
\hline a & 58,53 & 27,12 & 11,63 & 1,41 & 1,30 & - & - \\
\hline $\mathrm{b}$ & 58,00 & 9,21 & 7,34 & 23,78 & 1,68 & - & 2.45 \\
\hline $\mathrm{c}$ & 27,81 & 8,95 & 29,36 & 31,92 & 1,96 & 1,79 & - \\
\hline
\end{tabular}


- UNS S32304

(a)

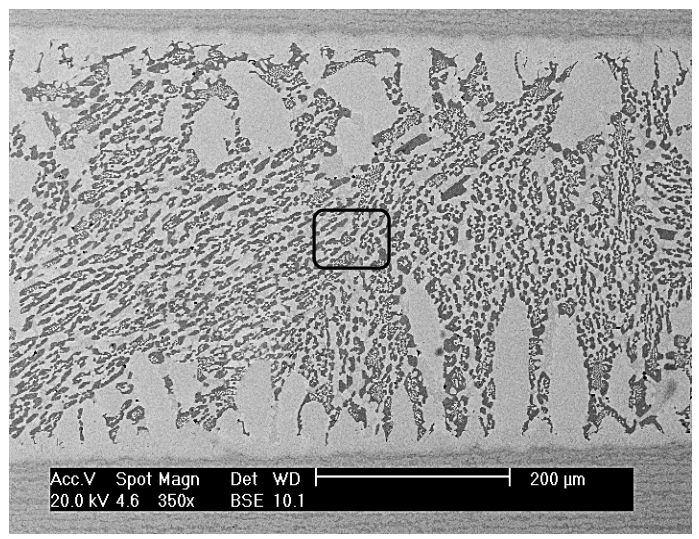

(b)

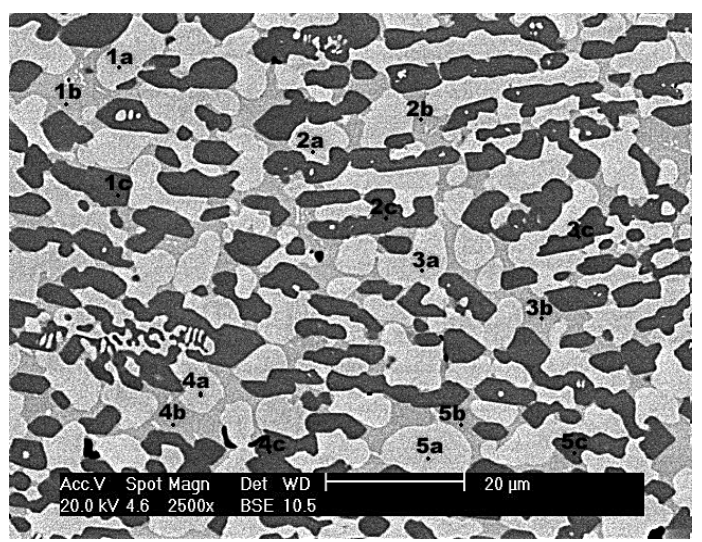

Figura 5.27 - Micrografias por MEV da região da junta brasada do AID UNS S32304. Em a) vista geral e b) ampliação região interna.

Tabela 5.2 - Análise química via EDS das fases identificadas na junta brasada do AID UNS S32304.

\begin{tabular}{cccccccc}
\hline \multirow{2}{*}{ Região } & \multicolumn{9}{c}{ Composição Química (at.\%) } & Relação & Relação \\
\cline { 2 - 6 } & $\mathrm{Ni}$ & $\mathrm{Fe}$ & $\mathrm{Cr}$ & $\mathrm{P}$ & $\mathrm{Si}$ & {$[(\mathrm{Ni}+\mathrm{Cr}) / \mathrm{P}]$} & $(\mathrm{Ni} / \mathrm{P})$ \\
\hline a & 60,00 & 25,84 & 11,38 & 1,48 & 1,30 & - & - \\
\hline b & 58,91 & 8,76 & 7,25 & 23,24 & 1,84 & - & 2,53 \\
\hline c & 29,54 & 8,42 & 29,05 & 31,17 & 1,83 & 1,88 & - \\
\hline
\end{tabular}

- UNS S32750

(a)

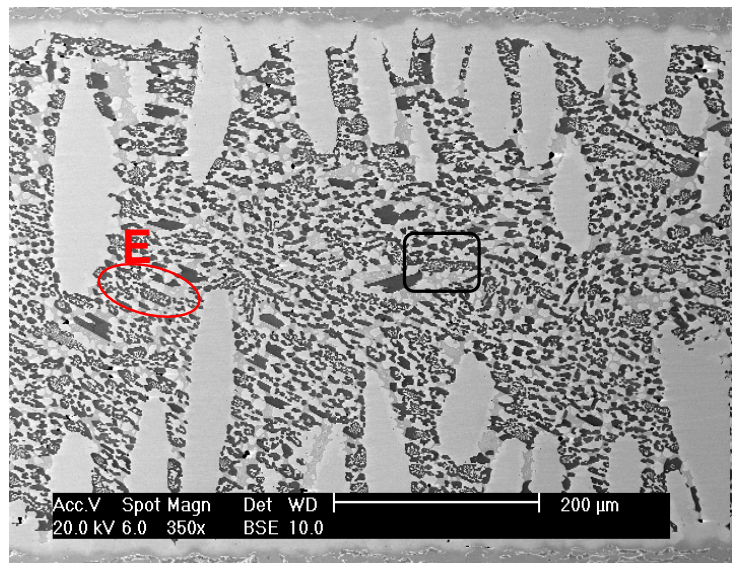

(b)

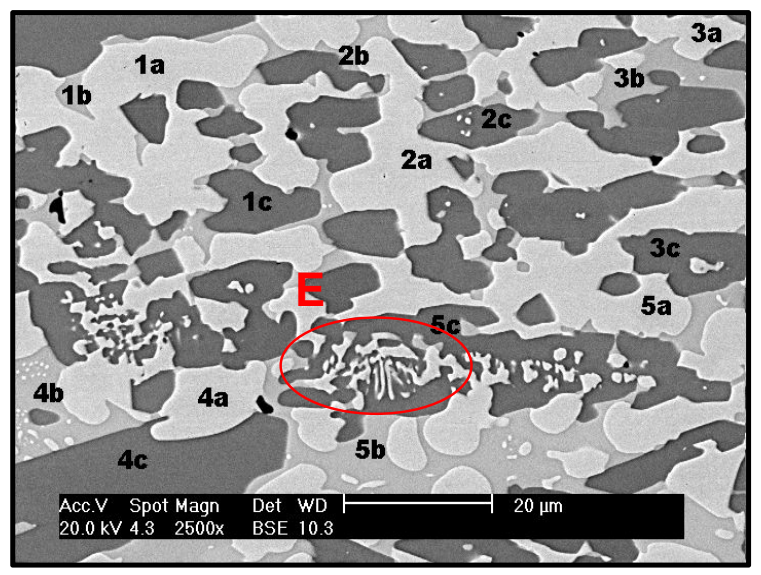

Figura 5.28 - Micrografias por MEV da região da junta brasada do AID UNS S32750. Em a) vista geral e b) ampliação região interna. 
Tabela 5.3 - Análise química via EDS das fases identificadas na junta brasada do AID UNS S32750.

\begin{tabular}{cccccccc}
\hline \multirow{2}{*}{ Região } & \multicolumn{9}{c}{ Composição Química (at.\%) } & Relação & Relação \\
\cline { 2 - 6 } & $\mathrm{Ni}$ & $\mathrm{Fe}$ & $\mathrm{Cr}$ & $\mathrm{P}$ & $\mathrm{Si}$ & {$[(\mathrm{Ni}+\mathrm{Cr}) / \mathrm{P}]$} & (Ni /P) \\
\hline $\mathrm{a}$ & 64,12 & 20,37 & 13,18 & 1,42 & 0,91 & - & - \\
\hline $\mathrm{b}$ & 59,89 & 6,74 & 8,74 & 23,09 & 1,55 & - & 2,59 \\
\hline $\mathrm{c}$ & 32,18 & 5,63 & 28,54 & 31,98 & 1,68 & 1,9 & - \\
\hline
\end{tabular}

- UNS S32707

(a)

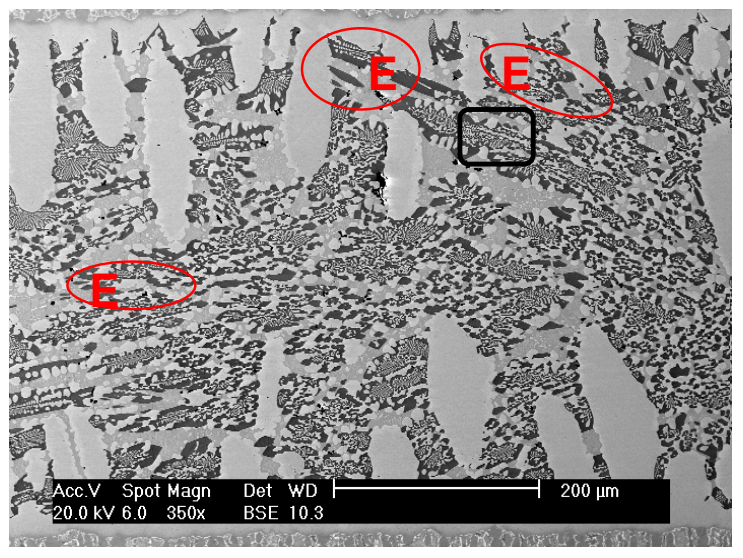

(b)

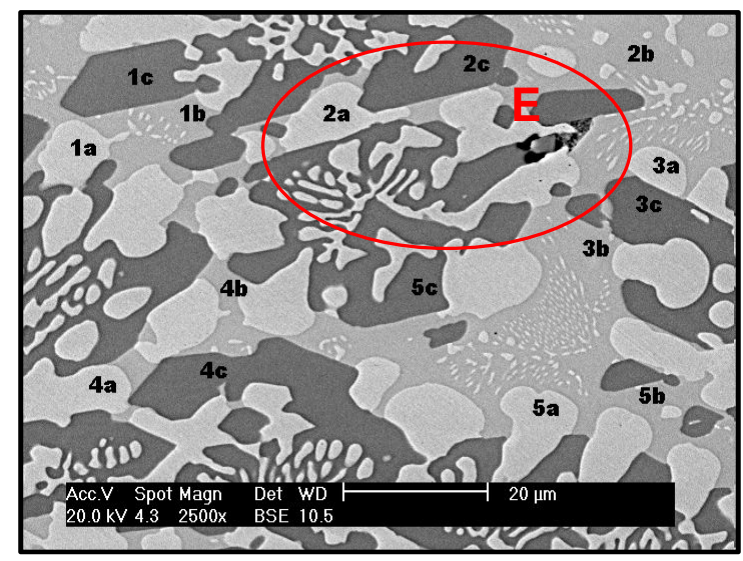

Figura 5.29 - Micrografias por MEV da região da junta brasada do AID UNS S32707. Em a) vista geral e b) ampliação região interna.

Tabela 5.4 - Análise química via EDS das fases identificadas na junta brasada do AID UNS S32707.

\begin{tabular}{|c|c|c|c|c|c|c|c|}
\hline \multirow{2}{*}{ Região } & \multicolumn{5}{|c|}{ Composição Química (at.\%) } & \multirow{2}{*}{$\begin{array}{c}\text { Relação } \\
{[(\mathrm{Ni}+\mathrm{Cr}) / \mathrm{P}]}\end{array}$} & \multirow{2}{*}{$\begin{array}{c}\text { Relação } \\
(\mathrm{Ni} / \mathrm{P})\end{array}$} \\
\hline & $\mathrm{Ni}$ & $\mathrm{Fe}$ & $\mathrm{Cr}$ & $P$ & $\mathrm{Si}$ & & \\
\hline$a$ & 67,01 & 19,27 & 11,13 & 1,43 & 0,89 & - & - \\
\hline $\mathrm{b}$ & 60,03 & 6,58 & 8,75 & 22,95 & 1,69 & - & 2,62 \\
\hline C & 32,84 & 5,33 & 29,04 & 32,09 & 1,71 & 1,93 & - \\
\hline
\end{tabular}

\subsubsection{Condição 2: tempo de $32 \mathrm{~min}$ e $0,3 \mathrm{~mm}$ de folga}

Expõem-se nas figuras 5.30 a 5.33 as micrografias dos quatro AID em estudo. Para esta condição apesar da diminuição do tamanho de folga, também são observadas as três fases anteriores que compõem a microestrutura da junta. Correspondendo a 
fase marcada como "a", a solução sólida rica em níquel, as fases "b" e "c" a compostos intermetálicos com alto teor de fósforo, como verificado nas tabela 5.5 a 5.8 .

Igualmente ao verificado por microscopia óptica, a região da interface metal base/ junta brasada apresenta coerência e zonas sem muita diluição.

Diferentemente da condição anterior, aqui não há evidências claras da presença de campos eutéticos nos quatro casos.

Assim como na análise por microscopia óptica, verifica-se que na região próxima a interface nos AID UNS S32750 e UNS S32707 houve decomposição da fase ferrítica, apresentando-se nas figuras 5.32 e 5.33 como regiões claras no contorno do grão austenítico. No AID S32750 este fenômeno não se mostra com nitidez, entretanto o AID UNS S32707 (figura 5.33) deixa bem evidenciada esta região.

Similar a condição anterior a relação $[(\mathrm{Ni}+\mathrm{Cr}) / \mathrm{P}]$ e $(\mathrm{Ni} / \mathrm{P})$ das fases "b" e "c" também permanecem bastante próximas, como constatado nas tabela 5.5 a 5.8.

- UNS S32101

(a)

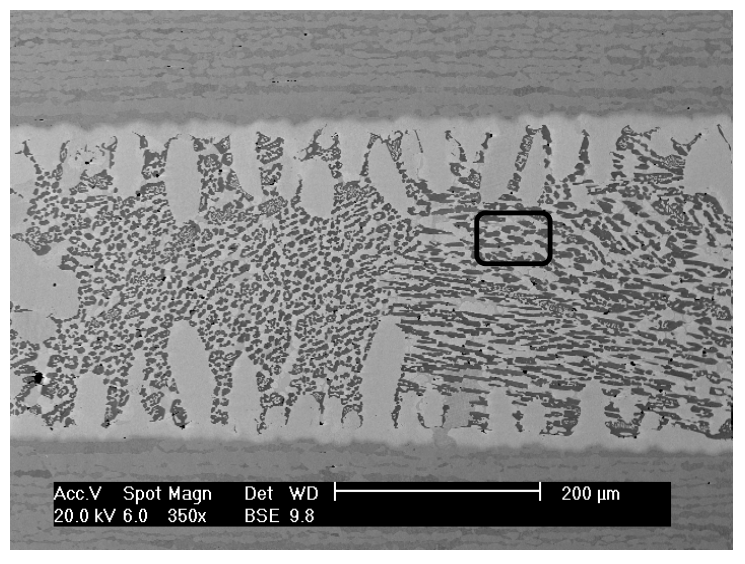

(b)

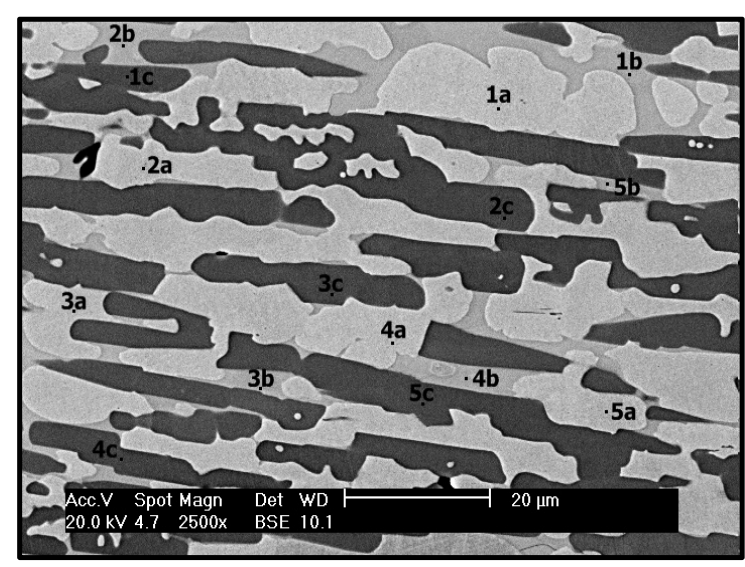

Figura 5.30 - Micrografias por MEV da região da junta brasada do AID UNS S32101. Em a) vista geral e b) ampliação região interna.

Tabela 5.5- Análise química via EDS das fases identificadas na junta brasada do AID UNS S32101.

\begin{tabular}{|c|c|c|c|c|c|c|c|}
\hline \multirow{2}{*}{ Região } & \multicolumn{5}{|c|}{ Composição Química (at.\%) } & \multirow{2}{*}{$\begin{array}{l}\text { Relação } \\
{[(\mathrm{Ni}+\mathrm{Cr}) / \mathrm{P}]}\end{array}$} & \multirow{2}{*}{$\begin{array}{c}\text { Relação } \\
(\mathrm{Ni} / \mathrm{P})\end{array}$} \\
\hline & $\mathrm{Ni}$ & $\mathrm{Fe}$ & $\mathrm{Cr}$ & $P$ & $\mathrm{Si}$ & & \\
\hline a & 63,99 & 23,99 & 9,41 & 1,37 & 1,24 & - & - \\
\hline $\mathrm{b}$ & 57,55 & 9,66 & 8,71 & 22,20 & 1,89 & - & 2,59 \\
\hline C & 28,79 & 8,55 & 29,95 & 30,59 & 2,62 & 1,92 & - \\
\hline
\end{tabular}


- UNS S32304

(a)

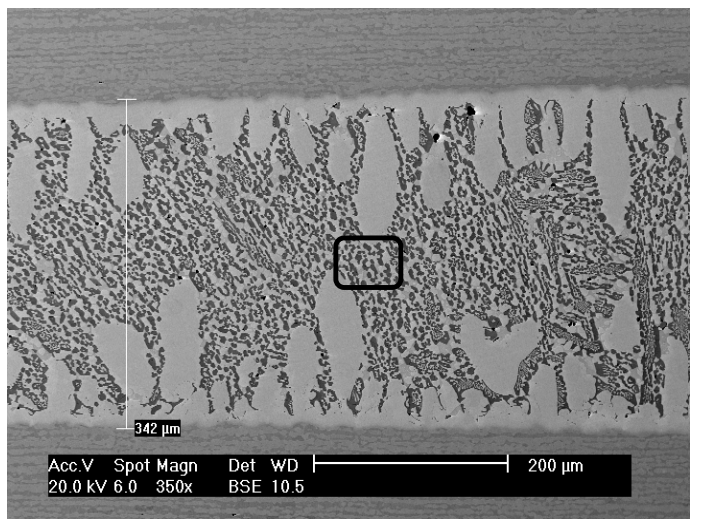

(b)

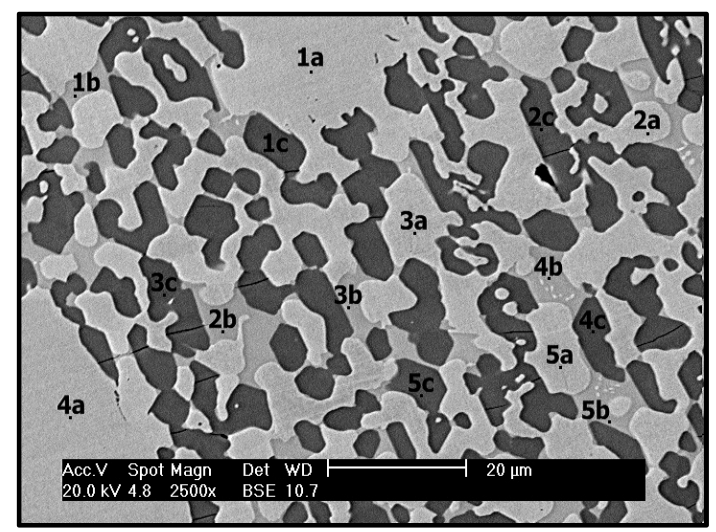

Figura 5.31 - Micrografias por MEV da região da junta brasada do AID UNS S32304. Em a) vista geral e b) ampliação região interna.

Tabela 5.6 - Análise química via EDS das fases identificadas na junta brasada do AID UNS S32101.

\begin{tabular}{|c|c|c|c|c|c|c|c|}
\hline \multirow{2}{*}{ Região } & \multicolumn{5}{|c|}{ Composição Química (at.\%) } & \multirow{2}{*}{$\begin{array}{l}\text { Relação } \\
{[(\mathrm{Ni}+\mathrm{Cr}) / \mathrm{P}]}\end{array}$} & \multirow{2}{*}{$\begin{array}{c}\text { Relação } \\
(\mathrm{Ni} / \mathrm{P})\end{array}$} \\
\hline & $\mathrm{Ni}$ & $\mathrm{Fe}$ & $\mathrm{Cr}$ & $P$ & $\mathrm{Si}$ & & \\
\hline$a$ & 58,35 & 26,22 & 12,59 & 1,60 & 1,24 & - & - \\
\hline $\mathrm{b}$ & 58,25 & 12,08 & 8,31 & 19,85 & 1,51 & - & 2,93 \\
\hline C & 29,15 & 8,55 & 30,37 & 29,82 & 2,11 & 1,99 & - \\
\hline
\end{tabular}

- UNS S32750

(a)

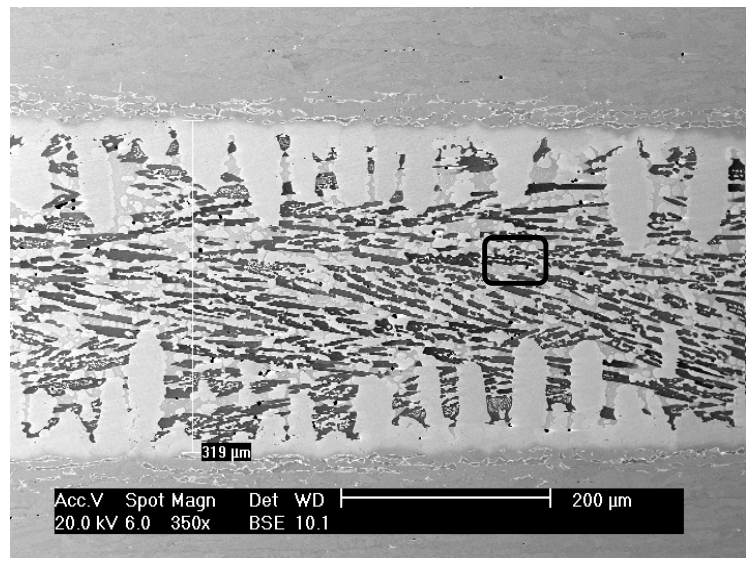

(b)

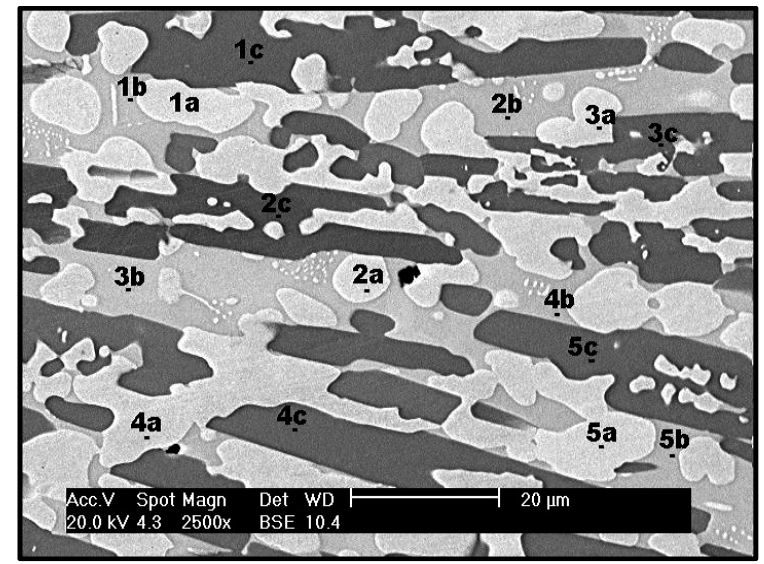

Figura 5.32 - Micrografias por MEV da região da junta brasada do AID UNS S32750. Em a) vista geral e b) ampliação região interna. 
Tabela 5.7 - Análise química via EDS das fases identificadas na junta brasada do AID UNS S32750.

\begin{tabular}{|c|c|c|c|c|c|c|c|}
\hline \multirow{2}{*}{ Região } & \multicolumn{5}{|c|}{ Composição Química (at.\%) } & \multirow{2}{*}{$\begin{array}{l}\text { Relação } \\
{[(\mathrm{Ni}+\mathrm{Cr}) / \mathrm{P}]}\end{array}$} & \multirow{2}{*}{$\begin{array}{l}\text { Relação } \\
(\mathrm{Ni} / \mathrm{P})\end{array}$} \\
\hline & $\mathrm{Ni}$ & $\mathrm{Fe}$ & $\mathrm{Cr}$ & $\mathrm{P}$ & $\mathrm{Si}$ & & \\
\hline a & 68,01 & 18,64 & 11,27 & 1,11 & 0,96 & - & - \\
\hline$b$ & 60,88 & 6,66 & 9,05 & 21,85 & 1,56 & - & 2,78 \\
\hline C & 33,10 & 4,95 & 28,92 & 31,38 & 1,65 & 1,97 & - \\
\hline
\end{tabular}

- UNS S32707

(a)

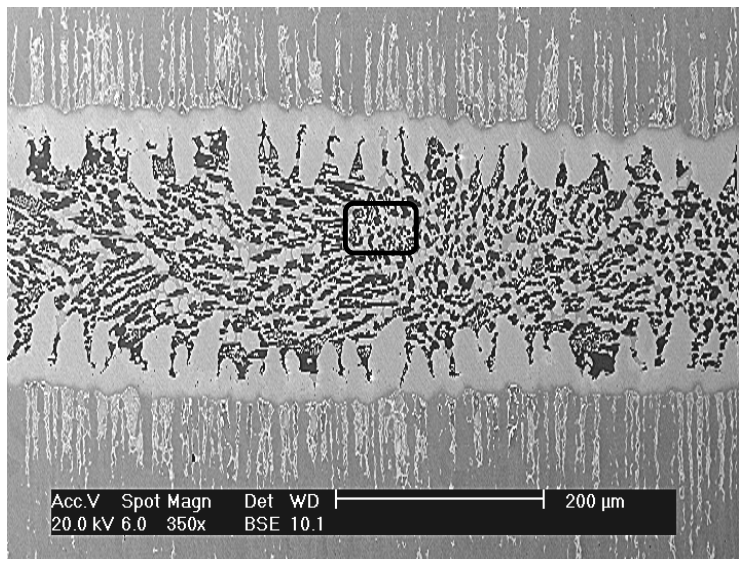

(b)

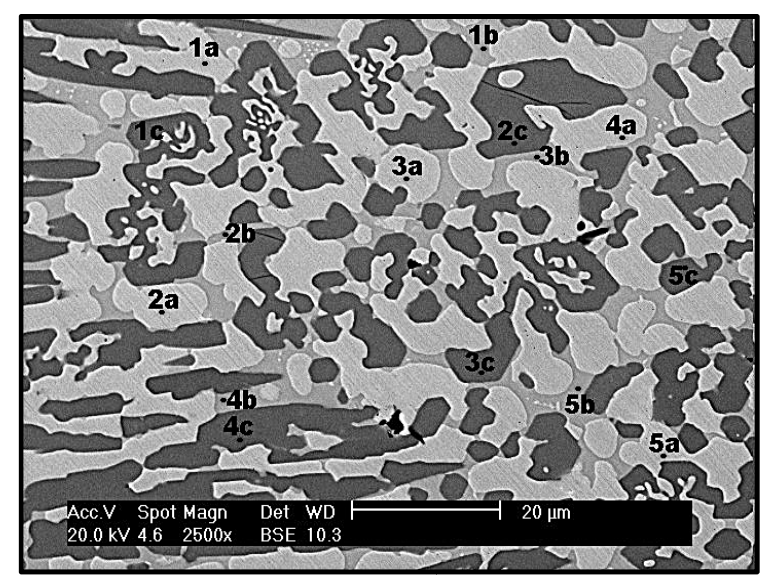

Figura 5.33 - Micrografias por MEV da região da junta brasada do AID UNS S32707. Em a) vista geral e b) ampliação região interna.

Tabela 5.8 - Análise química via EDS das fases identificadas na junta brasada do AID UNS S32707.

\begin{tabular}{|c|c|c|c|c|c|c|c|}
\hline \multirow[t]{2}{*}{ Região } & \multicolumn{5}{|c|}{ Composição Química (at.\%) } & \multirow{2}{*}{$\begin{array}{c}\text { Relação } \\
{[(\mathrm{Ni}+\mathrm{Cr}) / \mathrm{P}]}\end{array}$} & \multirow{2}{*}{$\begin{array}{c}\text { Relação } \\
(\mathrm{Ni} / \mathrm{P})\end{array}$} \\
\hline & $\mathrm{Ni}$ & $\mathrm{Fe}$ & $\mathrm{Cr}$ & $\mathrm{P}$ & $\mathrm{Si}$ & & \\
\hline a & 67,36 & 19,41 & 10,97 & 1,40 & 0,87 & - & - \\
\hline $\mathrm{b}$ & 60,84 & 7,71 & 8,82 & 21,15 & 1,48 & - & 2,88 \\
\hline c & 31,75 & 5,79 & 29,22 & 31,69 & 1,55 & 1,92 & - \\
\hline
\end{tabular}

\subsubsection{Condição 3: tempo de $32 \mathrm{~min}$ e $0,0 \mathrm{~mm}$ de folga}

Mostra-se nas figuras 5.34 a 5.37 a microestrutura da junta brasada dos diferentes AID. Por meio destas imagens, verifica-se a presença de duas fases desenvolvidas na microestrutura da junta brasada no caso dos AID baixa liga UNS S32101 e UNS 
S32304. A primeira, de maior proporção, é identificada como " $A$ " contendo altos teores de ferro e níquel, a segunda fase forma-se na região central da junta apresentando morfologia descontínua, identificada como "B" contendo altos teores de fósforo como pode ser constatado nas tabela 5.9 a 5.12. Diferente das outras condições, a fase "A" apresenta uma diminuição no teor de níquel e aumento no teor de ferro.

No caso do AISD e AIHD vê-se na microestrutura a presença de uma fase a mais das vistas nos AID baixa liga, esta fase, marcada como "C" apresenta teores médios de níquel e cromo quando comparado com as fases "A" e "B"( tabelas 5.11 e 5.12), contudo possui um alto teor de fósforo similar à fase $B$.

- UNS S32101

(a)

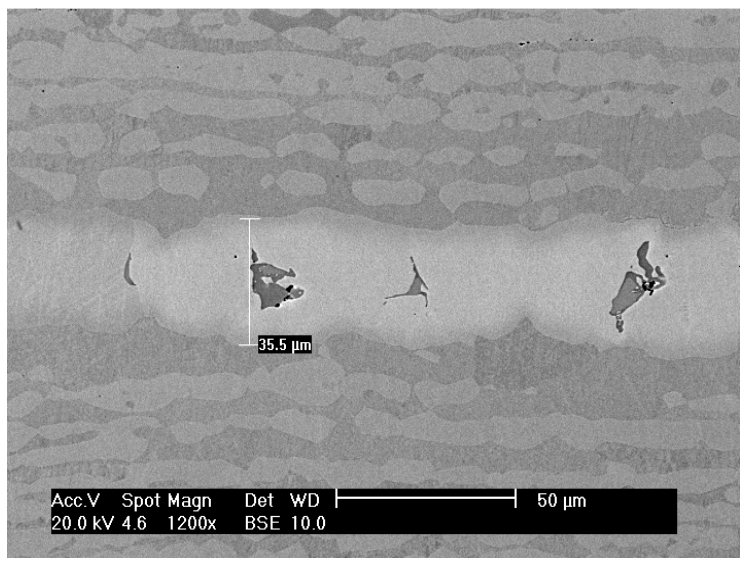

(b)

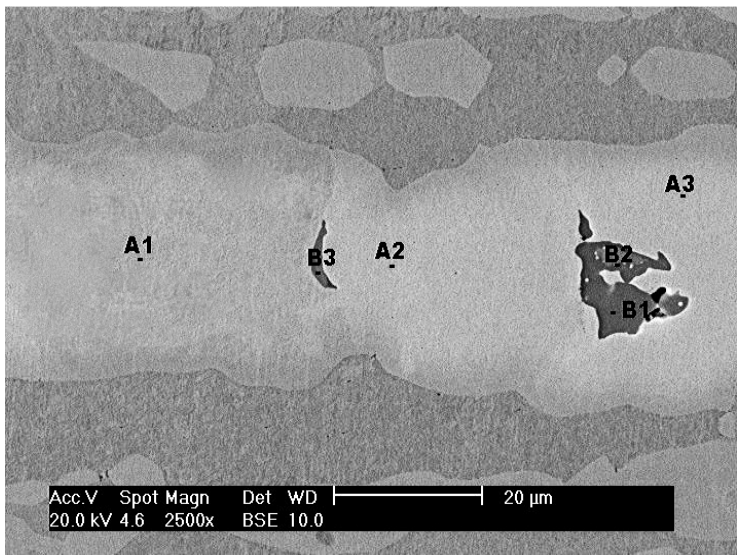

Figura 5.34 - Micrografias por MEV da região da junta brasada do AID UNS S32101. Em a) vista geral e b) ampliação região interna.

Tabela 5.9 - Análise química via EDS das fases identificadas na junta brasada do AID UNS S32101.

\begin{tabular}{ccccccc}
\hline \multirow{2}{*}{ Região } & \multicolumn{5}{c}{ Composição Química (at.\%) } & \multicolumn{2}{c}{ Relação } \\
\cline { 2 - 6 } & $\mathrm{Ni}$ & $\mathrm{Fe}$ & $\mathrm{Cr}$ & $\mathrm{P}$ & $\mathrm{Si}$ & {$[(\mathrm{Ni}+\mathrm{Cr}) / \mathrm{P}]$} \\
\hline $\mathrm{A}$ & 39,83 & 41,04 & 16,71 & 1,11 & 1,31 & - \\
\hline $\mathrm{B}$ & 20,22 & 17,92 & 29,78 & 30,10 & 1,97 & 1,66 \\
\hline
\end{tabular}


- UNS S32304

(a)

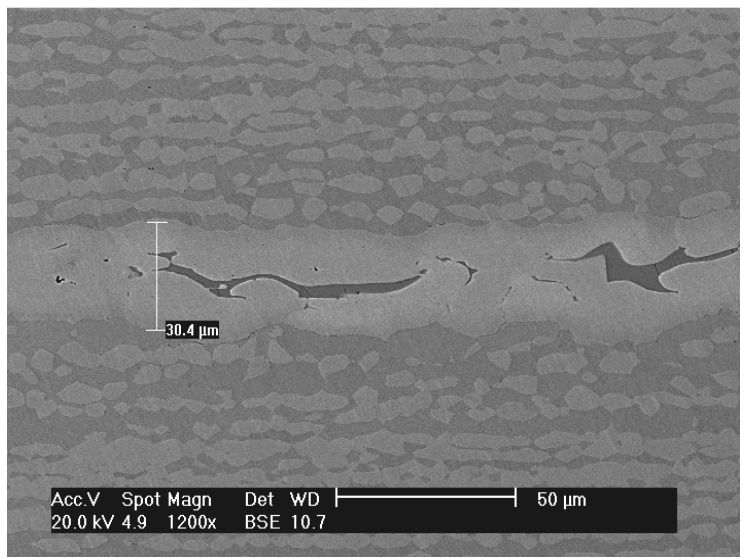

(b)

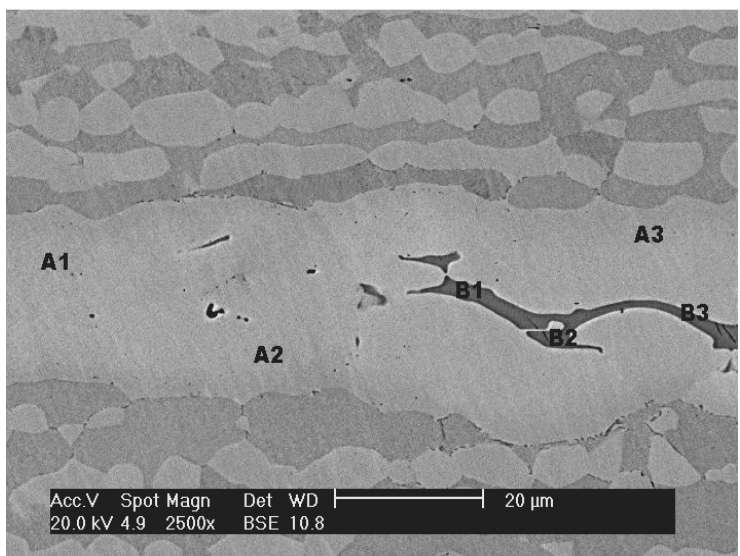

Figura 5.35 - Micrografias por MEV da região da junta brasada do AID UNS S32304. Em a) vista geral e b) ampliação região interna.

Tabela 5.10 - Análise química via EDS das fases identificadas na junta brasada do AID UNS S32101.

\begin{tabular}{ccccccc}
\hline \multirow{2}{*}{ Região } & \multicolumn{4}{c}{ Composição Química (at.\%) } & Relação \\
\cline { 2 - 6 } & $\mathrm{Ni}$ & $\mathrm{Fe}$ & $\mathrm{Cr}$ & $\mathrm{P}$ & $\mathrm{Si}$ & {$[(\mathrm{Ni}+\mathrm{Cr}) / \mathrm{P}]$} \\
\hline $\mathrm{A}$ & 26,83 & 50,51 & 20,26 & 1,21 & 1,19 & - \\
\hline $\mathrm{B}$ & 10,29 & 27,03 & 40,05 & 20,98 & 1,65 & 2,39 \\
\hline
\end{tabular}

- UNS S32750

(a)

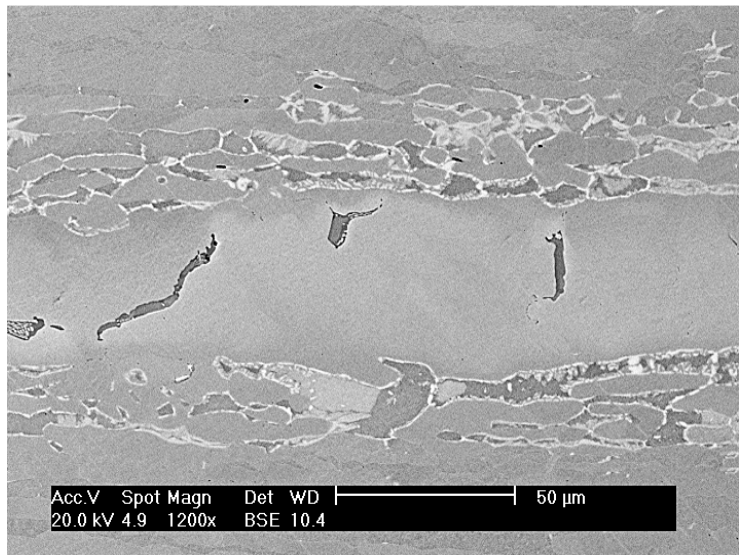

(b)

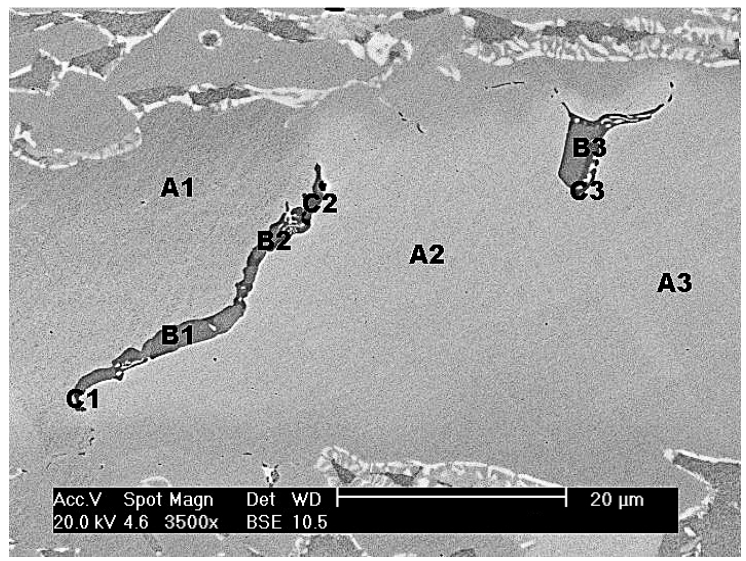

Figura 5.36 - Micrografias por MEV da região da junta brasada do AID UNS S32750. Em a) vista geral e b) ampliação região interna. 
Tabela 5.11- Análise química via EDS das fases identificadas na junta brasada do AID UNS S32750.

\begin{tabular}{|c|c|c|c|c|c|c|c|}
\hline \multirow{2}{*}{ Região } & \multicolumn{6}{|c|}{ Composição Química (at.\%) } & \multirow{2}{*}{$\begin{array}{l}\text { Relação } \\
{[(\mathrm{Ni}+\mathrm{Cr}) / \mathrm{P}]}\end{array}$} \\
\hline & $\mathrm{Ni}$ & $\mathrm{Fe}$ & $\mathrm{Cr}$ & $P$ & $\mathrm{Si}$ & Mo & \\
\hline A & 29,59 & 28,29 & 15,96 & 1,28 & 1,03 & 1,03 & - \\
\hline$B$ & 16,50 & 12,06 & 27,10 & 24,23 & 1,55 & 2,75 & 1,80 \\
\hline C & 26,79 & 20,98 & 25,83 & 22,23 & 1,60 & 2,57 & 2,34 \\
\hline
\end{tabular}

- UNS S32707

(a)

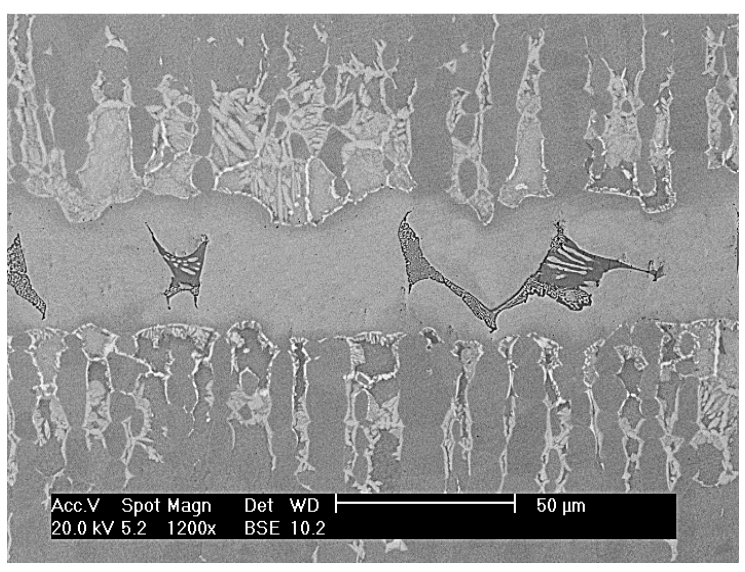

(b)

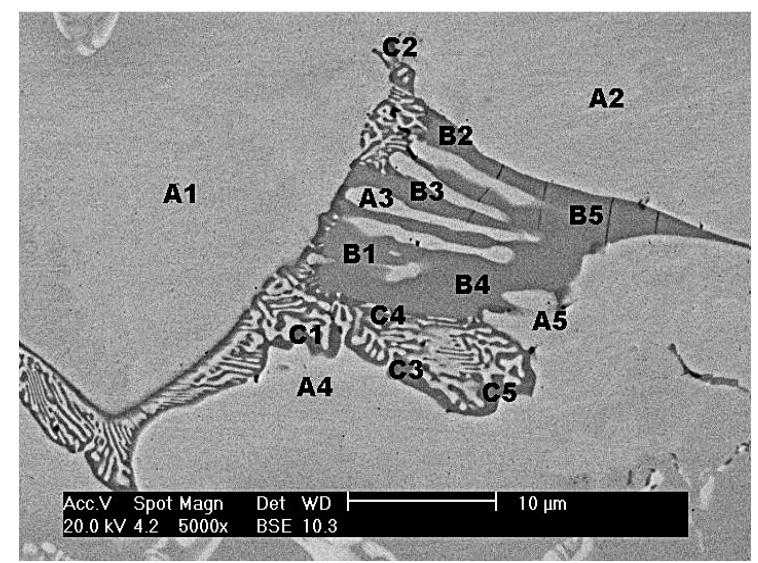

Figura 5.37 - Micrografias por MEV da região da junta brasada do AID UNS S32707. Em a) vista geral e b) ampliação região interna.

Tabela 5.12 - Análise química via EDS das fases identificadas na junta brasada do AID UNS S32707.

\begin{tabular}{cccccccc}
\hline \multirow{2}{*}{ Região } & \multicolumn{8}{c}{ Composição Química (at.\%) } & \multicolumn{2}{c}{ Relação } \\
\cline { 2 - 7 } & $\mathrm{Ni}$ & $\mathrm{Fe}$ & $\mathrm{Cr}$ & $\mathrm{P}$ & $\mathrm{Si}$ & $\mathrm{Mo}$ & {$[(\mathrm{Ni}+\mathrm{Cr}) / \mathrm{P}]$} \\
\hline $\mathrm{A}$ & 30,59 & 27,29 & 15,96 & 1,28 & 0,97 & 1,20 & - \\
\hline $\mathrm{B}$ & 18,50 & 11,05 & 27,10 & 23,24 & 1,55 & 2,65 & 1,90 \\
\hline $\mathrm{C}$ & 26,79 & 19,98 & 26,83 & 22,33 & 1,50 & 2,07 & 2,40 \\
\hline
\end{tabular}

\subsubsection{Condição 4: tempo de $12 \mathrm{~min}$ e $0,5 \mathrm{~mm}$ de folga}

As figuras 5.38 a 5.41 apresentam as imagens obtidas por MEV das regiões brasadas dos quatro AID em estudo. Assim como nas condições de brasagem 1 e 2, na presente condição também são identificadas as três fases que formam a microestrutura da junta, "a", "b" e "c", repetindo-se a identificação feita 
anteriormente. O quadro em cor preta indica a região escolhida para observação com maiores aumentos. Os resultados da analise química nas tabelas 5.13 a 5.16 apresentam similaridade com a analise química da condição 1.

Para esta condição são observadas claramente campos eutéticos, identificados como "E" nas microestruturas das juntas brasadas dos quatro AID.

- UNS S32101

(a)

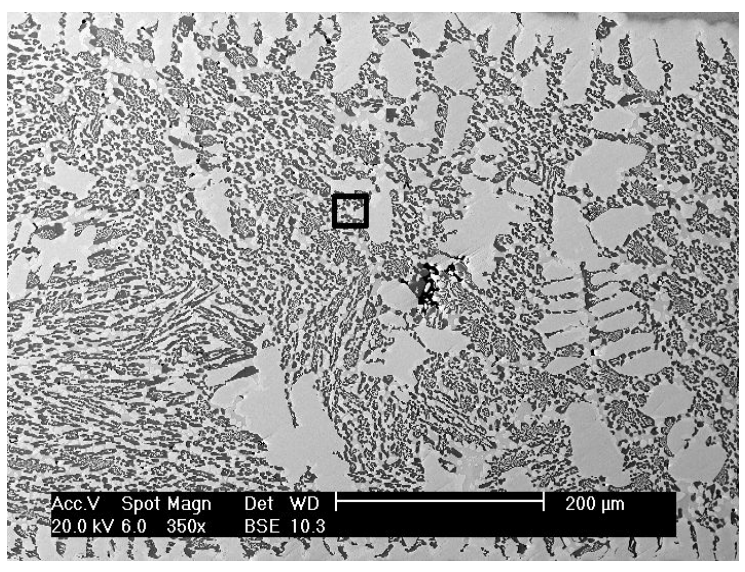

(b)

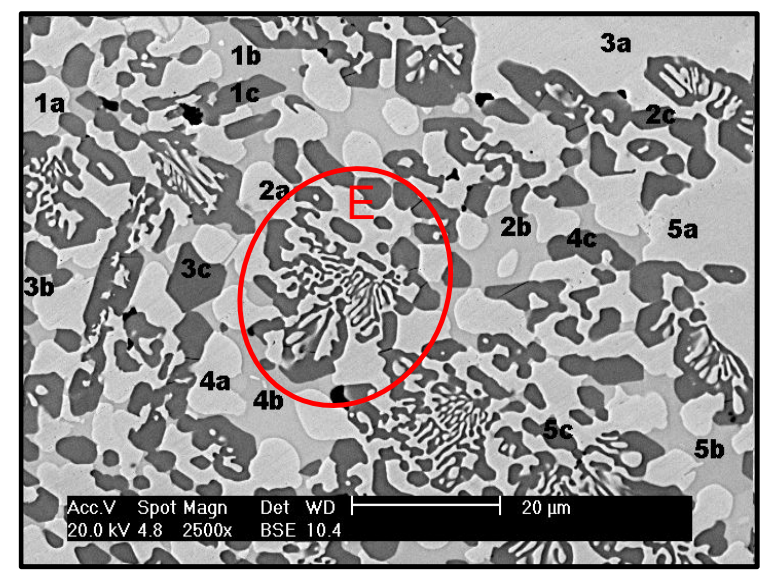

Figura 5.38 - Micrografias por MEV da região da junta brasada do AID UNS S32101. Em a) vista geral e b) ampliação região interna.

Tabela 5.13 - Análise química via EDS das fases identificadas na junta brasada do AID UNS S32101.

\begin{tabular}{cccccccc}
\hline \multirow{2}{*}{ Região } & \multicolumn{6}{c}{ Composição Química (at.\%) } & \multicolumn{2}{c}{ Relação } & Relação \\
\cline { 2 - 6 } & $\mathrm{Ni}$ & $\mathrm{Fe}$ & $\mathrm{Cr}$ & $\mathrm{P}$ & $\mathrm{Si}$ & {$[(\mathrm{Ni}+\mathrm{Cr}) / \mathrm{P}]$} & $(\mathrm{Ni} / \mathrm{P})$ \\
\hline a & 60,00 & 25,84 & 11,38 & 1,48 & 1,30 & - & - \\
\hline $\mathrm{b}$ & 58,91 & 8,76 & 7,25 & 23,24 & 1,84 & - & 2,53 \\
\hline $\mathrm{c}$ & 29,54 & 8,42 & 29,05 & 31,17 & 1,83 & 1,88 & - \\
\hline
\end{tabular}


- UNS S32304

(a)

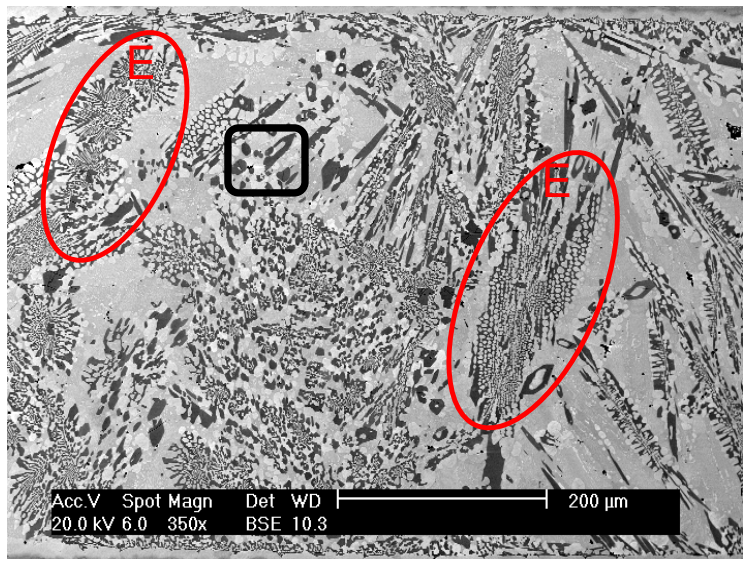

(b)

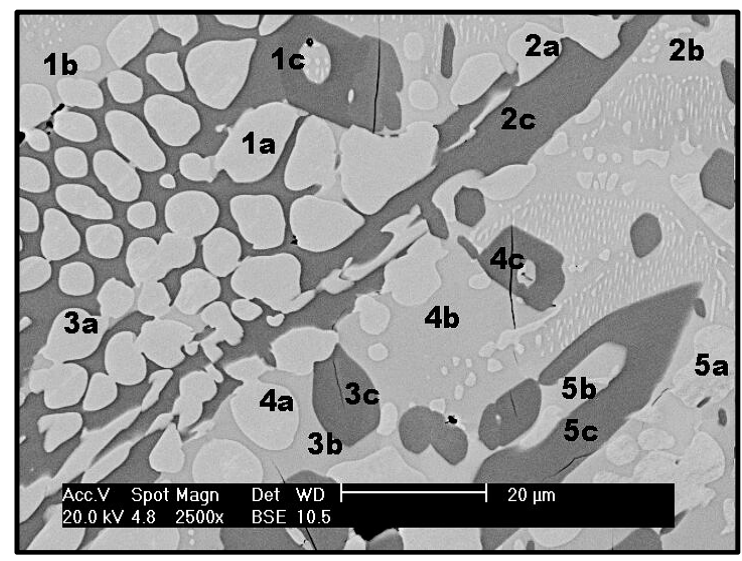

Figura 5.39 - Micrografias por MEV da região da junta brasada do AID UNS S32304. Em a) vista geral e b) ampliação região interna.

Tabela 5.14 - Análise química via EDS das fases identificadas na junta brasada do AID UNS S32304.

\begin{tabular}{|c|c|c|c|c|c|c|c|}
\hline \multirow{2}{*}{ Região } & \multicolumn{5}{|c|}{ Composição Química (at.\%) } & \multirow{2}{*}{$\begin{array}{c}\text { Relação } \\
{[(\mathrm{Ni}+\mathrm{Cr}) / \mathrm{P}]}\end{array}$} & \multirow{2}{*}{$\begin{array}{c}\text { Relação } \\
\text { (Ni/P) }\end{array}$} \\
\hline & $\mathrm{Ni}$ & $\mathrm{Fe}$ & $\mathrm{Cr}$ & $\mathrm{P}$ & $\mathrm{Si}$ & & \\
\hline a & 64,80 & 22,11 & 10,72 & 1,48 & 0,89 & & - \\
\hline b & 58,53 & 7,23 & 9,51 & 23,09 & 1,64 & - & 2,53 \\
\hline $\mathrm{c}$ & 31,36 & 6,10 & 28,77 & 31,88 & 1,89 & 1,89 & - \\
\hline
\end{tabular}

- UNS S32750

(a)

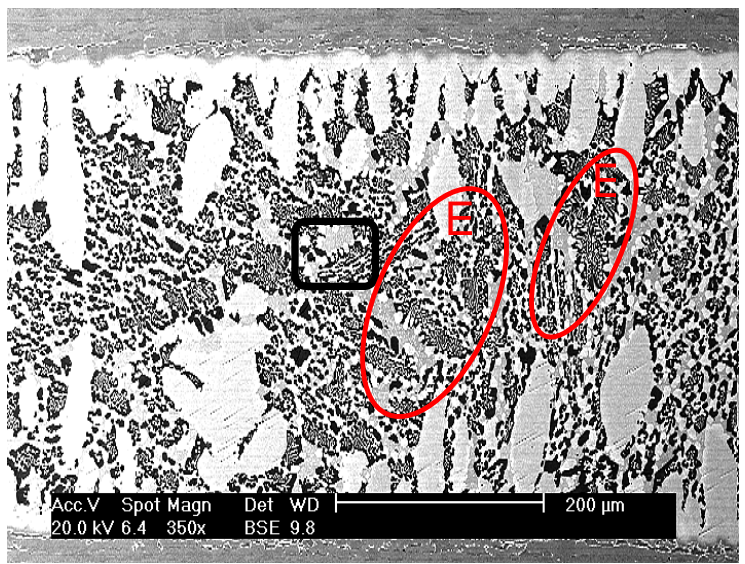

(b)

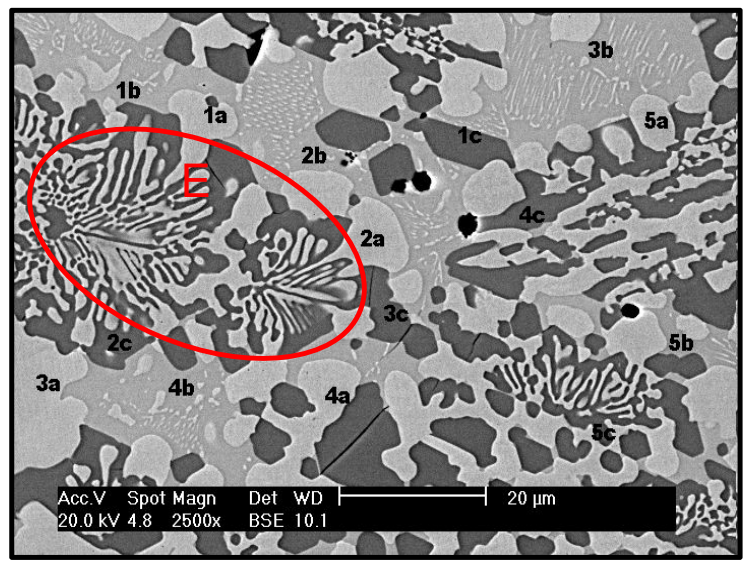

Figura 5.40 - Micrografias por MEV da região da junta brasada do AID UNS S32750. Em a) vista geral e b) ampliação região interna. 
Tabela 5.15 - Análise química via EDS das fases identificadas na junta brasada do AID UNS S32750.

\begin{tabular}{|c|c|c|c|c|c|c|c|}
\hline \multirow{2}{*}{ Região } & \multicolumn{5}{|c|}{ Composição Química (at.\%) } & \multirow{2}{*}{$\begin{array}{c}\text { Relação } \\
{[(\mathrm{Ni}+\mathrm{Cr}) / \mathrm{P}]}\end{array}$} & \multirow{2}{*}{$\begin{array}{c}\text { Relação } \\
(\mathrm{Ni} / \mathrm{P})\end{array}$} \\
\hline & $\mathrm{Ni}$ & $\mathrm{Fe}$ & $\mathrm{Cr}$ & $\mathrm{P}$ & $\mathrm{Si}$ & & \\
\hline $\mathrm{a}$ & 66,21 & 19,43 & 12,16 & 1,39 & 0,81 & - & - \\
\hline$b$ & 60,73 & 6,32 & 8,82 & 22,44 & 1,68 & - & 2,71 \\
\hline C & 32,96 & 5,77 & 29,30 & 30,48 & 1,49 & 2,04 & - \\
\hline
\end{tabular}

- UNS S32707

(a)

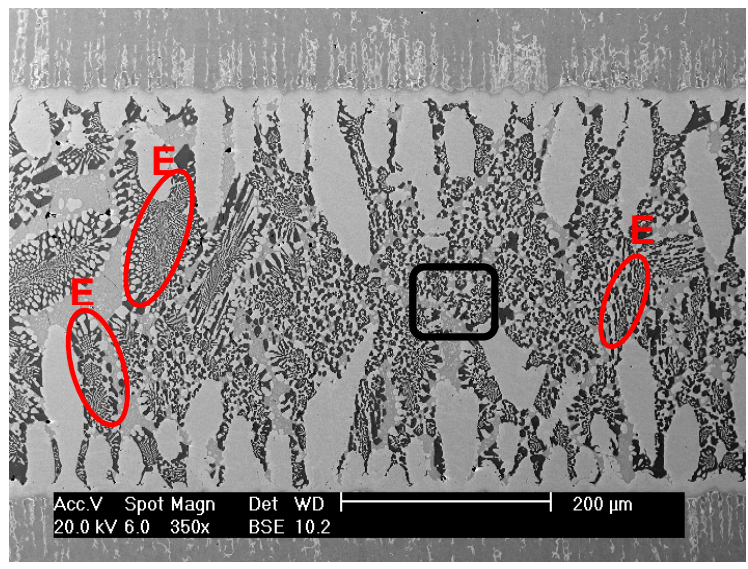

(b)

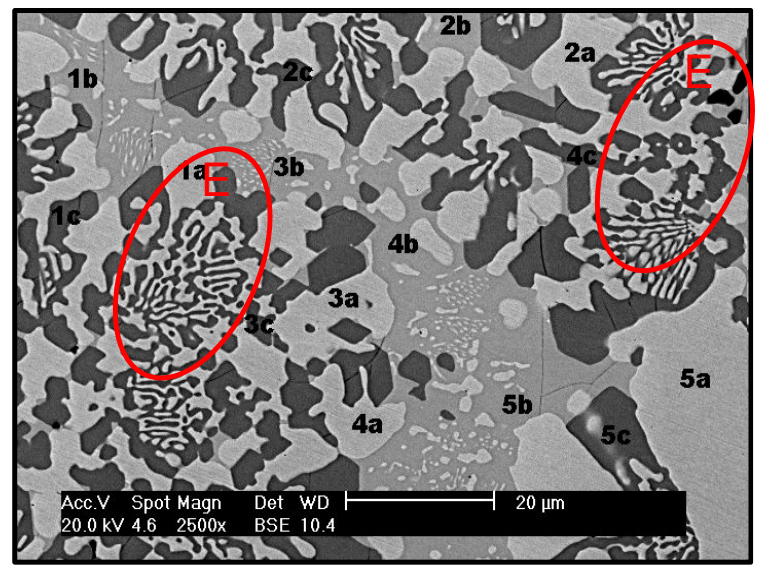

Figura 5.41 - Micrografias por MEV da região da junta brasada do AID UNS S32707. Em a) vista geral e b) ampliação região interna.

Tabela 5.16 - Análise química via EDS das fases identificadas na junta brasada do AID UNS S32707.

\begin{tabular}{|c|c|c|c|c|c|c|c|c|}
\hline \multirow[b]{2}{*}{ Região } & \multicolumn{6}{|c|}{ Composição Química (at.\%) } & \multirow{2}{*}{$\begin{array}{c}\text { Relação } \\
{[(\mathrm{Ni}+\mathrm{Cr}) / \mathrm{P}]}\end{array}$} & \multirow{2}{*}{$\begin{array}{c}\text { Relação } \\
(\mathrm{Ni} / \mathrm{P})\end{array}$} \\
\hline & $\mathrm{Ni}$ & $\mathrm{Fe}$ & $\mathrm{Cr}$ & $\mathrm{P}$ & $\mathrm{Si}$ & Mo & & \\
\hline a & 68,17 & 19,26 & $\overline{11,62}$ & 0,84 & 0,53 & $\overline{0,40}$ & - & - \\
\hline b & 61,73 & 4,32 & 9,82 & 22,44 & 1,68 & & - & 2,75 \\
\hline c & 31,66 & 5,77 & 30,30 & 30,48 & 1,49 & 1,28 & 2.03 & \\
\hline
\end{tabular}




\subsubsection{Condição 5: tempo de $12 \mathrm{~min}$ e $0,3 \mathrm{~mm}$ de folga}

As micrografias para esta condição são apresentadas nas figuras 5.42 a 5.45 . Do mesmo modo que nas condições de brasagem 1, 2 e 4, a microestrutura da junta está formada pelas três fases previamente identificadas, sendo estas as fases "a", "b" e "c". A composição química das fases que compõem a junta brasada dos quatro AID, esta apresentada nas tabela 5.17 a 5.20. De igual forma que na condição anterior a diminuição do tempo de brasagem exerce grande influencia na microestrutura final da junta, encontrando-se claramente campos eutéticos, os quais estão identificados como "E" nas microestruturas das juntas brasadas dos quatro AID.

- UNS S32101

(a)

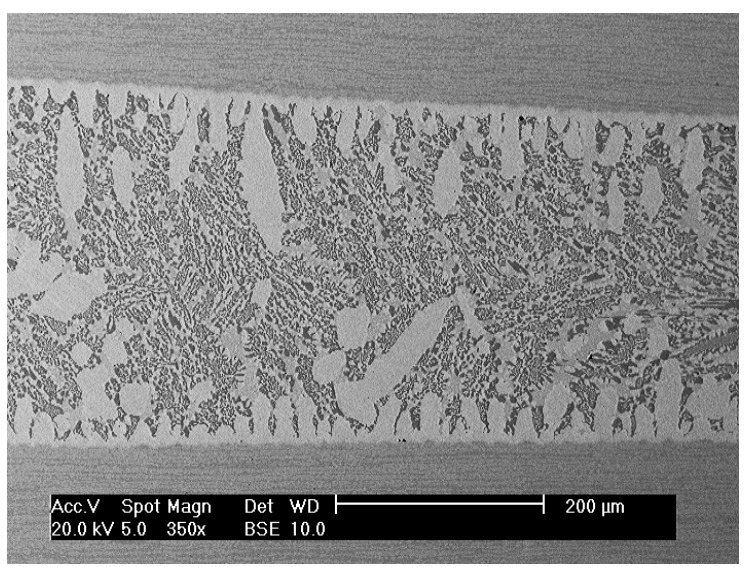

(b)

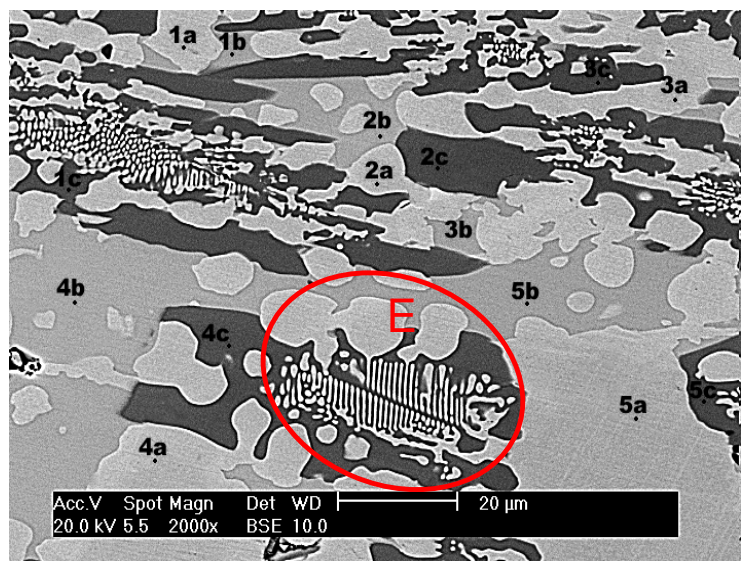

Figura 5.42 - Micrografias por MEV da região da junta brasada do AID UNS S32101. Em a) vista geral e b) ampliação região interna.

Tabela 5.17 - Análise química via EDS das fases identificadas na junta brasada do AID UNS S32101.

\begin{tabular}{|c|c|c|c|c|c|c|c|}
\hline \multirow{2}{*}{ Região } & \multicolumn{5}{|c|}{ Composição Química (at.\%) } & \multirow{2}{*}{$\begin{array}{l}\text { Relação } \\
{[(\mathrm{Ni}+\mathrm{Cr}) / \mathrm{P}]}\end{array}$} & \multirow{2}{*}{$\begin{array}{c}\text { Relação } \\
(\mathrm{Ni} / \mathrm{P})\end{array}$} \\
\hline & $\mathrm{Ni}$ & $\mathrm{Fe}$ & $\mathrm{Cr}$ & $\mathrm{P}$ & Si & & \\
\hline a & 57,96 & 27,05 & 13,31 & 1,46 & 0,22 & - & - \\
\hline$b$ & 58,84 & 8,35 & 7,48 & 24,98 & 0,35 & - & 2,36 \\
\hline$C$ & 30,28 & 8,02 & 29,37 & 32,15 & 0,18 & 1,86 & - \\
\hline
\end{tabular}


- UNS S32304

(a)

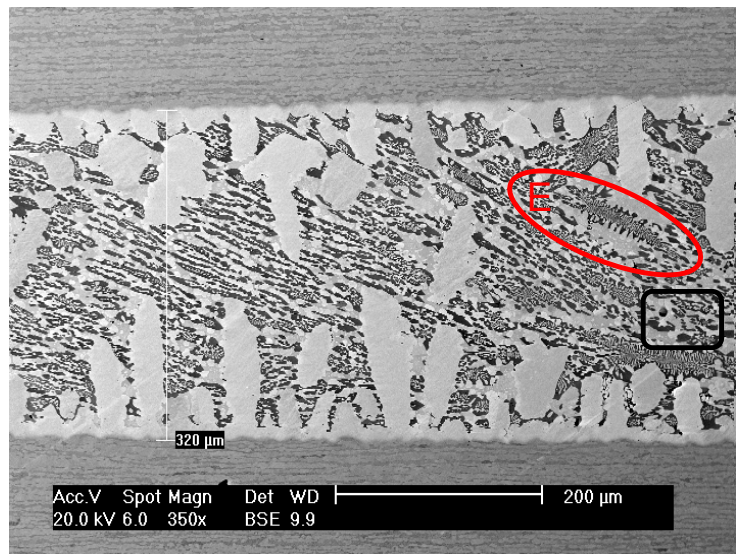

(b)

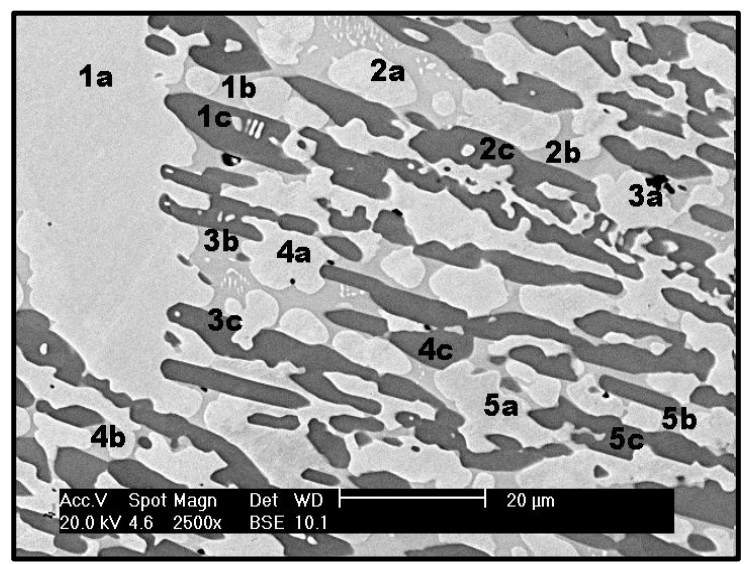

Figura 5.43 - Micrografias por MEV da região da junta brasada do AID UNS S32304. Em a) vista geral e b) ampliação região interna.

Tabela 5.18 - Análise química via EDS das fases identificadas na junta brasada do AID UNS S32304.

\begin{tabular}{cccccccc}
\hline \multirow{2}{*}{ Região } & \multicolumn{9}{c}{ Composição Química (at.\%) } & Relação & Relação \\
\cline { 2 - 6 } & $\mathrm{Ni}$ & $\mathrm{Fe}$ & $\mathrm{Cr}$ & $\mathrm{P}$ & $\mathrm{Si}$ & {$[(\mathrm{Ni}+\mathrm{Cr}) / \mathrm{P}]$} & $(\mathrm{Ni} / \mathrm{P})$ \\
\hline $\mathrm{a}$ & 60,56 & 24,30 & 12,81 & 1,42 & 0,92 & - & - \\
\hline $\mathrm{b}$ & 58,18 & 8,67 & 8,39 & 23,07 & 1,69 & - & 2,52 \\
\hline $\mathrm{c}$ & 29,75 & 7,27 & 29,44 & 31,77 & 1,77 & 1,86 & - \\
\hline
\end{tabular}

- UNS S32750

(a)

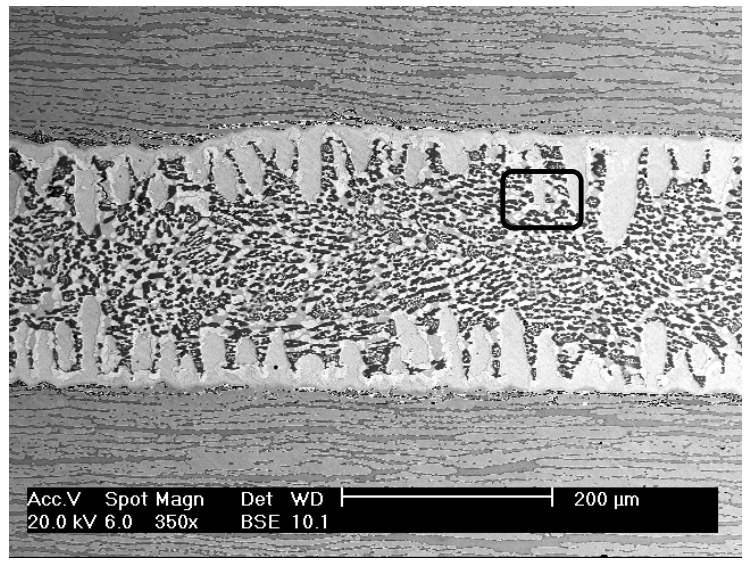

(b)

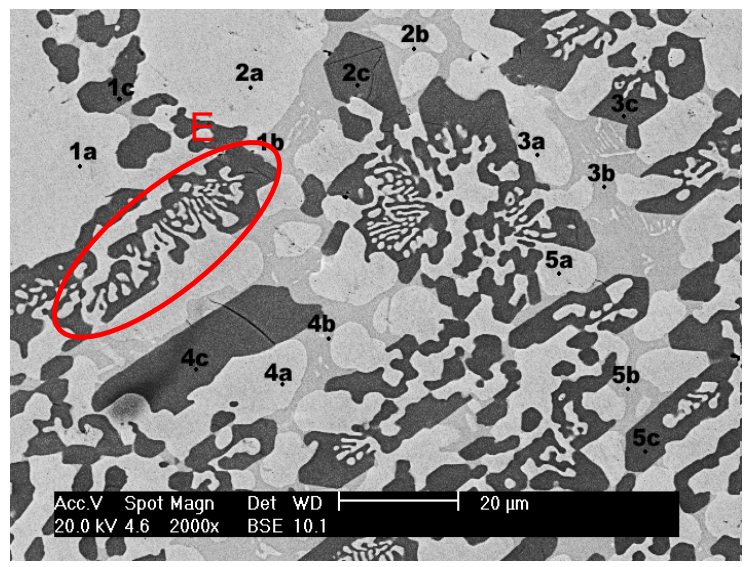

Figura 5.44 - Micrografias por MEV da região da junta brasada do AID UNS S32750. Em a) vista geral e b) ampliação região interna. 
Tabela 5.19 - Análise química via EDS das fases identificadas na junta brasada do AID UNS S32750.

\begin{tabular}{cccccccc}
\hline \multirow{2}{*}{ Região } & \multicolumn{9}{c}{ Composição Química (at.\%) } & $\begin{array}{c}\text { Relação } \\
{[}\end{array}$ & $\mathrm{Ni}$ & $\mathrm{Fe}$ & $\mathrm{Cr}$ & $\mathrm{P}$ & $\mathrm{Si}$ & $\begin{array}{c}\text { Relação } \\
\text { [(Ni+Cr)/P] }\end{array}$ & \begin{tabular}{c} 
(Ni/P) \\
\hline a
\end{tabular} & 60,56 & 24,30 & 12,81 & 1,42 & 0,92 & - & - \\
\hline b & 58,18 & 8,67 & 8,39 & 23,07 & 1,69 & - & 2,52 \\
\hline c & 29,75 & 7,27 & 29,44 & 31,77 & 1,77 & 1,86 & - \\
\hline
\end{tabular}

UNS S32707

(a)

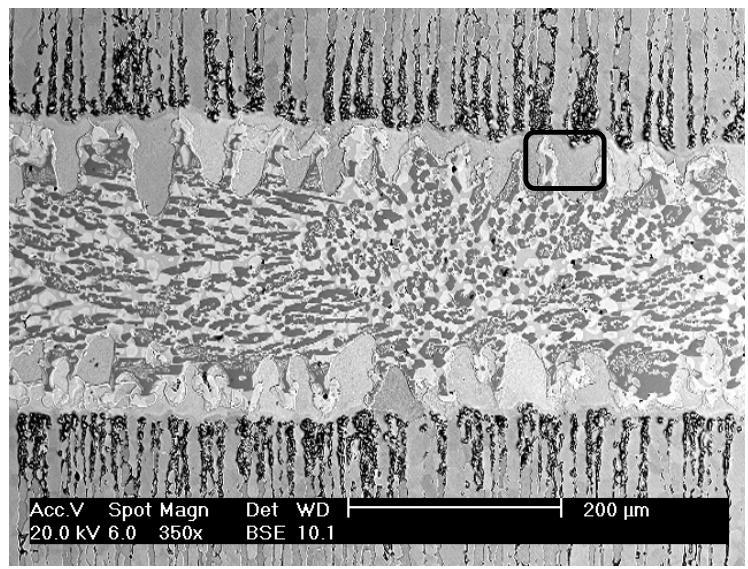

(b)

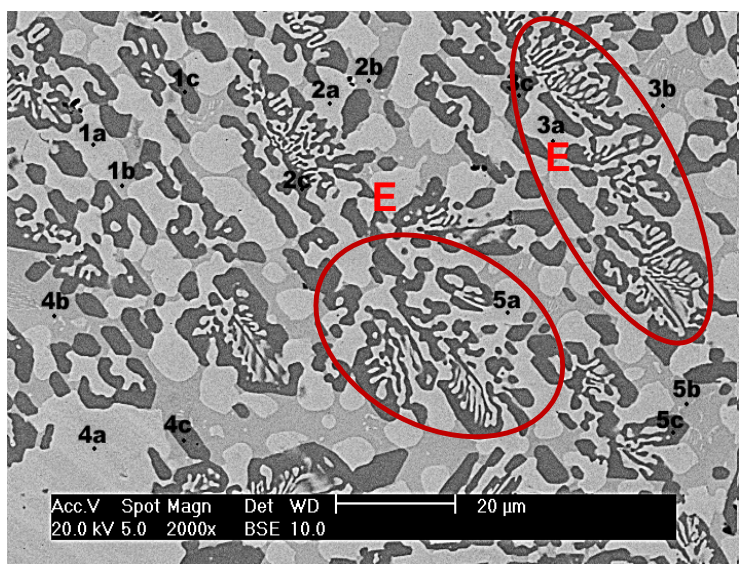

Figura 5.45 - Micrografias por MEV da região da junta brasada do AID UNS S32707. Em a) vista geral e b) ampliação região interna.

Tabela 5.20 - Análise química via EDS das fases identificadas na junta brasada do AID UNS S32707.

\begin{tabular}{cccccccc}
\hline \multirow{2}{*}{ Região } & \multicolumn{6}{c}{ Composição Química (at.\%) } & \multirow{2}{\text{Relação}}{ Relação } \\
\cline { 2 - 6 } & $\mathrm{Ni}$ & $\mathrm{Fe}$ & $\mathrm{Cr}$ & $\mathrm{P}$ & $\mathrm{Si}$ & $\begin{array}{c}\text { Rel } \\
\text { (Ni+Cr)/P] }\end{array}$ & (Ni/P) \\
\hline a & 60,56 & 24,30 & 12,81 & 1,42 & 0,92 & - & - \\
\hline b & 58,18 & 8,67 & 8,39 & 23,07 & 1,69 & - & 2,52 \\
\hline c & 29,75 & 7,27 & 29,44 & 31,77 & 1,77 & 1,86 & - \\
\hline
\end{tabular}

\subsubsection{Condição 6: tempo de $12 \mathrm{~min}$ e $0,0 \mathrm{~mm}$ de folga}

As micrografias 5.46 a 5.49 mostram a microestrutura da junta brasada para os quatro AID. Diferente da microestrutura bifásica observada na condição 3 , nesta condição, a junta apresentou uma microestrutura composta por três fases. A fase clara massiva "A" , a intermediaria com tonalidade cinzenta "B" e fase escura " $C$ ". 
Apesar da diminuição da folga são observadas fases eutéticas compostos pelas fases "A" e "C" formados na região central da junta para os aços

- UNS S32101

(a)

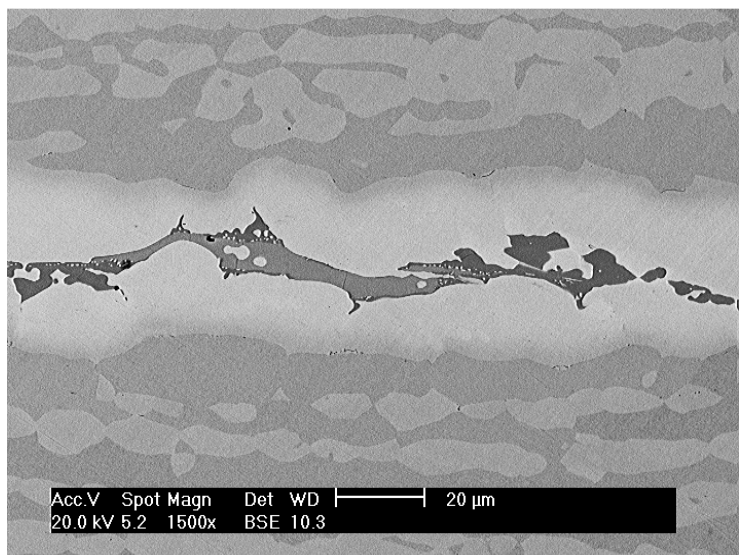

(b)

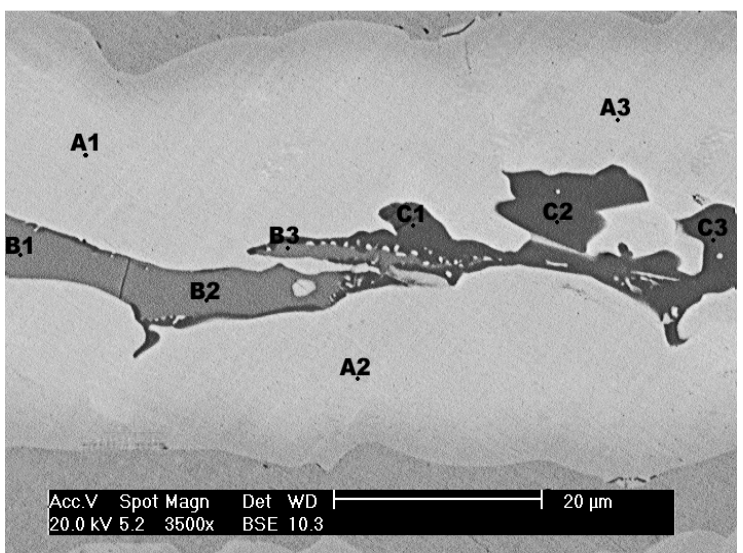

Figura 5.46 - Micrografias por MEV da região da junta brasada do AID UNS S32101. Em a) vista geral e b) ampliação região interna.

Tabela 5.21- Análise química via EDS das fases identificadas na junta brasada do AID UNS S32101.

\begin{tabular}{|c|c|c|c|c|c|c|}
\hline \multirow{2}{*}{ Região } & \multicolumn{5}{|c|}{ Composição Química (at.\%) } & \multirow{2}{*}{$\begin{array}{r}\text { Relaçãao } \\
{[(\mathrm{Ni}+\mathrm{Cr}) / \mathrm{P}]}\end{array}$} \\
\hline & $\mathrm{Ni}$ & $\mathrm{Fe}$ & $\mathrm{Cr}$ & $\mathrm{P}$ & $\mathrm{Si}$ & \\
\hline A & 40.66 & 40.35 & 16.73 & 1.83 & 0.43 & - \\
\hline & & & 34.99 & 24. & & \\
\hline C & 21,80 & 15.08 & 29.57 & 33.30 & 0.26 & 1,54 \\
\hline
\end{tabular}

- UNS S32304

(a)

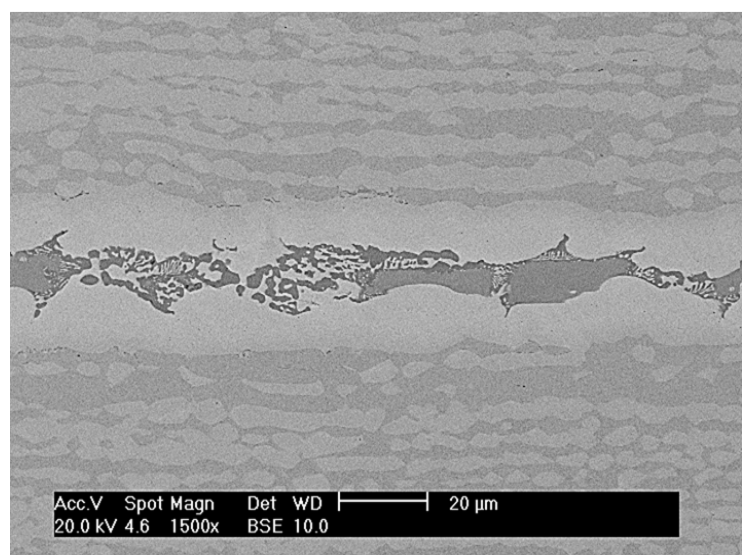

Figura 5.47 - Micrografias por MEV da região da junta brasada do AID UNS S32304. Em a) vista geral e b) ampliação região interna. (b)

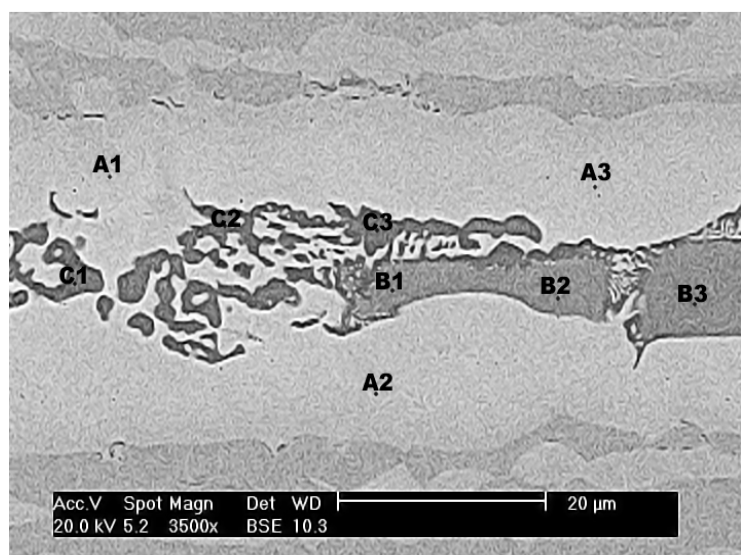


Tabela 5.22- Análise química via EDS das fases identificadas na junta brasada do AID UNS S32304.

\begin{tabular}{ccccccc}
\hline \multirow{2}{*}{ Região } & \multicolumn{3}{c}{ Composição Química (at.\%) } & \multicolumn{2}{c}{ Relação } \\
\cline { 2 - 6 } & $\mathrm{Ni}$ & $\mathrm{Fe}$ & $\mathrm{Cr}$ & $\mathrm{P}$ & $\mathrm{Si}$ & {$[(\mathrm{Ni}+\mathrm{Cr}) / \mathrm{P}]$} \\
\hline $\mathrm{A}$ & 40,27 & 40,72 & 17,23 & 1,47 & 0,31 & - \\
\hline $\mathrm{B}$ & 15,48 & 22,31 & 37,07 & 24,65 & 0,49 & 2,13 \\
\hline $\mathrm{C}$ & 21,69 & 16,53 & 29,51 & 31,44 & 0,83 & 1,63 \\
\hline
\end{tabular}

- UNS S32750

(a)

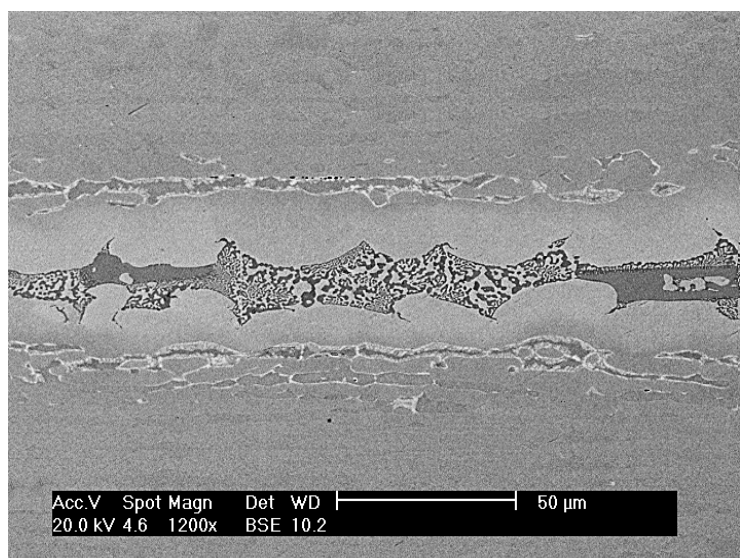

Figura 5.48 - Micrografias por MEV da região da junta brasada do AID UNS S32750. Em a) vista geral e b) ampliação região interna. (b)

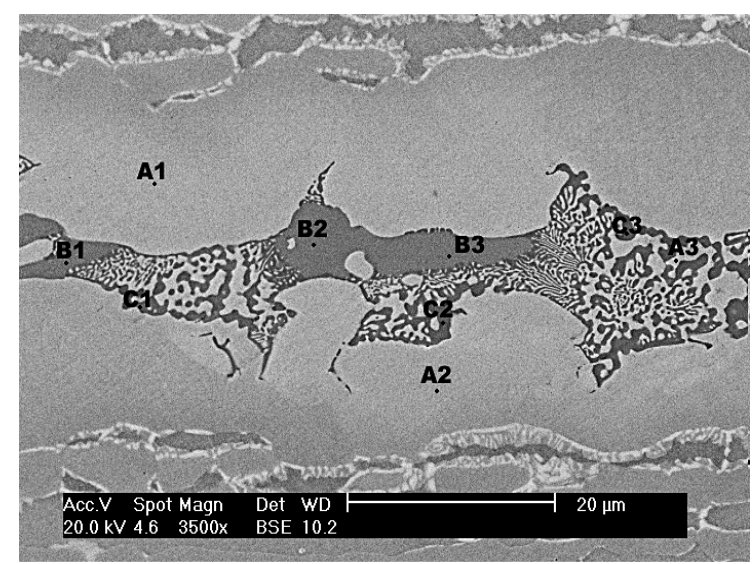

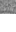


- UNS S32707

(a)

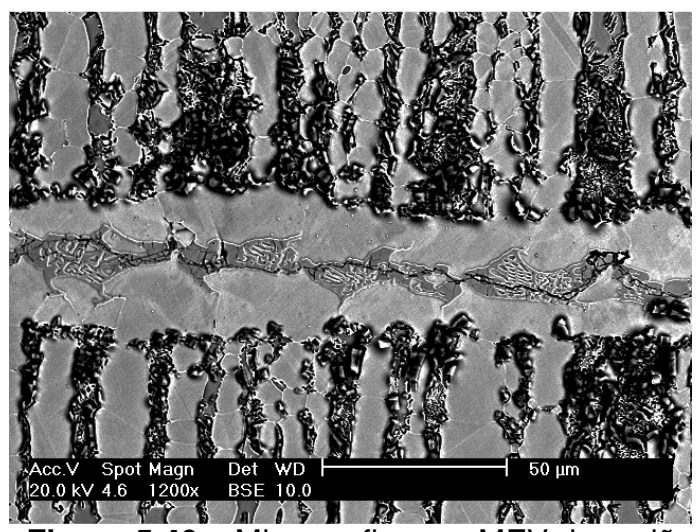

(b)

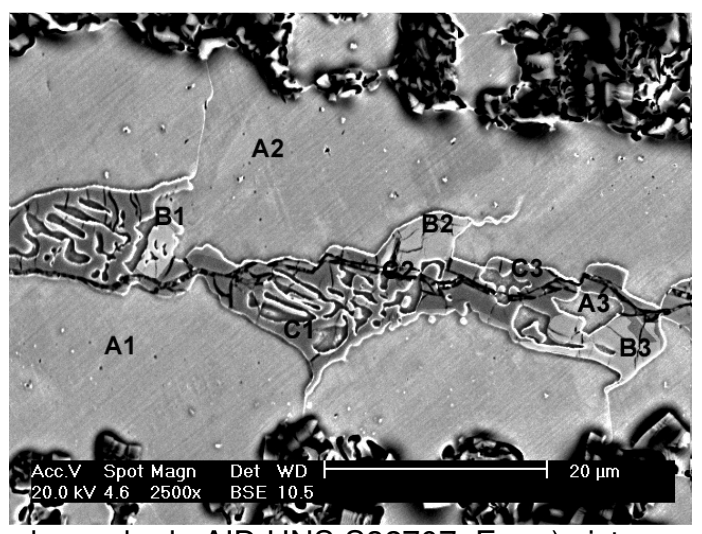

ta brasada do AID UNS S32707. Em a) vista e geral e b) ampliação região interna.

Tabela 5.24 - Análise química via EDS das fases identificadas na junta brasada do AID UNS S32707.

\begin{tabular}{|c|c|c|c|c|c|c|c|}
\hline \multirow{2}{*}{ Região } & \multicolumn{6}{|c|}{ Composição Química (at.\%) } & \multirow{2}{*}{$\begin{array}{c}\text { Relação } \\
{[(\mathrm{Ni}+\mathrm{Cr}) / \mathrm{P}]}\end{array}$} \\
\hline & $\mathrm{Ni}$ & $\mathrm{Fe}$ & $\mathrm{Cr}$ & $P$ & $\mathrm{Si}$ & Mo & \\
\hline$A$ & 41,32 & 35,45 & 19,43 & 1,59 & 1,19 & 1,02 & - \\
\hline $\mathrm{B}$ & 17,45 & 18,14 & 36,62 & 23,37 & 1,49 & 2,93 & 2,31 \\
\hline $\mathrm{C}$ & 24,95 & 15,53 & 27,48 & 26,73 & 1,76 & 3,55 & 1,96 \\
\hline
\end{tabular}




\subsubsection{Caracterização microestrutural da junta brasada por difração de raios $X$}

Inicialmente foi realizado um procedimento de pré-análise dos dados obtidos por difração de raios $X$ na junta brasada dos quatro diferentes AID's. A analise foi realizada com suporte do programa X'Pert High Score Plus. Este programa permitiu uma pré-identificação de fases associadas para cada pico do difratograma como apresentado na figura 5.50. A partir desta pré-análise foi realizada a indexação dos dados obtidos. Os resultados estão apresentados nas tabelas 5.25 a 5.28 , seguidos dos respectivos difratogramas, os quais são mostrados todos os picos considerados na indexação para cada material, como observados nas figuras 5.51 a 5.54. Optouse por mostrar os resultados em forma de tabela devido à grande quantidade de picos do difratograma.

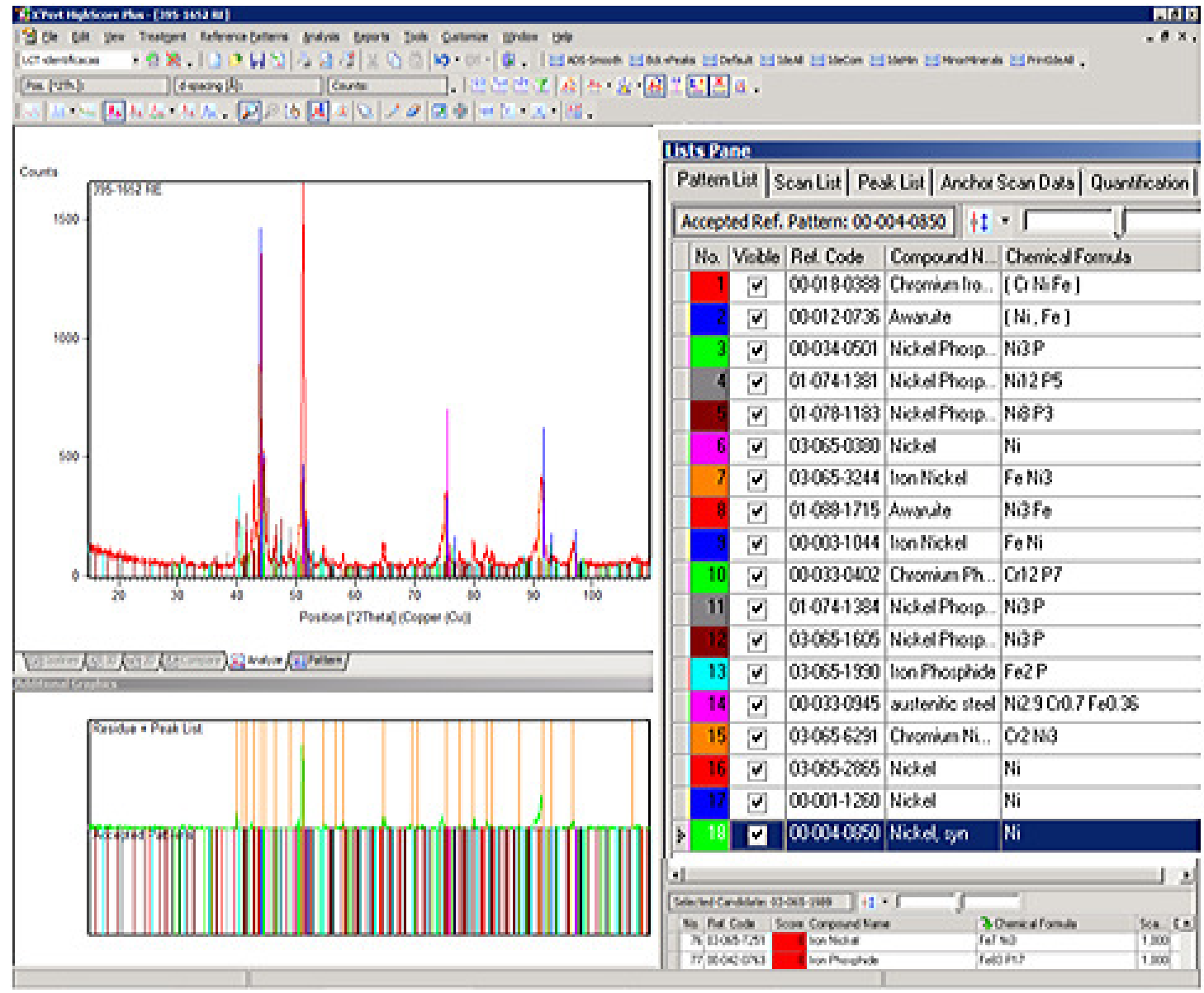

Figura 5.50 - Identificação de fases na junta brasada com suporte do programa X'Pert High Score Plus. 
Tabela 5.25 - Identificação das fases presentes na junta brasada do AID UNS S32101.

\begin{tabular}{|c|c|c|c|c|c|c|c|}
\hline \multirow{2}{*}{ № Picos } & \multirow{2}{*}{$2 \theta$} & \multirow{2}{*}{$d$} & \multirow{2}{*}{$\%$} & \multicolumn{4}{|c|}{ Identificação das fases } \\
\hline & & & & $\mathrm{Ni}_{2} \mathrm{P}$ & $\mathrm{Ni}_{5} \mathrm{P}_{2}$ & $\mathrm{Cr}_{12} \mathrm{P}_{7}$ & $\mathrm{Y}-\mathrm{Ni}$ \\
\hline 1 & 26,2769 & 3,3916 & 6,15 & (001) & & & \\
\hline 2 & 39,9732 & 2,2555 & 6,89 & & & $(2 \overline{2} 0)$ & \\
\hline 3 & 40,9041 & 2,2063 & 13,3 & $(111)$ & & $(211)$ & \\
\hline 4 & 41,5316 & 2,1744 & 9,55 & & (420) & (310) & \\
\hline 5 & 42,8787 & 2,1091 & 27,2 & & (408) & & \\
\hline 6 & 43,9782 & 2,0589 & 71,5 & & & (301) & (111) \\
\hline 7 & 45,0969 & 2,0104 & 21,1 & $(021)$ & & & \\
\hline 8 & 46,4285 & 1,9558 & 12,6 & & (2 2 10) & & \\
\hline 9 & 47,7087 & 1,9063 & 7,34 & $(210)$ & $(600)$ & & \\
\hline 10 & 48,9538 & 1,8607 & 36,7 & & & (221) & \\
\hline 11 & 51,1335 & 1,7863 & 100 & & & & (200) \\
\hline 12 & 51,8967 & 1,7619 & 7,78 & & (610) & & \\
\hline 13 & 54,0131 & 1,6977 & 6,52 & $(300)$ & & $(140)$ & \\
\hline 14 & 54,6181 & 1,6803 & 4,48 & $(002)$ & & & \\
\hline 15 & 56,4612 & 1,6298 & 9,57 & (211) & $(608)$ & $(002)$ & \\
\hline 16 & 70,5694 & 1,3346 & 7,85 & & & (222) & \\
\hline 17 & 75,3334 & 1,2616 & 13,97 & (212) & (556) & & (220) \\
\hline 18 & 90,1686 & 1,0886 & 4,88 & (312) & & & \\
\hline 19 & 91,4870 & 1,0764 & 13,38 & & & & (311) \\
\hline 20 & 107,099 & 0,9576 & 6,54 & (232) & & & \\
\hline
\end{tabular}

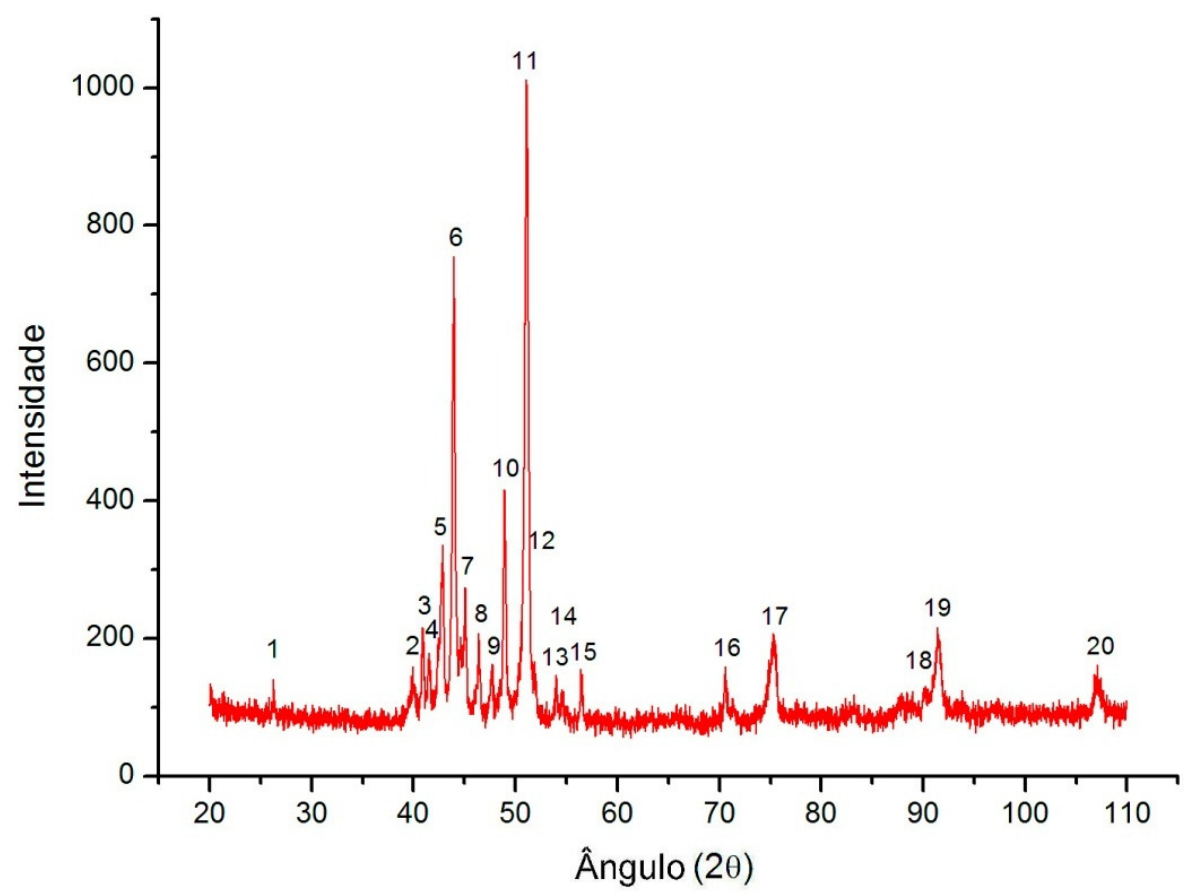

Figura 5.51 - Difratograma da junta brasada do AID UNS S32101. 
Tabela 5.26 - Identificação das fases presentes na junta brasada do AID UNS S32304.

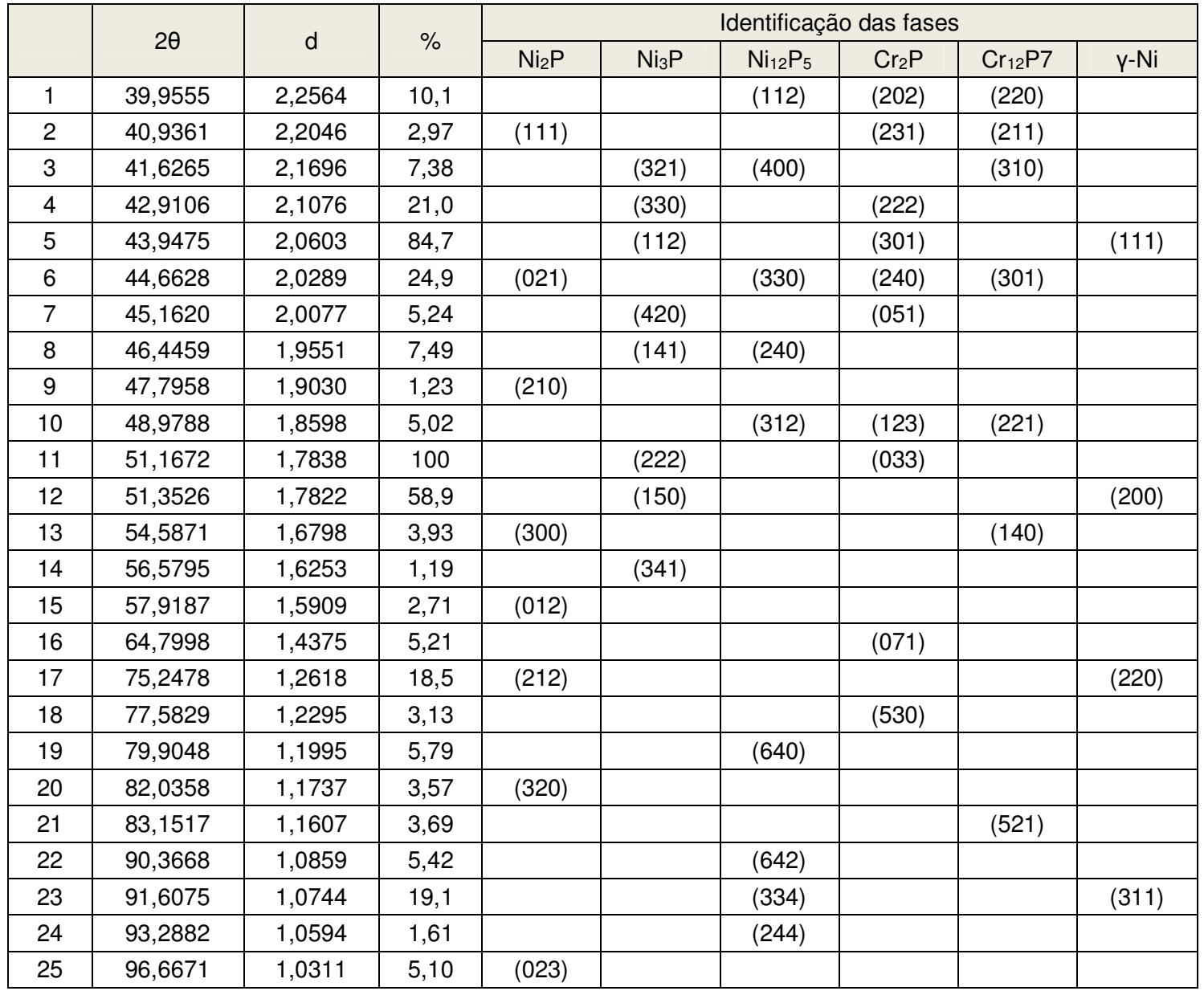

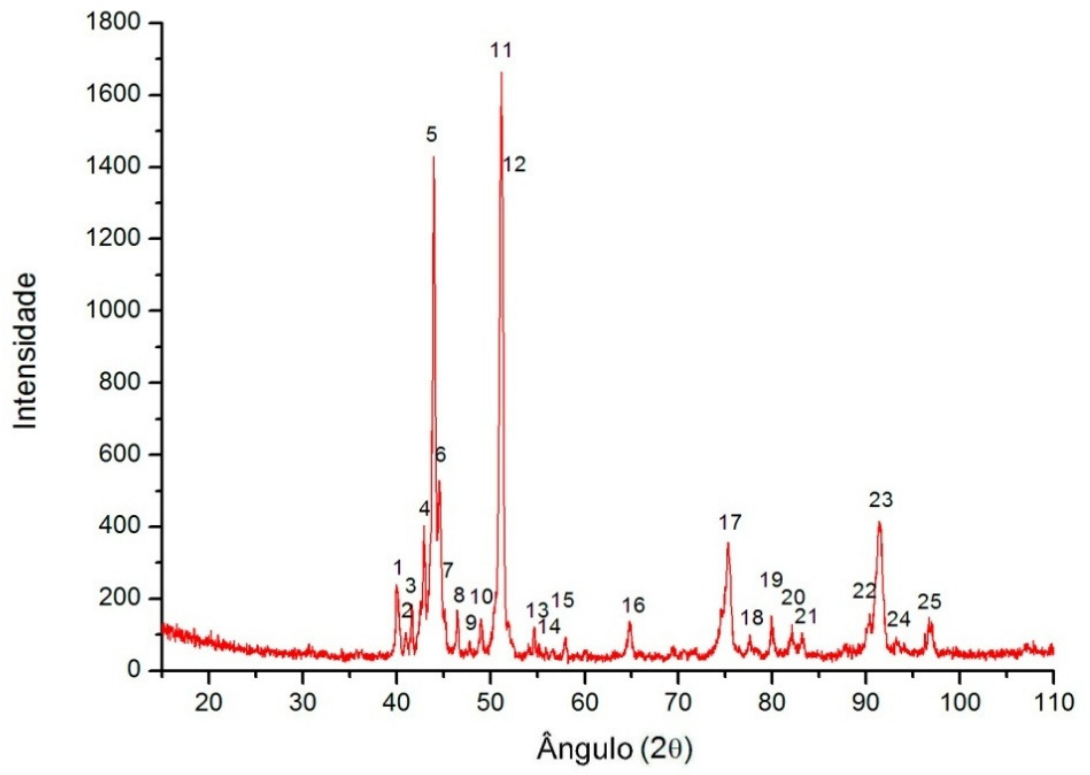

Figura 5.52 - Difratograma da junta brasada do AID UNS S32304. 
Tabela 5.27 - Identificação das fases presentes na junta brasada do AID UNS S32750.

\begin{tabular}{|c|c|c|c|c|c|c|c|c|}
\hline & \multirow{2}{*}{$2 \theta$} & \multirow{2}{*}{ d } & \multirow{2}{*}{$\%$} & \multicolumn{5}{|c|}{ Identificação das fases } \\
\hline & & & & $\mathrm{Ni}_{3} \mathrm{P}$ & $\mathrm{Ni}_{12} \mathrm{P}_{5}$ & $\mathrm{Cr}_{3} \mathrm{P}$ & $\mathrm{Cr}_{1.2} \mathrm{~N}_{\mathrm{i} 0.8} \mathrm{P}$ & $\mathrm{y}-\mathrm{Ni}$ \\
\hline 1 & 39,9958 & 2,25430 & 12,87 & & & $(321)$ & $(210)$ & \\
\hline 2 & 41,6619 & 2,16792 & 24,94 & (321) & (231) & (330); (112) & & \\
\hline 3 & 42,4956 & 2,12554 & 25,49 & & $(400)$ & & & \\
\hline 4 & 42,7811 & 2,11201 & 24,00 & $(330)$ & & & & \\
\hline 5 & 42,8819 & 2,10728 & 28,16 & & & & $(103)$ & \\
\hline 6 & 44,0586 & 2,05539 & 45,09 & $(112)$ & $(330)$ & $(420)$ & & (111) \\
\hline 7 & 45,1915 & 2,00647 & 33,41 & $(420)$ & & $(141)$ & & \\
\hline 8 & 46,4494 & 1,95340 & 17,67 & $(141) ; 202)$ & $(240)$ & & & \\
\hline 9 & 47,7030 & 1,90652 & 10,74 & & & & $(013)$ & \\
\hline 10 & 49,0039 & 1,85892 & 3,69 & & (312) & (222) & (301) & \\
\hline 11 & 51,3218 & 1,77880 & 100 & (222) & & (312) & & \\
\hline 12 & 51,4422 & 1,77639 & 99,28 & & & & & (200) \\
\hline 13 & 51,9800 & 1,75927 & 9,84 & (150) & & & $(020)$ & \\
\hline 14 & 55,1878 & 1,66299 & 9,53 & (341) & & & & \\
\hline 15 & 75,0470 & 1,26468 & 15,67 & (323) & $(352)$ & & & \\
\hline 16 & 75,6378 & 1,25730 & 14,59 & (532) & & $(143)$ & $(015)$ & (220) \\
\hline 17 & 79,8199 & 1,20062 & 4,84 & & $(640)$ & & (314) & \\
\hline 18 & 80,9150 & 1,18711 & 3,20 & (262) & & & & \\
\hline 19 & 87,6503 & 1,11333 & 5,15 & & & $(462)$ & & \\
\hline 20 & 90,4604 & 1,08502 & 7,93 & & (642) & & & \\
\hline 21 & 90,7385 & 1,08510 & 5,54 & & (651) & & & \\
\hline 22 & 91,7937 & 1,07271 & 5,45 & & (334) & & & (311) \\
\hline
\end{tabular}

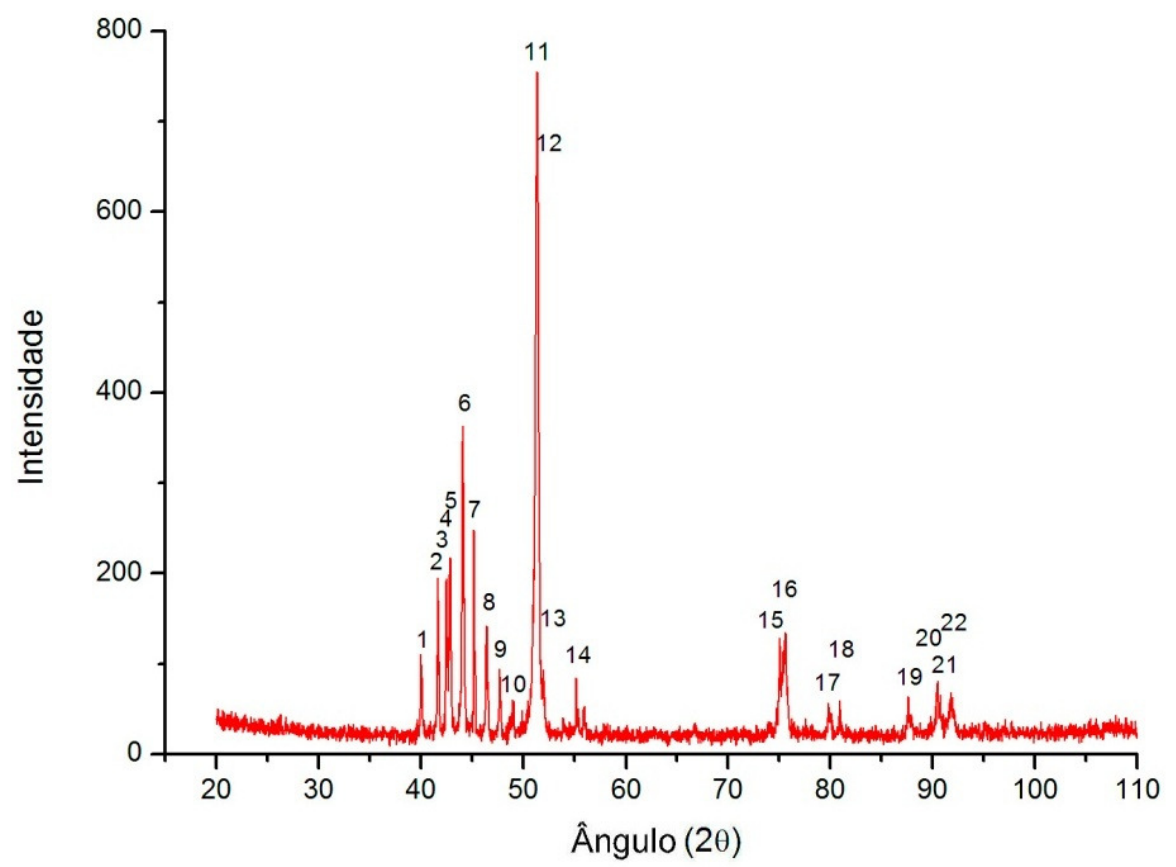

Figura 5.53 - Difratograma da junta brasada do AID UNS S32750. 
Tabela 5.28 - Identificação das fases presentes na junta brasada do AID UNS S32707.

\begin{tabular}{|c|c|c|c|c|c|c|c|c|c|c|}
\hline & \multirow{2}{*}{$2 \theta$} & \multirow{2}{*}{$\mathrm{d}$} & $\%$ & \multicolumn{6}{|c|}{ Identificação das fases } \\
\hline & & & & $\mathrm{Ni}_{2} \mathrm{P}$ & $\mathrm{Ni}_{3} \mathrm{P}$ & $\mathrm{Ni}_{5} \mathrm{P}_{2}$ & $\mathrm{Cr}_{3} \mathrm{P}$ & $\mathrm{Cr}_{12} \mathrm{P}_{7}$ & $\mathrm{Cr}_{1.2} \mathrm{Ni}_{0.8} \mathrm{P}$ & $\mathrm{V}-\mathrm{Ni}$ \\
\hline 1 & 39,9032 & 2,25932 & 4,03 & & & & & $(220)$ & $(210)$ & \\
\hline 2 & 40,7180 & 2,21596 & 13,91 & $(111)$ & & & $(321)$ & & $(202)$ & \\
\hline 3 & 41,6335 & 2,16933 & 13,46 & & $(321)$ & $(420)$ & $(330)$ & $(211)$ & & \\
\hline 4 & 42,4365 & 2,13012 & 9,93 & & & $(422)$ & $(112)$ & & & \\
\hline 5 & 42,8585 & 2,10837 & 71,88 & & $(330)$ & $(229)$ & & & $(103)$ & \\
\hline 6 & 44,0784 & 2,05281 & 77,79 & $(021)$ & $(112)$ & $(424)$ & $(420)$ & $(301)$ & & $(111)$ \\
\hline 7 & 45,2149 & 2,00382 & 9,25 & & $(420)$ & $(506)$ & $(141)$ & & & \\
\hline 8 & 46,4736 & 1,95244 & 15,85 & & $(141)$ & $(3110)$ & & & & \\
\hline 9 & 47,6446 & 1,90715 & 5,86 & $(210)$ & & $(600)$ & & & $(013)$ & \\
\hline 10 & 51,3153 & 1,77901 & 100 & & $(222)$ & $(428)$ & $(312)$ & & & $(200)$ \\
\hline 11 & 51,9976 & 1,75726 & 8,61 & & $(150)$ & & & & $(020)$ & \\
\hline 12 & 53,9388 & 1,69851 & 12,45 & $(300)$ & & & $(431)$ & $(140)$ & $(302)$ & \\
\hline 13 & 54,4526 & 1,68369 & 18,29 & $(002)$ & & & & $(401)$ & $(004)$ & \\
\hline 14 & 60,1347 & 1,53747 & 2,19 & & & $(446)$ & $(422)$ & & & \\
\hline 15 & 62,9645 & 1,47501 & 3,20 & & & & & & $(400)$ & \\
\hline 16 & 65,8202 & 1,41776 & 1,76 & & $(620)$ & & & & & \\
\hline 17 & 71,1384 & 1,32425 & 6,22 & & & & & $(312)$ & & \\
\hline 18 & 74,7325 & 1,26922 & 5,22 & $(212)$ & & & $(602)$ & & & \\
\hline 19 & 75,5044 & 1,25815 & 5,06 & & $(532)$ & $(556)$ & $(143)$ & & & $(220)$ \\
\hline 20 & 77,5034 & 1,23062 & 5,10 & & $(701)$ & & & & & \\
\hline 21 & 88,3643 & 1,10526 & 2,69 & $(321)$ & & & & & & \\
\hline 22 & 90,3883 & 1,08569 & 1,98 & $(013)$ & & & & & & \\
\hline 23 & 91,7746 & 1,07288 & 13,71 & $(312)$ & & & & & & $(311)$ \\
\hline 24 & 93,7783 & 1,05516 & 2,47 & $(141)$ & & & & & & \\
\hline 25 & 97,1601 & 1,02723 & 1,49 & $(023)$ & & & & & & $(222)$ \\
\hline
\end{tabular}

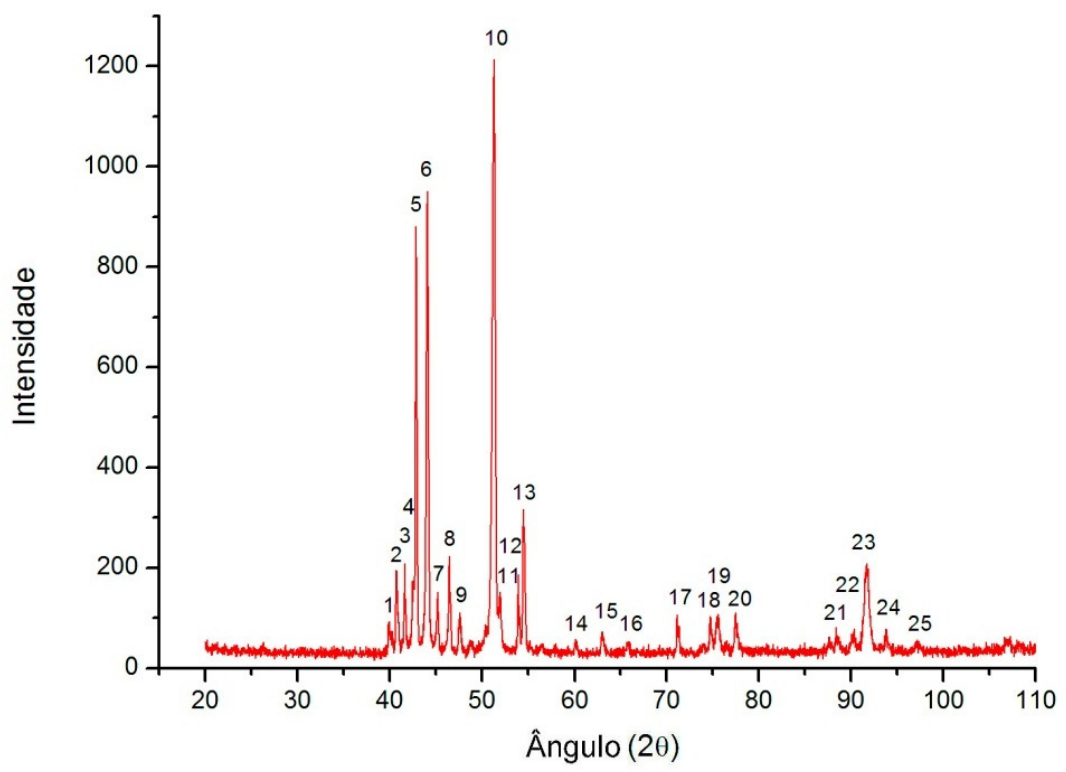

Figura 5.54 - Difratograma da junta brasada do AID UNS S32707. 
Os dados apresentados nas tabela 5.25 a 5.28 foram utilizados para calcular os parâmetros de rede das fases identificadas na junta brasada dos materiais analisados, segundo a metodologia proposta por Cullity [70]. Seguidamente, esses valores foram comparados com os das fichas JCDPS, tal como apresentado nas tabela 5.29 a 5.32 .

Tabela 5.29 - Comparativo entre o parâmetro de rede das fases presentes na junta brasada do AID UNS S32101 e o parâmetro de rede das fichas JCPDS.

\begin{tabular}{|c|c|c|c|}
\hline \multicolumn{2}{|c|}{ UNS32101 } & \multicolumn{2}{|c|}{ Fichas JCPDS } \\
\hline \multicolumn{4}{|c|}{$\mathrm{Ni}_{2} \mathrm{P}(\mathrm{Hex})$} \\
\hline a & C & a & C \\
\hline 5.786 & 3.374 & 5.862 & 3.372 \\
\hline \multicolumn{4}{|c|}{$\mathrm{Ni}_{5} \mathrm{P}_{2}(\mathrm{Hex})$} \\
\hline a & C & a & C \\
\hline 13.305 & 24.627 & 13.22 & 24.63 \\
\hline \multicolumn{4}{|c|}{$\mathrm{Cr}_{12} \mathrm{P}_{7}(\mathrm{Hex})$} \\
\hline a & C & a & C \\
\hline 9.017 & 3.327 & 8.981 & 3.313 \\
\hline \multicolumn{4}{|c|}{$\mathrm{y}-\mathrm{Ni}(\mathrm{cfc})$} \\
\hline \multicolumn{2}{|c|}{$\mathrm{a}$} & \multicolumn{2}{|c|}{$a$} \\
\hline \multicolumn{2}{|c|}{3.569} & \multicolumn{2}{|c|}{3.568} \\
\hline
\end{tabular}

Tabela 5.30 - Comparativo entre o parâmetro de rede das fases presentes na junta brasada do AID UNS S32304 e o parâmetro de rede das fichas JCPDS.

\begin{tabular}{|c|c|c|c|c|c|}
\hline \multicolumn{3}{|c|}{ UNS32404 } & \multicolumn{3}{|c|}{ Fichas JCPDS } \\
\hline \multicolumn{6}{|c|}{$\mathrm{Ni}_{2} \mathrm{P}(\mathrm{Hex})$} \\
\hline \multicolumn{2}{|l|}{$a$} & C & \multicolumn{2}{|l|}{ a } & C \\
\hline \multicolumn{2}{|c|}{5.870} & 3.328 & 5.86 & & 3.372 \\
\hline \multicolumn{6}{|c|}{$\mathrm{Ni}_{3} \mathrm{P}($ Tetr $)$} \\
\hline \multicolumn{2}{|c|}{$\mathrm{a}$} & C & \multicolumn{2}{|l|}{ a } & C \\
\hline \multicolumn{2}{|c|}{8.975} & 4.300 & 8.95 & & 4.388 \\
\hline \multicolumn{6}{|c|}{$\mathrm{Ni}_{5} \mathrm{P}_{2}(\mathrm{Hex})$} \\
\hline \multicolumn{2}{|l|}{$\mathrm{a}$} & $\mathrm{C}$ & \multicolumn{2}{|c|}{$a$} & C \\
\hline 8.69 & & 5.022 & 8.64 & & 5.070 \\
\hline \multicolumn{6}{|c|}{$\mathrm{Cr}_{12} \mathrm{P}_{7}(\mathrm{Hex})$} \\
\hline \multicolumn{2}{|l|}{$a$} & $\mathrm{C}$ & \multicolumn{2}{|l|}{ a } & C \\
\hline 8.949 & \multicolumn{2}{|r|}{3.348} & \multicolumn{2}{|c|}{8.981} & 3.313 \\
\hline \multicolumn{6}{|c|}{$\mathrm{Cr}_{2} \mathrm{P}(\mathrm{Ort})$} \\
\hline$a$ & b & C & $a$ & $b$ & C \\
\hline 6.609 & 10.402 & 6.337 & 6.427 & 10.447 & 6.305 \\
\hline \multicolumn{6}{|c|}{$\mathrm{y}-\mathrm{Ni}(\mathrm{cfc})$} \\
\hline \multicolumn{3}{|c|}{$\mathrm{a}$} & \multicolumn{3}{|c|}{$\mathrm{a}$} \\
\hline \multicolumn{3}{|c|}{3.557} & \multicolumn{3}{|c|}{3.568} \\
\hline
\end{tabular}


Tabela 5.31 - Comparativo entre o parâmetro de rede das fases presentes na junta brasada do AID UNS S32750 e o parâmetro de rede das fichas JCPDS.

\begin{tabular}{|c|c|c|c|c|c|}
\hline \multicolumn{3}{|c|}{ UNS S32750 } & \multicolumn{3}{|c|}{ Fichas JCPDS } \\
\hline \multicolumn{6}{|c|}{$\mathrm{Ni}_{3} \mathrm{P}$ (Tetr) } \\
\hline \multicolumn{3}{|r|}{ C } & \multicolumn{2}{|l|}{$a$} & C \\
\hline 8,977 & \multicolumn{2}{|r|}{4,369} & 8,952 & \multicolumn{2}{|r|}{4,388} \\
\hline \multicolumn{6}{|c|}{$\mathrm{Ni}_{12} \mathrm{P}_{5}($ Tetr $)$} \\
\hline$a$ & \multicolumn{2}{|r|}{ C } & \multicolumn{2}{|l|}{$a$} & C \\
\hline 8,685 & \multicolumn{2}{|r|}{5,07} & 8,646 & \multicolumn{2}{|r|}{5,07} \\
\hline \multicolumn{6}{|c|}{$\mathrm{Cr}_{3} \mathrm{P}($ Tetr $)$} \\
\hline a & \multicolumn{2}{|r|}{ C } & \multicolumn{2}{|l|}{$a$} & C \\
\hline 9,19 & & 4,58 & 9,19 & & 4,56 \\
\hline \multicolumn{6}{|c|}{$\mathrm{Cr}_{1.2} \mathrm{~N}_{\mathrm{i} 0.8} \mathrm{P}(\mathrm{Ort})$} \\
\hline a & b & $\mathrm{C}$ & $a$ & $b$ & C \\
\hline 5,839 & 3,529 & 6,77 & 5,894 & 3,493 & 6,762 \\
\hline \multicolumn{6}{|c|}{$\mathrm{y}-\mathrm{Ni}(\mathrm{cfc})$} \\
\hline \multicolumn{3}{|c|}{ a } & \multicolumn{3}{|c|}{ a } \\
\hline \multicolumn{3}{|c|}{3.558} & \multicolumn{3}{|c|}{3.554} \\
\hline
\end{tabular}

Tabela 5.32 - Comparativo entre o parâmetro de rede das fases presentes na junta brasada do AID UNS S32707 e o parâmetro de rede das fichas JCPDS.

\begin{tabular}{|c|c|c|c|c|c|}
\hline \multicolumn{3}{|c|}{ UNS32707 } & \multicolumn{3}{|c|}{ Fichas JCPDS } \\
\hline \multicolumn{6}{|c|}{$\mathrm{Ni}_{2} \mathrm{P}(\mathrm{Hex})$} \\
\hline a & \multicolumn{2}{|r|}{ C } & \multicolumn{2}{|l|}{$a$} & C \\
\hline 5,872 & \multicolumn{2}{|r|}{3,374} & 5,862 & \multicolumn{2}{|r|}{3,372} \\
\hline \multicolumn{6}{|c|}{$\mathrm{Ni}_{3} \mathrm{P}($ Tetr $)$} \\
\hline $\mathrm{a}$ & \multicolumn{2}{|r|}{ C } & \multicolumn{2}{|l|}{ a } & C \\
\hline 8,956 & \multicolumn{2}{|r|}{4,412} & 8,952 & \multicolumn{2}{|r|}{4,388} \\
\hline \multicolumn{6}{|c|}{$\mathrm{Ni}_{5} \mathrm{P}_{2}$ (Tetr) } \\
\hline a & \multicolumn{2}{|r|}{ C } & $a$ & \multicolumn{2}{|r|}{ C } \\
\hline 13,245 & \multicolumn{2}{|r|}{24,637} & 13,220 & \multicolumn{2}{|r|}{24,632} \\
\hline \multicolumn{6}{|c|}{$\mathrm{Cr}_{3} \mathrm{P}($ Tetr $)$} \\
\hline a & \multicolumn{2}{|r|}{ C } & $a$ & \multicolumn{2}{|r|}{ C } \\
\hline 9,175 & & 4,555 & 9,190 & & 4,560 \\
\hline & & $\mathrm{Cr}_{12} \mathrm{P}$ & Hex) & & \\
\hline $\mathrm{a}$ & & $\mathrm{C}$ & $\mathrm{a}$ & & C \\
\hline 8,996 & & 3,350 & 8,981 & & 3,313 \\
\hline & & $\mathrm{Cr}_{1.2} \mathrm{Ni}$ & (Ort) & & \\
\hline $\mathrm{a}$ & & $C$ & $\mathrm{a}$ & & C \\
\hline 5,882 & 3,561 & 6,765 & 5,894 & 3,493 & 6,762 \\
\hline & & $\mathrm{Y}-\mathrm{N}$ & fc) & & \\
\hline & a & & & a & \\
\hline & 3.557 & & & 3.554 & \\
\hline
\end{tabular}




\subsection{Medida da folga ideal nos corpos-de-prova estudados.}

As figuras 5.55 a 5.58 apresentam os gráficos comparativos entre a variação das medidas da folga ideal no ensaio da cunha relativo ao tempo de brasagem para os quatro diferentes AID. Estas medidas foram realizadas nos corpos de prova com aberturas de 0,5 $\mathrm{mm}$ e 0,3 $\mathrm{mm}$. Em ambos os casos existe uma leve diferença no valor da medição da folga ideal quando se trata do mesmo tempo de brasagem e abertura da junta. $O$ valor menor da folga ideal é para o menor tempo de brasagem. As diferenças entre as folgas para a mesma abertura e tempos diferentes não é muito significativa, apresentando valores menores de 8 micrometros.

Nas figuras 5.55 e 5.56, correspondentes aos AILD UNS S32101 e UNS S32304, a folga ideal média para o tempo de 12 min é de aproximadamente 25 micrometros e a folga ideal para o tempo de 32 min é de 43 micrometros. Estes valores mostram-se menores quando comparados com os do AISD UNS S32750 e AIHD UNS S32707, que apresentam valores médios de 33 e 54 micrometros para os tempos de 12 e 32 minutos, respectivamente. Este efeito está associado aos teores diferenciados de níquel entre os AID baixa liga (lean duplex) e AID alta liga (super e hiperduplex).

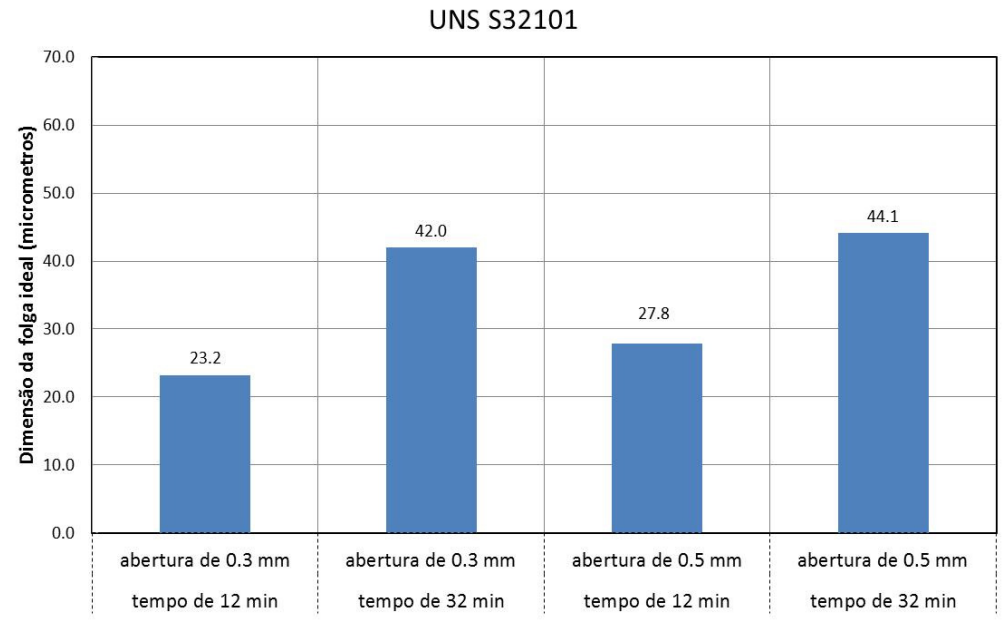

Figura 5.55 - Medida da folga ideal no ensaio da cunha para o AID UNS S32101 nos tempos de brasagem de 12 e 32 min. 
UNS S32304

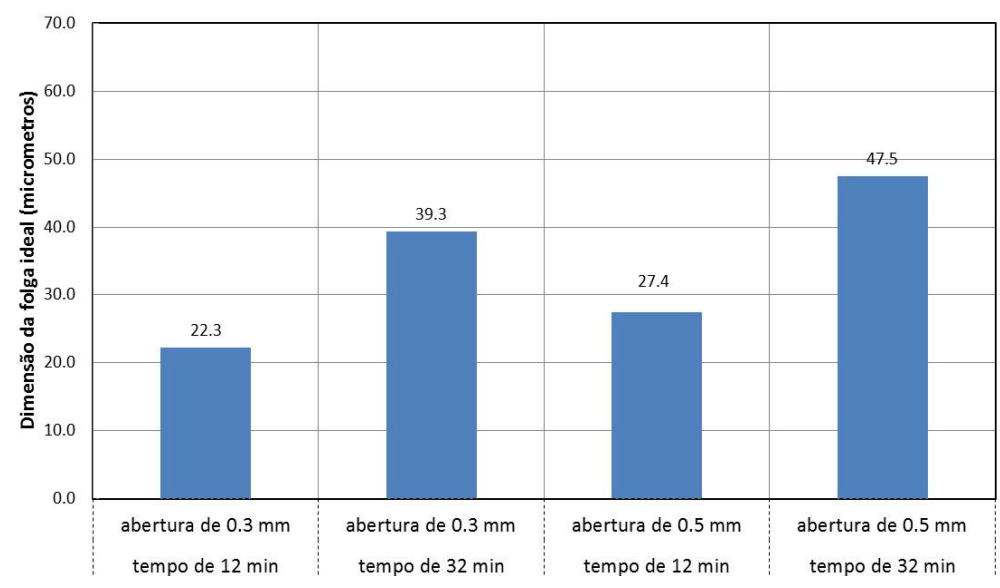

Figura 5.56 - Medida da folga ideal no ensaio da cunha para o AID UNS S32304 nos tempos de brasagem de 12 e 32 min.

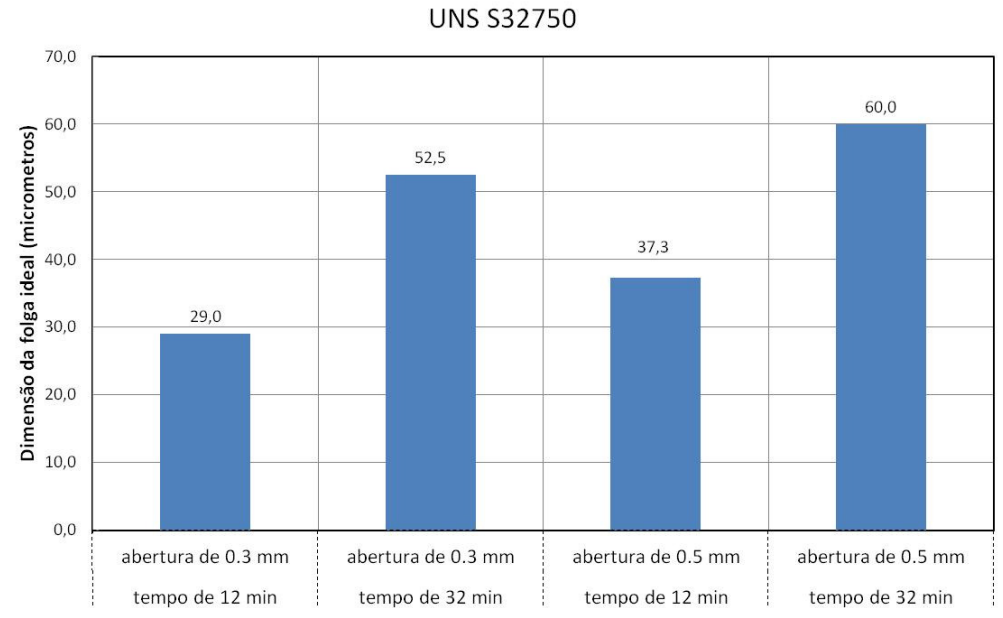

Figura 5.57 - Medida da folga ideal no ensaio da cunha para o AID UNS S32750 nos tempos de brasagem de 12 e 32 min.

UNS S32304

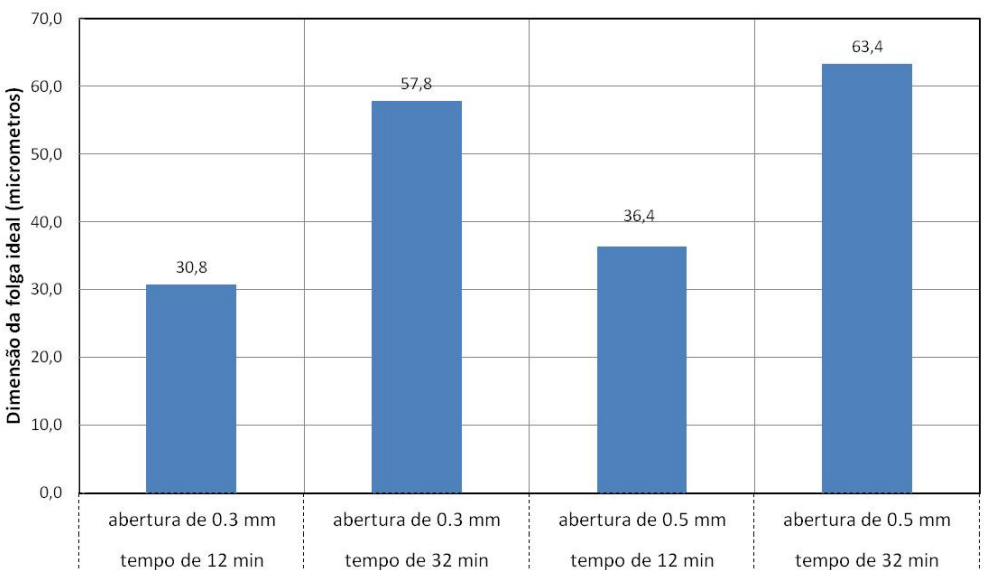

Figura 5.58 - Medida da folga ideal no ensaio da cunha para o AID UNS S32707 nos tempos de brasagem de 12 e $32 \mathrm{~min}$. 


\subsection{Determinação da composição química da junta brasada.}

Foram realizadas barreduras de EDS em áreas determinadas na abertura de 0,3 mm e folga de 0,0 mm nas juntas brasadas dos AID UNS S32101 e UNS S32750, com a finalidade de determinar a composição química de tais regiões após brasagem como observado na figura 5.59. Os valores obtidos estão apresentados na tabela 5.33. A escolha destes dois AID está relacionada com uma questão de fases microestruturais relativamente diferentes com os outros dos AID. A variação dos teores de elementos nas áreas analisadas quando comparadas com os teores iniciais do metal de adição, atribuem-se à dissolução do metal base assim como a interdifusão de elementos durante o tempo de brasagem até o término da solidificação.

(a)

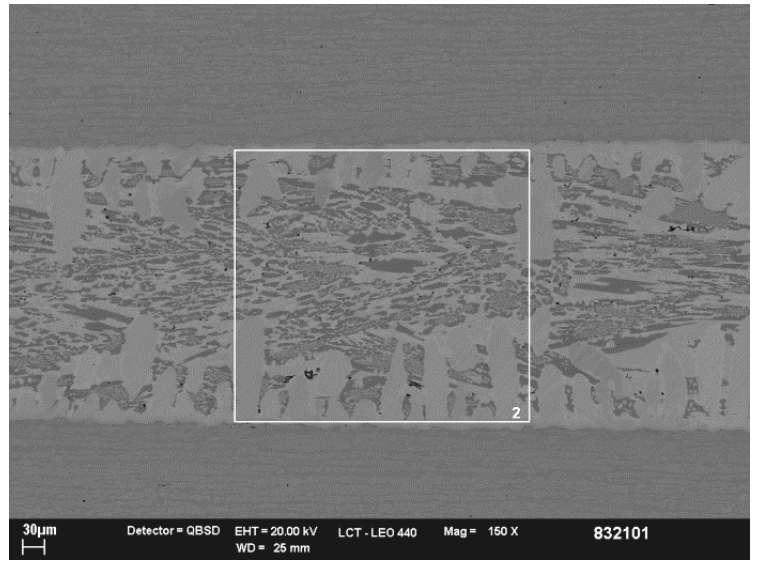

(b)

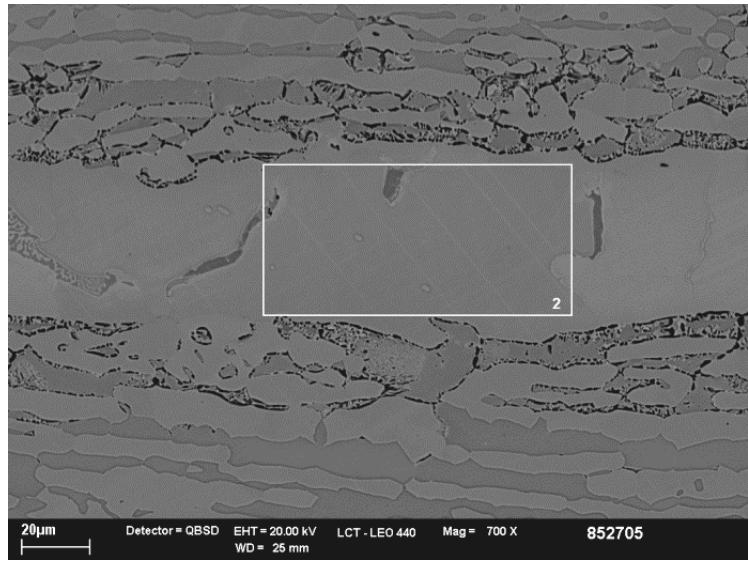

Figura 5.59 - Áreas de análise química via EDS nos AID, (a) aertura de 0,3 mm e (b) 0,0 mm.

Tabela 5.33 - Comparativo da analise química em áreas determinadas da junta brasada para os AID UNS S32101 e UNS S32750.

\begin{tabular}{|c|c|c|c|c|c|c|c|c|}
\cline { 3 - 10 } \multicolumn{2}{c|}{} & \multicolumn{8}{c|}{ Elementos at. \% } \\
\cline { 3 - 10 } \multicolumn{2}{c|}{} & $\mathrm{Si}$ & $\mathrm{P}$ & $\mathrm{Cr}$ & $\mathrm{Fe}$ & $\mathrm{Ni}$ & $\mathrm{Mn}$ & $\mathrm{Mo}$ \\
\hline UNS & Metal de adição & 0.09 & 17.33 & 14.01 & 0.05 & 68.52 & 0.00 & 0.00 \\
\hline \multirow{2}{*}{ S32101 } & Folga 0.0 mm & 0.88 & 1.55 & 17.8 & 45 & 32.2 & 2.6 & 0 \\
\cline { 2 - 10 } & Abertura de $0.3 \mathrm{~mm}$ & 0.55 & 10.5 & 17.3 & 24.6 & 45.5 & 1.54 & 0 \\
\hline & & & & & & & & \\
\hline \multirow{2}{*}{ S32750 } & Folga $0.0 \mathrm{~mm}$ & 0.64 & 2.05 & 23.7 & 50.7 & 21.4 & 0 & 1.6 \\
\cline { 2 - 10 } & Abertura de $0.3 \mathrm{~mm}$ & 0.43 & 11 & 20.5 & 27.1 & 40.1 & 0 & 0.96 \\
\hline
\end{tabular}


As figuras 5.60 e 5.61 apresentam de uma maneira gráfica a variação das porcentagens de elementos de liga quando comparados com as porcentagens iniciais destes elementos no metal de adição como recebido.

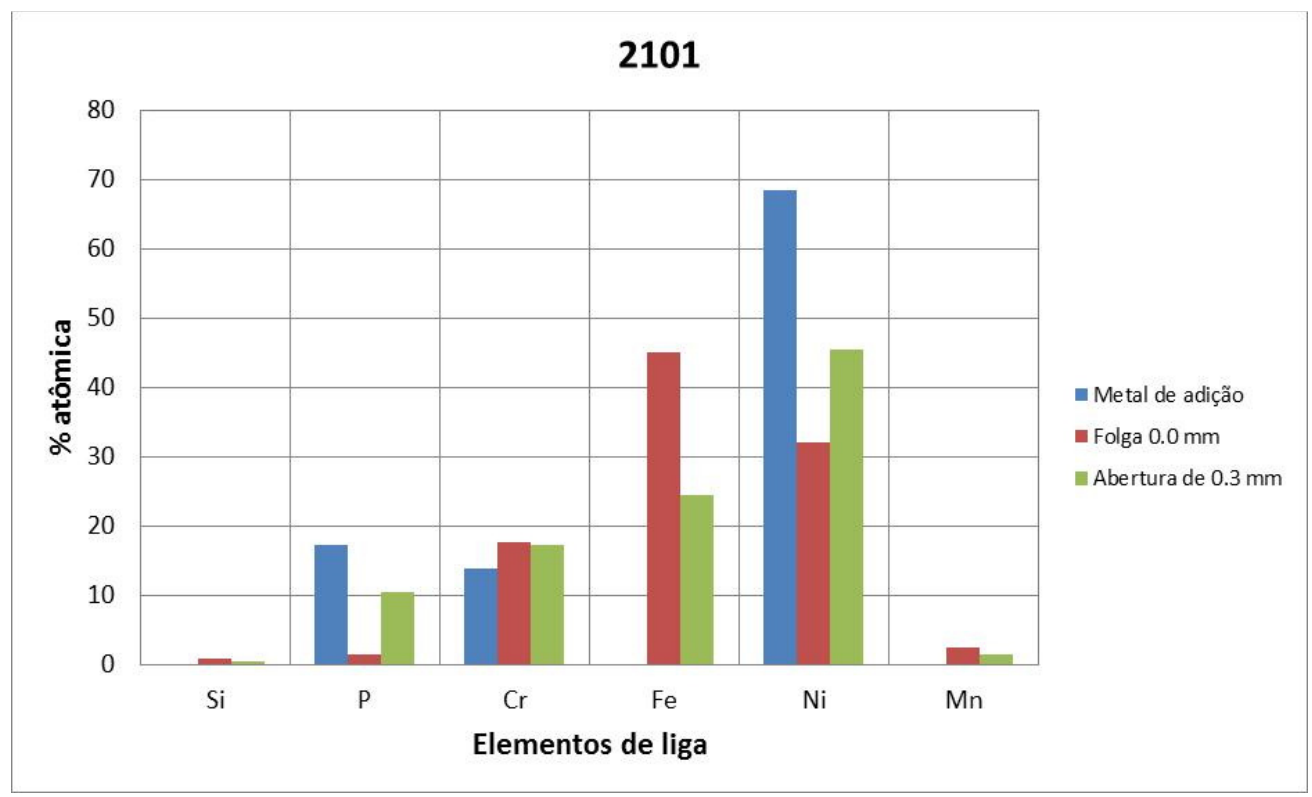

Figura 5.60 - Variação dos elementos de liga após brasagem para o AID UNS S32101 para a folga de $0,3 \mathrm{~mm}$ e $0,0 \mathrm{~mm}$.

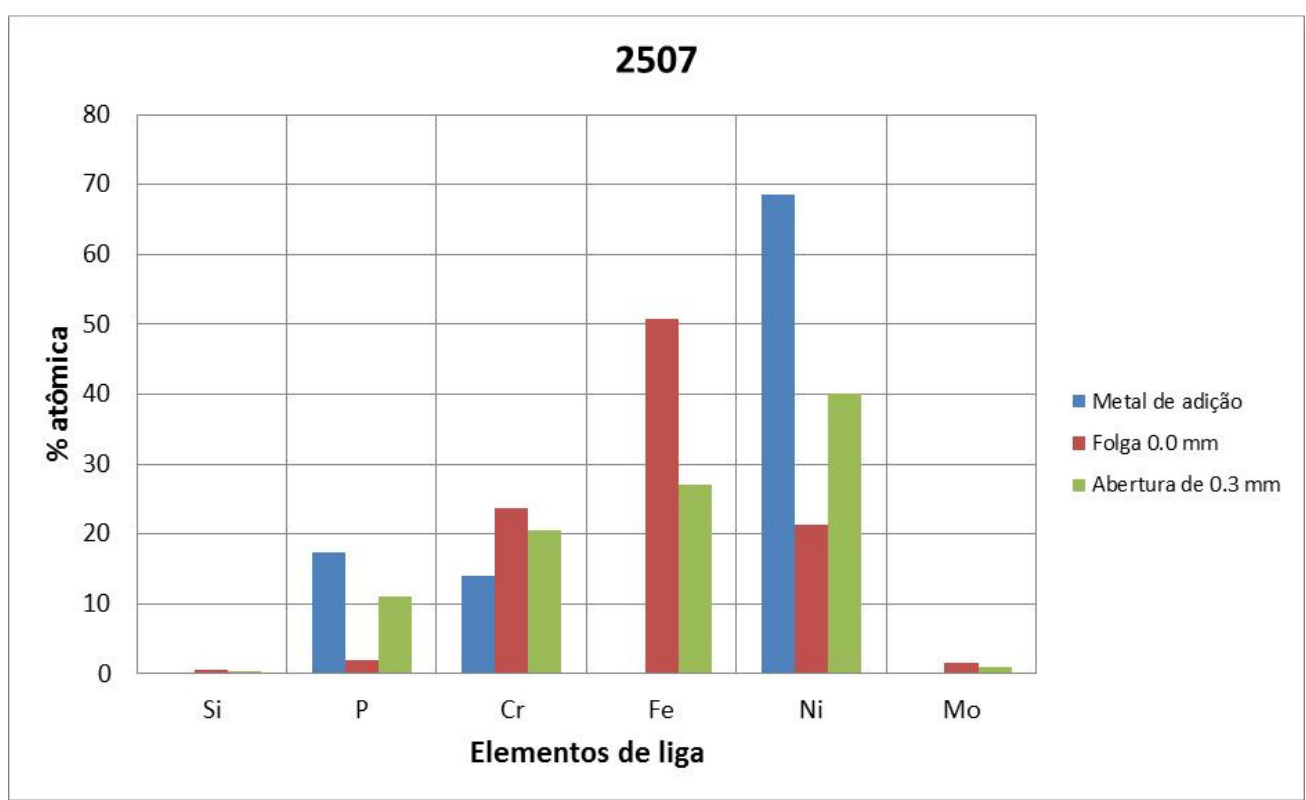

Figura 5.61 - Variação dos elementos de liga após brasagem para o AID UNS S32101 para a folga de $0,3 \mathrm{~mm}$ e $0,0 \mathrm{~mm}$. 
Observando-se as figuras 5.60 e 5.61 nota-se que há um decréscimo nos teores de $\mathrm{P}$ e $\mathrm{Ni}$ e um acréscimo de $\mathrm{Cr}$ e $\mathrm{Fe}$ para todas as condições, com relação à composição do metal de adição.

Para o UNS S32101, comparando-se a composição química do metal de adição inicial com as obtidas por EDS das folga de $0.0 \mathrm{~mm}$ e da abertura de $0,3 \mathrm{~mm}$. Percebe-se que o $\mathrm{P}$ e o $\mathrm{Ni}$ têm uma diminuição pronunciada sendo maior para a folga de 0,0 mm, já o Cr permaneceu praticamente constante. Por outro lado, o $\mathrm{Fe}$, que o seu teor na composição inicial do metal de adição é quase nulo, apresenta-se em porcentagens altas nas duas condições. Este fenômeno também é observado no Mn, porém de maneira mais discreta.

Ao estabelecer um comparativo da composição química inicial do metal de adição com a obtida por EDS para o AISD UNS S32750 percebe-se que o comportamento é similar ao do AID UNS S32101, porém as porcentagens de todos os elementos são relativamente maiores, com exceção do manganês. 


\section{DISCUSSÃO DOS RESULTADOS}

\subsection{Amostra como recebida}

\subsubsection{Microestrutura}

O material como recebido apresenta para todos os AID as fases austeniticas e ferríticas, sendo o tamanho de grão similar para os AID's UNS S32101 e UNS 32403, pois estes aços possuem a mesma espessura $(3 \mathrm{~mm})$ e tiveram durante a laminação as mesmas características de recristalização das fases. Entretanto, o AID UNS S32750 ao apresentar uma espessura duas vezes maior do que os outros aços e menor refino de grão, poder-se-ia inferir que quando laminado o grau de deformação na chapa foi maior obtendo-se grãos mais grosseiros. Por outro lado, a alteração no formato dos grãos na direção transversal do AID UNS S32707 estaria relacionada à forma tubular do material, não sendo uma chapa como os outros aços.

\subsection{Junta brasada}

\subsubsection{Caracterização microestrutural}

\subsubsection{Efeito do tipo de AID no desenvolvimento da microestrutura da junta brasada.}

O desenvolvimento da microestrutura da junta brasada depende basicamente do ciclo térmico (tempo e temperatura) e da folga da junta, para um dado metal de base 
e um dado metal de adição. Assim, existe uma considerável influência na microestrutura da junta quando se trata de metais de base com concentrações elevadas de elementos de liga, assim como a elevada miscibilidade com o metal de adição. Este fato pode ser constatado ao se comparar o desenvolvimento da microestrutura da junta dos AID's baixa liga, passando pelo superduplex e finalizando com o aço hiperduplex, nas diferentes condições de brasagem.

$\mathrm{Na}$ condição 1 de brasagem, os AID baixa liga UNS S32101 (figuras 5.2) e UNS S32304 (figuras 5.3), apresentam na interface uma camada contínua de solução sólida com crescimento dendrítico discreto dos grãos para o centro da junta. Por outro lado, o AISD UNS S32750 (figuras 5.4) e AIHD UNS S32707 (figuras 5.5), desenvolveram uma camada de solução sólida com grãos maiores mostrando a mesma tendência de crescimento dendrítico para o centro da junta, e distribuídos aleatoriamente na região central. Esta diferença poderia estar relacionada à interdifusão de elementos de liga como o níquel e cromo durante a solidificação isotérmica, sendo mais intensa para os AID com altos teores destes elementos. Assim a alta saturação de níquel e cromo promoveria a formação de maior quantidade de cristais de solução sólida na junta, além de promover a formação de microestruturas eutetóides, como pode ser verificado nas micrografias obtidas, tanto por microscopia óptica (figuras 5.2 a 5.5) e MEV (figuras 5.26 a 5.29) da região brasada dos AID UNS S32750 e UNS S32707.

Constata-se também que na condição 2 a microestrutura da junta dos AID's baixa liga UNS S32101 (figuras 5.6) e UNS S32304 (figuras 5.7) difere do AISD UNS S32750 (figuras 5.8) e AIHD UNS S32707 (figuras 5.9), pois existe uma maior formação de ilhas de solução sólida rica em níquel na junta brasada para os AID baixa liga. Porém a microestrutura formada nos AID UNS S32750 e UNS S32707 apresentam fases mais estáveis sem presença de fases eutéticas.

Por outro lado, a condição 3 onde a folga é $0,0 \mathrm{~mm}$ (sem folga), observa-se tanto por microscopia óptica assim como por MEV a presença de pequenas "ilhas" de fosfatos distribuídas no centro da junta para os quatro tipos de AID. No entanto, os AID's com maior quantidade de elementos de liga como são o AISD UNS S32750 e o AIHD UNS S32707 apresentam estas "ilhas" em maior proporção podendo-se ver 
inclusive, zonas de fases eutéticas, como observado na figura 5.36 correspondente ao AIHD UNS S32707. Portanto, corrobora-se a grande influência que exerce o grau de elementos de liga do material base na microestrutura final da junta.

A influência do grau de elementos de liga do metal base na microestrutura pode ser corroborada quantitativamente mediante a comparação da porcentagem de $\mathrm{Ni}$ na solução sólida ("a"), assim como nos fosfatos ("b" e "c"), formados na junta brasada. Estes valores porcentuais obtidos por EDS das condições 1 e 2 de brasagem estão expressados mais claramente nos gráficos 6.1 e 6.2 respectivamente. $O$ fato de serem usadas as condições de brasagem com maior tempo (32min) justifica-se pela representatividade mostrada pelo tempo de interdifusão que quando comparado com a brasagem com menor tempo de brasagem (condições 4,5 e 6.) a diferença existente entre um e outro aço referente ao grau de elementos de liga não é tão perceptível.

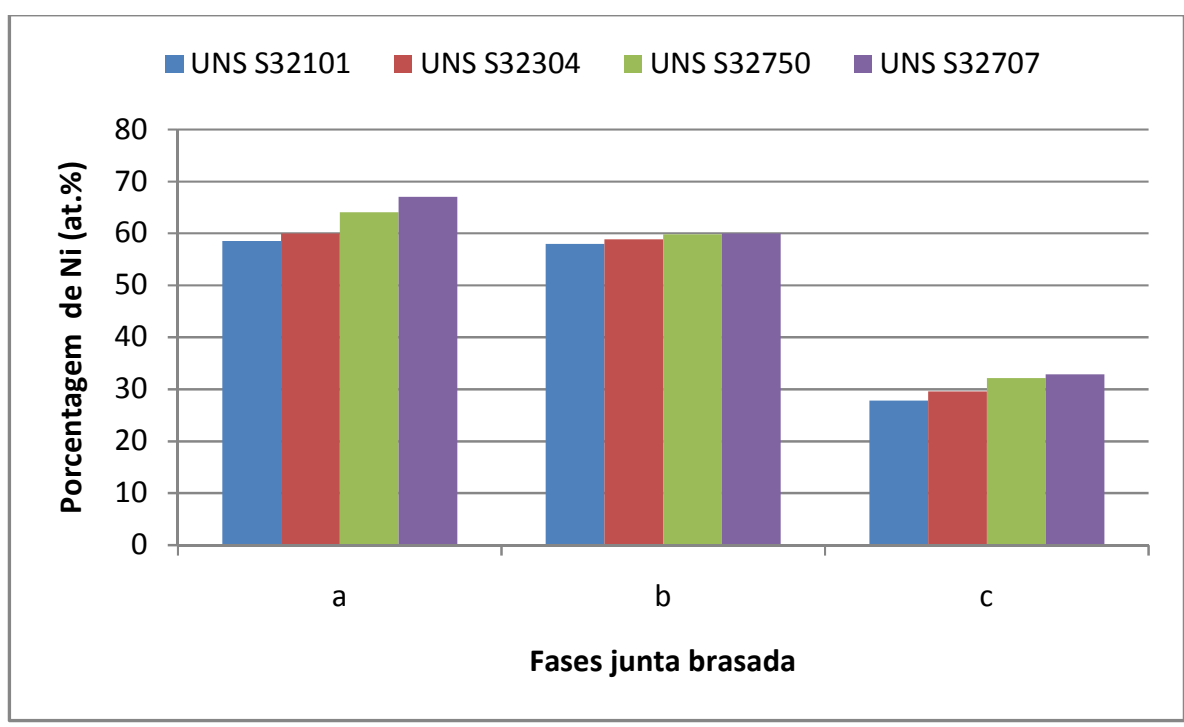

Figura 6.1 - Gráfico comparativo entre a porcentagem de Ni entre as fases encontradas na junta brasada da condição 1 . 


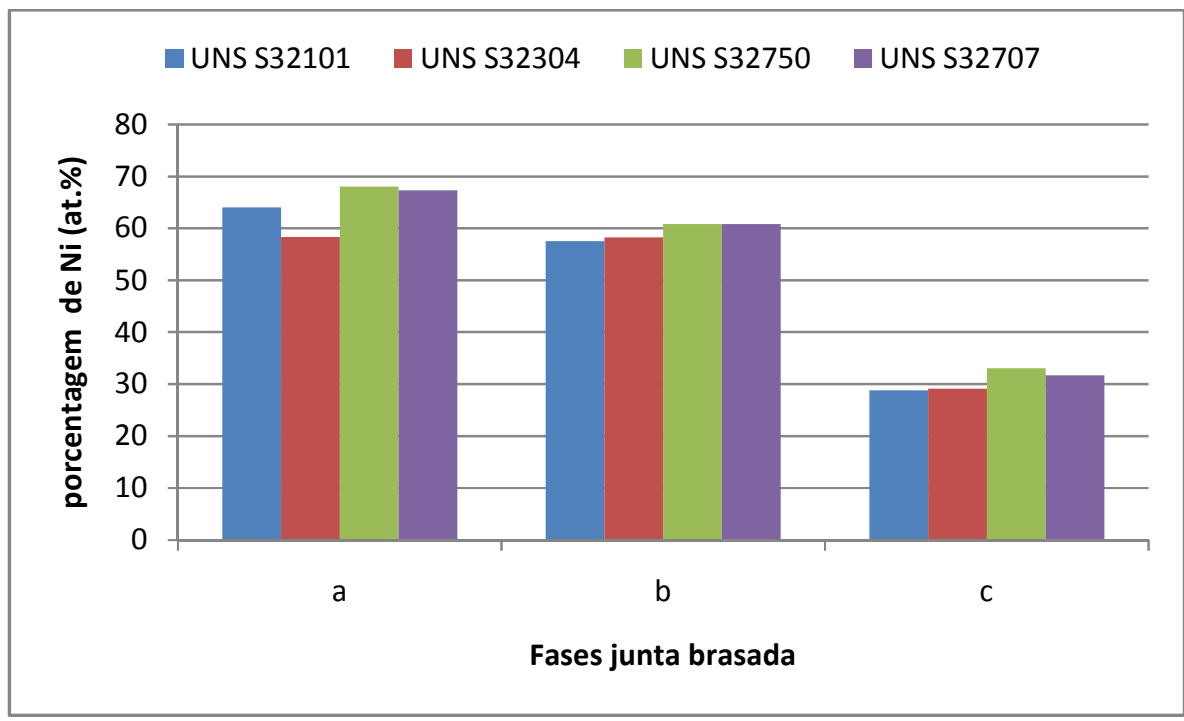

Figura 6.2 - Gráfico comparativo entre a porcentagem de Ni entre as fases encontradas na junta brasada da condição 2 .

\subsubsection{Efeito da folga no desenvolvimento da microestrutura da junta brasada.}

Para as condições de folga da junta $(0,5 ; 0,3$ e $0,0 \mathrm{~mm})$, definidas nos quatro AID, observou-se que conforme se diminui a distância, a microestrutura da junta apresenta maior fração volumétrica da solução sólida rica em níquel, $\gamma$-Ni. Este resultado pode ser observado na figura 6.3, a qual apresenta a tendência de desenvolvimento da microestrutura para qualquer tipo de AID. Este resultado ocorre porque a espessura de $\gamma$-Ni é praticamente a mesma para as três folgas apresentadas na figura 6.3 .

(a)

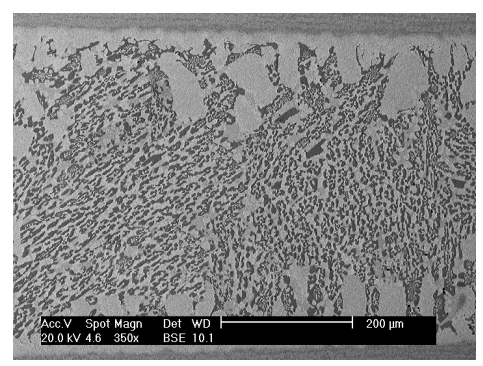

(b)

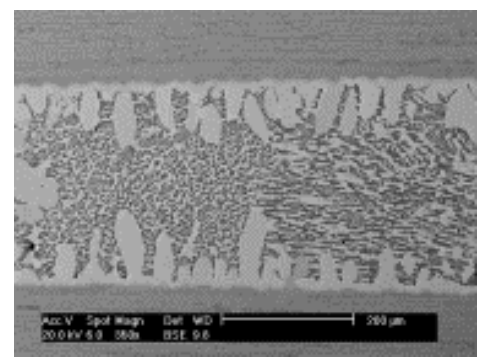

(c)

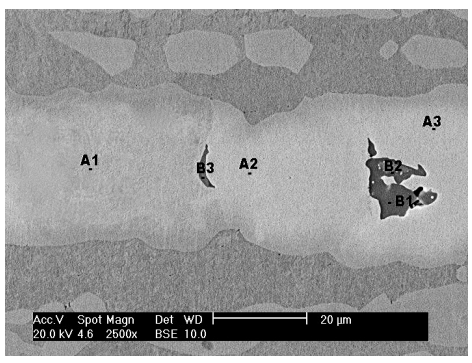

Figura 6.3 - Desenvolvimento da microestrutura brasada em função do tamanho de folga para o aço duplex UNS S32101 e tempo de brasagem de $32 \mathrm{~min}$. (a) Folga de 0,5 mm; (b) folga de 0,3 $\mathrm{mm}$ e (c) folga de $0,0 \mathrm{~mm}$. 


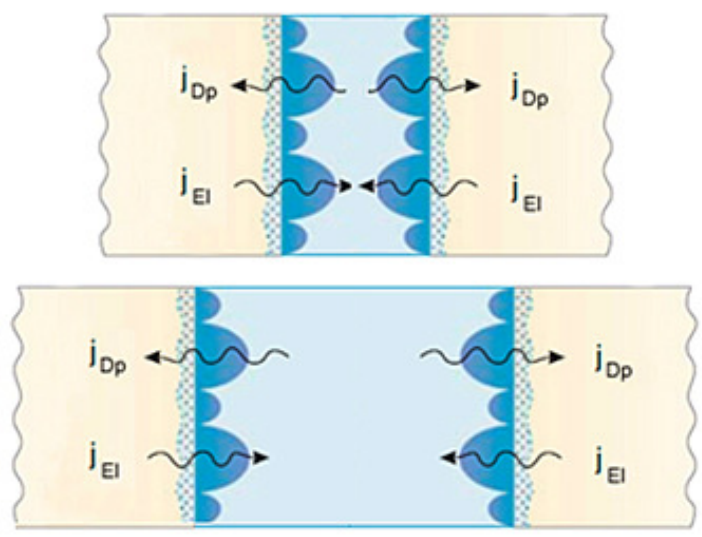

Figura 6.4 - Representação do desenvolvimento microestrutural da solução sólida rica em níquel, $\gamma$ $\mathrm{Ni}$, a partir da interface para duas dimensões de folgas diferentes.

O aumento na fração volumétrica de $\gamma$-Ni conforme diminui o tamanho da folga é explicado mediante a figura 6.4. No inicio da brasagem o metal de adição líquido ao entrar em contato com o metal de base promove a dissolução do mesmo provocando o aumento no teor de níquel e consequentemente a formação de pontos de nucleação para a solução sólida. Enquanto a interface permanece com regiões em contato com o metal líquido o crescimento dos grãos de $\gamma$-Ni é rápido, pois a difusão de fósforo para o metal de base é direta. Ao desaparecer estas regiões o crescimento dos grãos de $\gamma$-Ni é lenta e a difusão de fósforo e praticamente nula, permanecendo no metal liquido o qual fica sobressaturado de fósforo. Ao diminuir o tamanho da folga o fenômeno é o mesmo, porem o volume de metal liquido diminui e por consequência o fósforo presente. Por tanto, quando a folga é pequena a junta é preenchida pela solução sólida rica em níquel, já que o fósforo difunde para o metal base ou é dissolvido em $\gamma$-Ni.

\subsubsection{Efeito do tempo no desenvolvimento da microestrutura da junta brasada.}

Ao analisar o efeito do tempo de brasagem (32 e $12 \mathrm{~min}$ ) no desenvolvimento da microestrutura da junta brasada (morfologia e fases formadas) para os diferentes tamanhos de folga nos AID's, estabeleceu-se um claro diferencial na formação da solução sólida rica em níquel e os intermetálicos. Tal desenvolvimento depende 
basicamente do tempo de difusão do elemento depressor da temperatura, sendo neste caso o fósforo, e da dissolução do metal base.

Independente do tipo de AID para o menor tempo de brasagem (12 min) a microestrutura da junta desenvolve uma grande quantidade de eutéticos e fases metaestáveis. No caso do maior tempo de brasagem ,32 min, existe baixa presença de eutéticos com tendências a formar fases mais estáveis. Este comportamento é claramente observado nos AID's baixa liga, ao se comparar as figuras 5.26 e 5.27 correspondente ao AID UNS S32101 e as figuras 5.38 e 5.39 correspondente ao AID UNS S32304. Nota-se que nos casos de maior tempo (condição 1e 2) a morfologia e distribuição das três fases tendem à estabilidade, não apresentando fases eutéticas. Porém uma exceção é observada no AIHD UNS S32707 o qual apresenta fases eutéticas, embora sua presença não seja severa. Em contrapartida, no caso de menor tempo de brasagem, condições 4 e 5, são observadas, sem exceção, microestruturas com grandes quantidades de fases eutéticas (figuras 5.41 e 5.45).

Uma análise separada das condições 3 e 6 apresenta uma visão diferente do efeito do tempo quando se tem folgas extremamente pequenas ou de topo. $A$ microestrutura para o tempo de 32 min apresenta pequenas regiões compostas por um ou dois intermetálicos, como visto para os AID baixa liga (figuras 5.34 e 5.35) e AID alta liga (figuras 5.36 e 5.37), respectivamente. Por outro lado, a microestrutura desenvolvida para o tempo de 12 min mostra para os quatro tipos de AID (figuras 5.46 e 5.49) uma linha central continua composta por duas fases intermetálicas contendo inclusive fases eutéticas, como observado no caso do AISD UNS S32750 (figuras 5.48) e AIHD UNS S32707(figuras 5.49).

\subsubsection{Identificação das fases por EDS e Difração de Raios X}

Com base na relação estequiométrica $[(\mathrm{Ni}+\mathrm{Cr}) / \mathrm{P}]$ e $(\mathrm{Ni} / \mathrm{P})$ das fases "b" e "c" nas condições 1, 2 , 4 e 5 , assim como para as fases "B" e "C" nas condições 3 e 6 é possível estabelecer a identificação das fases utilizando os diagramas de fase Ni-P e Cr-P apresentados na figura 6.5. Ao se observar os valores da relação das concentrações atômicas $[(\mathrm{Ni}+\mathrm{Cr}) / \mathrm{P}]$ e $(\mathrm{Ni} / \mathrm{P})$ nas seis condições na tabela 6.1, existe 
uma aproximação dos valores obtidos, apesar da diferença nos parâmetros de soldagem entre condições. Desta forma, a media dos valores obtidos das condições 1 , 2, 4 e 5 das fases "b" e "c" para a relação $[(\mathrm{Ni}+\mathrm{Cr}) / \mathrm{P}]$ é 1,89, esta relação por estar próxima de 2 as fases poderiam ser identificadas como fosfetos $\mathrm{Ni}_{2} \mathrm{P}$ ou $\mathrm{Cr}_{2} \mathrm{P}$ como indicado nos diagramas de fase Ni-P e Cr-P. Por outro lado, para a relação (Ni/P) a media dos valores obtidos é 2,59, com uma aproximação no valor de 2,5 na relação, indicando uma possível identificação das fases como os fosfetos de níquel $\mathrm{Ni}_{5} \mathrm{P}_{2}$ ou $\mathrm{Ni}_{12} \mathrm{P}_{5}$.
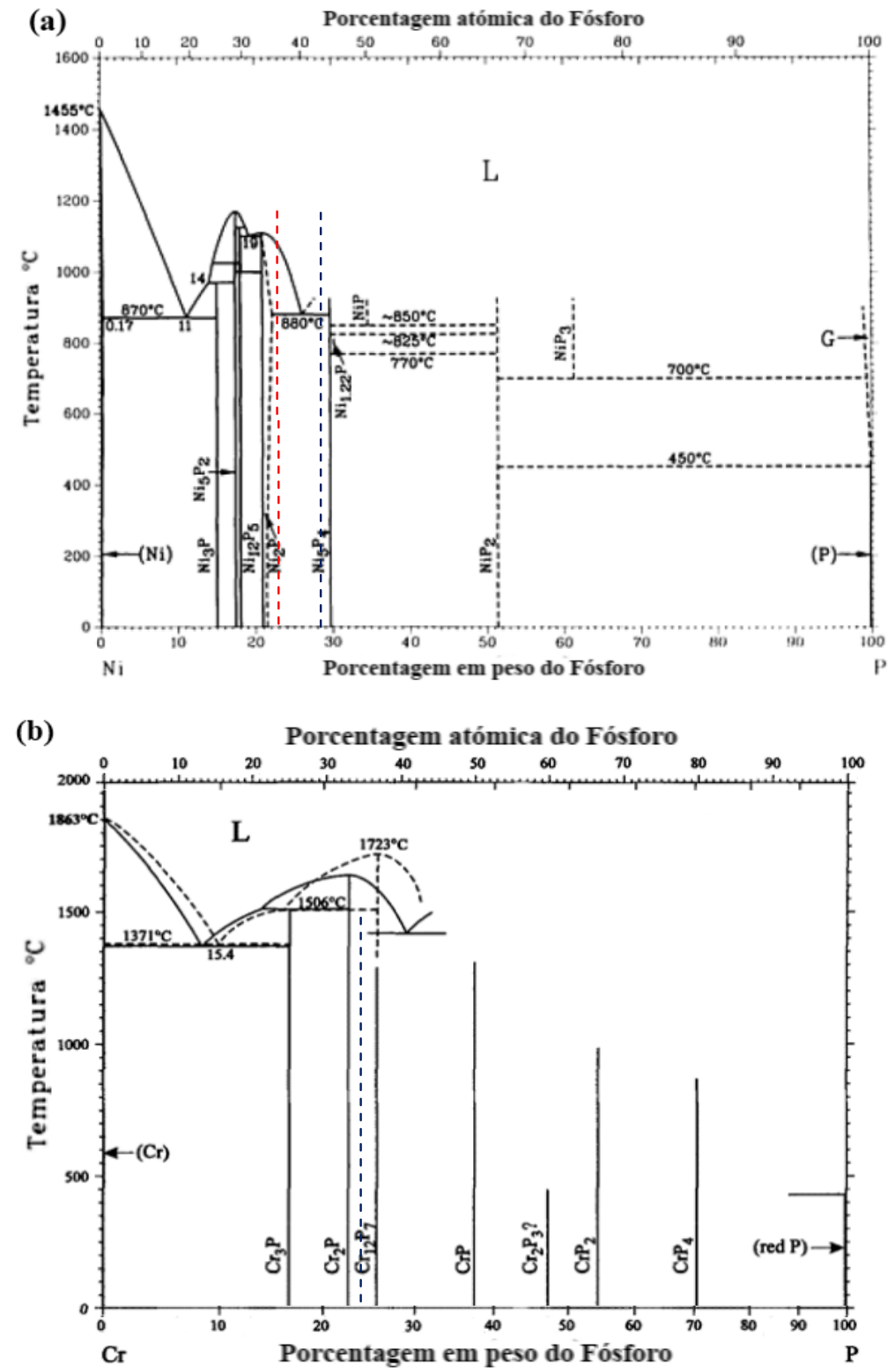

Figura 6.5 - Diagramas de fase. (a) Ni-P e (b) Cr-P. 
Tabela 6.1 - Comparação da relação estequiométrica $[(\mathrm{Ni}+\mathrm{Cr}) / \mathrm{P}]$ e $(\mathrm{Ni} / \mathrm{P})$ das fases formadas na junta brasada para os quatro AID.

\begin{tabular}{|c|c|c|c|c|c|}
\hline \multirow[b]{2}{*}{ Condição } & \multirow[b]{2}{*}{ Relação } & \multicolumn{4}{|c|}{ Material } \\
\hline & & $\begin{array}{c}\text { UNS } \\
\text { S32101 }\end{array}$ & $\begin{array}{c}\text { UNS } \\
\text { S32304 }\end{array}$ & $\begin{array}{c}\text { UNS } \\
\text { S32750 }\end{array}$ & $\begin{array}{c}\text { UNS } \\
\text { S32707 }\end{array}$ \\
\hline \multirow{2}{*}{1} & $(\mathrm{Ni} / \mathrm{P})$ & 2,44 & 2,53 & 2,59 & 2,62 \\
\hline & {$[(\mathrm{Ni}+\mathrm{Cr}) / \mathrm{P}]$} & 1,79 & 1,88 & 1,90 & 1,93 \\
\hline \multirow{2}{*}{2} & $(\mathrm{Ni} / \mathrm{P})$ & 2,59 & 2,93 & 2,78 & 2,88 \\
\hline & {$[(\mathrm{Ni}+\mathrm{Cr}) / \mathrm{P}]$} & 1,90 & 1,99 & 1,97 & 1,92 \\
\hline \multirow{2}{*}{3} & {$[(\mathrm{Ni}+\mathrm{Cr}) / \mathrm{P}]$} & 1.66 & 2.39 & 1,80 & 240 \\
\hline & & & 2,39 & 2,34 & 2,40 \\
\hline \multirow{2}{*}{4} & $(\mathrm{Ni} / \mathrm{P})$ & 2,53 & 2,53 & 2,71 & 2,60 \\
\hline & {$[(\mathrm{Ni}+\mathrm{Cr}) / \mathrm{P}]$} & 1,88 & 1,88 & 2,04 & 1,88 \\
\hline \multirow{2}{*}{5} & $(\mathrm{Ni} / \mathrm{P})$ & 2,36 & 2,52 & 2,39 & 2,45 \\
\hline & {$[(\mathrm{Ni}+\mathrm{Cr}) / \mathrm{P}]$} & 1,86 & 1,86 & 1,76 & 1,87 \\
\hline \multirow{2}{*}{6} & \multirow{2}{*}[(\mathrm{Ni}+\mathrm{Cr})/\mathrm{P}]{} & 2,13 & 2,13 & 2,44 & 2,31 \\
\hline & & 1,54 & 1,63 & 1,88 & 1,96 \\
\hline
\end{tabular}

Afim de uma melhor identificação das fases na junta brasada realizou-se a análise via difração de raios X. A tabela 6.2 apresenta um comparativo das fases identificadas na junta brasada nos quatro diferentes AID. Verifica-se uma maior formação de fases quando se trata do tipo de AID, sendo o número de fases identificadas, maior para o AIHD UNS S32707. A alta quantidade de elementos de liga deste aço promove a formação de fases metaestáveis durante a solidificação isotérmica, não sendo suficiente o tempo de brasagem para atingir fases mais estáveis.

Tabela 6.2- Fases identificadas via difração de raios $X$ nos quatro AID

\begin{tabular}{|c|c|c|c|c|c|c|c|}
\hline \multirow{2}{*}{ AID } & \multicolumn{7}{|c|}{ Fases } \\
\hline UNS S32101 & $\mathrm{Ni}_{2} \mathrm{P}$ & - & $\mathrm{Ni}_{5} \mathrm{P}_{2}$ & - & $\mathrm{Cr}_{12} \mathrm{P}_{7}$ & - & $\gamma-\mathrm{Ni}$ \\
\hline UNS S32304 & $\mathrm{Ni}_{2} \mathrm{P}$ & $\mathrm{Ni}_{3} \mathrm{P}$ & $\mathrm{Ni}_{5} \mathrm{P}_{2}$ & $\mathrm{Cr}_{2} \mathrm{P}$ & $\mathrm{Cr}_{12} \mathrm{P}_{7}$ & - & $\gamma-\mathrm{Ni}$ \\
\hline UNS S32750 & - & $\mathrm{Ni}_{3} \mathrm{P}$ & $\mathrm{Ni}_{12} \mathrm{P}_{5}$ & $\mathrm{Cr}_{3} \mathrm{P}$ & - & $\mathrm{Cr}_{1.2} \mathrm{Ni}_{0.8} \mathrm{P}$ & $\gamma-\mathrm{Ni}$ \\
\hline UNS S32707 & $\mathrm{Ni}_{2} \mathrm{P}$ & $\mathrm{Ni}_{3} \mathrm{P}$ & $\mathrm{Ni}_{5} \mathrm{P}_{2}$ & $\mathrm{Cr}_{3} \mathrm{P}$ & $\mathrm{Cr}_{12} \mathrm{P}_{7}$ & $\mathrm{Cr}_{1.2} \mathrm{Ni}_{0.8} \mathrm{P}$ & $\gamma-\mathrm{Ni}$ \\
\hline
\end{tabular}

Observa-se que, tanto paro o AISD UNS S32750 e o AIHD UNS S32707 há uma formação de fase ternaria $\mathrm{Cr}_{1.2} \mathrm{Ni}_{0.8} \mathrm{P}$, assim como foi identificado no trabalho de $\mathrm{KIM}$ Y. H. et al [62]. A morfologia desta região, segundo KIM é apresentada na figura 6.6 . 


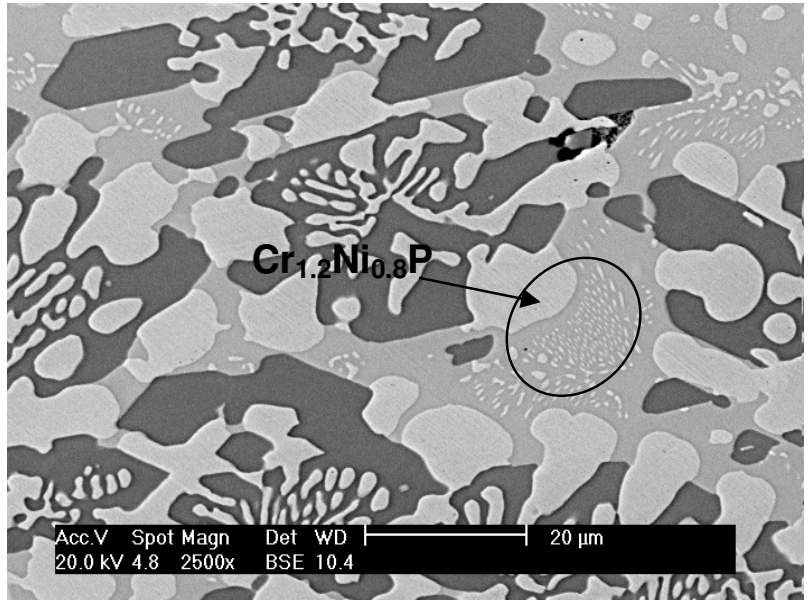

Figura 6.6 - Microfotografia apresentando fase ternaria $\mathrm{Cr}_{1.2} \mathrm{Ni}_{0.8} \mathrm{P}$ na junta brasada do AID UNS32707.

A variação das fases formadas nas juntas brasadas nos quatro diferentes AID pode ser melhor entendida com ajuda da figura 6.7, esta figura apresenta seções do diagrama ternário Ni-Cr-P para uma composição fixa de $79 \% \mathrm{Ni}, 14 \% \mathrm{Cr}$ e $17 \% \mathrm{P}$ para diferentes temperaturas plotadas por thermocalc. Mediante estes diagramas é possível descrever o desenvolvimento das fases durante a solidificação do metal de adição sem considerar a influência do metal base.

As fases que formam o metal de adição inicialmente segundo os teores de $79 \% \mathrm{Ni}$, $14 \% \mathrm{Cr}$ e $17 \% \mathrm{P}$ e o diagrama ternário são $\gamma-\mathrm{Ni}, \mathrm{Ni}_{3} \mathrm{P}$ e $\mathrm{Cr}_{2} \mathrm{P}$. Uma vez fundido o metal de adição a linha de solidificação seguirá a sequencia mostrada nos diferentes diagramas ternário. Ao estabelecer a linha de solidificação para as porcentagens de elementos obtida na tabela 5.33 as fases finais formadas na junta brasada para as duas folgas são: o fosfeto de cromo $\mathrm{Cr}_{2} \mathrm{P}$, o fosfeto de níquel $\mathrm{Ni}_{3} \mathrm{P}$ e $\circ \gamma$-Ni. No entanto, ao comparar com as fases encontradas via difração de raios $\mathrm{X}$, existem quatro fases a mais $\left(\mathrm{Ni}_{2} \mathrm{P}, \mathrm{Ni}_{5} \mathrm{P}_{2}, \mathrm{Ni}_{12} \mathrm{P}_{5}, \mathrm{Cr}_{12} \mathrm{P}_{7}, \mathrm{Cr}_{3} \mathrm{P}, \mathrm{e} \mathrm{Cr}_{1.2} \mathrm{Ni}_{0.8} \mathrm{P}\right)$ que nos diagramas ternários estão presentes para teores de fósforo maiores. Este fenômeno pode ser relacionado ao fato do metal de adição liquido dissolver o metal base e variar os teores de elementos no volume de metal líquido, aumentando a presença de outros elementos como o ferro que possivelmente modifica a relação temperatura - composição na estabilidade destas fases. Outra provável explicação é o enriquecimento de fósforo no líquido. 
(a)

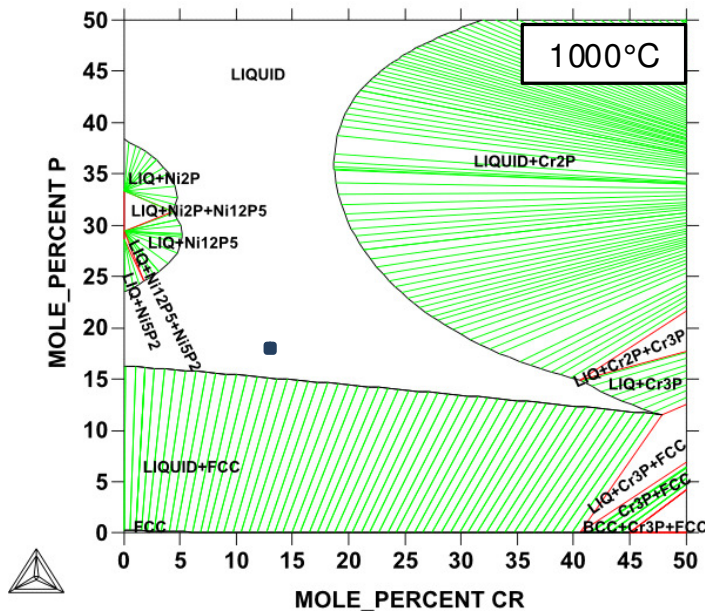

(c)

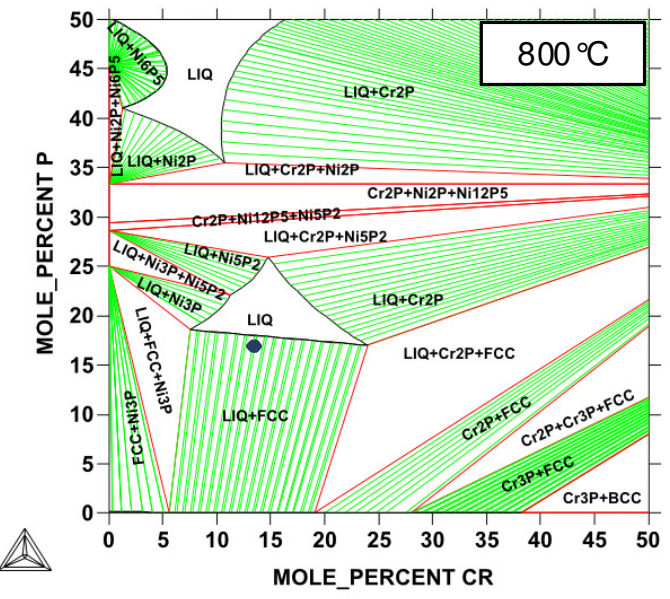

(e)

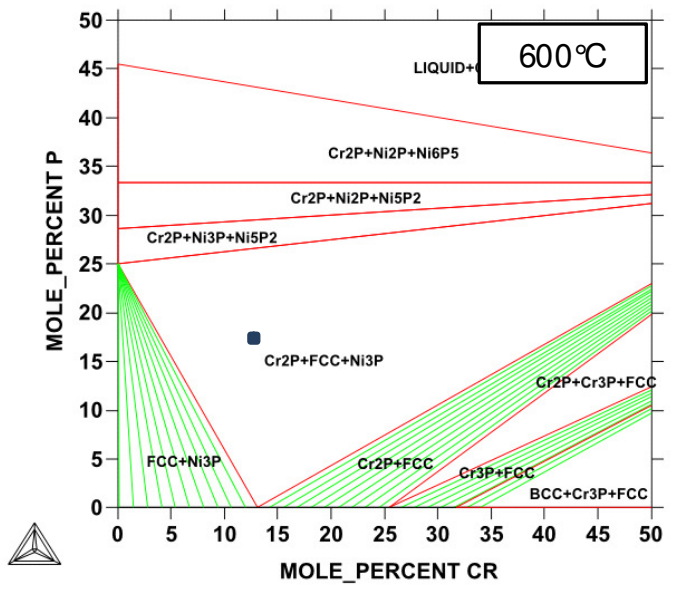

(b)

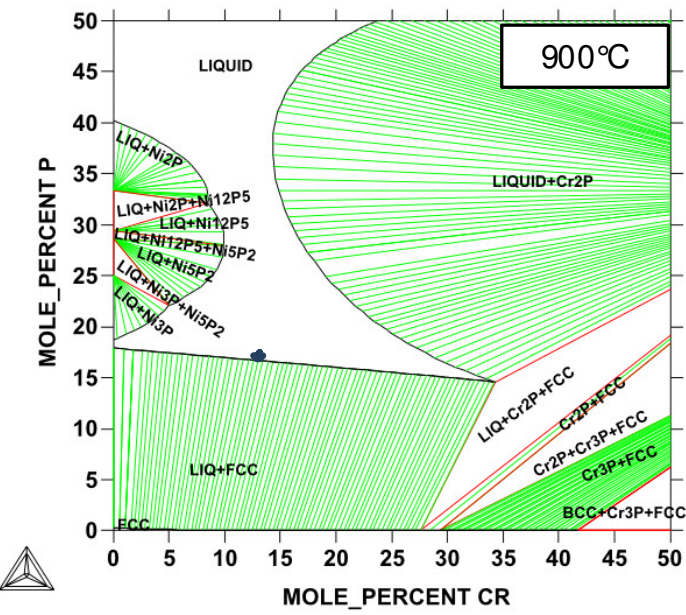

(d)

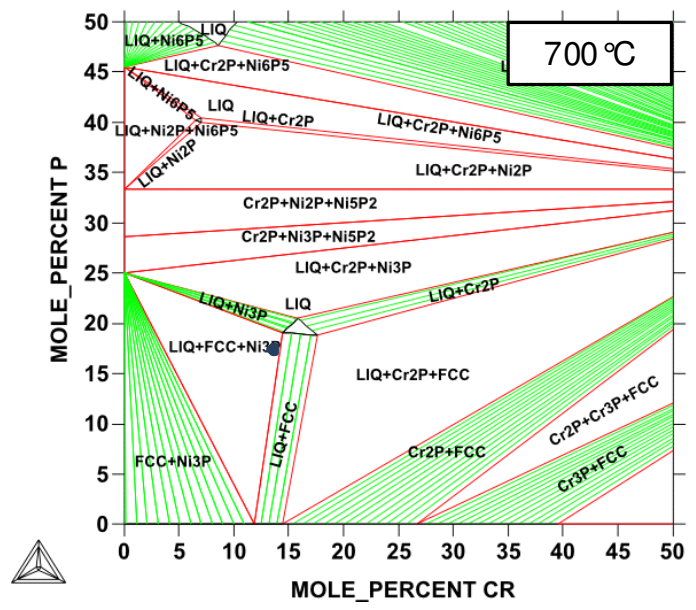

(f)

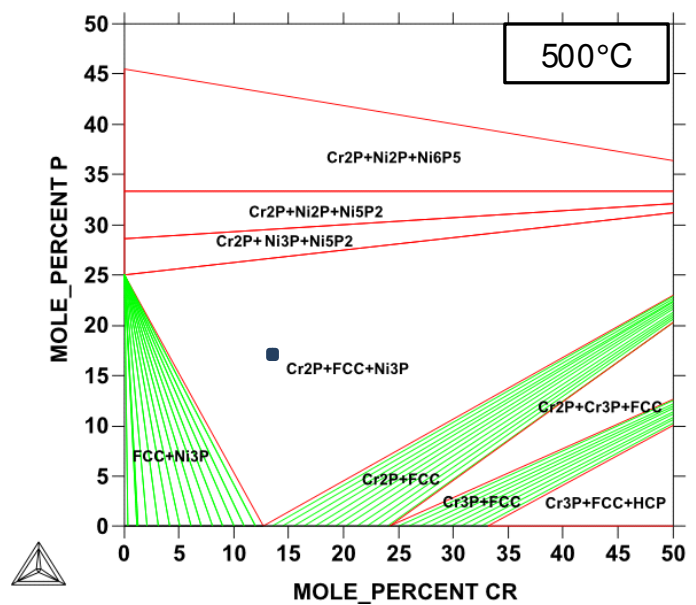

Figura 6.7 - Projeção do diagrama ternario Ni-Cr-P via thermocalc para as temperaturas a) $1000^{\circ} \mathrm{C}$;

b) $900^{\circ} \mathrm{C}$; c) $800^{\circ} \mathrm{C}$; d) 700 ; (e) 600 e (f) 500 . 
A sequencia de desenvolvimento microestrutural estaria regido segundo a figura 6.8 , onde ao finalizar a solidificação nos deparamos com um $\gamma$-Ni eutetico e $\gamma$-Ni primário.

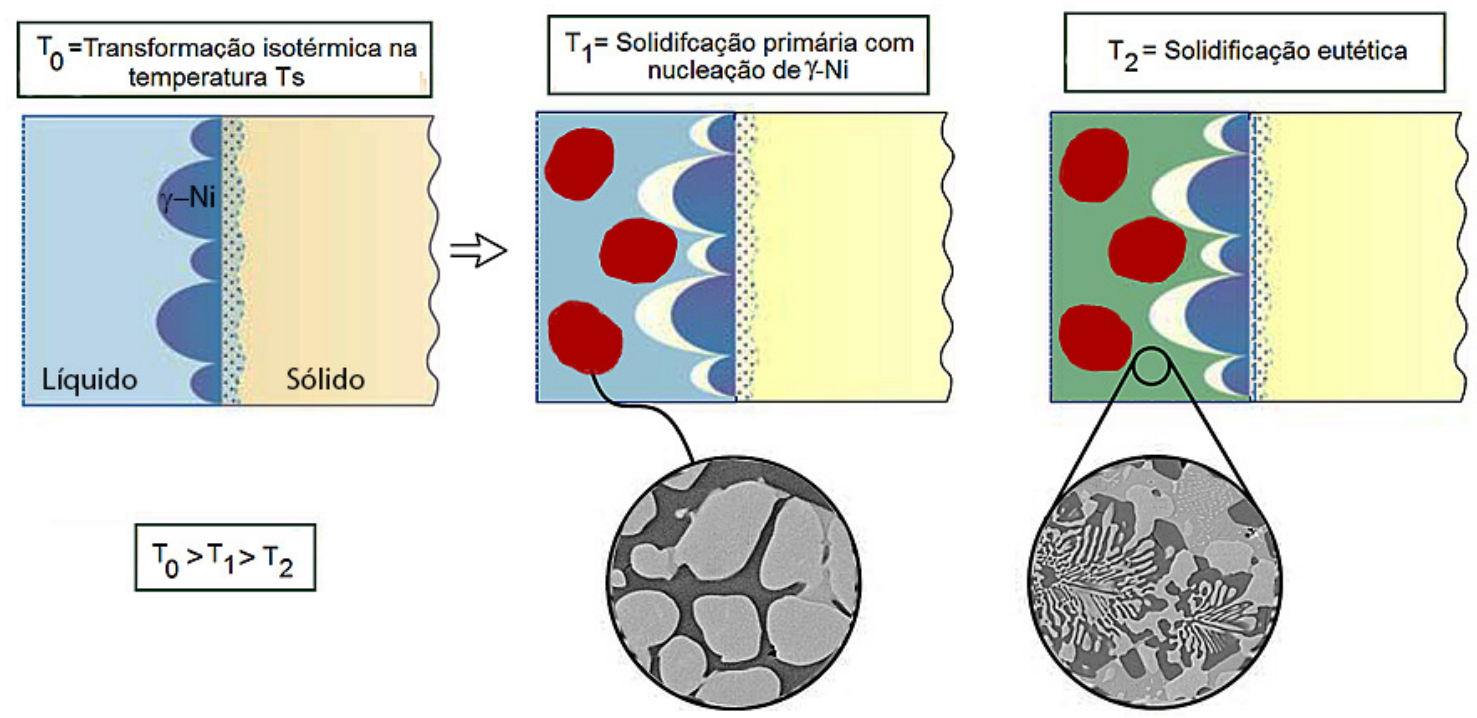

Figura 6.8 - Desenvolvimento das fases durante o resfriamento.

\subsubsection{Brasabilidade dos aços inoxidáveis duplex}

Considerando a análise microestrutural e os ensaios realizados nas diferentes condições de brasagem nos AID's, percebe-se que existe uma notável diferença entre a interação do metal base com o metal de adição dos AID baixa liga (lean duplex) UNS S32101, UNS S32304 e os AID de alta liga UNS S32750, UNS S32707. A região adjacente à interface da junta os AID UNS S32101 e UNS S32304 não foi possível identificar a precipitação de intermetálicos ou formação de fases secundárias no metal de base. No entanto, a região próxima da interface nos AID UNS S32750 e UNS S32707 existe uma forte decomposição do metal base, mais precisamente da fase ferrítica. Atribui-se pelas suas características que a fase formada é a fase sigma. Este fenômeno mostrou-se mais acentuado para o AlHD UNS S32707, onde tal decomposição aconteceu em todo o metal com severidade na interface, como apresentado na figura 6.10. no entanto no AISD UNS S32750 somente apresentou-se na interface da junta (figura 6.11). A formação da fase sigma nestes dos aços apresentou-se muito provavelmente durante o resfriamento no 
forno, sendo a taxa de resfriamento não apropriada para estes aços por sua suscetibilidade a formar esta fase por o alto teor de elementos de liga.

(a)
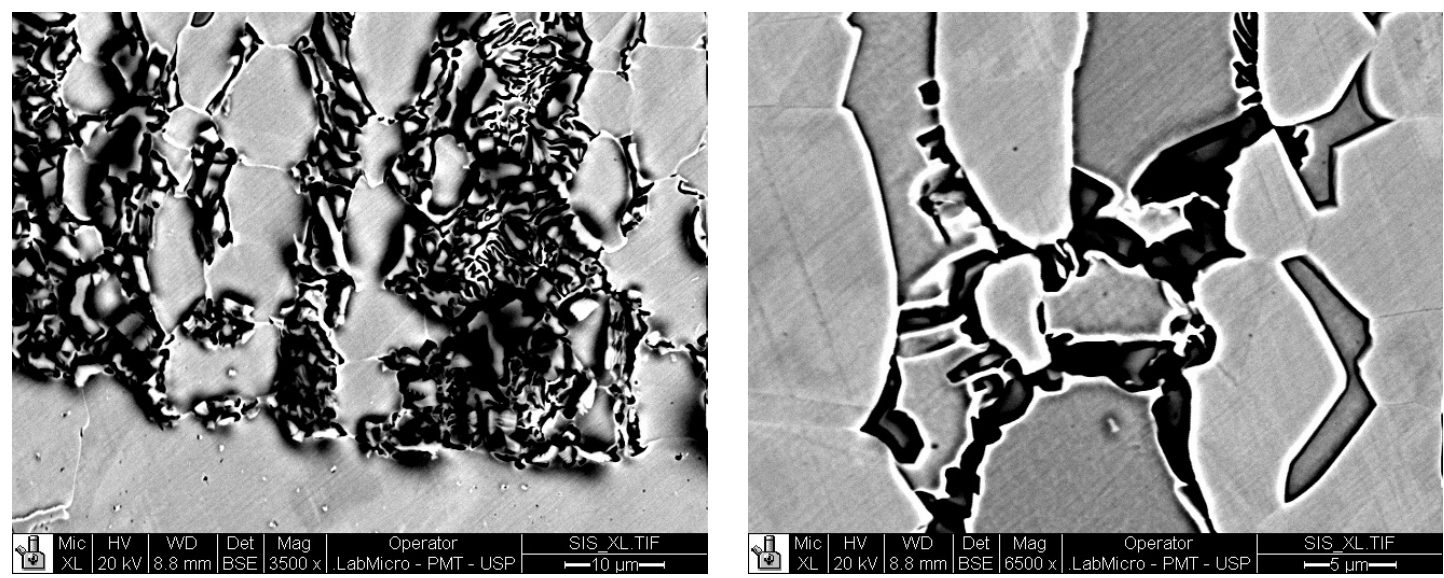

Figura 6.9 - Micrografias da formação da fase sigma no AID UNS S32707 a) perto da interface da junta e b) no metal base.

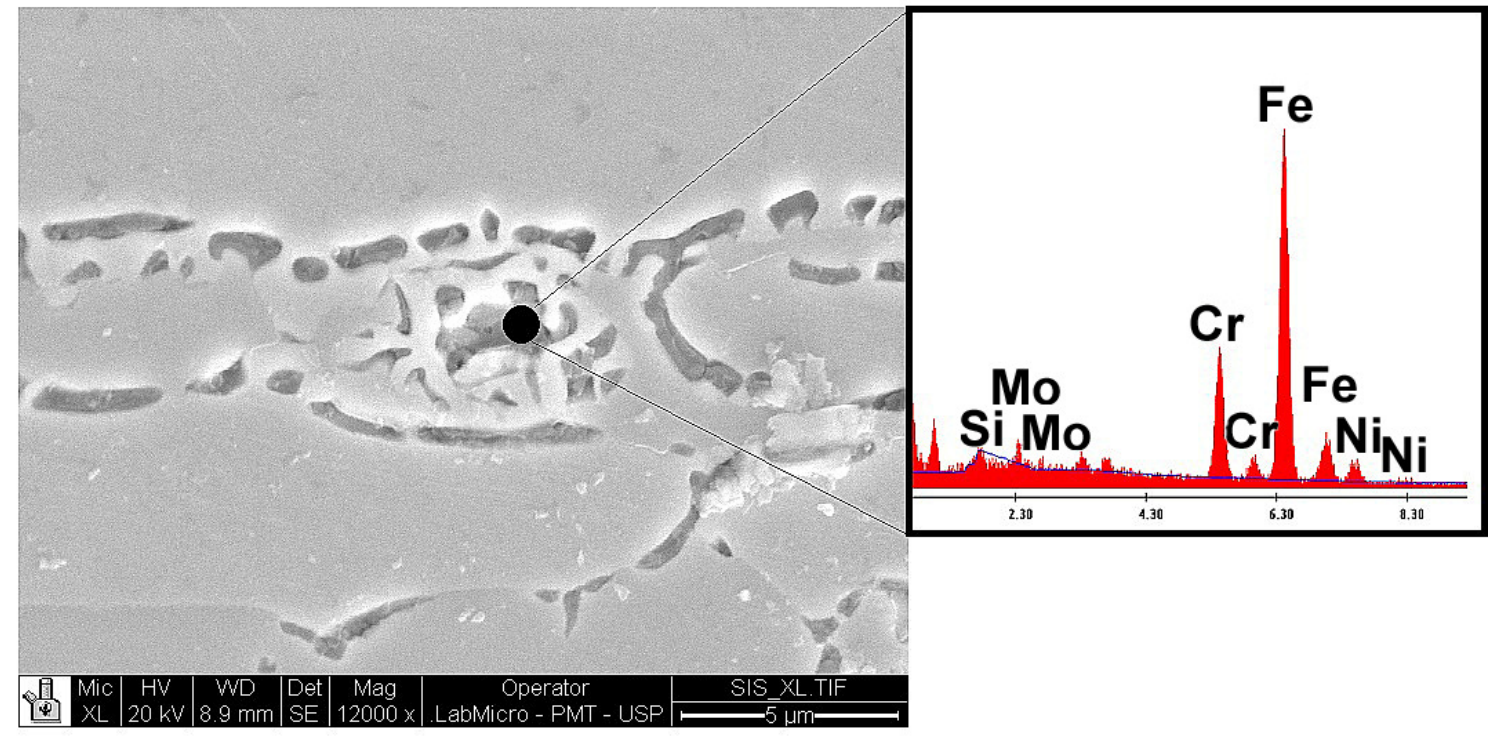

Figura 6.10 - Análise química por EDS da fase identificada da junta brasada para o aço UNS S32750 na interface da junta. 


\section{Conclusões}

Tendo em vista as técnicas experimentais utilizadas pode-se concluir que:

- A junta brasada de AID baixa liga UNS S32101 e UNS S32304 com adição BNi-7 nas condições empregadas não apresentou a formação de fases ricas em fósforo no metal de base, adjacente à região brasada.

- O incremento de tempo de 12 min para 32 min na junta com folga de 0,5 e 0,3 $\mathrm{mm}$ modifica a morfologia e fração volumétrica das fases encontradas, promovendo o aumento da solução sólida $\mathrm{Y}$-Ni, assim como a eliminação de regiões com morfologia eutética na junta brasada. Por outro lado, este incremento de tempo aumenta a dissolução do metal base.

- Na junta com folga de 0,0 mm o tempo de brasagem determinou a quantidade de intermetálicos formados no centro da junta. Sendo menor a formação de intermetálicos para o tempo de brasagem 32 min nos quatro AID.

- Na junta com folga de 0,5 mm o tempo de brasagem determinou a quantidade de fases eutéticas formadas na junta brasada. Apresentando-se nitidamente maior formação de fases eutéticas para o tempo de brasagem de 12 min nos quatro AID.

- Segundo os parâmetros estabelecidos a junta brasada com maior formação de solução sólida rica en níquel ( $\gamma-\mathrm{Ni})$, foi verificada para junta com folga de $0,0 \mathrm{~mm}$ e $32 \mathrm{~min}$ de tempo de brasagem nos AID baixa liga UNS S32101 e UNS S32304.

- O tipo de AID (grau de elementos de liga) determinou a quantidade de fases formadas na região da junta brasada. 


\section{REFERÊNCIAS}

1. ASKELAND, D.R.; PHULÉ, P. P., The science and engineering of materials., 4 ed. California: Brooks/Cole-Thomson Learning, p. 571, 2003.

2. CALLISTER JR., William D. Materials Scince and Engineering: An inttroduction. 6. Ed. New York: Jhon wiley \& Sons, p. 338, 2003. Chapter 11: Applications and processing of metal alloys, p. 332-382.

3. LO, K., H.; SHEK, C. H.; LAI, J. K . L. Recent developments in stainless steels. Materials Science and Engineering R,2009. P. 39-104.

4. FOLKHARD, Erich. Welding Metalurgy of Stainless Steel. Springer-Verlag Wien, New York, 1988

5. CHIAVERINI, Vicente. Aços e ferros fundidos. 7. ed. São Paulo: Associacão Brasileira de Metalurgia e Materiais, 2002. Cap. 23: Aços resistentes à corrosão, p. 381-424.

6. STEEL, S., ASM Internacional. 1994: Materials Park, Ohio.

7. BRESCIANI Filho, E. Selação de materias metálicos. 1986. Cap. 6: Materiais metálicos resistentes à corrosão, $1^{a}$ parte - Aços inoxidáveis, p. 243-267.

8. NILSSON, J.O., Super duplex stainless steels. Materials Science and Technology. V8, n8, pp 685-700, 1992.

9. OLSON, J.; LILJAS, M. 60 years of duplex stainless steel applications. Acom, n.2, p.17-23, 1996.

10.GUNN, R. N., Duplex stainlees steel: Microestructure, Properties and Applications. Abington Publishig, Cambridge, England, 1997. 
11.SOLOMON, H.D.; DEVINE, T. M. Duplex stainless steels - A tale of two phases. In: Conference Duplex Stainless Steel'82, St. Louis-USA, 1982. Proceeding. Ohio. American Society of metals, 1983, p.693-756.

12. HONEYCOMBE, R.W.K., Aços: microestrutura e propriedades: Lisboa: Fundação Calouste Gulbenkian, 1984, Cap. 11: Aços austeníticos, p.301-334.

13. SIEURIN, H.; SANDSTRÖM R.; WESTIN E.M., Fracture Toughness of the lean duplex stainless steel LDX 2101. Metallurgical and Materials Transaction A, 2006. 37A: p. 2975-2981.

14.GAGNEPAIN, J.C., Duplex stainless steels: success story and growth perspectives. Stainless steel world, 2008. 12: p. 31-36.

15. LIOU, H., et al., Effects of alloying elements on the machanical properties and corrosion behaviors of 2205 duplex stainless steel. Journal of Materials Engineering and Performance, 2001. 10(2): p. 231-241.

16. ASM Handbook, vol6, ASM International, 1992

17.WALKER, R.A., Duplex and high alloy stainless steel - Corrosion resistance and weldability. Materials Science and Technology, 1988. 4: p. 78-84.

18. ASTM, A790/A790M-11, Standard Specification for Seamless and Welded Ferritic/Austenitic Stainless Steel Pipe.

19. HERTZMAN, S.; FERREIRA, P. J.; BROLUND, B. An experimental and theoretical study of heat-affected zone austenite reformation in three duplex stainless steels. Metallurgical and Materials Transaction A, 1997. 28A: p. 277285.

20. VORONENKO, Austenitic - Ferritic stainless steels: a state of the art review. Metal Science and Head Treatment, 1997. 39: p. 428-437. 
21. CUNHA, J. A. R.; BRANDI, S.D., Aços inoxidáveis duplex: consideraçoes sobre sua soldagem e processos empregados. Núcleo Inox, 1996: p. 6-8.

22. LIPPOLD, J.C.; LIN, W T; BRANDI, S. D.; VAROL, I.; BAESLACK, W A. Heataffected zone microstructure and properties in comercial duplex stainless steels. In: INTERNATIONAL CONFERENCE DUPLEX STAINLESS STEELS. 1994. Glasgow.

23. UREÑA, A., OTERO, E., UTRILLA, M. V., Weldability of a 2205 duplex stainless steel using plasma arc welding. Journal of Materials Processing Technology, 2007. 182: p. 624-631.

24. PADILHA, A. F.; PLAUT, R. L. Phase transformation and microstructure. In: ALVARES-ARMAS, I.; DEGALLAIX-MOREULI, S. (Ed.) Duplex Stainless Steels. London: ISTE Ltd and John Wiley \& Sons, v. 1, 2009. Cap. 3, p. 115-139.

25. KARLSSON, E., Intermetallic phase precipitation in duplex stainless steels and weld metals metallurgy, influence on properties and welding aspects. Welding in the world, 1999. 43: p. 20-41.

26. CHARLES, J., Structure and mechanical properties of duplex stainless steels. In Conference Duplex Stainless Steel'94, Glasgow-Scotland, 1994. Proceedings. England, TWI, paper K1. 1994.

27.STRADOMSKI, Z.; DYJA, D., Sigma phase precipitation in duplex phase stainless steels. ProQuest, 2009.

28. HERTZMAN, T., Microstructure-property relations of Mo- and W-alloyed Super Duplex Stainless Steel. Materials Science and Technology, 1997. 13: p. 604613.

29. KANG, T.H., Alloying and aging effects on the fatigue crack growth of duplex stainless steels. Materials Science and Engineering A, 1998. 351: p. 192-199. 
30. ROSCOE, C.V.; GRADWELL, K. J.; LORIMER, G. W., Struture/properties relationships in a series of duplex stainless steel In: Conference Stainless steels,84, Göterborg. 1984. Proceedings. London, The Institute of Metals, 1985, p. $563-577$.

31. NORSTROM, L.A., PETTERSSON, S., NORDIN, S., Sigma-Phase Embrittlement in Some Ferritic-Austenitic Stainless Steels. Z. Werkstofftech, 1981. 12: p. 229234.

32. LEE, K.M.; CHO H. S.; CHOID D. C., Effect of isothermal treatment of SAF 2205 duplex stainless steel on migration of $d / g$ interface boundary and growth of austenite. Journal of Alloys and Compounds, 1999. 285: p. 156-161.

33. MONLEVADE, E.F.; GOLDENSTEIN, E.; FALLEIROS, I. G., Intragranular formation of austenite during delta ferferrite decomposition in a duplex stainless steel. Journal of Materials Science, 2010. 45: p. 5089-5093.

34. RAMIREZ A. J., LIPPOID, J.C., BRANDI S. D., The relationship between chromium nitride and secondary austenite precipitation in dupplex stainless steels. Metallurgical and Materials Transaction A, 2003. 34A: p. 1575-1597.

35. SOUTHWICK, P.D.; HONEYCOMBE, R. W. K., Decomposition of ferrite to austenite in 26\%Cr-5\%Ni stainless steel. Metal Science, 1980. 14(7): p. 253.

36. NILSSON, J.O.; LIU, P. Aging at 400-600ㄷ 22Cr-3Mo-8Ni duplex stainless steel and its effect on toughness and microstructure. Materials Science Technology, 1991. 7: p. 853-862.

37.SCHWARTZ, M., Brazing for engineering technologist, Chapman \&.Hall, London, 1995

38. MACHADO, I.G., Soldagem \& técnicas conexas: processos, Editado pelo autor, p. $329-355,1996$ 
39. MARQUES, P.V.; MODENESI, P. J.; BRACARENSE, A. Q., Soldagem fundamentos e tecnologia, Editora UFMG, Belo Horizonte, 2005.

40. FUKUMOTO, A., DOKO, T., Control of erosion in brazing sheet produced by continuous annealing process. Materials Forum 2004. 28: p. 319-325.

41. BRAZING HANDBOOK, $4^{\mathrm{a}}$ ed. American Welding Society, Miami, USA, 1991.

42. AWS, Welding Handbook - Fundamentals of Welding, 5 $5^{\text {a }}$ ed., Massachusetts, 1996.

43. ADAMSON, A.R., Physical chemistry of surfaces. 5 ed. 1990, New York.

44.BRANDI, S.D., Molhamento e espalhamento de ligas Ag-Cu-Ti, Ag-Cu-Ti e AgCu-Ti sobre nitreto de silicio, Tese livre docencia, São Paulo. 1995, p.165

45. HUMPSTON, G., JACOBSON, D. M., Principles of soldering. ASM Int, 2004

46. YOUNG, T., A essay on cohesion of fluids. Philosophical Transactions of the Royal Society, 1805. 95: p. 65-87.

47. IP, S.W., TOGURI, J. M., The equivalency of surface tension, surface energy and surface free energy. Journal of Materials Science, 1994. 29: p. 688-692.

48. DeHOOF, R.T., Thermodynamics in materials science, ed. M.-H.I. EDITIONS. 1993, Singapore.

49. AMERICAN WELDILNG SOCIETY - Specification for filler metals for brazing and braze welding. ANSI/AWS A5.8-92, AWS, 1992.

50. CARVALHO, C. Jr., Estudo da brasabilidade de aço inoxidável duplex UNS S31803. Tese, Escola Politécnica, Universidade de São Paulo, 1999. 
51. MASSALSKI, T.B., SUBRAMAIN, P. R., OKAMOTO, H., KACPRZAK, L., Binary alloy phase diagrams. ASM Int, Metals Park, Ohio, 2nd ed. 1990.

52. MOBLEY, P.R., HOPPIN III, G. S., "Wide-gap" brazing for high-temperature service. Welding Journal, 1961. 40: p. 610-617.

53. SHEWARD, G.E., BELL, G. R., Develoment and evaluation of a Ni-Cr-P brazing filler metal. IN: Source Book on Brazing and Brazing Technology, ASM, 1980: p. 213-221.

54.STRATFORD, G., BATTENBOUGH, A., LEE, L., WEINSTEIN, M., Comparing high-temperature Nickel brazing filler metals. Welding Journal, 2011. 90: p. 5459.

55.ZORC, B., KOSEC, L., Comparison of brazed joints made with BNi-1 and BNi-7 nickel-base brazing alloys. Revista de metalurgia Madrid, 2000. 36: p. 100-107.

56. LUGSCHEIDER, E., KLÖHN, K., LISON, R., Strength of high temperature brazed joints - Influence of brazing parameters. IN: Source Book on Brazing and Brazing Technology, ASM, 1980: p. 154-158.

57. SAKAMOTO, A., FUJIWARA, C., HATTORI, T., SAKAI, S., Optimizing processing variables in high-temperature brazing with nickel-based filler metal. Welding Journal, 1989. 68: p. 63-71.

58.WU, X.W., CHANDEL, R.S., SEOW, H.P., LI, H., Wide gap brazing of stainless steel to nickel - based superalloy. Materials Processing Technology, 2001. 113: p. 215-221.

59. YUAN, X., KANG, C. Y., KIM, M. B., Microstructure and XRD analysis of brazing joint for duplex stainless steel using a Ni-Si-B filler metal. Materials Characterization, 2009. 60: p. 923-931. 
60.PHILIPS, N.R., LEVI, C. G., EVANS, A. G., Mechanisms of microestructure evolution in an austenitic stainlees steel bond generated using a quaternary braze alloy. Metallurgical and Materials Transaction A, 2008. 39A: p. 142-149.

61. LUGSCHEIDER, E., PARTZ, K. D., High temperature brazing of stainless steel with nickel-based filler metals BNi-2, BNi-5, BNi-7. Welding Journal, 1983: p. 160s-164s.

62. ZHANG, X.P., SHI, Y. W., A dissolution model of base metal in liquid brazing filler metal during high temperature brazing. Scripta Materialia, 2004. 50: p. 10031006.

63. LIU, S., OLSON, D. L., MARTIN, G. P., Modeling of brazing processes that use coatings and interlayers. Welding Journal, 1991. 70: p. 207-215

64. OU, C.L., LIAW, D.W., DU, Y. C., SHIUE R. K., Brazing of 422 stainless steel using the AWS classification BNi-2 braze alloy. Journal of Materials Science, 2006. 41: p. 6353-6361.

65. SHIUE, R.K., WU, S. K., HUNG, C. M., Infrared repair brazing of 403 stainless steel with a nickel-based braze alloy. Metallurgical and Materials Transaction A, 2002. 33A: p. 1765-1773.

66.SANTOS, C.R., KUNIOSHI, C., CARVALHO JR., C., BRANDI, S. D., Caraterização Metalográfica de junta brasada de aço inoxidável duplex 2205. Soldagem \& Inspeção, 2007. 12: p. 79-88.

67. TUNG, S.K., LIM, L. C., LAI, M. O., Microstructural evolution and control in BNi-4 brazed joints of nickel 270. Scripta Metallurgica et Materialia, 1995. 33: p. 1253-1259.

68. MacDONALD, W.D., EAGAR, T. W., Isothermal solidification kinetics of difusion brazing. Metallurgical and Materials Transaction A, 1998. 29A|: p. 315-325. 
69. BRANDI, S.D.L., S.; INDACOCHEA, J.E.; XU, R, "Brazeability and Solderability of Engineering Materials". IN: ASM Handbook Volume 6, Welding, Brazing, and Soldering (ASM International), 1993, pp. 617-637. 1993.

70. CULLITY, B.D., Elements of X-ray diffraction, NJ Pretince Hall 2001. 